\title{
PENELITIAN PENGEMBANGAN KEBIJAKAN KONSOLIDASI TANAH VERTIKAL
}

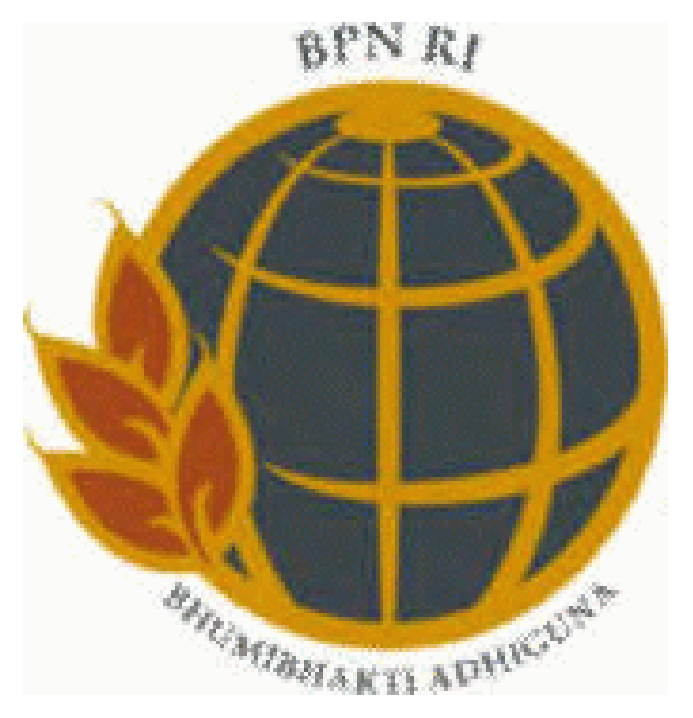

Trie Sakti SH CN

\section{BADAN PERTANAHAN NASIONAL PUSAT PENELITIAN DAN PENGEMBANGAN \\ 2010}




\section{KATA PENGANTAR}

Segala puji dan Syukur dipanjatkan kepada Allah SWT karena dengan perkenanNya maka Laporan Akhir Penelitian Pengembangan Kebijakan Konsolidasi Tanah Vertikal dapat diselesaikan pada waktunya.

Kepadatan penduduk di sejumlah kota besar di Indonesia semakin meningkat dari tahun ke tahun sedangkan ketersediaan tanah diperkotaan terbatas dan kondisi ekonomi masyarakat yang rendah, sehingga tanpa penataan lingkungan pemukiman akan mengakibatkan timbulnya kantong-kantong kumuh di wilayah perkotaan tersebut. Oleh karena itu sudah saatnya untuk melakukan pembangunan perumahan yang memanfaatkan ruang ke atas secara vertikal untuk memenuhi kebutuhan perumahan diperkotaan dan optimalisasi penggunaan dan pemanfaatan tanah. Dengan konsolidasi tanah maka penggusuran dapat dihindarkan karena prinsip dasarnya adalah melibatkan partisipasi masyarakat dalam membangun dan menerima hasil pembangunan. Konsolidasi Tanah sebagai salah satu konsep penataan dan pembangunan lingkungan pemukiman mempunyai beberapa manfaat, yaitu menata dan mengatur kembali daerah yang tidak teratur menjadi teratur dengan dilengkapi prasarana dan fasilitas lingkungan yang memadai sesuai keperluan.

Dari hasil penelitian diketahui bahwa belum ada satupun daerah yang sudah melaksanakan konsolidasi tanah secara vertikal, namun ditemukan model pembangunan rumah susun yang konsepnya mendekatidengan konsep konsolidasi tanah secara vertikal. Hal ini dapat diambil sebagai rujukan dalam pengembangan konsep Konsolidasi Tanah vertikal di Indonesia. Mengingat peraturan yang berlaku saat ini belum mendukung sepenuhnya pelaksanaan pembangunan rumah susun melalui konsolidasi tanah secara vertikal maka diperlukan peraturan yang secara khusus mengatur mengenai konsolidasi tanah secara vertikal dengan mengkombinasikan ketentuan yang merupakan azas prinsip dalam konsolidasi sesuai dengan Perkaban No.4 tahun 1991 dengan ketentuan UURS yang mengatur sistem pembangunan dan pemilikan rumah susun.

Kami berharap hasil penelitian ini dapat memberikan konstribusi bagi penyelesaian Perumahan dan permukiman dimasa yang akan datang, dan jika memungkinkan untuk ditindak lanjuti dengan suatu kebijakan pertanahan.

Akhirnya penulis mengharapkan adanya usulan, saran ataupun kritik yang dapat lebih menyempurnakan laporan penelitian ini dan memberikan solusi yang tepat terhadap penyelesaian masalah perumahan dan pemukiman saat ini. Wassalam.

Jakarta, Desember 2010 


\section{DAFTAR ISI}

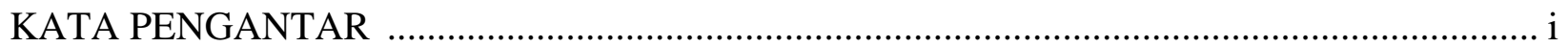

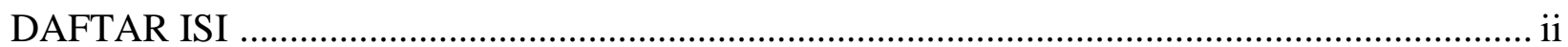

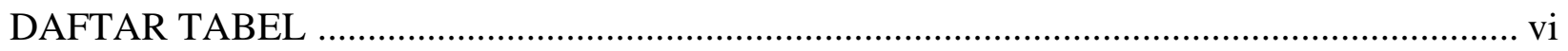

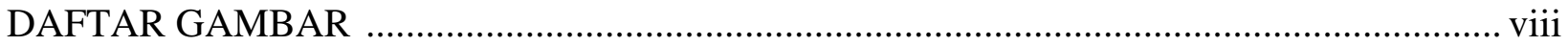

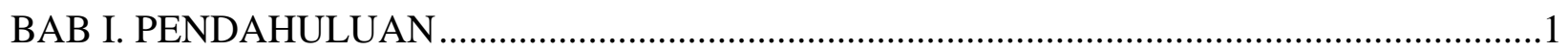

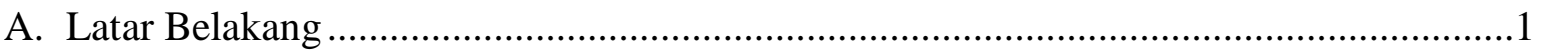

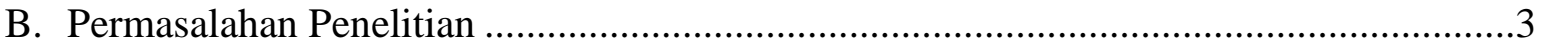

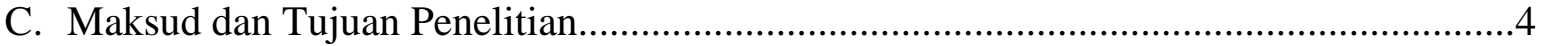

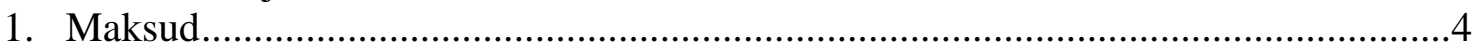

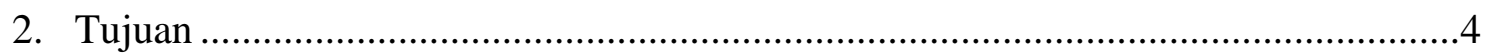

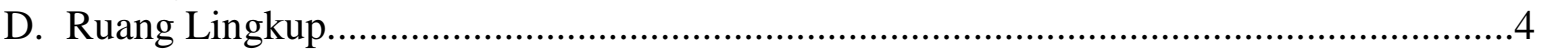

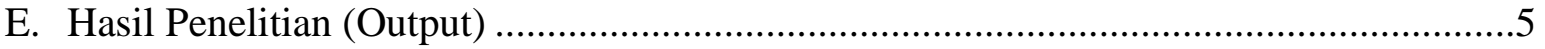

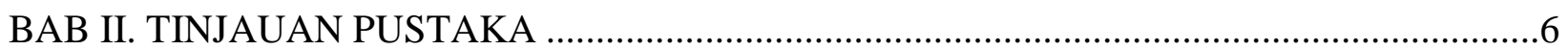

A. Sistim Pemilikan Rumah Susun Di Indonesia ........................................................6

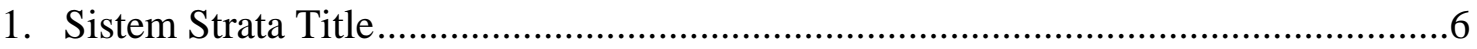

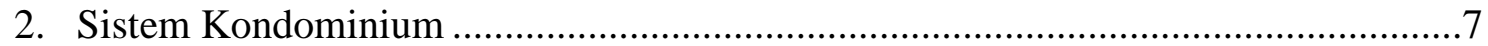

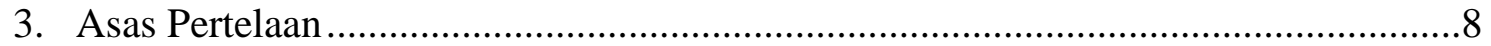

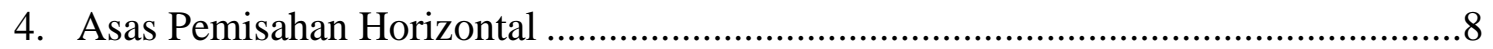

B. Mekanisme Konsolidasi Tanah Di Indonesia ............................................................ 9

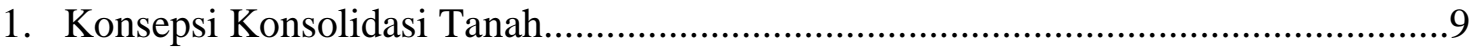

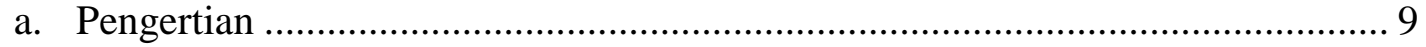

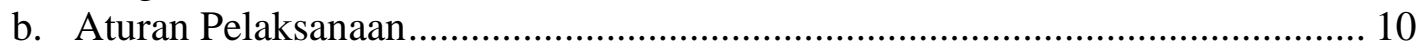

1) Undang-undang Dasar Negara RI 1945 ................................................10

2) Undang-undang Nomor 5 Tahun 1960 tentang Peraturan Dasar Pokokpokok Agraria; ..................................................................................11

3) Undang-Undang No. 16 Tahun 1985 tentang Rumah Susun .....................11

4) Undang-undang Nomor 4 Tahun 1992 tentang Perumahan dan

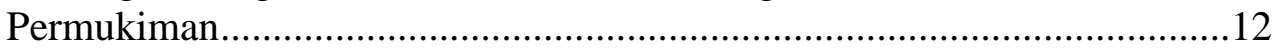

5) Undang-Undang Nomor 28 Tahun 2002 tentang Bangunan Gedung .........12

6) Undang-undang Nomor 26 Tahun 2007 tentang Penataan Ruang ..............13

7) Peraturan Pemerintah No. 16 tahun 2004 tentang Penatagunaan Tanah.....13

8) Undang-undang Nomor 32 tahun 2004 tentang Pemerintahan Daerah.......14

9) Peraturan Presiden Nomor 10 Tahun 2006 tentang Badan Pertanahan

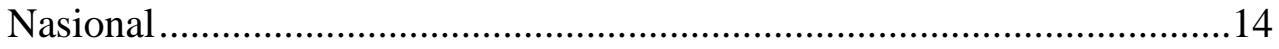

10) Keputusan Presiden Nomor 22 tahun 2006 tentang Tim Koordinasi Percepatan Pembangunan Rumah Susun di Kawasan Perkotaan................14

11) Peraturan KaBPN Nomor 4 Tahun 1991 tentang Konsolidasi Tanah.........15

12) Peraturan KaBPN Nomor 3 Tahun 2006 tentang Organisasi Dan Tata Kerja Badan Pertanahan Nasional Republik Indonesia............................15

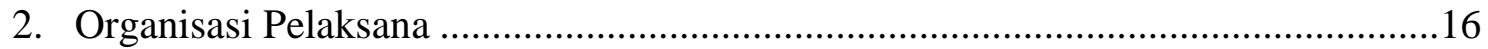

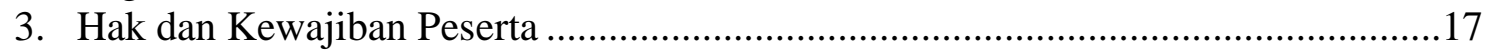


4. Prosedur Pelaksanaan..............................................................................................17

5. Potensi Implikasi Penerapan Metoda Konsolidasi Tanah Bagi Pengembang Perumahan Real Estat ......................................................................................21

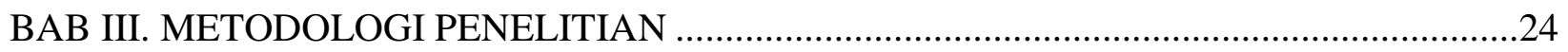

A. Lokasi Penelitian.....................................................................................................24

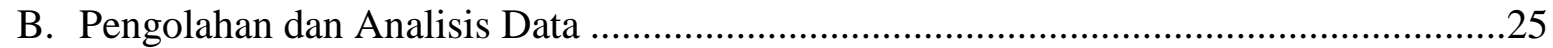

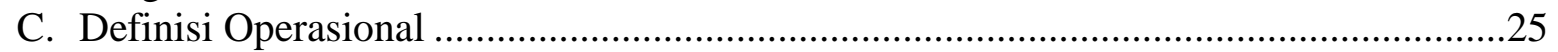

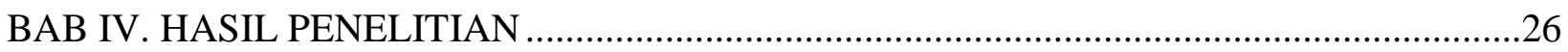

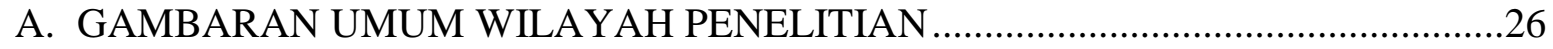

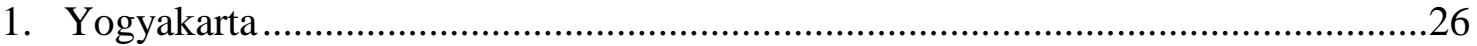

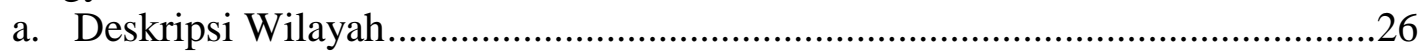

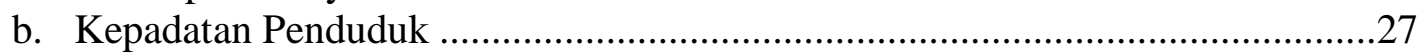

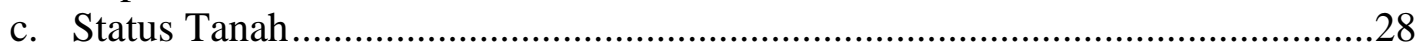

d. Penggunaan Tanah ..................................................................................28

e. Pelaksanaan Konsolidasi tanah ........................................................................

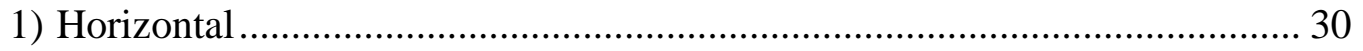

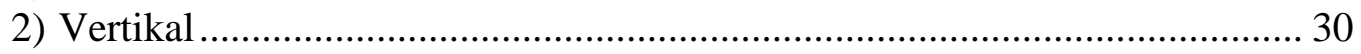

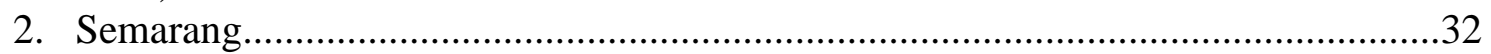

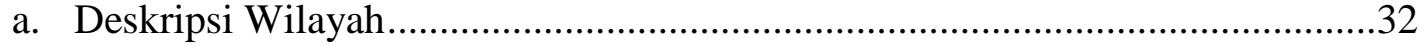

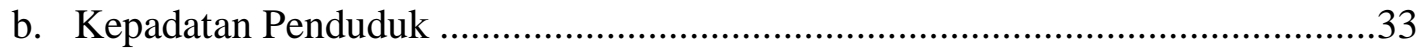

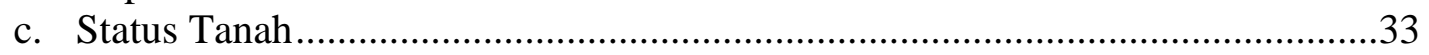

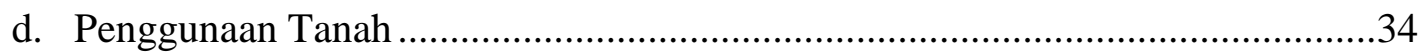

e. Pelaksanaan Konsolidasi Tanah.......................................................................34

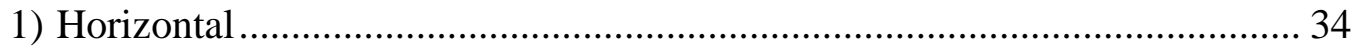

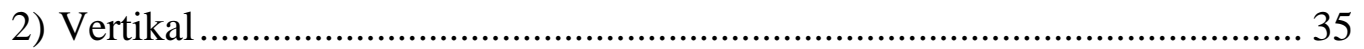

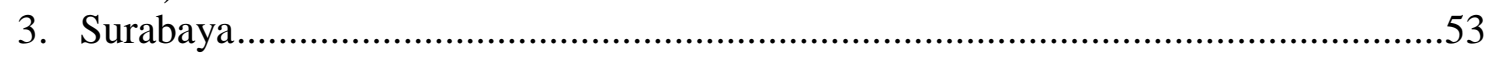

a. Deskripsi Wilayah........................................................................................53

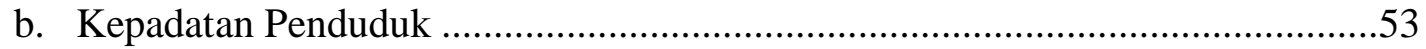

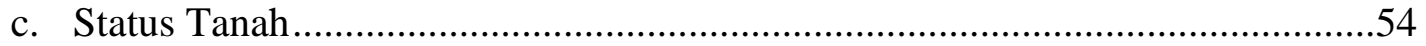

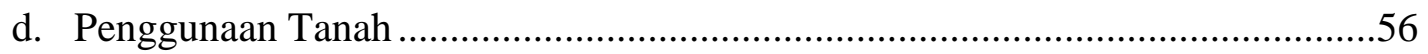

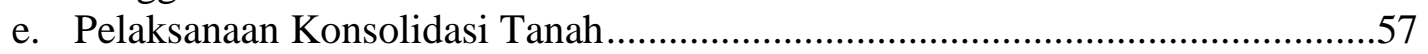

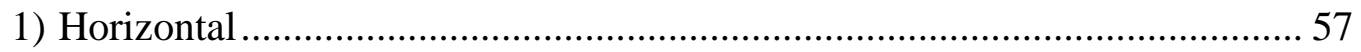

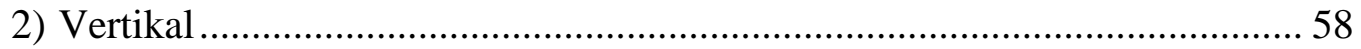

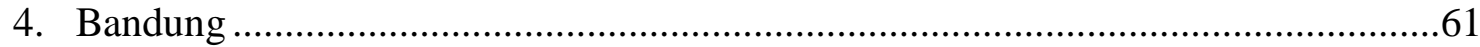

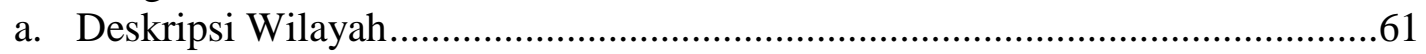

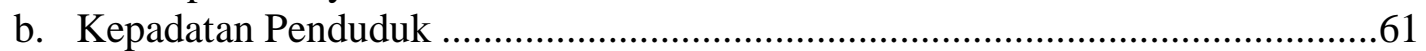

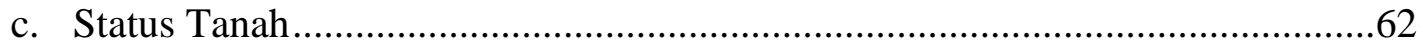

d. Penggunaan Tanah ....................................................................................62

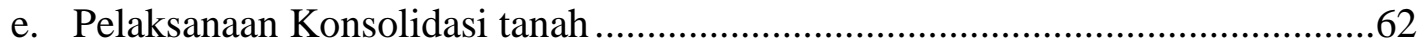

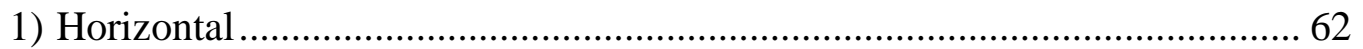

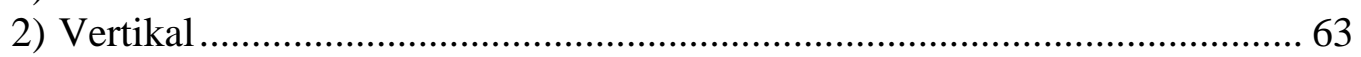

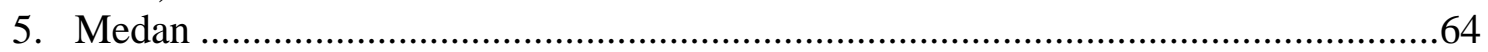

a. Deskripsi Wilayah...................................................................................64

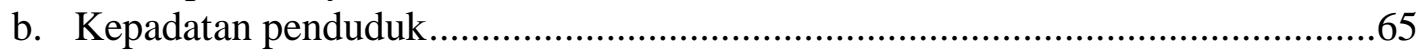


c. Status Tanah..................................................................................................66

d. Penggunaan Tanah ........................................................................................66

e. Pelaksanaan Konsolidasi tanah ...................................................................67

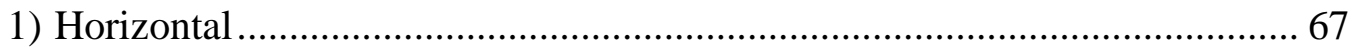

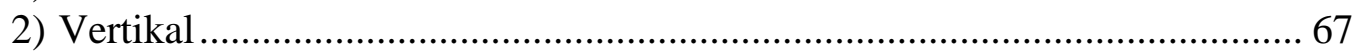

6. Palembang ..................................................................................................69

a. Deskripsi Wilayah........................................................................................69

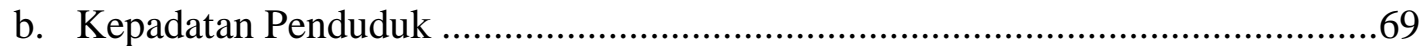

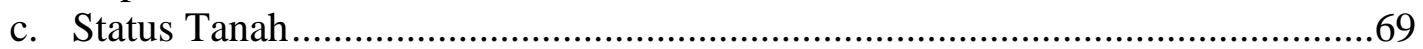

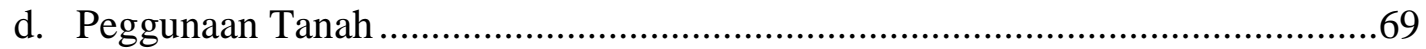

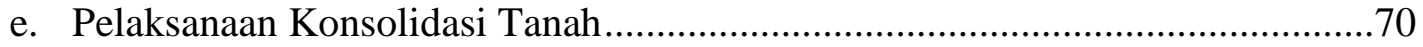

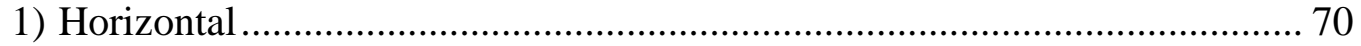

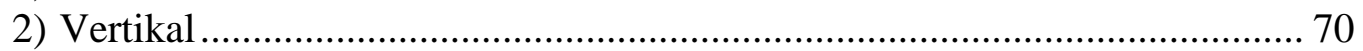

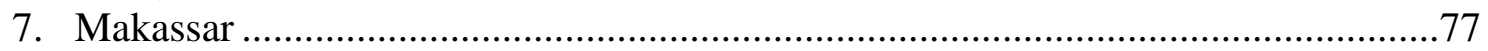

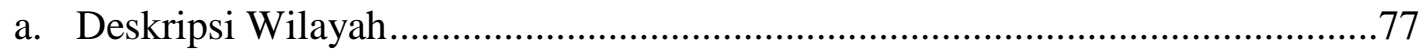

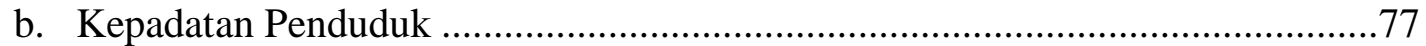

c. Penguasaan dan Pemilikan Tanah...................................................................78

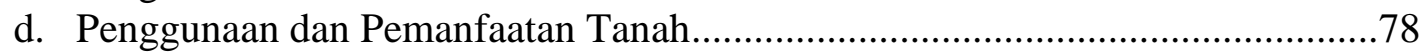

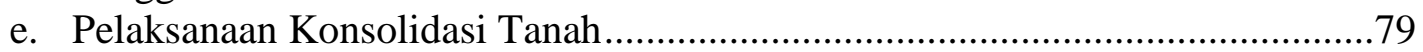

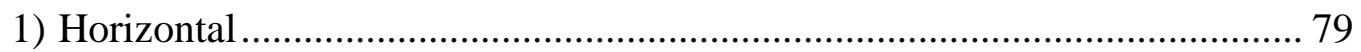

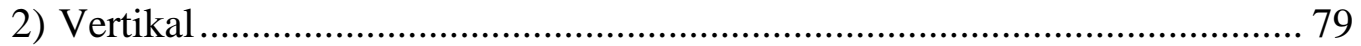

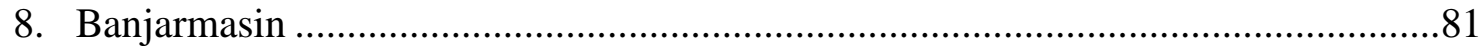

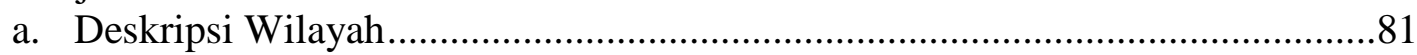

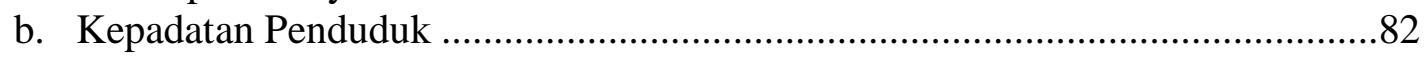

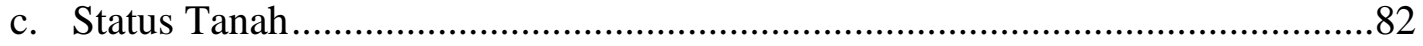

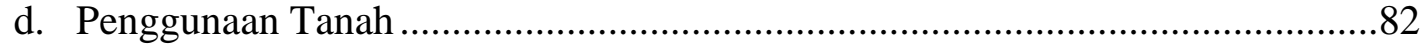

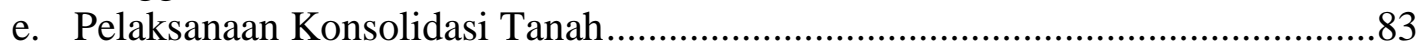

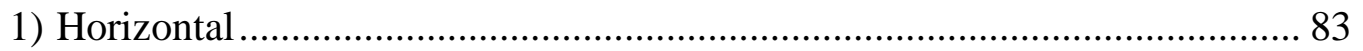

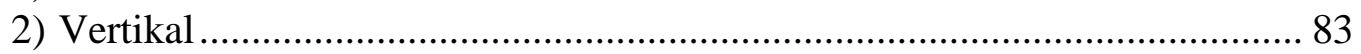

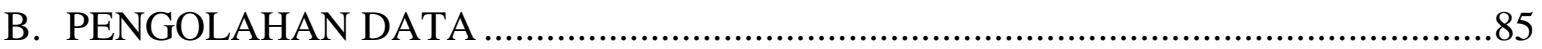

1. Gambaran Kepadatan Penduduk dan Pendapatan Perkapita di Lokasi Sampel

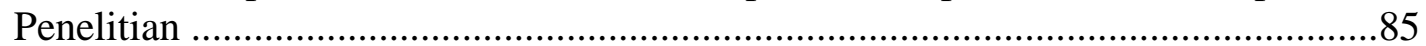

2. PDRB Perkapita dan Pertumbuhan Ekonomi di Lokasi Sampel Penelitian. .............87

3. Status Tanah di Lokasi Sampel Penelitian............................................................90

4. Penggunaan Tanah di Lokasi Sampel Penelitian..................................................92

5. Pelaksanaan Konsolidasi Tanah di Lokasi Sampel Penelitian..................................93

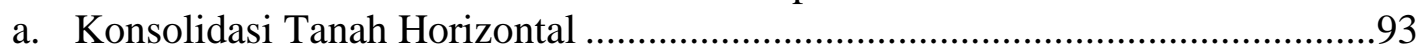

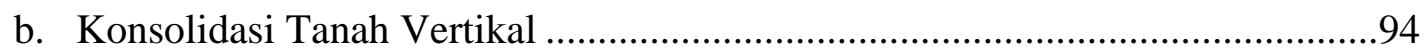

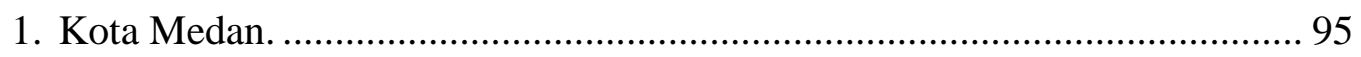

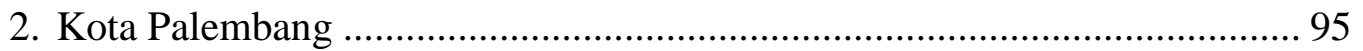

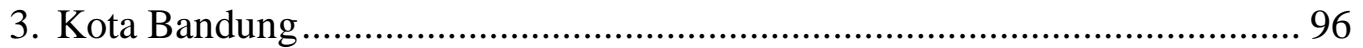

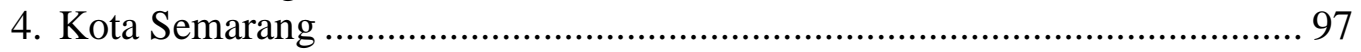

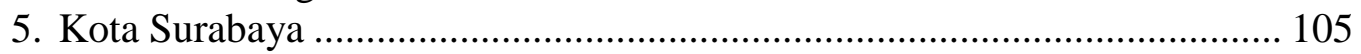

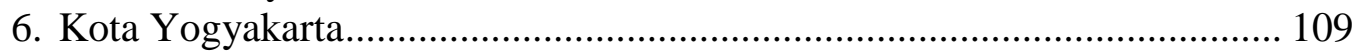

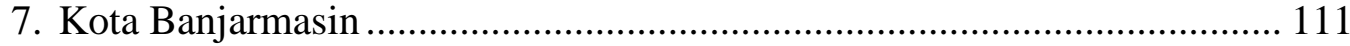


BAB V. PEMBAHASAN

A. Sejauhmana konsep konsolidasi tanah dengan pendekatan pembangunan perumahan vertikal layak dilaksanakan/dikembangkan secara fisik, ekonomi dan sosial untuk menata kembali penguasaan, pemilikan, penggunaan dan pemanfaatan tanah di wilayah perkotaan

1. Penyelenggaraan Konsolidasi Tanah Perkotaan yang telah dilaksanakan di lokasi sampel penelitian

2. Landasan hukum pelaksanaan konsolidasi tanah Vertikal di lokasi sampel penelitian

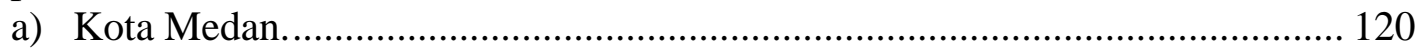

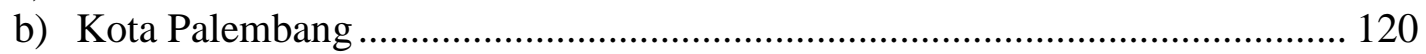

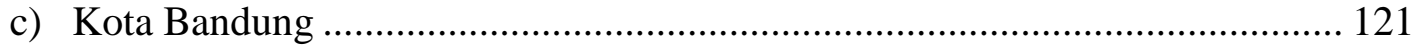

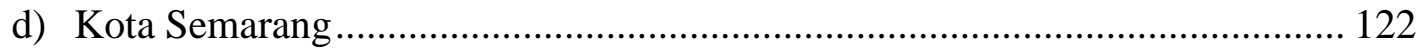

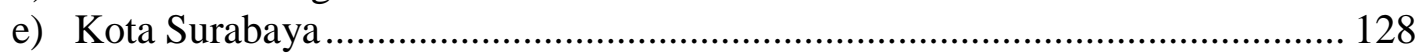

f) Kota Yogyakarta .................................................................................. 132

B. Apakah peraturan perundang-undangan yang ada dapat mendukung pelaksanaan

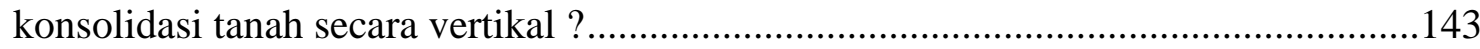

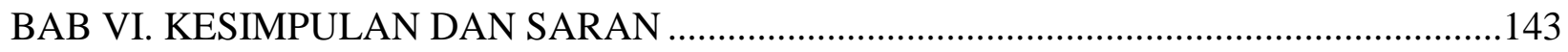

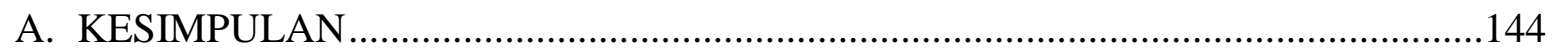

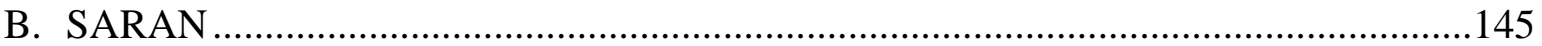

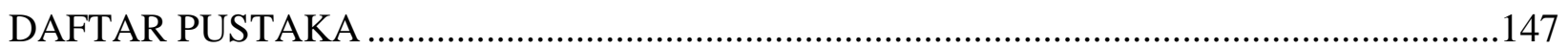




\section{DAFTAR TABEL}

Tabel 1. Lokasi Penelitian Konsolidasi Tanah Vertikal ........................................................24

Tabel 2. Unit Penelitian dan Jumlah Responden ....................................................................24

Tabel 3. Kepadatan Penduduk Kota Yogyakarta ...............................................................27

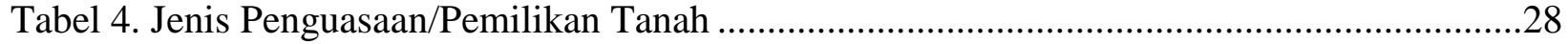

Tabel 5. Penggunaan Lahan menurut Kecamatan di Kota Yogyakarta 2008 .............................29

Tabel 6. Lokasi Konsolidasi Tanah Perkotaan di Prop. DI Yogyakarta .....................................30

Tabel 7. Lokasi Pembangunan Rusunawa di Kota Yogyakarta................................................31

Tabel 8. Banyaknya Penduduk di Kota Semarang.................................................................33

Tabel 9. Luas dan jumlah bidang/peserta dalam pelaksanaan konsolidasi tanah perkotaan di Kota Semarang tahun 2009...............................................................................34

Tabel 10. Lokasi Pembangunan Rusun/Rusunawa di Kota Semarang, Propinsi Jawa Tengah....35

Tabel 11. Nilai kompensasi tanah dan bangunan masyarakat penghuni ....................................36

Tabel 12. Penghuni/Pemilik Rusun Pekunden, Kota Semarang .............................................51

Tabel 13. Penghuni/Penyewa Rusun Pekunden, Kota Semarang ............................................52

Tabel 14. Kepadatan Penduduk Kota Surabaya ..................................................................54

Tabel 15. Penguasaan dan Pemilikan Tanah di Kota Surabaya .............................................56

Tabel 16. Luas Penggunaan Lahan Per Kecamatan di Kota Surabaya Tahun 2008 ...................56

Tabel 17. Lokasi Konsolidasi Tanah Perkotaan di Prop. Jawa Timur (2005 - 2010) .................57

Tabel 18. Penguasaan dan Pemilikan Tanah di Kota Bandung ...............................................62

Tabel 19. Jenis Penggunaan Tanah di Kota Bandung.......................................................62

Tabel 20. Lokasi Konsolidasi tanah di Kota Bandung .....................................................63

Tabel 21. Lokasi rusunawa di Kota Bandung .................................................................63

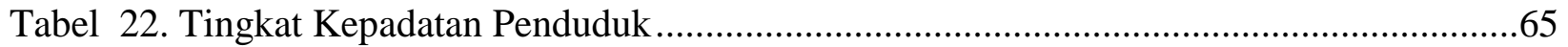

Tabel 23. Penguasaan dan Pemilikan Tanah di Kota Medan....................................................66

Tabel 24. Lokasi Konsolidasi Tanah Perkotaan di Prop. Sumatera Utara.................................67

Tabel 25. Luas Wilayah Kota Palembang..........................................................................69

Tabel 26. Lokasi Konsolidasi Tanah Perkotaan di Prop. Sumatera Selatan tahun 2009 ..............70

Tabel 27. Presentase Penduduk dan Kepadatan Penduduk Menurut Kecamatan

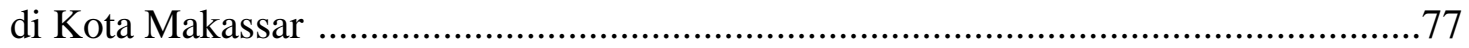

Tabel 26. Penguasaan dan Pemilikan Tanah Kota Makassar .....................................................78

Tabel 27. Jenis Penggunaan Tanah di Kota Makassar.............................................................78

Tabel 28. Pelaksanaan Konsolidasi Tanah Prov. Sulawesi Selatan ..........................................79

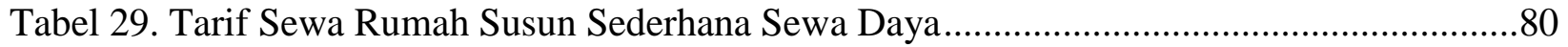

Tabel 30. Kepadatan Penduduk Kota Banjarmasin .............................................................82

Tabel 31. Luas Penggunaan Lahan Per Kecamatan di Kota Banjarmasin Tahun 2008 ...............83

Tabel 32. Status dan Pemilikan Tanah lokasi Konsolidasi Tanah ...........................................83

Tabel 33. Gambaran Kepadatan Penduduk dan Pendapatan Perkapita di Lokasi Sampel

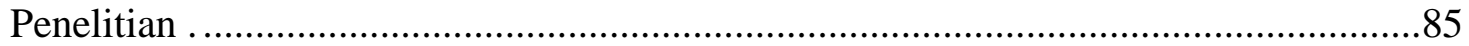

Tabel 34. Gambaran Kepadatan Penduduk dan Pendapatan Perkapita di Kota Sampel

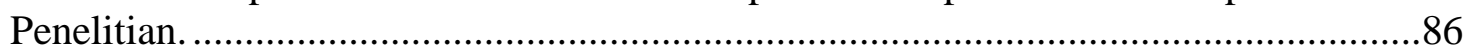

Tabel 35. PDRB Perkapita dan Pertumbuhan Ekonomi di Lokasi Sampel Penelitian. ................87

Tabel 36. PDRB Perkapita dan Pertumbuhan Ekonomi di Kota Sampel Penelitian ..................89

Tabel 37. Status Tanah di Lokasi Sampel Penelitian (dlm jumlah bidang)............................90 
Tabel 38. Luas Penggunaan Tanah di Kota Sampel Penelitian

Tabel 39. Pelaksanaan Konsolidasi Tanah Horizontal di Lokasi Sampel Penelitian

Tabel 40. Pelaksanaan Konsolidasi Tanah dengan pendekatan pembangunan secara vertikal di Lokasi Sampel Penelitian

Tabel 41. Lokasi Pembangunan Rusun/Rusunawa di Kota Semarang, Propinsi Jawa Tengah.....97

Tabel 42. Rencana lokasi konsolidasi tanah dengan pembangunan vertikal di Kota Surabaya ..108

Tabel 43. Pembangunan Rusun Sewa di Kota Yogyakarta :

Tabel 44. Pelaksanaan pembangunan perumahan secara vertikal di Lokasi Sampel Penelitian 119

Tabel 45. Rencana lokasi konsolidasi tanah dengan pembangunan vertikal di Kota Surabaya ..131 


\section{DAFTAR GAMBAR}

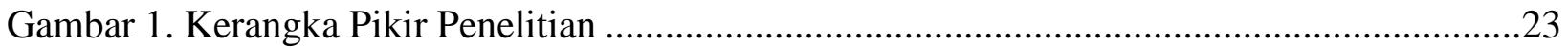

Gambar 2. Sketsa Rusun Pekunden tampak dari depan...........................................................44

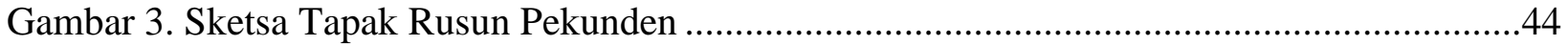

Gambar 4. Fasos \& Fasum Rusun Pekunden.........................................................................45

Gambar 5. Denah Lantai Dasar Rusun Pekunden.................................................................45

Gambar 6. Denah Lantai 2 Rusun Pekunden ..............................................................................46

Gambar 7. Denah Lantai 3 \& 4 Rusun Pekunden ..................................................................46

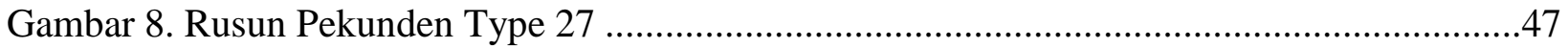

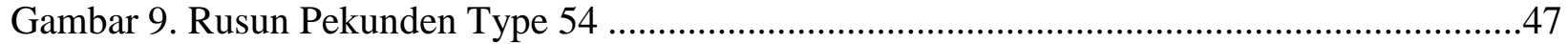

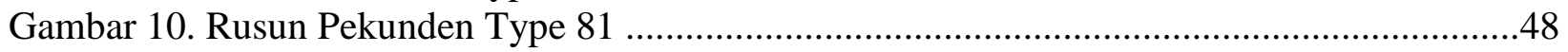

Gambar 11. Rusun Pekunden tampak dari depan ..................................................................48

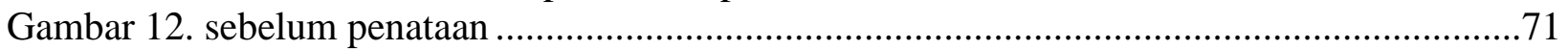

Gambar 14. Pemanfaatan fasilitas umum/taman bermain untuk tempat parkit dan ruang usaha ..74

Gambar 15. Pemanfaatan fasilitas bersama untuk bangunan di lantai I dan lahan terbuka yang dibiarkan menjadi semak belukar dan tidak terawat (kumuh). ................................74

Gambar 16. Pemanfaatan fasilitas bersama di lantai I untuk ruang usaha pribadi .......................75

Gambar 17. Pemanfaatan fasilitas bersama di lantai I untuk rumah makan .............................75

Gambar 18. Rumah Susun Sederhana Sewa (Rusunawa) Daya ...........................................8

Gambar 19. Rusunawa Ganda Maghfirah di Kota Banjarmasin.............................................84

Gambar 20. Grafik Kepadatan Penduduk di Lokasi Sampel Penelitian . ...................................86

Gambar 21. Grafik Kepadatan Penduduk di Kota Sampel Penelitian . ....................................87

Gambar 22. Grafik PDRB Perkapita di Lokasi Sampel Penelitian .........................................88

Gambar 23. Grafik Pertumbuhan Ekonomi di Lokasi Sampel Penelitian . ...............................88

Gambar 24. Grafik PDRB Perkapita di Lokasi Sampel Penelitian ............................................89

Gambar 25. Grafik Pertumbuhan Ekonomi di Lokasi Sampel Penelitian. .................................90

Gambar 26. Grafik Status Tanah di Lokasi Sampel Penelitian (dlm jumlah bidang)................91

Gambar 27. Grafik Penggunaan Tanah di Lokasi Penelitian..................................................92 


\section{BAB I \\ PENDAHULUAN}

\section{A. Latar Belakang}

Perumahan dan permukiman merupakan salah satu kebutuhan dasar manusia, yang juga mempunyai peran sangat strategis sebagai pusat pendidikan keluarga, persemaian budaya, dan peningkatan kualitas generasi mendatang. Permasalahan perumahan dan permukiman tidak dapat dipandang sebagai permasalahan fungsional dan fisik semata, tetapi lebih kompleks lagi sebagai permasalahan yang berkaitan dengan dimensi kehidupan bermasyarakat yang meliputi aspek sosial, ekonomi, budaya, teknologi, ekologi maupun politik.

Pasal $28 \mathrm{H}$ ayat (1) UUD 1945 menyebutkan bahwa setiap orang berhak hidup sejahtera lahir dan batin, bertempat tinggal dan mendapat lingkungan hidup yang baik dan sehat serta berhak memperoleh pelayanan kesehatan. Dalam kaitan dengan pasal tersebut, maka Pemerintah telah mengeluarkan Peraturan Presiden Nomor 7 tahun 2005 tentang Rencana Pembangunan Jangka Menengah (RPJM) 2004-2009, dimana salah satu agenda pentingnya adalah upaya percepatan pembangunan infrastruktur, termasuk didalamnya masalah pembangunan Perumahan dan Pemukiman guna memenuhi kebutuhan masyarakat akan papan yang layak dalam lingkungan yang sehat.

Kebijakan percepatan pembangunan perumahan dan pemukiman sangat penting mengingat kebutuhan perumahan yang layak huni semakin hari semakin meningkat terutama diwilayah perkotaan. Wilayah perkotaan tumbuh dan berkembang sebagai tempat pemusatan penduduk demikian pula dengan sarana ikutan/aktifitasnya di muka bumi ini sangat dipengaruhi oleh laju pertumbuhan penduduknya, baik disebabkan adanya pertambahan penduduk secara alamiah (kelahiran), urbanisasi maupun migrasi. Menurut data Biro Pusat Statistik (BPS), bahwa penduduk perkotaan pada tahun 1970 berjumlah 20,77 juta jiwa atau \pm 17,00 \% dari total penduduk Indonesia dan meningkat menjadi $\pm 87,58$ juta jiwa $( \pm 41,80 \%)$ pada tahun 2000. Jumlah penduduk perkotaan tersebut terus meningkat setiap tahun, dimana menurut proyeksi yang dibuat Ananta dan Anwar (1995) pada tahun 2010 diperkirakan 116,48 juta jiwa $( \pm 49,55$ $\%)$ dan di asumsikan meningkat menjadi $\pm 140,31$ juta jiwa $( \pm 55,19 \%)$ pada tahun 2020 .

Dinamika laju pertumbuhan penduduk perkotaan di atas membawa konsekuensi logis adanya tuntutan penambahan kebutuhan ruang untuk mewadahi segala aktivitas kehidupan dan usaha masyarakat tersebut termasuk dukungan pengadaan fasilitas dan utilitas kota berupa prasarana jalan, pemukiman/perumahan dan sebagainya. Kondisi ini menimbulkan ketidakseimbangan antara ketersediaan tanah dengan kebutuhan yang diperlukan untuk perluasan ruang bagi warga kota.

Dengan luas wilayah perkotaan yang relatif tetap, namun pada sisi lain kebutuhan ruangnya (tanah) secara garis lurus terus menerus meningkat. Adanya peningkatan kebutuhan ruang tersebut menimbulkan permasalahan dalam bidang pertanahan dimana terjadi ketidakseimbangan antara ketersediaan dengan kebutuhan tanah yang diperlukan untuk perluasan ruang kota. Fenomena tersebut menimbulkan tumbuh dan berkembangnya penguasaan, pemilikan dan pemanfaatan tanah secara tidak sah (liar), lingkungan kumuh (slum area), dan timbulnya spekulan tanah, karena harga tanah selalu naik secara tidak wajar dan lain sebagainya. 
Lebih lanjut keadaan ini seringkali menyebabkan upaya-upaya pemerintah atau pemerintah kota (Pemko) untuk membenahi atau meremajakan lingkungan pemukiman kumuh di wilayah perkotaan mengalami kesulitan atau bahkan kegagalan, terutama dalam membebaskan tanahtanah yang diperlukan untuk pembangunan tersebut.

Disisi lain, saat ini kecenderungan perkembangan perumahan di perkotaan terus menyebar ke arah horisontal, sehingga kota terus berkembang menjadi megapolitan. Namun perkembangan perkotaan tersebut tidak diimbangi dengan pemerataan antara komposisi perumahan dengan sarana dan prasarana permukiman, sehingga apa yang kita lihat adalah kecenderungan masyarakat yang tinggal di pinggiran kota setiap harinya, harus ulang alik yang sangat melelahkan karena tempat kerja yang terkonsentrasi di perkotaan. Kondisi demikian menimbulkan pergerakan manusia setiap harinya pada pagi hari dari pinggiran ke perkotaan dan pada sore hari dari perkotaan ke pinggiran, rata-rata waktu yang diperlukan oleh masyarakat diperjalanan mencapai paling sedikit 3 - 4 jam perhari. ${ }^{1}$

Penyediaan tanah merupakan masalah utama pembangunan perumahan sebagai salah satu pemenuhan kebutuhan hak dasar rakyat. Terbatasnya tanah di perkotaan menyebabkan pemerintah kota dituntut untuk dapat memanfaatkan tanah secara efisien dengan meningkatkan intensitas penggunaannya. Langka dan mahalnya tanah di daerah perkotaan menyebabkan sulitnya Pemerintah untuk menyediakan perumahan bagi rakyat. Selain itu masyarakat enggan menjual tanahnya, oleh karena itu diperlukan partisipasi masyarakat dengan pembangunan tanpa menggusur yaitu melalui konsolidasi tanah, namun karena terbatasnya tanah maka harus dilakukan optimalisasi penggunaan dan pemanfaatan tanah, sehingga konsolidasi tanah dilakukan secara vertikal. Oleh sebab itu sudah saatnya Pemerintah Indonesia menyelenggarakan konsolidasi tanah vertikal tersebut.

Selama ini Pemerintah atau Pemerintah Kota telah memanfaatkan dan mengembangkan konsep pembangunan lingkungan pemukiman yang terpadu dengan melibatkan partisipasi masyarakat pemilik tanahnya. Salah satu konsep pembangunan itu adalah konsolidasi tanah (land consolidation) atau untuk perumahan dikenal dengan istilah konsolidasi tanah perkotaan (urban land consolidation). Konsolidasi tanah ini merupakan konsep pembangunan lingkungan pemukiman yang terpadu, karena selain menata kembali penguasaan, pemilikan dan penggunaan tanahnya secara optimal, tertib dan teratur, serta melibatkan partisipasi masyarakat pemilik tanahnya. Pelaksanaannya didasarkan pada prinsip "membangun tanpa menggusur" dengan mengikut sertakan partisipasi masyarakat dalam bentuk "dari, oleh dan untuk mereka sendiri" .

Konsep konsolidasi tanah perkotaan dengan pendekatan pemanfaatan ruang secara horizontal (hamparan) sudah banyak diterapkan di Indonesia, namun dengan model pembangunan yang memanfaatkan ruang ke atas (vertikal) belum banyak dikenal. Konsep konsolidasi tanah vertikal ini dirasakan semakin penting mengingat permasalahan ketersediaan tanah yang ada di perkotaan terutama di kota-kota besar semakin terbatas untuk penyediaan tempat tinggal bagi warganya serta fasilitas lainnya, selain mengikutsertakan partisipasi masyarakat dalam menata kembali lingkungan pemukimannya melalui konsolidasi tanah, juga

1 Menteri Negara Perumahan Rakyat Republik Indonesia, Keynote Speech Seminar Pengembangan Rumah Susun, Prospek, Tantangan Dan Permasalahannya, Jakarta, 2007. 
harus diprioritaskan menerapkan pembangunan yang mampu menghemat pemanfaatan tanahnya dengan pendekatan pembangunan perumahan secara vertikal.

Sementara itu program percepatan pembangunan Rumah Susun yang sedang digalakkan oleh Pemerintah terutama pada 10 kawasan perkotaan, yakni Medan, Batam, Palembang, Jabodetabek, Bandung, Semarang, Yogyakarta, Surabaya, Banjarmasin, dan Makassar, menunjukkan bahwa pasokan penyediaan Rumah Susun Sederhana Sewa (Rusunawa) 2 tahun terakhir hanya mencapai pasokan sebanyak 56,5 twinblock dengan kapasitas 4.300 sarusun selama 2 tahun atau hanya sebesar $18 \%$ dari rata-rata sasaran tahunan yang ditetapkan dalam RPJMN sebanyak 12.000 sarusun. Sedangkan Rumah Susun Sederhana Milik (Rusunami) dari total target RPJMN sebanyak 25.000 sarusun melalui mekanisme pasar, pasokannya hanya mencapai 144 sarusun, atau hanya mencapai 1,44 \% selama 2 tahun. Hal ini dikarenakan mahalnya harga tanah di pusat kota untuk pembangunan perumahan serta keterbatasan pasokan Rusun dikarenakan beberapa permasalahan mendasar berupa: beban biaya yang tinggi dalam pengurusan proses perijinan (ijin pemanfaatan ruang, ijin lokasi, sertifikasi tanah, dan ijin mendirikan bangunan); beban pajak; keterbatasan dukungan prasarana, sarana, dan utilitas (PSU); serta masih tingginya beban bunga pinjaman.

Konsep konsolidasi tanah vertikal sangat tepat untuk membantu dan mengatasi kebutuhan perumahan bagi masyarakat berpenghasilan menengah ke bawah dengan mengedepankan efisiensi penggunaan tanah dan penataan permukiman di kawasan perkotaan dengan mengedepankan partisipasi masyarakat. Dalam hal ini, telah ada kesepakatan bersama antara Kementrian Negara Perumahan Rakyat Republik Indonesia dengan Kepala Badan Pertanahan Nasional dengan Persatuan Perusahaan Real Estate Indonesia(REI) Nomor 22/SKB/M/2007 ; Nomor 6_SKB_BPNRI_2007 : Nomor 008/MOU/DDP REI/XI/2007 tentang Percepatan Pembangunan Rumah Susun Sederhana melalui Konsolidasi Tanah Perkotaan. Maksud dan tujuan kesepakatan bersama ini merupakan upaya bersama untuk memanfaatkan segala sumber daya yang dimiliki oleh para pihak di bidang percepatan pembangunan rumah susun sederhana melalui konsolidasi tanah perkotaan untuk meningkatkan kesejahteraan rakyat Indonesia.

Sehubungan dengan hal tersebut di atas, penelitian mengenai pengembangan kebijakan konsolidasi tanah vertikal ini sangat relevan dan perlu dilakukan, khususnya dalam rangka menghadapi kelangkaan tanah untuk pembangunan perumahan yang terjadi di kota-kota besar saat ini .

\section{B. Permasalahan Penelitian}

Konsep konsolidasi tanah perkotaan dengan pendekatan pembangunan vertikal untuk mengatasi kesulitan tanah dan perumahan di kota-kota besar merupakan salah satu alternatif yang baik untuk direalisasikan dan dikembangkan penerapannya. Namun sebelum konsep konsolidasi tanah vertikal ini menjadi suatu kebijakan pertanahan perkotaan (urban land policy) dan instrumen pembangunan perkotaan (urban development) oleh Pemerintah kota pada masa mendatang, maka seyogyanya diperlukan suatu penelitian mengenai konsep tersebut agar secara ilmiah dapat dipertanggungjawabkan. 
Sehubungan dengan permasalahan di atas tersebut, maka masalah yang ingin dikaji dalam penelitian ini difokuskan pada hal-hal sebagai berikut:

1. Sejauhmana konsep konsolidasi tanah dengan pendekatan pembangunan perumahan vertikal layak dilaksanakan/dikembangkan secara fisik, ekonomi dan sosial untuk menata kembali penguasaan, pemilikan, penggunaan dan pemanfaatan tanah di wilayah perkotaan?

2. Apakah peraturan perundang-undangan yang ada dapat mendukung pelaksanaan konsolidasi tanah secara vertikal?

\section{Maksud dan Tujuan Penelitian}

\section{Maksud}

Penelitian ini bermaksud untuk merumuskan bahan masukan alternatif dan strategis bagi kebijakan pemerintah (BPN-RI) dalam upaya menata kembali penguasaan, pemilikan dan penggunaan tanah serta mengatasi kesulitan pengadaan perumahan masyarakat di daerah perkotaan karena adanya kelangkaan tanah sebagai ruang tempat hunian dengan pendekatan konsep pembangunan konsolidasi tanah vertikal.

\section{Tujuan}

a. Mengidentifikasi, mengkaji dan menganalisis konsep/pelaksanaan konsolidasi tanah dengan pembangunan secara vertikal berkaitan dengan aturan pelaksanaan, lembaga penyelenggara, hak dan kewajiban peserta, pelaksanaan, pengelolaan, pembiayaan dan sebagainya serta mengevaluasi luas ketersediaan dan kebutuhan tanah di wilayah perkotaan untuk memenuhi keperluan pembangunan perumahan warganya serta untuk mengetahui konsep konsolidasi tanah secara vertikal yang layak dikembangkan untuk penataan pemilikan, penggunaan dan pemanfaatan tanah.

b. Mengetahui peraturan perundang-undangan yang ada dan perlu dikembangkan dalam mendukung Konsolidasi Tanah secara vertikal.

\section{Ruang Lingkup.}

Ruang Lingkup Penelitian adalah penyelenggaraan Konsolidasi Tanah Perkotaan yang telah dilaksanakan dan dengan sasaran studi meliputi :

a. Landasan hukum pelaksanaan konsolidasi tanah Vertikal (kebijakan konsolidasi Tanah Perkotaan dalam Perkaban No.4 tahun 1991 dan Kebijakan pembangunan Rumah Susun);

b. Prosedur Pelaksana meliputi pemilihan lokasi, studi kelayakan dan penetapan lokasi, perencanaan penataan, administrasi pertanahannya, pembangunan fisik, serta pembiayaan konsolidasi tanah dan sebagainya;

c. Penyelesaian hak Atas Tanah;

d. Subyek dan obyek konsolidasi tanah; 
Subjek : peserta konsolidasi tanah vertikal

Objek : Status tanah

e. Hak dan kewajiban peserta konsolidasi;

f. Organisasi penyelenggara

g. Pengendalian dan pengelolaan pelaksanaan konsolidasi tanah vertikal.

\section{E. Hasil Penelitian (Output)}

Laporan hasil penelitian berisikan :

a. Kajian data kelayakan secara fisik, ekonomi dan sosial pelaksanaan konsolidasi tanah perkotaan dengan pendekatan pembangunan perumahan vertikal untuk menata kembali lingkungan pemukiman dalam rangka meningkatkan penyediaan ruang hunian masyarakat di wilayah perkotaan.

b. Rekomendasi substansi Konsolidasi tanah Vertikal yang diatur dalam UU dan PP. 


\section{BAB II TINJAUAN PUSTAKA}

\section{A. Sistim Pemilikan Rumah Susun Di Indonesia}

Perumahan merupakan hak dasar rakyat dan dijamin oleh UUD 1945, Undang-Undang No 4 Tahun 1992 tentang Perumahan dan Permukiman, dan Undang-Undang No 39 tentang Hak Asasi Manusia. Namun apa yang menjadi hak dasar rakyat ini semakin sulit untuk diwujudkan karena terbatasnya tanah. Seiring meningkatnya populasi penduduk dan kebutuhan pembangunan, maka makin meningkat pula kebutuhan tanah bagi keperluan pembangunan. Tanah dari hari ke hari menjadi komoditas yang sulit didapat karena baik harga maupun nilainya selalu meningkat. Hal ini terjadi terutama di daerah perkotaan.

Perkotaan dengan kompleksitas permasalahan yang ada di tambah laju urbanisasi yang mencapai $4,4 \%$ per tahun membuat kebutuhan perumahan di perkotaan semakin meningkat, sementara itu ketersediaan lahan menjadi semakin langka. Kelangkaan ini menyebabkan semakin mahalnya harga lahan di pusat kota, sehingga mendorong masyarakat berpenghasilan menengahbawah tinggal di kawasan pinggiran kota yang jauh dari tempat kerja. Kondisi ini menyebabkan meningkatkan biaya transportasi, waktu tempuh, dan pada akhirnya akan menurunkan mobilitas dan produktivitas masyarakat. Sedangkan sebagian masyarakat tinggal di kawasan yang tidak jauh dari pusat aktivitas ekononomi, sehingga menyebabkan ketidak-teraturan tata ruang kota dan dapat menumbuhkan kawasan kumuh baru. Untuk mendekatkan kembali masyarakat berpenghasilan menengah-bawah ke pusat aktivitas kesehariannya dan mencegah tumbuhnya kawasan kumuh di perkotaan, maka direncanakan suatu pembangunan hunian secara vertikal, berupa Rumah Susun (Rusun).

Pengembangan Rusun kini tengah digencarkan oleh pemerintah dan masuk kedalam salah satu program pemerintah pusat yang di kenal dengan nama "Program Seribu Tower". Program ini merupakan salah satu kebijakan strategis yang dianggap tepat karena melihat pertumbuhan penduduk Indonesia yang cukup pesat pertahunnya, semakin bertambah penduduk indonesia semakin banyak lahan yang dibutuhkan untuk dijadikan lokasi permukiman atau hunian. Diketahui rata - rata pertumbuhan penduduk Indonesia adalah 2,5\% per-tahun maka sampai tahun 2025 menurut ahli demografi jumlah penduduk Indonesia akan mencapai dua kalilipat dari jumlah sekarang. Karena itu diperlukan suatu perencanaan jangka panjang kedepan untuk mengantasipasi kebutuhan penduduk akan permukiman atau hunian. Melihat pembangunan rusun yang sedang dijalankan oleh pemerintah lebih didasarkan pada mengantisipasi lonjakan kebutuhan penduduk akan hunian khususnya di wilayah perkotaan. Sehingga konsep yang dipakai adalah mengembangkan hunian vertikal untuk menghemat lahan yang dibutuhkan.

\section{Sistem Strata Title}

Beberapa negara tetangga kita melakukan pembangunan perumahan dengan sistem strata title seperti Singapura, Malaysia, Australia, Selandia Baru. Sistem strata title adalah suatu sistem yang memungkinkan pembagian tanah dan bangunan dalam unit-unit yang disebut satuan (parcel) yang masing-masing merupakan hak yang terpisah, namun disamping pemilikan secara 
individual itu dikenal pula adanya tanah, benda serta bagian yang merupakan benda milik bersama (common property). Di Malaysia, strata title mulai diperkenalkan dalam National Land Code tahun 1965, dengan prinsip yang sangat mirip dengan New South Wales Strata Title Act tahun 1961. Sistem ini di Singapura diatur dalam Land Titles (Strata Act) tahun 1970 (direvisi pada tahun 1985). ${ }^{2}$

Sistem Strata Title di New South Wales dimulai dengan memperkenalkan konsep strata title yang diatur dalam the Conveyancing (strata title) Act of 1961. Salah satu alasan sistem strata title menjadi populer ialah bahwa sebuah strata title bisa dipindah tangankan dengan bebas dan bisa diterima sebagai jaminan oleh bank, sesuatu yang mustahil dilakukan oleh sistem sebelumnya. Alasan lain ialah bahwa sistem tersebut memungkinkan dikembangkannya berbagai jenis gedung bertingkat termasuk gedung apartemen (rumah susun) untuk hunian, gedung bertingkat untuk tujuan komersial, gedung bertingkat untuk tujuan campuran antara komersial dan hunian, satuan-satuan strata untuk tujuan industri dan dermaga. Amandemen UU Strata Title di New South Wales memungkinkan diciptakannya lebih dari satu denah strata untuk gedung yang sama. ${ }^{3}$

Konsep strata title ini lahir dari adanya kebutuhan untuk hidup secara bersama-sama dalam satu kompleks gedung bertingkat tanpa di batasi oleh jangka waktu, tetapi tanah dimana gedung bertingkat itu didirikan mempunyai jangka waktu tertentu ( misal Hak Guna Bangunan untuk peraturan di Indonesia ). Dan bilamana gedung bertingkat itu runtuh secara keseluruhan maka pemilik strata title itu mempunyai hak bersama atas tanah dimana gedung itu berdiri. Bilamana strata title atas gedung itu dilakukan oleh developer maka setelah diserah terimakan unit-unit dari gedung itu kepada pemilik strata title bila terjadi hancurnya gedung itu , pihak developer tidak bertanggungjawab atau menanggung resiko untuk hal tersebut, melainkan pemegang hak strata title menanggung sendiri resiko kehancuran itu.

Prinsip-prinsip umum dalam sistem strata title dapat ditemukan dalam UURS, misalnya dalam ketentuan umum (pengertian rumah susun, satuan rumah susun, lingkungan, bagian bersama, tanah bersama, benda bersama, pemilik, penghuni, perhimpunan penghuni, badan pengelola).

\section{Sistem Kondominium}

Condominium menurut arti kata berasal dari bahasa Latin yang terdiri dari 2 kata, yaitu "con" berarti bersama-sama dan "dominium" berarti pemilikan. Dalam perkembangan selanjutnya, condominium mempunyai arti sebagai suatu pemilikan bangunan yang terdiri atas bagian-bagian yang masing-masing merupakan suatu kesatuan yang dapat digunakan dan dihuni secara terpisah, serta dimiliki secara individual berikut bagian-bagian laindari bangunan itu dan tanah di atas mana bangunan itu berdiri yang karena fungsinya digunakan bersama, dimiliki secara bersama-sama oleh pemilik bagian yang dimiliki secara individual tersebut di atas. ${ }^{4}$

Sistem pemilikan Rusun di Indonesia mempergunakan sistem Condominium sebagaimana ditemukan dalam penjelasan umum PP Nomor 4 tahun 1988 tentang Rumah Susun,

\footnotetext{
Maria SW Sumardjono. Kebijakan Pertanahan : Antara Regulasi dan Implementasi, Kompas, 2006

Arie S. Hutagalung, Kondominium dan Permasalahannya, Badan Penerbit FH UI, Jakarta, 2007.

Ibid, hal
} 
yang menyebutkan :'Sistem pemilikan perseorangan dan hak bersama (condominium). Dengan sistem condominium ini terdapat pemilikan individual dan juga pemilikan bersama (pasal 1 ayat 4, 5 dan 6 UU No. 16 tahun 1985). Dalam sistem condominium ini terdapat pemilikan individual atas satuan rumah susun yang merupakan hak penghuni. Disamping itu terdapat hak pemilikan bersama atas tanah dimana bangunan tersebut terletak (common areas), hak milik bersama atas sarana-sarana bangunan (common elements) misalnya corridor, lift, instalasi listrik, kebun, tempat rekreasi, kolam renang, lobi, garasi, dan lain sebagainya yang dapat digunakan bersama oleh para penghuni.

Dalam UURS dirumuskan suatu jenis pemilikan perseorangan dan pemilikan bersama yang disebut Hak Milik Atas Satuan Rumah Susun (HMSRS), dengan pengertian bahwa hak pemilikan perseorangan atas satuan (unit) rumah susun, meliputi pula hak bersama atas bangunan, benda dan tanahnya. HMSRS dinyatakan lahir sejak didaftarkannya Akta Pemisahan dengan dibuatnya buku tanah atas setiap satuan rumah susun yang bersangkutan (pasal 39 ayat 5 PP No. 4 tahun 1988). Pemilik satuan rumah susun yang bersangkutan harus memenuhi syarat sebagai pemegang hak atas tanah. Untuk menjamin kepastian hak bagi pemilikan satuan rumah susun, Pemerintah memberikan alat pembuktian yang kuat berupa Sertipikat Hak Milik Atas Satuan Rumah Susun, yang diterbitkan oleh Kantor Pertanahan kabupaten/Kota setempat.

Berbeda dengan Sertipikat hak atas tanah yang terdiri dari Salinan Buku Tanah dan Surat Ukur, maka Sertipikat Hak Milik Atas Satuan Rumah Susun terdiri dari :

- Salinan Buku Tanah dan Surat Ukur tanah Bersama

- Gambar Denah Tingkat Rumah Susun yang bersangkutan, yang menunjukkan satuan rumah susun yang dimiliki;

- Pertelaan mengenai besarnya bagian hak atas bagian bersama, benda bersama dan tanah bersama.

\section{Asas Pertelaan}

Dalam hukum tanah negara-negara yang menggunakan apa yang disebut "Azas Accesie" atau "asas perlekatan", bangunan dan tanaman yang ada di atas dan merupakan satu kesatuan dengan tanah, merupakan bagian dari tanah yang bersangkutan. Maka hak atas tanah dengan sendirinya, karena hukum meliputi juga pemilikan bangunan dan tanaman yang ada di atas tanah yang dihaki, kecuali kalau ada kesepakatan lain dengan pihak yang membangun atau menanamnya (KUHPerdata Pasal 500 dan 571). Perbuatan hukum mengenai tanah meliputi juga tanaman dan bangunan yang ada di atasnya. ${ }^{5}$

\section{Asas Pemisahan Horizontal}

Umumnya bangunan dan tanaman yang ada di atas tanah adalah milik yang empunya tanah. Tetapi hukum tanah kita menggunakan asas hukum adat yang disebut asas pemisahan

\footnotetext{
${ }^{5}$ Boedi Harsono, Hukum Agraria Indonesia, Sejarah Pembentukan Undang-undang Pokok Agraria, Isi dan
} Pelaksanaannya, Djambatan, Jakarta, 2005, h. 20 
horizontal ( dalam bahasa Belanda disebut"horizontale scheiding"). Bangunan dan tanaman bukan merupakan bagian dari tanah. Maka hak atas tanah tidak dengan sendirinya meliputi pemilikan bangunan dan tanaman yang ada di atasnya. Perbuatan hukum mengenai tanah, tidak dengan sendirinya meliputi pemilikan bangunan dan tanaman yang ada di atasnya. Tetapi biarpun demikian, dalam praktik dimungkinkan suatu perbuatan hukum mengenai tanah meliputi juga bangunan dan tanaman yang ada di atasnya, asal :

a. Bangunan dan tanaman tersebut secara fisik merupakan satu kesatuan dengan tanah yang bersangkutan, artinya bangunan yang berfondasi dan tanaman merupakan tanaman keras.

b. Bangunan dan tanaman tersebut milik yang empunya tanah; dan

c. Maksud demikian secara tegas disebutkan dalam akta yang membuktikan dilakukannya perbuatan hukum yang bersangkutan.

Dalam UU Nomor 4 tahun 1996 tentang Hak Tanggungan kemungkinan dibebankan Hak Tanggungan atas tanah berikut bangunan dan/atau tanaman yang ada di atasnya diperluas hingga meliputi juga bangunan dan tanaman milik pihak lain (pasal 4 ayat 5). Kiranya secara analogi perluasan tersebut dapat diterapkan juga pada perbuatan hukum pemindahan hak atas tanah yang dilakukan berikut bangunan dan/atau tanaman yang ada di atasnya. Asal pemilik bangunan dan atau tanaman tersebut ikut hadir dihadapan PPAT dan memindahkan haknya kepada penerima hak. Dengan demikian tidak perlu pemindahan hak atas bangunan dan/atau tanaman tersebut dilakukan secara terpisah dengan akta tersendiri. ${ }^{6}$

\section{B. Mekanisme Konsolidasi Tanah Di Indonesia}

\section{Konsepsi Konsolidasi Tanah}

\section{a. Pengertian}

Konsolidasi secara terminologis berasal dari bahasa Inggris yaitu 'consolidation" yang berarti mempersatukan keadaan tempat fisik bagi fasilitas-fasilitas, kelengkapan, atau orangorang. Di Jepang dan Korea, konsolidasi tanah dikenal dengan istilah land readjustment, di Australia dikenal dengan istilah land pooling sedangkan di Taiwan digunakan istilah land consolidation. Di Indonesia istilah baku yang sering digunakan adalah Konsolidasi Tanah (selanjutnya disingkat KT).

Terdapat berbagai pengertian tentang arti dari KT ini. Namun pada prinsipnya KT adalah suatu model pembangunan yang mengatur semua bentuk tanah yang semula terpecahpecah dan tata letaknya tak teratur, melalui cara penggeseran, penataan, pertukaran, penggabungan, pemecahan, penghapusan dan pengubahan letak persil tanah yang disempumakan dengan adanya pembangunan fasilitas urnum seperti jalan, jalur hijau dan sebagainya, sehingga menghasilkan pemanfaatan tanah yang lebih baik (ekonomis) dan memenuhi berbagai persyaratan.

\footnotetext{
${ }^{6} \mathrm{Ibid}$, hal 263
} 
Prinsip dasar dan konsolidasi tanah ini adalah bahwa segala biaya yang diperlukan untuk kegiatan konsolidasi ini ditanggung bersama oleh pemilik tanah dengan kata lain dengan swadaya masyarakat. Konsolidasi tanah juga dapat dipandang sebagai suatu rangkaian mekanisme pembangunan tanah mencakup proses, produk, dan instrumen pendukung yang khas. Karenanya penataan tanah dengan KT baru dapat dilaksanakan setelah memperoleh persetujuan masyarakat pemilik tanah, baik dalam perencanaan maupun pelaksanaannya. Sehingga penataan dan pembangunan tanpa menggusur pemilik tanah peserta KT

Tujuan dan sasaran KT adalah untuk mencapai pemanfaatan tanah secara optimal, melalui peningkatan efisiensi dan produktifitas penggunaan tanah dan terwujudnya suatu tatanan penguasaan dan penggunaan tanah yang tertib dan teratur tanpa merugikan siapapun karena sesudah pembangunan nilainya tetap bahkan dapat meningkat beberapa kali lipat. Dan yang lebih utama lagi melalui KT ini, tidak terjadi penggusuran penduduk/pemilik tanah ketempat lain seperti halnya pada pembebasan tanah.

\section{b. Aturan Pelaksanaan}

Peraturan-peraturan yang berkaitan dengan pelaksanaan KT adalah :

\section{1) Undang-undang Dasar Negara RI 1945}

Berdasarkan ketentuan Pasal 33 ayat (3) yang menentukan "Bumi, air dan kekayaan yang terkandung di dalammnya dikuasai negara dan dipergunakan sebesarbesarnya untuk kemakmuran rakyat" dapat disimpulkan bahwa: konsep "dikuasai negara" artinya negara mengatur, negaralah yang mempunyai kewenangan mengelola dan mengatur tanah guna sebesar-besarnya kemakmuran rakyat. Dengan kata lain, pada tingkatan tertinggi negaralah yang berhak mengatur peruntukan dan pemanfaatannya. Pengaturan oleh Negara diperlukan karena kekhawatiran bahwa tanpa campur tangan negara akan terjadi ketidakadilan dalam akses terhadap perolehan dan pemanfatan sumber daya alam oleh masyarakat. Ketegasan kewenangan yang demikian adalah kewenangan yang diatribusikan dalam Undang-Undang Dasar sehingga negara berhak untuk menuntut kepatuhan. Dengan demikian, kewenangan Negara dalam bidang pertanahan termasuk penataan tanah melalui konsolidasi tanah baru dapat ditentukan apabila didasarkan pada perluasan tafsir dari pasal 33 ayat (3) UUD 1945. Atas dasar itulah pasal 33 ayat (3) UUD 1945 dicantumkan dalam konsideran "mengingat" dalam regulasi konsolidasi tanah.

Mengingat ketentuan pasal 28 H UUD 1945 bahwa: "Setiap orang berhak hidup sesejahtera lahir dan batin, bertempat tinggal, dan mendapatkan lingkungan hidup yang baik dan sehat serta berhak memperolah pelayanan kesehatan", langkah mengelola dan mengatur tanah oleh Negara termasuk juga untuk memperbaiki kualitas atau nilai tanah melalui konsolidasi tanah adalah ditujukan guna sebesar-besarnya kemakmuran rakyat. Dengan penafsiran tersebut menjadikan Negara mempunyai kewenangan untuk mengatur dan mengelola (beheersdaad) tanah di wilayah Indonesia. 


\section{2) Undang-undang Nomor 5 Tahun 1960 tentang Peraturan Dasar Pokok-pokok Agraria;}

Hak menguasai tanah dari Negara sebagaimana dimaksud Undang-undang Pokok Agraria, Pasal 2 ayat (2), memberi wewenang untuk :

a) Mengatur dan menyelenggarakan peruntukan, penggunaan, persediaan dan pemeliharaan bumi air dan ruang angkasa;

b) Menentukan dan mengatur hubungan-hubungan antara orang-orang dengan bumi, air dan ruang angkasa;

c) Menentukan dan mengatur hubungan-hubungan hukum antara orang-orang dan perbuatan-perbuatan hukum yang mengenai bumi, air dan ruang angkasa.

Kewenangan mengatur dan menyelenggarakan peruntukan, penggunaan, persediaan dan pemeliharaan bumi, air dan ruang angkasa tersebut di atas merupakan kewenangan penataan. Oleh karena ternyata penguasaan dan penggunaan tanah umumnya telah ada sebelum ditetapkan peruntukannya sesuai perkembangan masyarakat dan budayanya maka penataan tersebut pada hakekatnya adalah penataan kembali. Oleh karena penataan ini menyangkut perubahan penguasaan dan penggunaan tanah seseorang atau kelompok/masyarakat maka dalam pelaksanaannya harus memperoleh persetujuan serta melibatkan patisipasi aktif dari yang bersangkutan.

Pasal 6 pada UU ini menentukan bahwa semua hak atas tanah mempunyai fungsi sosial. Penegasan fungsi sosial dari setiap hak atas tanah dapat ditafsirkan bahwa hak atas tanah pada dasarnya tidak menjadi penghalang bagi pemerintah untuk melakukan kewenangan publiknya untuk melakukan kewenangan tanah. Salah satu contohnya adalah program Konsolidasi Tanah. Demikian pula dengan pasal 12 dan 14 bahwa hak menguasai Negara ditujukan sebesar-besar kemakmuran rakyat meliputi, kebahagiaan, kesejahteraan, dan kemerdekaan dalam masyarakat dan Negara Indonesia yang merdeka, berdaulat, adil dan makmur. Dengan demikian, kewenangan Negara yang bersifat publik menjadi dasar hokum yang bersifat umum bagi pemerintah melalui UU ini untuk melakukan pengaturan, penataan, penguasaan, dan penggunaan tanah yang ditafsirkan termasuk penataan melalui konsolidasi tanah.

\section{3) Undang-Undang No. 16 Tahun 1985 tentang Rumah Susun}

Konsolidasi Tanah permukiman adalah upaya penataan kembali penguasaan, penggunaan, dan pemilikan tanah oleh masyarakat pemilik tanah melalui usaha bersama untuk membangun lingkungan siap bangun dan menyediakan kaveling tanah matang sesuai dengan rencana tata ruang yang ditetapkan Pemerintah Daerah Tingkat II, khusus untuk DKI Jakarta rencana tata ruangnya ditetapkan oleh Pemda DKI Jakarta (Pasal 1 Ayat (11) UU No. 4 Tahun 1992 Tentang Perumahan dan Permukiman).

Untuk daerah yang penyediaan tanahnya terbatas perlu dilakukan Konsolidasi Tanah secara vertikal dengan pembangunan Rumah Susun. Rumah Susun adalah bangunan gedung bertingkat yang dibangun dalam suatu lingkungan, yang terbagi dalam bagian yang distrukturkan secara fungsional dalam arah horizontal maupun vertikal dan 
merupakan satuan-satuan yang masing-masing dapat dimiliki dan digunakan secara terpisah terutama bagian bersama, benda bersama dan tanah bersama.

\section{4) Undang-undang Nomor 4 Tahun 1992 tentang Perumahan dan Permukiman}

Pasal 25 menyatakan bahwa, pembangunan lingkungan siap bangun yng dilakukan masyarakat pemilik tanah melalui konsolidasi tanah dengan memperhatikan ketentuan pasal 7, dapat dilaksanakan secara bertahap yang meliputi kegiatan-kegiatan :

- Pematangan tanah;

- Penataan, penggunaan, penguasaan dan pemilikan tanah;

- Penyediaan prasarana lingkungan;

- Penghijauan lingkungan; dan

- Pengadaan tanah untuk sarana lingkungan.

pasal 32 ayat (1) menyatakan bahwa :

Penyediaan tanah untuk pembangunan perumahan dan permukiman diselenggarakan dengan :

a. penggunaan tanah yang langsung dikuasai oleh negara;

b. konsolidasi tanah oleh pemilik tanah;

c. pelepasan hak atas tanah oleh pemilik tanah yang dilakukan sesuai dengan peraturan perundang-undangan yang berlaku.

Ayat (2): Tata cara penggunaan tanah yang langsung dikuasai negara dan tata cara konsolidasi tanah oleh pemilik tanah sebagai mana dimaksud dalam ayat (1) butir $a$ dan $b$ diatur dengan Peraturan Pemerintah.

\section{5) Undang-Undang Nomor 28 Tahun 2002 tentang Bangunan Gedung}

Bangunan gedung merupakan salah satu wujud fisik pemanfaatan ruang. Oleh karena itu dalam pengaturan bangunan gedung tetap mengacu pada pengaturan penataan ruang sesuai peraturan perundang-undangan yang berlaku. Untuk menjamin kepastian dan ketertiban hukum dalam penyelenggaraan bangunan gedung, setiap bangunan gedung harus memenuhi persyaratan administratif dan teknis bangunan gedung, serta harus diselenggarakan secara tertib. Undang-undang tentang Bangunan Gedung mengatur fungsi bangunan gedung, persyaratan bangunan gedung, penyelenggaraan bangunan gedung, termasuk hak dan kewajiban pemilik dan pengguna bangunan gedung pada setiap tahap penyeleng-garaan bangunan gedung, ketentuan tentang peran masyarakat dan pembinaan oleh pemerintah, sanksi, ketentuan peralihan, dan ketentuan penutup. Pada pasal 5 menyatakan bahwa Bangunan gedung fungsi hunian meliputi bangunan untuk rumah tinggal tunggal, rumah tinggal deret, rumah susun, dan rumah tinggal sementara. 


\section{6) Undang-undang Nomor 26 Tahun 2007 tentang Penataan Ruang}

Dalam penjelasan pasal 34 menyatakan bahwa Pengembangan kawasan secara terpadu dilaksanakan, antara lain, melalui penerapan kawasan siap bangun, lingkungan siap bangun yang berdiri sendiri, konsolidasi tanah, serta rehabilitasi dan revitalisasi kawasan.

\section{7) Peraturan Pemerintah No. 16 tahun 2004 tentang Penatagunaan Tanah}

Pasal 23

(4). Pelaksanaan pola penyesuaian penguasaan, penggunaan dan pemanfaatan tanah dengan Rencana Tata Ruang Wilayah sebagaimana dimaksud dalam Pasal 22 ayat

(1) huruf c dilakukan melalui:

(a) penataan kembali;

(b) upaya kemitraan;

(c) penyerahan dan pelepasan hak atas tanah kepada negara atau pihak lain dengan penggantian sesuai dengan peraturan perundang-undangan,

(5). Penyesuaian sebagaimana dimaksud pada ayat (4) dilaksanakan dengan mempertimbangkan:
(a) kebijakan penatagunaan tanah;
(b) hak-hak masyarakat pemilik tanah;
(c) investasi pembangunan prasarana dan sarana;
(d) evaluasi tanah.

(6). Dalam pelaksanaan penyesuaian sebagaimana dimaksud pada ayat (4) dilakukan dengan melibatkan peranserta masyarakat sesuai dengan peraturan perundangundangan.

(7). Tata cara pelaksanaan kegiatan sebagaimana dimaksud pada ayat (1), ayat (3) dan ayat (4) diatur dalam berbagai pedoman, standar dan kriteria teknis yang ditetapkan oleh Pemerintah.

(8). Pedoman, standar dan kriteria teknis pelaksanaan kegiatan penatagunaan tanah sebagaimana dimaksud pada ayat (7) dijabarkan lebih lanjut oleh Pemerintah Kabupaten/Kota.

Pasal 24

(1). Dalam rangka pelaksanaan pola penyesuaian penguasaan, penggunaan dan pemanfaatan tanah, Pemerintah Kabupaten/Kota menerbitkan pedoman teknis.

(2). Tata cara penerbitan pedoman teknis sebagaimana dimaksud pada ayat (1) dilaksanakan sesuai dengan peraturan perundang-undangan yang berlaku. 


\section{8) Undang-undang Nomor 32 tahun 2004 tentang Pemerintahan Daerah}

1). Pasal 13 Urusan wajib yang menjadi kewenangan pemerintah daerah untuk kabupaten/kota merupakan urusan yang berskala kabupaten/kota meliputi : (a). Perencanaan dan pengendalian pembangunan, (b). Perencanaan, pemanfaatan dan pengawasan tata ruang, (d). Penyediaan sarana dan prasarana umum,(k) pelayanan pertanahan termasuk lintas kabupaten/kota;

2). Pasal 14 Urusan wajib yang menjadi kewenangan pemerintah daerah untuk kabupaten/kota merupakan urusan yang berskala kabupaten/kota meliputi : (a). Perencanaan dan pengendalian pembangunan, (b). Perencanaan, pemanfaatan dan pengawasan tata ruang, (d). Penyediaan sarana dan prasarana umum,(k) pelayanan pertanahan;

3). Pelaksanaan ketentuan sebagaimana dimaksud dalam Pasal 13 dan Pasal 14 ayat (1) dan ayat (2) diatur lebih lanjut dengan Peraturan Pemerintah.

4). Pasal 22 Dalam menyelenggarakan otonomi, daerah mempunyai kewajiban : (i). Menyusun perencanaan dan tata ruang;

\section{9) Peraturan Presiden Nomor 10 Tahun 2006 tentang Badan Pertanahan Nasional}

Pasal 2 menyatakan bahwa, Badan Pertanahan Nasional mempunyai tugas melaksanakan tugas pemerintahan di bidang pertanahan secara nasional, regional dan sektoral. Tugas dan fungsi BPN tidak hanya berfungsi administratif, tetapi juga mempunyai fungsi untuk merumuskan kebijaksanaan yang berkaitan dengan pertanahan, baik berdasarkan UUPA ataupun peraturan perundang-undangan lainnya. Karena bidang pertanahan adalah hal yang komplek dan menyangkut kepentingan banyak instansi, maka memerlukan kerjasama dengan lembaga-lembaga lainnya. Aspek koordinasi antar sektor (instansi lain) sangat penting sesuai permasalahan dan programnya. Konsolidasi tanah karena pelaksanaannya di tingkat Kabupaten/Kota, dikoordinasikan oleh Bupati/Walikota.

\section{0) Keputusan Presiden Nomor 22 tahun 2006 tentang Tim Koordinasi Percepatan} Pembangunan Rumah Susun di Kawasan Perkotaan

Percepatan pembangunan rumah perlu dilakukan secara terarah dan terkoordinasi diantara instansi pemerintah, dengan melibatkan peran serta dan partisipasi dari badan usaha dan masyarakat. Sehubungan dengan petimbangan tersebut dipandang perlu membentuk Tim Koordinasi Percepatan Pembangunan Rumah Susun di Kawasan Perkotaan.

Susunan keanggotaan Tim Koordinasi adalah sebagai berikut :

a. Ketua merangkap anggota : Menteri Koordinator Bidang Perekonomian;

b. Ketua Harian merangkap anggota : Menteri Negara Perumahan Rakyat;

c. Anggota : 1. Menteri Dalam Negeri; 
2. Menteri Keuangan;

3. Menteri Pekerjaan Umum;

4. Menteri Sosial;

5. Menteri Pertahanan;

6. Menteri Negara Perencanaan Pembangunan Nasional / Kepala Badan Perencanaan Pembangunan Nasional

7. Kepala Badan Pertahanan Nasional;

8. Direktur Utama Bank Tabungan Negara;

d. Sekretaris I : Sekretaris Menteri Negara Perumahan Rakyat;

e. Sekrtetaris II : Deputi Menteri Koordinator Bidang Perekonomian Bidang Infrastruktur dan Pengembangan Wilayah;

\section{1) Peraturan KaBPN Nomor 4 Tahun 1991 tentang Konsolidasi Tanah.}

Konsoliasi tanah adalah kebijaksanaan pertanahan mengenai penataan kembali penguasaan dan penggunaan tanah serta usaha pengadaan tanah untuk kepentingan pembangunan, untuk meningkatkan kualitas lingkungan dan pemeliharaan sumberdaya alam dengan melibatkan partisipasi aktif masyarakat. Sasaran konsolidasi tanah adalah terwujudnya suatu tatanan penguasaan dan penggunaan tanah yang tertib dan teratur. Dalam rangka peningkatan kualitas lingkungan dan sekaligus menyediakan tanah untuk pembangunan prasarana dan fasilitas umum dilaksanakan pengaturan dan penatagunaan tanah dalam bentuk konsolidasi tanah di wilayah perkotaan dan pedesaan. Kegiatan Konsolidasi tanah meliputi penataan kembali bidang-bidang tanah termasuk hak atas tanah dan atau penggunaan tanahnya dengan dilengkapi prasarana jalan, irigasi, fasilitas lingkungan dan atau serta fasilitas penunjang lainnya yang diperlukan, dengan melibatkan partisipasi para pemilik tanah dan atau penggarap tanah.

\section{2) Peraturan KaBPN Nomor 3 Tahun 2006 tentang Organisasi Dan Tata Kerja Badan Pertanahan Nasional Republik Indonesia}

Pasal 260 menyatakan bahwa Direktorat Konsolidasi Tanah mempunyai tugas menyiapkan perumusan kebijakan teknis dan melaksanakan konsolidasi tanah. Dalam melaksanakan tugas sebagaimana dimaksud dalam Pasal 260, Direktorat Konsolidasi Tanah menyelenggarakan fungsi:

a. penyiapan rumusan kebijakan teknis di bidang konsolidasi tanah perkotaan dan perdesaan;

b. penyusunan norma, standar, pedoman dan mekanisme konsolidasi tanah;

c. penyiapan program nasional dan pelaksanaan konsolidasi tanah;

d. pengembangan teknik dan metode pelaksanaan konsolidasi tanah;

e. penyiapan desain konsolidasi; 
f. penyediaan tanah untuk keperluan pembangunan tanpa penggusuran;

g. penataan tanah untuk pengembangan wilayah, kawasan dan lingkungan siap bangun, peremajaan kota, daerah bencana dan daerah bekas konflik, serta pemukiman kembali;

h. penataan tanah pertanian skala kecil untuk optimalisasi pengusahaannya;

i. promosi dan sosialisasi konsolidasi tanah;

j. fasilitasi pembangunan infrastruktur melalui koordinasi dan kerja sama dengan instansi/lembaga terkait dan Pemerintah Daerah;

k. pengorganisasian dan pembimbingan masyarakat dalam konsolidasi tanah;

1. penguasaan dan pengelolaan sumbangan tanah untuk pembangunan (STUP);

m. monitoring dan evaluasi pelaksanaan konsolidasi tanah; dan

n. pengelolaan basis data dan informasi konsolidasi tanah.

\section{Organisasi Pelaksana}

Pada umumnya inisiatif penyelenggaraan KT di berbagai negara (Badan Penyelenggara Proyek Konsolidasi Tanah) berasal dari :

a. Pemerintah, dalam hal ini bisa satu Departemen atau Lembaga Pemerintah yang mengelola bidang pertanahan, bisa Kepala Pemerintahan Daerah Tingkat I (Gubernur KDH Tk.I) dan bisa pula Kepala Pemerintahan Daerah Tingkat II (Bupati/Walikota) baik atas pertimbangan politis maupun atas pertimbangan administratif.

Biasanya dilaksanakan dalam rangka merehabilitir daerah-daerah perkotaan yang sering terkena bencana banjir dan/atau bencana lainnya, memperbaiki lingkungan pemukiman yang kumuh sekaligus dalam rangka mengurangi kepadatan arus lalu lintas, namun tetap sesuai/konsisten dengan rencana tata kota (City Planning) yang ada.

Konsep rencana proyek dibuat oleh aparat Pemerintahan yang bersangkutan, kemudian dirundingkan dengan pemuka-pemuka, organisasi kemasyarakatan dan para pemilik tanahnya; dan penyelenggaraannya baru dapat dijalankan setelah mendapat persetujuan dari Pejabat yang lebih tinggi.

b. Masyarakat pemilik tanah sendiri, baik secara perseorangan maupun yang berhimpun dalam suatu perkumpulan (Assosiasi), yang atas kesadaran sendiri berkeinginan agar lingkungan hidupnya dapat menjadi lebih baik, persil-persil tanah mereka dapat menjadi teratur bentuknya, lebih efektif pemanfaatannya serta nilai ekonomis tanahnya dapat lebih ditingkatkan.

Dengan bantuan tenaga teknis dari Pemerintah, disusun konsep rencana proyeknya, kemudian disodorkan kepada para pemilik tanah baik melalui ajakan langsung secara berantai maupun melalui rapat-rapat lokal. 
c. Lain dari itu, tidak tertutup pula kemungkinan bagi suatu Perusahaan Umum untuk menjadi inisiator, bahkan mereka termasuk Pemerintah sendiri dapat menjadi peserta konsolidasi.

d. Peraturan KaBPN Nomor 4 Tahun 1991, organisasi pelaksana konsolidasi tanah adalah Pemerintah dalam hal ini secara fungsional dilaksanakan oleh Badan Pertanahan Nasional.

\section{Hak dan Kewajiban Peserta}

\section{a. Hak Peserta KT}

1). Memahami konsep, mengetahui rencana dan pelaksanaan KT;

2). Memperoleh informasi yang jelas dan terbuka mengenai rencana, proses dan pelaksanaan KT;

3). Memperoleh informasi yang jelas dan terbuka mengenai besarnya biaya pelaksanaan dan pembangunan;

4). Memberikan pendapat dan peranserta dalam proses pelaksanaan KT;

5). Memperoleh hak atas tanah/bangunan yang telah disepakati setelah penataan;

6). Tidak dibebani pungutan/biaya lainnya di luar kesepakatan.

b. Kewajiban Peserta KT

1). Menyerahkan secara proporsional dan adil tanahnya untuk pembangunan dan pelaksanaan KT;

2). Mentaati aturan pelaksanaan KT sesuai rencana yang telah disepakati.

\section{Prosedur Pelaksanaan}

Prosedur penyelenggaraan KT ini secara dapat diuraikan sebagai berikut :

a. Penentuan Organisasi penyelenggara.

\section{Badan Penyelenggara KT.}

Pada umumnya inisiatif penyelenggaraan di berbagai negara berasal dari :

1) Pemerintah, dalam hal ini bisa satu Departemen atau Lembaga Pemerintah yang mengelola bidang pertanahan, bisa Kepala Pemerintahan Daerah Tingkat I (Gubernur KDH Tk.I) dan bisa pula Kepala Pemerintahan Daerah Tingkat II (Bupati/Walikota) baik atas pertimbangan politis maupun atas pertimbangan administratif.

2) Konsep rencana proyek dibuat oleh aparat Pemerintahan yang bersangkutan, kemudian dirundingkan dengan pemuka-pemuka, organisasi kemasyarakatan dan para pemilik tanahnya; dan penyelenggaraannya baru dapat dijalankan setelah mendapat persetujuan dari Pejabat yang lebih tinggi. 
Masyarakat pemilik tanah sendiri, baik secara perseorangan maupun yang berhimpun dalam suatu perkumpulan (Assosiasi), yang atas kesadaran sendiri berkeinginan agar lingkungan hidupnya dapat menjadi lebih baik, persil-persil tanah mereka dapat menjadi teratur bentuknya, lebih efektif pemanfaatannya serta nilai ekonomis tanahnya dapat lebih ditingkatkan. Dengan bantuan tenaga teknis dari Pemerintah, disusun konsep rencana proyeknya, kemudian ditawarkan kepada para pemilik tanah baik melalui ajakan langsung secara berantai maupun melalui rapat-rapat lokal. Lain dari itu, tidak tertutup pula kemungkinan bagi suatu Perusahaan Umum untuk menjadi inisiator, bahkan mereka termasuk Pemerintah sendiri dapat menjadi peserta konsolidasi.

b. Pemilihan dan penetapan lokasi.

Pemilihan lokasi yang tepat merupakan tolok ukur keberhasilan suatu Proyek KT. Untuk itu perlu diketahui dan dipedomani dalam menentukan calon-calon lokasi tersebut antara lain dengan kriteria pokok pemilihan lokasi sebagai berikut:

1) Calon lokasi harus konsisten dengan Rencana Induk/Rencana Tata Ruang Kota atau kalau belum ada harus memenuhi unsur-unsur kebijaksanaan pembangunan kota. Pengertian konsisten di sini adalah; daerah yang akan dikonsolidasikan harus ada dalam Rencana Induk/Rencana Tata Ruang Kota/Rencana Bagian Wilayah Kota yang penggunaannya sudah ditentukan, atau kalau belum ada harus memenuhi unsur-unsur kebijaksanaan pembangunan kota, sehingga dengan demikian usaha KT ini merupakan usaha tindak lanjut dari Rencana Induk/Rencana Tata Ruang Kota itu sendiri.

2) Calon lokasi telah mempunyai jalan akses (jangkauan) ke daerah yang sudah terbuka. Hal ini dimaksudkan guna mempercepat perkembangan daerah yang dikonsolidasi dan menghemat biaya konstruksi (tambahan biaya berupa ongkos angkut material bangunan atau harus membangun jalan akses sendiri), dan biaya untuk prasarana tersebut tidak diperlukan lagi karena prasarananya sudah ada.

3) Kwalitas lingkungan calon lokasi rendah serta bentuk dan batas pemilikan tanah tidak teratur.

4) Jumlah pemilik tanah peserta konsolidasi yang mempunyai luas tanah dibawah standar minimum perumahan harus lebih sedikit, guna menghindari pemindahan penduduk atau penggabungan pemilikan tanah. Syarat ini penting untuk menghindari penciptaan-penciptaan spekulan, sebab hal ini akan lebih menguntungkan bagi pemilik tanah dalam jumlah besar/luas dari pada kepentingan umum dan pemerintah. Sehingga hal ini tidak sesuai dengan tujuan pokok konsolidasi tanah itu sendiri.

5) Bangunan yang ada dalam areal calon lokasi relatif sedikit dan sifat bangunannya semi permanen dan/atau sementara. Hal ini akan mempermudah proses pelaksanaan selanjutnya serta menghindari biaya yang lebih tinggi yang diakibatkan oleh biaya ganti rugi dan pemindahan bangunan.

6) Calon lokasi harus layak dikonsolidasi. Syarat-syarat kelayakan adalah sebagai berikut : 
Bagi kepentingan pemilik tanah :

Nilai total pemilikan tanah/bangunan yang akan didistribusikan kembali kepada pemilik semula harus lebih besar atau sama dengan nilai total pemilikan tanah/bangunan sebelum konsolidasi.

Bagi kepentingan Pemerintah :

Nilai seluruh pemilikan tanah/bangunan setelah proyek ditambah dengan biaya pembangunan, harus lebih besar atau sama dengan harga seluruh tanah/bangunan sebelum proyek ditambah seluruh biaya pelaksanaan proyek.

Bagi kepentingan developer :

Biaya untuk pembangunan harus lebih kecil atau sama dengan harga jual tanah/bangunan hasil konsolidasi.

7) Penetapan batas lokasi harus sejelas mungkin (dapat berupa batas fisik alam/batas buatan), agar lokasi tersebut merupakan suatu kesatuan areal perencanaan.

8) Sesuai dengan kebijaksanaan dan pengembangan kota atau Rencana Umum Tata Ruang maka pemilihan lokasi diarahkan dan disesuaikan dengan RUTR dan atau kebijaksanaan dan pengembangan kota terebut.

c. Pendekatan dengan Pemerintah Daerah, Instansi Terkait Tokoh Masyarakat dan para pemilik tanah.

KT merupakan kegiatan pembangunan terpadu yang melibatkan berbagai instansi, yang menyangkut banyak aspek dan pemilik tanah. Sesuai dengan situasi dan kondisi di Indonesia, dimana dalam penataan/pembangunan suatu wilayah harus melibatkan beberapa instansi terkait, maka pada tahap persiapan dilakukan pendekatan dan penyluhan dengan instansi-instansi terkait, tokoh masyarakat dan para pemilik tanah peserta konsolidasi untuk memperoleh dukungan dan persamaan persepsi agar diperoleh keterpaduan gerak dan langkah dalam pembangunan tersebut.

d. Pengukuran dan pemetaan.

Dalam rangka KT diperlukan kegiatan pengukuran dan pemetaan pada lokasi yang telah ditetapkan sebagai KT, dan dilakukan inventarisasi yang menyangkut aspek fisik, aspek sosial dan ekonomi dan dilakukan pengukuran untuk mengetahui pemilik, luas dan status pemilikan, topografinya dan penggunaan tanahnya.

e. Pembuatan Rencana Pembangunan Vertikal.

Secara teoritis, rencana pembangunan vertikal pada dasarnya merupakan tindakan yang akan dilakukan pada masa yang akan datang.

f. Penyuluhan.

Penyuluhan kepada para pemilik tanah peserta konsolidasi untuk memperoleh persetujuan pelaksanaan konsolidasi. 
Penyuluhan kepada para pemilik tanah peserta konsolidasi diperlukan dalam rangka untuk memperoleh pengertian dan persamaan persepsi tentang konsep konsolidasi tanah vertikal serta persetujuan atas pelaksanaan konsolidasi tanah vertikal tersebut.

Penyuluhan untuk memperoleh persetujuan terhadap rencana konsep.

Untuk kelancaran pelaksanaan konsolidasi tanah vertikal, kepada para pemilik tanah untuk memperoleh persetujuan terhadap rencana konsep pembangunan perumahan secara vertikal, kebutuhan sarana dan prasarana lingkungan sesuai dengan kebutuhan;

Penyuluhan untuk memperoleh persetujuan terhadap rencana penempatan dan besarnya bangunan yang akan diterima setelah proyek;

Penyuluhan kepada para pemilik tanah peserta konsolidasi dalam rangka untuk memperoleh persetujuan terhadap rencana penempatan dan besarnya bangunan yang akan diterima setelah proyek berikut penyelesaian administrasi pertanahannya.

g. Penyusunan tata letak persil/kapling baru.

Prinsip dasar tata letak persil/kaplimg baru adalah proses penentuan perolehan persil/kapling yang ditata kembali, di mana lokasinya, bagaimana bentuk dan luasnya.

h. Pembangunan fisik perumahan secara vertikal.

KT merupakan kegiatan pembangunan terpadu yang melibatkan berbagai instansi, yang menyangkut banyak aspek, dimana dalam penataan/pembangunan harus melibatkan beberapa instansi terkait, maka pada tahap persiapan dilakukan pendekatan dan penyuluhan dengan instansi-instansi terkait, tokoh masyarakat dan para pemilik tanah peserta konsolidasi untuk memperoleh dukungan dan persamaan persepsi agar diperoleh keterpaduan gerak dan langkah dalam pembangunan tersebut. Demikian juga dalam merencanakan biaya pembangunan fisik harus sudah direncanakan dari sejak awal pelaksanaan. Dengan adanya perencanaan yang lebih matang dan adanya persamaan persepsi dan keterpaduan gerak dan langkah dalam pembangunan diharapkan akan tercapai hasil yang lebih baik.

i. Penyelesaian administrasi pertanahan sampai dengan sertifikasi persil/kapling baru.

Prosedur dan dasar hukum penyelesaian administrasi Hak Atas Tanah dengan sertifikasi pesil/kapling baru dalam pelaksanaan KT (secara horizontal), dari hasil penelitian Puslitbang BPN, pada umumnya ditempuh dengan prosedur Redistribusi Landreform, yaitu dengan jalan:

Pelepasan hak atas tanah kepada Negara;

Penegasan tanah menjadi obyek Landreform/obyek Konsolidasi Tanah;

Penerbitan SK. Hak milik/redistribusi Landreform berdasarkan pada PP. No. 224 tahun 1961, oleh Kepala Kantor Wilayah BPN Propinsi.

Namun demikian ada juga yang menggunakan prosedur pemberian Hak dengan Peraturan Menteri Dalam Negeri No. 5 tahun 1973, yaitu seperti Proyek Penataan 
Pemukiman di daerah Minapadi, Kodya Surakarta. Setelah ada SK Pemberian Hak kepada para peserta Proyek Konsolidasi Tanah, kemudian ditindaklanjuti dengan pemberian sertifikat atas tanahnya. Namun demikian pemberian sertifikat tidak langsung (ada tenggang waktu) dan dilanjutkan dengan proyek lain seperti PRONA.

Dalam menyelesaikan administrasi pertanahannya perlu diperhatikan struktur penguasaan tanah sebagaimana yang diatur dan ditetapkan dalam UUPA, dan dengan proses yang mengacu pada peraturan-peraturan yang sudah ada.

j. Pengelolaan dan pengendalian

Pengelolaan dan pengendalian pelaksanaan konsolidasi tanah mulai tahap Rencana Pelaksanaan sampai dengan Konstruksi dilakukan oleh Penanggung Jawab KT;

Pengelolaan dan pengendalian berpedoman kepada Rencana Umum Pelaksanaan KT, Rencana Blok, Rencana Penataan Persil/Bangunan Baru yang telah disepakati oleh peserta KT dan disetujui oleh Penanggung Jawab;

Penanggung Jawab KT bertanggung jawab kepada peserta KT dan melaporkan hasil kegiatannya;

Pengelolaan dan pengendalian KT diatur lebih lanjut dengan Peraturan Perundangundangan.

\section{Potensi Implikasi Penerapan Metoda Konsolidasi Tanah Bagi Pengembang Perumahan Real Estat}

Secara umum dapat dikatakan bahwa implikasi KT pada perilaku investasi pengembang di Indonesia meliputi antara lain: pertama, tidak memungkinkan akuisisi tanah secara murni sehingga akan menyulitkan perolehan keuntungan dengan melakukan spekulasi pada lahan; kedua, tidak ada monopoli hak tanah oleh pengembang sehingga pengembang harus bekerjasama dengan pemilik lahan lainnya; ketiga, pertambahan nilai lahan akan kembali pada semua pemilik lahan yang terlibat bukan hanya pada pengembang; keempat, tidak ada fleksibilitas dalam merancang site; dan kelima, profit tidak bisa dari penguasaan lahan semata, yang mungkin diambil profitnya adalah dari proses membangun infrastruktur, mematangkan lahan, dan membangun rumah.

Dari proses perilaku investasi tersebut akan terdapat implikasi bentukan fisik pada perumahan real estat, antara lain: tidak mungkin menerapkan konsep newtownianism, layout site/kapling akan berbeda yaitu hampir tidak bisa membentuk kapling eksklusif, serta tuntutan terbentuknya kontinuitas jaringan infrastruktur dengan areal sekitarnya. Implikasi yang terjadi bila pengembang memakai metoda KT pada produk perumahan real estat menurut argumentasi anggotaREI antara lain (Harun, 1998):

a. Mengurangi salah satu daya tarik pemasaran perumahan real estat yaitu tema modernitas dan eksklusifitas.

b. Mengurangi atau membatasi pemakaian lahan secara intensif untuk fungsi komersial, karena sebagian lahan harus didistribusikan kembali pada pemilik lahan semula setelah proses onsolidasi. 
c. Tanah Pengganti Biaya Pembangunan (TPBP) atau Cost-Equivalent Land (CEL) terlalu kecil bagi peserta di luar pemilik lahan yang dikonsolidasikan (outside parties) seperti pihak developer.

d. Kendala sulitnya pensegmentasian pasar khusus produk lingkungan hasil KT untuk konsumen dengan pendapatan tertentu, khususnya masyarakat berpenghasilan tinggi.

Terdapat kendala pengembang selama proses KT yang diterapkan di berbagai negara, antara lain:

a. Potensi defisit pada proyek Bagi proyek dengan dasar perhitungan pendanaan privat di mana terjadi interaksi dengan beragam pemilik lahan, maka surplus bagi sebuah pihak (misal pemilik tanah) tidak dapat menutupi deficit yang dialami pihak lain, dalam hal ini pengembang tersebut.

b. Kesulitan-kesulitan pada saat proses KT. Kesulitan ini meliputi sosialisasi proyek pada pihak-pihak pemilik lahan yang terlibat dalam KT, mendirikan asosiasi bersama pemilik lahan lain, mengatur pendanaan, serta membuat perencanaan.

c. Delay waktu

Bisa dikatakan bahwa metoda KT adalah metoda yang membutuhkan waktu yang cukup lama terutama pada tahap negosiasi- negosiasi di setiap langkah atau prosedurnya. Bila terjadi kesulitan atau kegagalan negosiasi pada satu langkah maka akan membuat pengunduran waktu yang akan berpengaruh tentunya pada jadwal proyek. Pengaruh pada jadwal proyek tentunya akan berpengaruh pada pendanaan proyek.

d. Potensi minimnya dana. Proyek KT membutuhkan dukungan pinjaman pendanaan yang besar, seperti dukungan pinjaman tanpa bunga dari pemerintah,,tentunya dengan syarat-syarat khusus pada proyek tertentu.

Semua potensi proses dan implikasi konsolidasi tanah tersebut perlu dikaji lebih lanjut bila pada saat mendatang pengembang akan berada dan atau menjadi pelaku pada sistem KT. Pada prinsipnya konsolidasi tanah ini dapat menjadi alternatif bagi pengadaan tanah untuk pengembangan perumahan real estat dengan semangat utamanya adalah kesetaraan peran antara pemilik tanah, pengembang, dan pemerintah daerah serta penerapan prinsip keadilan dalam pengaturan aset negara (baca:tanah) bagi hajat hidup rakyat banyak. Untuk itu memang dibutuhkan political will yang kuat dan itikad yang baik dari setiap pihak yang terlibat di dalam untuk mewujudkan alternatif ini.

Letak keadilan dari proses KT adalah semua pihak (pengembang dan pemilik tanah asal) menanggung beban biaya serta persamaan dalam mendapatkan pertambahan nilai tanah secara proporsional sesuai kontribusinya. Dan pemerintah, dalam hal ini berperan sebagai penjamin keberlangsungan sistem dan pendanaan bagi jaringan infrastruktur primer yang meliputi area perencanaan.

Secara skematis konsep pemikiran penelitian pelaksanaan konsolidasi tanah perkotaan dapat dilihat sebagai berikut : 


\section{Gambar 1. Kerangka Pikir Penelitian}

1. Ps. 33 UUD 45

2. UU 51960 ttg Pokok-pokok Agraria;

3. UU 4/1992 ttg Perumahan dan Permukiman;

4. UU 32/2004 ttg Pemerintahan Daerah,

5. UU 26/2007 ttg Penataan Ruang;

6. PP 16/2004 ttg Penatagunaan Tanah;

7. Peraturan KaBPN Nomor 4 Tahun 1991 tta Konsolidasi Tanah.

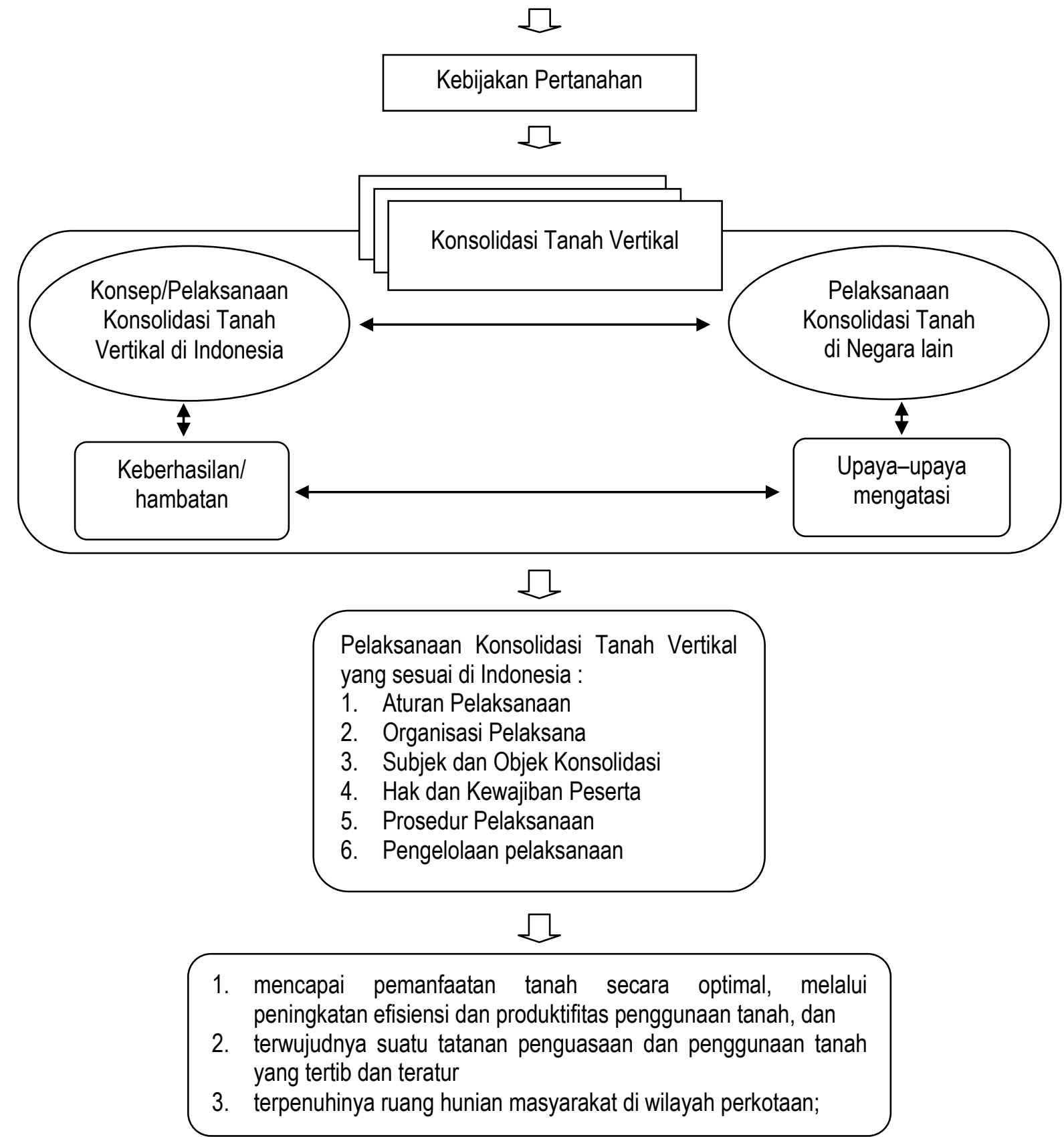




\section{BAB III \\ METODOLOGI PENELITIAN}

\section{A. Lokasi Penelitian}

Lokasi sampel penelitian ditentukan dengan menggunakan metode purposiv (purposive sampling) yaitu Propinsi sample dipilih/ditentukan sebagai lokasi yang merupakan daerah perkotaan, mempunyai jumlah penduduk di atas 1,5 juta dan menjadi sasaran pembangunan rumah susun. Berdasarkan metode tersebut maka lokasi sampel penelitian dipilih dan ditetapkan sebagai berikut :

Tabel 1. Lokasi Penelitian Konsolidasi Tanah Vertikal

\begin{tabular}{|c|l|l|}
\hline No. & \multicolumn{2}{|c|}{ Sampel Penelitian } \\
\hline 1 & Propinsi Sumatera Utara & Kota Medan \\
\hline 2 & Propinsi Sumatera Selatan & Kota Palembang \\
\hline 3 & Propinsi Jawa Barat & Kota Bandung \\
\hline 4 & Propinsi Jawa Tengah & Kota Semarang \\
\hline 5 & Propinsi DI Yogyakarta & Kota Yogyakarta \\
\hline 6 & Propinsi Jawa Timur & Kota Surabaya \\
\hline 7 & Propinsi Kalimantan Selatan & Kota Banjarmasin \\
\hline 8 & Propinsi Sulawesi Selatan & Kota Makassar \\
\hline
\end{tabular}

\section{Unit Penelitian dan Responden.}

Sesuai dengan data yang dibutuhkan dalam penelitian ini maka responden yang ditetapkan sebagai berikut :

Tabel 2. Unit Penelitian dan Jumlah Responden

\begin{tabular}{|c|l|l|c|}
\hline No. & \multicolumn{1}{|c|}{ Lokasi } & \multicolumn{1}{|c|}{ Responden } & Jumlah \\
\hline 1 & Propinsi & Kanwil BPN Propinsi & 8 \\
\hline 2 & Kabupaten/Kota & 1. Kantor Pertanahan Kab/Kota & 8 \\
& & 2. Dinas PU/Perumahan & 8 \\
& & 3. Perumnas & 8 \\
& & 4. Instansi terkait lainnya & 8 \\
\hline 3 & Kelurahan/Desa & $\begin{array}{l}\text { 1. Masyarakat sekitar lokasi yang } \\
\text { berpotensi untuk konsolidasi tanah }\end{array}$ & 8 \\
& & 2. Masyarakat penghuni rusunami/ & 8 \\
& & rusunawa & \\
\hline
\end{tabular}

\section{Pengumpulan Data}

Penelitian ini dilaksanakan dengan mengadakan pengamatan di lokasi pelaksanaan Konsolidasi Tanah dan pembangunan rumah susun yang dilaksanakan di wilayah perkotaan. 


\section{Macam Data}

Penelitian ini memerlukan dua jenis data, yaitu data primer dan data sekunder. Data primer merupakan data yang diambil dari responden terpilih melalui wawancara dengan menggunakan panduan yang telah disediakan. Sedangkan data sekunder merupakan informasi yang diambil dan dikumpulkan dari literatur yang berkaitan dengan konsolidasi tanah vertikal dan informasi dari instansi/kantor terkait dalam penelitian ini.

\section{B. Pengolahan dan Analisis Data}

Data yang diperoleh akan dikompilasi berdasarkan lingkup dan sasaran penelitian, diklasifikasi dan ditabulasi guna memperoleh gambaran/diskriptif pelaksanaan konsolidasi tanah dan pembangunan rumah susun, keberhasilan dan hambatan pelaksanaan, selanjutnya dilakukan pengkajian terhadap faktor penyebab untuk kemudian diupayakan penanganannya.

\section{Definisi Operasional}

1. Konsolidasi Tanah Perkotaan Vertikal adalah kebijaksanaan pertanahan mengenai penataan kembali penguasaan dan penggunaan tanah serta usaha pengadaan tanah untuk kepentingan pembangunan, untuk meningkatkan kualitas lingkungan dan pemeliharaan sumberdaya alam dengan melibatkan partisipasi aktif masyarakat di wilayah perkotaan dengan pendekatan pembangunan perumahan secara vertikal.

2. Peserta kosolidasi tanah adalah pemegang hak atas tanah atau penggarap tanah negara obyek Konsolidasi Tanah.

3. Tanah Obyek Konsolidasi adalah tanah negara non pertanian dan atau tanah hak, di wilayah perkotaan atau pedesaan yang ditegaskan oleh Ka BPN untuk konsolidasi.

4. Sumbangan tanah untuk pembangunan adalah bagian dari obyek Konsolidasi tanah yang disediakan untuk pembangunan prasarana jalan dan fasilitas umum lainnya, serta Tanah Pengganti Biaya Pelaksanaan.

5. Tanah Pengganti Biaya Pelaksanaan adalah bagian dari sumbangan tanah untuk pembangunan yang diserahkan kepada pihak ketiga dengan pembayaran kompensasi berupa uang yang dipergunakan untuk pembiayaan kegiatan pelaksanaan konsolidasi tanah sesuai dengan Daftar Rencana Kegiatan Konsolidasi Tanah (DRKK).

6. Surat Ijin Menggunakan Tanah (SIMT) adalah Surat Ijin Menggunakan Tanah Pengganti Biaya Pelaksanaan yang dikeluarkan oleh Kepala Kantor Pertanahan Kabupaten/Kotamadya. 


\section{BAB IV \\ HASIL PENELITIAN}

\section{A. GAMBARAN UMUM WILAYAH PENELITIAN}

\section{Yogyakarta}

\section{a. Deskripsi Wilayah}

Kota Yogyakarta terletak antara $110^{\circ} 24^{\prime} 19^{\prime \prime}-110^{\circ} 28^{\prime} 53^{\prime \prime}$ Bujur Timur dan antara 07 $49^{\prime} 26^{\prime \prime}-07^{\circ} 15^{\prime} 24^{\prime \prime}$ Lintang Selatan, dengan luas sekitar 32,5 $\mathrm{Km}^{2}$ atau 1,02\% dari luas wilayah Provinsi Daerah Istimewa Yogyakarta. Jarak terjauh dari Utara ke Selatan kurang lebih 7,5 Km dan dari Barat ke Timur kurang lebih 5,6 Km. Secara administratif Kota Yogyakarta terdiri dari 14 kecamatan dan 45 kelurahan dengan batas wilayah :

- Sebelah Utara : Kabupaten Sleman

- Sebelah Timur $\quad$ : Kabupaten Bantul dan Sleman

- Sebelah Selatan : Kabupaten Bantul

- Sebelah Barat $\quad$ : Kabupaten Bantul dan Sleman berikut:

Wilayah Kota Yogayakarta terbagi dalam lima bagian kota dengan pembagian sebagai

Wilayah I : Ketinggian daerah ini $\pm 91 \mathrm{~m}- \pm 117 \mathrm{~m}$ diatas permukaan laut rata-rata. Yang termasuk dalam wilayah ini adalah :

- Sebagian Kecamatan Jetis

- Kecamatan Gedongtengen

- Kecamatan Ngampilan

- Kecamatan Keraton

- Kecamatan Gondomanan

Wilayah II : Ketinggian daerah ini $\pm 97 \mathrm{~m} \mathrm{-} \pm 114 \mathrm{~m}$ diatas permukaan laut rata-rata. Yang termasuk ke dalam wilayah ini adalah:

- Kecamatan Tegalrejo

- Sebagian Kecamatan Wirobrajan

Wilayah III : Ketinggian daerah ini $\pm 102 \mathrm{~m} \mathrm{-} \pm 130 \mathrm{~m}$ diatas permukaan laut rata- rata. Yang termasuk ke dalam wilayah ini adalah:

- Kecamatan Gondokusuman

- Kecamatan Danurejan

- Kecamatan Pakualaman

- Sebagian kecil Kecamatan Umbulharjo 
Wilayah $I V \quad$ : Ketinggian daerah ini $\pm 75 \mathrm{~m}- \pm 102 \mathrm{~m}$ diatas permukaan laut rata-rata. Yang termasuk ke dalam wilayah ini adalah:

- $\quad$ Sebagian Kecamatan Mergangsan

- $\quad$ Kecamatan Umbulharjo

- $\quad$ Kecamatan Kotagedhe

- Kecamatan Mergangsan

Wilayah $V$ : Ketinggian daerah ini $\pm 83 \mathrm{~m} \mathrm{-} \pm 102 \mathrm{~m}$ diatas permukaan laut rata-rata. Yang termasuk ke dalam wilayah ini adalah;

- Kecamatan Wirobrajan

- Kecamatan Mantrijeron

- Sebagian Kecamatan Gondomanan

- $\quad$ Sebagian Kecamatan Mergangsang

Kota Yogyakarta terdiri dari 14 kecamatan, 45 kelurahan, 362 RW dan 2.523 RT dengan luas wilayah $32,5 \mathrm{~km}^{2}$ atau kurang lebih 1,02\% dari luas Wilayah Propinsi Daerah Istimewa Yogyakarta.

\section{b. Kepadatan Penduduk}

Jumlah penduduk di Kota Yogyakarta dari tahun ke tahun terus mengalami peningkatan dari faktor kelahiran, datang, kamatian dan pergi. Berdasarkan data BPS tahun 2010, penduduk Kota Yogyakarta berjumlah 388.088 orang yang terdiri 48,95 persen penduduk laki-laki dan 51,05 persen perempuan. Dengan luas wilayah $32,50 \mathrm{~km}^{2}$, kepadatan penduduk Kota Yogyakarta 13.881 jiwa per $\mathrm{km}^{2}$.

Tabel 3. Kepadatan Penduduk Kota Yogyakarta

\begin{tabular}{|l|c|c|c|c|c|}
\hline \multicolumn{1}{|c|}{ Kecamatan } & $\begin{array}{c}\text { Luas } \\
\text { Wilayah }\end{array}$ & $\begin{array}{c}\text { Laki- } \\
\text { Laki }\end{array}$ & Perempuan & Jumlah & $\begin{array}{c}\text { Kepadatan } \\
\text { Penduduk }\end{array}$ \\
\hline Mantrijeron & 2.61 & 18,398 & 19,044 & 37,442 & 14,346 \\
Kraton & 1.40 & 10,612 & 11,908 & 22,520 & 16,086 \\
Mergangsan & 2.31 & 17,352 & 18,569 & 35,921 & 15,550 \\
Umbulharjo & 8.12 & 39,191 & 40,129 & 79,320 & 9,768 \\
Kotagede & 3.07 & 16,097 & 16,207 & 32,304 & 10,522 \\
Gondokusuman & 3.99 & 27,062 & 28,648 & 55,710 & 13,962 \\
Danurejan & 1.10 & 10,999 & 11,683 & 22,682 & 20,620 \\
Pakualaman & 0.63 & 5,754 & 6,014 & 11,768 & 18,679 \\
Gondomanan & 1.12 & 7,398 & 8,595 & 15,993 & 14,279 \\
Ngampilan & 0.82 & 9,537 & 10,695 & 20,232 & 24,673 \\
Wirobrajan & 1.76 & 15,856 & 15,248 & 31,104 & 17,673 \\
Gedongtengen & 0.96 & 9,708 & 10,714 & 20,422 & 21,273 \\
Jetis & 1.70 & 15,019 & 15,442 & 30,461 & 17,918 \\
Tegalrejo & 2.91 & 20,244 & 20,792 & 41,036 & 14,102 \\
\hline \multicolumn{1}{|c|}{ Jumlah } & $\mathbf{3 2 . 5 0}$ & $\mathbf{2 2 3 , 2 2}$ & $\mathbf{7 2 3 3 , 6 8 8}$ & $\mathbf{4 5 6 , 9 1 5}$ & $\mathbf{1 4 , 0 5 9}$ \\
\hline
\end{tabular}

Sumber : BPS Kota Yogyakarta 
Dari tabel di atas, terlihat bahwa tingkat kepadatan penduduk tertinggi berada di wilayah kecamatan Gondomanan, kedua adalah wilayah kecamatan Wirobrajan, dan ketiga adalah kecamatan Gondokusuman.

\section{c. Status Tanah}

Status tanah yang ada di Di Yogyakarta, antara lain :

- Tanah bekas Swapraja yaitu tanah Sultan Ground dan Paku Alaman Ground,

- Tanah bekas Milik Adat, yang berasal dari kas Desa;

- Hak Milik (bekas agrarisch eigendom)

- Hak Guna Bangunan

- Hak Pakai yang diberikan kepada perorangan dan Instansi pemerintah selama diperlukan

- Hak Pengelolaan

Adapun jenis penguasaan/pemilikan tanah yang sudah bersertipikat di Yogyakarta, antara lain :

Tabel 4. Jenis Penguasaan/Pemilikan Tanah

\begin{tabular}{|c|l|c|}
\hline No. & \multicolumn{1}{|c|}{ Jenis Penguasaan/Pemilikan Tanah } & Jumlah (bidang) \\
\hline 1. & Hak Milik & 68.226 \\
\hline 2. & Hak Guna bangunan & 18.254 \\
\hline 3. & Hak Pakai & 7.302 \\
\hline 4. & Hak Pengelolaan & 10 \\
\hline
\end{tabular}

\section{d. Penggunaan Tanah}

Jenis penggunaan tanah di Kota Yogyakarta pada tahun 2010 didominasi pemanfataan untuk pemukiman/perumahan sekitar $64,8 \%$ (2.106 ha) kemudian diikuti oleh penggunaan lainlain 11,9\% (388 ha), perusahaan 8,5\% (277 ha), jasa 8,4\% (275 ha), pertanian $4 \%$ (130 ha) dan industri $1,6 \%$ (52 ha). 
Tabel 5. Penggunaan Lahan menurut Kecamatan di Kota Yogyakarta 2008

\begin{tabular}{|c|c|c|c|c|c|c|c|c|}
\hline \multirow[b]{2}{*}{$\begin{array}{c}\text { Kecamatan } \\
\text { District }\end{array}$} & \multicolumn{7}{|c|}{ Jenis Penggunaan Lahan/Type of Land Utilization $(\mathrm{Ha})$} & \multirow[b]{2}{*}{$\begin{array}{c}\text { Jumlah } \\
\text { Total }\end{array}$} \\
\hline & $\begin{array}{c}\text { Perumahan } \\
\text { Dwelling }\end{array}$ & $\begin{array}{l}\text { Jasa } \\
\text { Service }\end{array}$ & \begin{tabular}{|c|} 
Perush. \\
Establish \\
ment
\end{tabular} & $\begin{array}{c}\text { Industri } \\
\text { Indus } \\
\text { try }\end{array}$ & $\begin{array}{c}\text { Pertanian } \\
\text { Agri } \\
\text { culture }\end{array}$ & $\begin{array}{c}\text { Non } \\
\text { Produktif }\end{array}$ & $\begin{array}{l}\text { Lain-lain } \\
\text { Others }\end{array}$ & \\
\hline$(1)$ & $(2)$ & $(3)$ & \begin{tabular}{|l|}
$(4)$ \\
\end{tabular} & $(5)$ & \begin{tabular}{|c|} 
cinme \\
$(6)$ \\
\end{tabular} & (7) & (8) & (9) \\
\hline 1. Mantrijeron & 200.563 & 9.225 & 12.976 & 0.488 & 4.431 & 0.019 & 33.226 & 261 \\
\hline 2. Kraton & 104.458 & 11.200 & 8.350 & 0.000 & 0.000 & 0.000 & 15.993 & 140 \\
\hline 3. Mergangsan & 156.495 & 15.958 & 19.838 & 1.600 & 5.161 & 0.124 & 31.825 & 231 \\
\hline 4. Umbulharjo & 508.812 & 52.521 & 36.148 & 17.880 & 75.167 & 16.431 & 105.041 & 812 \\
\hline 5. Kotagede & 221.733 & 8.560 & 17.178 & 10.646 & 17.608 & 0.996 & 30.279 & 307 \\
\hline 6. Gondokusuman & 227.518 & 69.160 & 58.911 & 6.340 & 0.029 & 0.415 & 36.628 & 399 \\
\hline 7. Danurejan & 49.812 & 16.960 & 30.243 & 0.320 & 0.000 & 0.000 & 12.665 & 110 \\
\hline 8. Pakualaman & 34.598 & 11.040 & 5.750 & 0.320 & 0.000 & 0.320 & 10.973 & 63 \\
\hline 9. Gondomanan & 46.537 & 29.538 & 22.592 & 1.520 & 0.000 & 0.000 & 11.813 & 112 \\
\hline 10. Ngampilan & 62.225 & 3.360 & 4.179 & 0.000 & 0.000 & 0.480 & 11.757 & 82 \\
\hline 11. Wirobrajan & 136.408 & 7.230 & 14.764 & 0.600 & 0.565 & 0.000 & 16.433 & 176 \\
\hline 12. Gedongtengen & 66.075 & 3.680 & 15.213 & 0.000 & 0.000 & 0.000 & 11.033 & 96 \\
\hline 13. Jetis & 105.899 & 18.249 & 22.860 & 2.880 & 0.000 & 0.545 & 19.567 & 170 \\
\hline J u m I a h & $2,106.338$ & 275.562 & 277.565 & 52.23413 & 30.029 & 20.041 & 388.160 & 3,250 \\
\hline 2007 & $2,104.357$ & 275.467 & 275.617 & 52.23413 & 34.052 & 20.113 & 388.160 & 3,250 \\
\hline
\end{tabular}

Sumber Data : BPN Kota Yogyakarta

Data di atas menunjukkan wilayah yang paling tinggi penggunaan untuk perumahan adalah kecamatan Umbulharjo, Gondokusuman dan Kotagede. Sedangkan pengunaan tanah untuk jasa tertinggi di wilayah kecamatan Gondokusuman,kedua adalah wilayah kecamatan Umbulharjo dan ketiga berada di wilayah Gondomanan. 


\section{e. Pelaksanaan Konsolidasi tanah}

\section{1) Horizontal}

Konsolidasi tanah perkotaan di Daerah Istimewa Yogyakarta dilaksanakan oleh Kanwil BPN dan dibiayai oleh Dipa BPN-RI yang bersumber dari APBN dan swadaya masyarakat melalui PNBP.

Tabel 6. Lokasi Konsolidasi Tanah Perkotaan di Prop. DI Yogyakarta

\begin{tabular}{|c|c|c|c|c|c|}
\hline No & Lokasi & $\begin{array}{c}\text { Tahun } \\
\text { Pelaksanaan }\end{array}$ & Luas (Ha) & $\begin{array}{l}\text { Jumlah } \\
\text { Bidang }\end{array}$ & Keterangan \\
\hline 1 & Banguntapan, Bantul & 1997-1998 & 0,5163 & 25 & swadaya \\
\hline 2 & Banguntapan, Bantul & 1997-1998 & 0,4805 & 25 & swadaya \\
\hline 3 & Banguntapan, Bantul & 1997-1998 & 0,3490 & 21 & swadaya \\
\hline 4 & Depok, Sleman & 1997-1998 & 0,2118 & 12 & swadaya \\
\hline 5 & Ngaglik, S;eman & 1997-1998 & 0,1721 & 10 & swadaya \\
\hline 6 & Ngaglik, S;eman & 1998-1999 & 0,3060 & 18 & swadaya \\
\hline 7 & Kalasan, Sleman & 1998-1999 & 2,7988 & 62 & swadaya \\
\hline 8 & Kasihan, Bantul & 1998-1999 & 1,2176 & 46 & swadaya \\
\hline 9 & Banguntapan,Bantul & 1998-1999 & 0,2518 & 8 & swadaya \\
\hline 10 & Sewon, Bantul & 1998-1999 & 0,1182 & 12 & swadaya \\
\hline 11 & Ngemplak, Sleman & 1999-2000 & 0,9910 & 33 & swadaya \\
\hline 12 & Ngemplak, Sleman & $1999-2000$ & 2,2262 & 72 & swadaya \\
\hline 13 & Ngemplak, Sleman & 1999-2000 & 0,5178 & 30 & swadaya \\
\hline 14 & Rongkop, Gunungkidul & $1999-2000$ & 5,5118 & 47 & swadaya \\
\hline 15 & Banguntapan,Bantul & 2009 & 2,0418 & 87 & swadaya \\
\hline 16 & Sanden, Bantul & 2009 & 15,4364 & 300 & APBN \\
\hline
\end{tabular}

Data tersebut di atas menunjukkan bahwa konsolidasi tanah horizontal belum pernah dilaksanakan di Kota Yogyakarta, dan sebagian besar konsolidasi tanah horizontal di Provinsi Daerah Istimewa Yogyakarta di laksanakan secara swadaya.

\section{2) Vertikal}

\section{a. Kebijakan}

Kebijakan yang berkaitan dengan pengembangan konsep konsolidasi tanah dengan pendekatan pembangunan perumahan secara vertikal belum ada di provinsi Yogyakarta. Yang sudah dilaksanakan adalah pembangunan rumah susun dengan konsep rumah susun sewa. Rumah susun sederhana milik belum ada karena Peraturan Daerah yang menjabarkan PP No. 4 tahun 1988 tentang Rumah Susun, sampai saat ini belum dimiliki oleh Pemerintah Daerah Provinsi DIY dan Pemerintah Daerah Kabupaten/Kota di wilayah DIY, sehingga landasan hukum yang digunakan bersifat pedoman yang dikeluarkan dalam bentuk keputusan Walikota. 
Tabel 7. Lokasi Pembangunan Rusunawa di Kota Yogyakarta

\begin{tabular}{|c|c|c|c|c|c|c|c|c|c|c|c|c|}
\hline No. & Lokasi & Luas & Status & $\begin{array}{l}\text { Sumber } \\
\text { dana }\end{array}$ & $\begin{array}{c}\text { Jumlah dana } \\
\text { (Rp) }\end{array}$ & $\begin{array}{c}\text { Jumlah } \\
\text { unit }\end{array}$ & $\begin{array}{c}\text { Sewa } \\
\text { (Rp) }\end{array}$ & Terhuni & $\begin{array}{c}\text { Dasar } \\
\text { penghunian }\end{array}$ & $\begin{array}{c}\text { Asal } \\
\text { penghuni }\end{array}$ & $\begin{array}{l}\text { Penghasilan } \\
\text { penghuni }\end{array}$ & Pengelola \\
\hline 7 & $\begin{array}{l}\text { Danurejan, } \\
\text { Suryatmajan, } \\
\text { Kota Yogjakarta }\end{array}$ & $\begin{array}{l}0,3 \\
\mathrm{Ha}\end{array}$ & Pemda & $\begin{array}{l}\text { APBN } \\
\text { (Dept. } \\
\text { PU) } \\
/ 2004-5\end{array}$ & 7.000 .000 .000 & 72 unit & RP.70.000,- & $\begin{array}{l}100 \% \\
\text { terhuni }\end{array}$ & SK Walikota & $\begin{array}{l}100 \% \\
\text { penduduk } \\
\text { Kota } \\
\text { Yogjakarta }\end{array}$ & $<1,5$ juta & $\begin{array}{l}\text { Badan } \\
\text { Pengelola } \\
\text { Rusunawa } \\
\text { Cokrodirjan } \\
\text { (masyarakat) }\end{array}$ \\
\hline 8 & $\begin{array}{l}\text { Danurejan, } \\
\text { Tegalpanggung, } \\
\text { Kota Yogjakarta }\end{array}$ & $\begin{array}{l}0,1 \\
\mathrm{Ha}\end{array}$ & $\begin{array}{l}\text { Milik } \\
\text { Pemkot }\end{array}$ & $\begin{array}{l}\text { APBN } \\
\text { (Dept. } \\
\text { PU)/2008 }\end{array}$ & 7.812 .600 .000 & 68 unit & $\begin{array}{l}\text { Lt.2:185.000 } \\
\text { Lt. } 3: 175.000 \\
\text { Lt.4 } \\
165.000\end{array}$ & $\begin{array}{l}10 \text { unit } \\
\text { lantai } \\
\text { dasar }\end{array}$ & SK Walikota & $\begin{array}{l}100 \% \\
\text { penduduk } \\
\text { Kota } \\
\text { Yogjakarta }\end{array}$ & $<1,5$ juta & $\begin{array}{l}\text { Badan } \\
\text { Pengelola } \\
\text { Rusunawa } \\
\text { Tegalpanggung } \\
\text { (masyarakat) }\end{array}$ \\
\hline 9 & $\begin{array}{l}\text { Jetis, } \\
\text { Gowongan, } \\
\text { Kota Yogjakarta }\end{array}$ & $\begin{array}{l}0,27 \\
\mathrm{Ha}\end{array}$ & $\begin{array}{l}\text { Milik } \\
\text { Pemda }\end{array}$ & $\begin{array}{c}\text { APBN } \\
\text { (Dept. } \\
\text { PU)/2007 }\end{array}$ & 7.466 .000 .000 & $\begin{array}{l}96 \text { unit } \\
\text { (1 twin } \\
\text { block) }\end{array}$ & $\begin{array}{l}\text { Lt1 : } 74.569 \\
\text { (10\%xUMP) } \\
\text { Lt2 : } 67.112 \\
\text { (9\% x UMP) } \\
\text { Lt3 : } 59.656 \\
\text { (8\% x UMP) } \\
\text { Lt4 : } 52.199 \\
(7 \% \text { x UMP) }\end{array}$ & $\begin{array}{l}100 \% \\
\text { terhuni }\end{array}$ & $\begin{array}{l}\text { SK Gubenur } \\
\text { DIY }\end{array}$ & $\begin{array}{l}100 \% \\
\text { penduduk } \\
\text { Kota } \\
\text { Yogjakarta, }\end{array}$ & $\begin{array}{l}750 \text { ribu }- \\
2,5 \text { juta }\end{array}$ & $\begin{array}{l}\text { UPTD/Disnakert } \\
\text { rans Prov.DIY }\end{array}$ \\
\hline 10 & $\begin{array}{l}\text { Jetis, } \\
\text { Gowongan, } \\
\text { Kota Yogjakarta }\end{array}$ & $\begin{array}{l}0,25 \\
\mathrm{Ha}\end{array}$ & $\begin{array}{l}\text { Milik } \\
\text { Pemda }\end{array}$ & $\begin{array}{c}\text { APBN } \\
\text { (Dept. } \\
\text { PU)/2008 }\end{array}$ & 7.320 .000 .000 & $\begin{array}{l}96 \text { unit } \\
\text { (1 twin } \\
\text { block) }\end{array}$ & $\begin{array}{l}\text { Lt1 : } 74.569 \\
\text { (10\%xUMP) } \\
\text { Lt2 : } 67.112 \\
\text { (9\% x UMP) } \\
\text { Lt3 : } 59.656 \\
\text { (8\% x UMP) } \\
\text { Lt4 : } 52.199 \\
\text { (7\% x UMP) }\end{array}$ & $\begin{array}{l}54 \text { unit } \\
\text { (rencana } \\
82 \text { unit) }\end{array}$ & $\begin{array}{l}\text { SK Gubenur } \\
\text { DIY }\end{array}$ & $\begin{array}{l}100 \% \\
\text { penduduk } \\
\text { Kota } \\
\text { Yogjakarta, }\end{array}$ & $\begin{array}{l}750 \text { ribu }- \\
2,5 \text { juta }\end{array}$ & $\begin{array}{l}\text { UPTD/Disnakert } \\
\text { rans Prov.DIY }\end{array}$ \\
\hline
\end{tabular}

Sumber data : Kimpraswil DI Yogyakarta 
Dari ke empat Rusunawa yang terdapat di Kota Yogyakarta tersebut, Rusunawa Tegal Panggung telah melakukan kombinasi konsolidasi tanah horizontal dan konsolidasi tanah vertikal. Pada kasus ini, $10 \mathrm{KK}$ awalnya tinggal di lokasi ini yang tanahnya merupakan tanah milik Pemda Kota Yogyakarta. Ketika rusunawa dibangun mereka mendapatkan prioritas untuk menempati. Kini mereka menjadi penghuni Rusunawa Tegal Panggung dan berada di Lantai 1, dengan status Hak Pakai dan dapat diwariskan.

Hal ini hanya berlaku untuk ke 10 orang tersebut karena Pemerintah kota telah menetapkan jangka waktu mereka untuk dapat tinggal di rusunawa tersebut. Rusunawa tidak diperuntukan sebagai tempat tinggal seumur hidup bagi tiap penyewa. Jangka waktu 3-6 tahun dianggap maksimal bagi masyarakat untuk dapat menaikkan taraf hidup mereka. Pemerintah hanya memfasilitasi untuk sementara waktu. Setelah 6 tahun tinggal di rusunawa tersebut, masyarakat dianggap telah mapan dan mampu untuk menyewa rumah yang lebih baik lagi.

Besaran uang sewa dari penghuni lama yang mendapat prioritas tersebut berbeda dengan penyewa lainnya, karena mereka hanya dikenakan sewa sebesar Rp 5.000,- per bulan. Sedangkan penyewa lainnya dikenakan tarif berbeda untuk tiap lantai, untuk lantai II dikenakan Rp 185.000,- per bulan, lantai III dikenakan Rp 175.000,- per bulan, dan lantai IV sebesar Rp. 165.000,- per bulan. Rusunawa terdiri dari 4 lantai. Lantai dasar dibuat taman kanak-kanak, balai serba guna, ruang ME (Machine and Engineering) untuk pengendalian listrik dan air, tempat bermain anak-anak, kantor pengelola dan tempat parkir. Ini merupakan ruang bersama yang akan dijadikan tempat penghuni rusun bergaul bersama. Sementara itu, ketiga lantai lainnya diisi oleh unit-unit hunian yang disewakan. Di setiap unit tersedia kamar mandi, toilet, dapur, tempat jemuran, kamar dan ruang keluarga. Fasilitas yang lazim terdapat di setiap rumah.

\section{b. Kondisi Lingkungan Pemukiman}

Sebagian besar kurang teratur yang merupakan lingkungan padat dengan kualitas bangunan sebagian besar rumah permanen dengan jalan yang sempit, sebagian besar menguasai/memilik tanah kurang atau sama dengan $100 \mathrm{~m} 2$.

\section{Semarang}

\section{a. Deskripsi Wilayah}

Kota Semarang terletak antara garis $6^{\circ} 50^{\prime}-7^{\circ} 10$; Lintang Selatan dan garis $109^{\circ} 35^{\prime}$ $110^{\circ} 50^{\prime}$ Bujur Timur. Dibatasi sebelah Barat dengan Kabupaten Kendal, sebelah Timur dengan Kabupaten Demak, sebelah Selatan dengan kabupaten Semarang dan sebelah Utara dibatasi oleh Laut Jawa dengan panjang garis pantai meliputi 13,6 Km. Ketinggian Kota Semarang terletak antara 0,75 sampai dengan 348,00 di atas garis pantai. Secara administratif, kota Semarang terbagi atas 16 wilayah kecamatan dan 177 Kelurahan. Luas wilayah Kota Kemarang tercatat $373,70 \mathrm{Km}^{2}$. Kecamatan yang paling luas wilayahnya adalah kecamatn Mijen $\left(57,55 \mathrm{Km}^{2}\right.$ ), diikuti oleh kecamatan Gunungpati dengan luas wilayahnya sebesar 52,63 $\mathrm{Km}^{2}$, sedangkan kecamatan yang terkecil wilayahnya adalah kecamatan Semarang Tengah $\left(5,14 \mathrm{Km}^{2}\right)$. 


\section{b. Kepadatan Penduduk}

Berdasarkan hasil registrasi penduduk tahun 2008, jumlah penduduk Kota Semarang tercatat sebesar 1.481.640 jiwa dengan pertumbuhan penduduk selama tahun 2008 sebesar $1,85 \%$. Kondisi tersebut memberi arti bahwa pembangunan kependudukan, khususnya usaha untuk menurunkan jumlah kelahiran, memberikan hasil yang nyata.

Sekitar 74,01\% penduduk Kota Semarang berumur produktif (15-64) th, sehingga angka beban tanggungan, yaitu perbandingan antara penduduk usia tidak produktif (0-14 dan 65 th keats) pada tahun 2008 sebesar 32,16 yang berarti 100 orang penduduk usia produktif menanggung 32 orang penduduk usia tidak produktif.

Dalam kurun waktu 5 tahun (2004-2008), kepadatan penduduk cenderung naik seiring dengan kanaikan jumlah penduduk. Di sisi lain, penyebaran penduduk di masing-masing kecamatan belum merata. Di wilayah Kota Semarang, tercatat kecamatan Semarang/Tengah sebagai wilayah terpadat, sedangkan kecamatan Mijen merupakan wilayah yang kepadatannya paling rendah.

Tabel 8. Banyaknya Penduduk di Kota Semarang

\begin{tabular}{|c|c|c|c|c|}
\hline \multirow{3}{*}{\multicolumn{2}{|c|}{$\begin{array}{c}\text { Kecamatan/ } \\
\text { District }\end{array}$}} & \multicolumn{3}{|c|}{$\frac{\text { Banyaknya Pendduk Mnrt Warga Negara }}{\text { WNI }+ \text { WNA }}$} \\
\hline & & $\begin{array}{c}\text { Laki-Lakil } \\
\text { Male }\end{array}$ & $\begin{array}{l}\text { Perempuan' } \\
\text { Female }\end{array}$ & $\begin{array}{c}\text { Jumłah/ } \\
\text { Tozal }\end{array}$ \\
\hline & & $(8)$ & (9) & $(10)$ \\
\hline 010. Mijen & & 24.804 & 24.119 & 48.923 \\
\hline 020. Gunungpati & & 32.720 & 32.745 & 65.465 \\
\hline 030. Banyumanik & & 60.616 & 61.239 & 121.855 \\
\hline 040. Gajah Mungkur & & 30.942 & 30.726 & 61.668 \\
\hline 0S0. Smg. Selatan & & 42.839 & 42.752 & 85.591 \\
\hline 060. Candissuri & & 38.380 & 39.557 & 77.937 \\
\hline 070. Tembalang & & 64.127 & 62.881 & 127.008 \\
\hline 080. Pedurungan & & 81.242 & 82.320 & 163.562 \\
\hline 090. Genuk & & 40.219 & 40.381 & 80.600 \\
\hline 100. Gayamsari & & 35.010 & 35.772 & 70.782 \\
\hline 110. Smg. Timur & & 40.047 & 41.700 & 81.747 \\
\hline 120. Sung. Utara & & 61.366 & 65.399 & 126.765 \\
\hline 130. Smg. Tengah & & 36.086 & 38.142 & 74.228 \\
\hline 140. Smg. Barat & & 79.076 & 80.349 & 159.425 \\
\hline 150. TUGU & & 13,449 & 13.527 & 26.976 \\
\hline 160. Nealiyan & & 54.534 & 54.574 & 109.108 \\
\hline Jumlah/Tonal & 2008 & 735.457 & 746.183 & 1.481 .640 \\
\hline & 2007 & 722.026 & 732.568 & 1.454 .594 \\
\hline & 2006 & 711.755 & 722.270 & 1.434 .025 \\
\hline & 2005 & 705.627 & 713.851 & 1.419 .478 \\
\hline & 2004 & 695.676 & 703.457 & 1.399 .133 \\
\hline
\end{tabular}

Sumber : BPS Kota Semarang 2008

\section{c. Status Tanah}

Tidak ada data 


\section{d. Penggunaan Tanah}

Jenis penggunaan tanah di Kota Semarang pada tahun 2010 didominasi pemanfaatan tanah yang digunakan untuk pemukiman/perumahan sekitar 14.948 ha, kemudian diikuti oleh pertanian sebesar 11.584,7 ha, dan penggunaan lain sebesar $10.837,3$ ha.

\section{e. Pelaksanaan Konsolidasi Tanah}

\section{1) Horizontal}

Kegiatan Konsolidasi Tanah Perkotaan di Propinsi Jawa Tengah yang pelaksanaannya oleh Kanwil BPN Pop. Jawa Tengah dan Kantor Pertanahan Kab/Kota, dilaksanakan di 21 Kabupaten dengan luas 391,451 $\mathrm{M}^{2}$ sebanyak 1,954 bidang. Kegiatan ini dibiayai oleh APBN dan Swadaya Masyarakat dalam Dipa BPN-RI 2009 melalui PNBP.

Kegiatan Konsolidasi tanah Perkotaan meliputi : Penjajakan likasi, Penyuluhan , Penetapan lokasi, Identifikasi Subyek dan Obyek, Pengukuran dan pemetaan keliling, Pengukuranrincikan bidang tanah, Pemetaan topografi, pemetaan penggunaan tanah, Penyusunan blok plan/pra desain tata ruang, Penegasan kembali sebagai obyek konsolidasi tanah, Pengukuran Staking out, Penerbitan SK Pemberian HAT, dan Penerbitan sertipikat.

Konsolidasi Tanah Perkotaan ini merupakan salah satu usaha untuk mewujudkan/menerapkan Rencana Detail Tata Ruang Kota Semarang, utamanyadalam rangka menata kembali kawasan permukiman melalui penataan kembali pemilikan, penguasaan dan penggunaan tanah.

Konsolidasi Tanah Perkotaan di Propinsi Jawa Tengah khususnya di Kota Semarang pelaksanaannya sebagian besar merupakan pelaksanaan pengkaplingan tanah untuk permukiman (rumah tinggal) yang semula dimiliki/dikuasai oleh beberapa orang saja kemudian dikapling untuk perumahan (lihat tabel berikut) yang luasannya dengan memperhatikan ketentuan dalam Keputusan Gubernur KDH Tk. I Jawa Tengah No. 11/1998 tanggal 1-8-1998 tentang Pedoman Teknis Perencanaan Perpetakan dan Perda No. 11/2004 tanggal 1-8-2004 tentang Garis Sempadan.

Tabel 9. Luas dan jumlah bidang/peserta dalam pelaksanaan konsolidasi tanah perkotaan di Kota Semarang tahun 2009

\begin{tabular}{|c|l|c|c|c|}
\hline No & \multicolumn{1}{|c|}{ Lokasi Konsolidasi } & Luas (M⿻丷木 $\left.{ }^{2}\right)$ & Penguasaan Asal & Setelah Konsolidasi \\
\hline 1 & Kel. Kalipuncur, Ngaliyan, Semarang & 2.009 & 3 bidang/orang & 27 bidang/peserta \\
\hline 2 & Kel. Kramas, Tembalang, Semarang & 11.220 & 7 bidang/orang & 67 bidang/peserta \\
\hline 3 & Kel. Bulusan, Tembalang, Semarang & 27.670 & 10 bidang/orang & 142 bidang/peserta \\
\hline 4 & Kel. Kedungmundu, Tembalang, Semarang & 6.120 & 1 bidang/orang & 30 bidang/peserta \\
\hline 5 & Kel. Wates, Ngaliyan, Semarang & 14.839 & 3 bidang/orang & 150 bidang/peserta \\
\hline
\end{tabular}




\section{2) Vertikal}

\section{a. Kebijakan}

Konsolidasi Tanah secara vertikal secara khusus belum pernah dilaksanakan di Kota Semarang. Yang banyak dilaksanakan adalah program pembangunan rumah susun yang dikenal dengan program 1000 tower. Program ini memang dialokasikan untuk masyarakat dengan penghasilan menengah dan berpenghasilan tetap. Bagi yang berhak, akan ada subsidi uang muka dan subsidi bunga.

Tabel 10. Lokasi Pembangunan Rusun/Rusunawa di Kota Semarang, Propinsi Jawa Tengah

\begin{tabular}{|c|c|c|c|c|c|c|c|}
\hline No. & Nama & Lokasi & Type & $\begin{array}{c}\text { Jumlah } \\
\text { Unit }\end{array}$ & $\begin{array}{l}\text { Luas } \\
\text { Bangunan }\end{array}$ & $\begin{array}{l}\text { Luas } \\
\text { Tanah }\end{array}$ & Keterangan \\
\hline 1 & $\begin{array}{l}\text { Rusun Plamongansari } \\
\text { Blok A-K, 2lt }\end{array}$ & $\begin{array}{l}\text { Plamongansari } \\
\text { Pedurungan }\end{array}$ & 27 & 208 & 5618 & 9800 & Sewa \\
\hline 2 & $\begin{array}{l}\text { Rusun Karangroto Blok } \\
\text { A 26, B } 24 \text { Unit }\end{array}$ & Karangroto, Genuk & 27 & 50 & 1999 & 3250 & Sewa \\
\hline 3 & $\begin{array}{l}\text { Rusun Karangroto Blok } \\
\mathrm{C}, 2 \text { Unit, } 2 \text { It }\end{array}$ & Karangroto, Genuk & 27 & 104 & 1993 & 2808 & Sewa \\
\hline 4 & $\begin{array}{l}\text { Rusun } \quad \text { Gayamsari } 1 \\
\text { Blok }\end{array}$ & $\begin{array}{l}\text { Tlogomulyo } \\
\text { Pedurungan }\end{array}$ & 27 & 20 & 540 & 1200 & Sewa \\
\hline 5 & $\begin{array}{l}\text { Rusun Bandarharjo I } \\
1 \text { blok } 4 \text { lantai }\end{array}$ & $\begin{array}{l}\text { Bandarharjo } \\
\text { Semarang Utara }\end{array}$ & $\begin{array}{l}27 \\
36 \\
54\end{array}$ & 30 & 1008 & 779 & Sewa \\
\hline 6 & $\begin{array}{l}\text { Rusun Bandarharjo I } \\
1 \text { blok } 4 \text { lantai }\end{array}$ & $\begin{array}{l}\text { Bandarharjo } \\
\text { Semarang Utara }\end{array}$ & $\begin{array}{l}27 \\
36\end{array}$ & 180 & 5184 & 3774 & Sewa \\
\hline 7 & $\begin{array}{l}\text { Rusun Pekunden } 5 \\
\text { blok } 4 \text { lantai }\end{array}$ & $\begin{array}{l}\text { Pekunden } \\
\text { Semarang Tengah }\end{array}$ & $\begin{array}{l}27 \\
54 \\
81\end{array}$ & 118 & & & Rusun milik \\
\hline 8 & Pondok Boro Trimulyo & Trimilyo, Genuk & 18 & 12 & 216 & 1329 & sewa \\
\hline 9 & $\begin{array}{lr}\text { Rusun } & \text { Kaligawe, } \\
\text { Sawahbesar, } & \text { Kec. } \\
\text { Gayan Sari 1989 } & \\
\end{array}$ & $\begin{array}{l}\text { Kaligawe, } \\
\text { Sawahbesar, Kec. } \\
\text { Gayam Sari }\end{array}$ & $\begin{array}{l}24 \\
27\end{array}$ & 672 & 21000 & & $\begin{array}{l}\text { Ex bengkok, } \\
\text { milik Pemda }\end{array}$ \\
\hline
\end{tabular}

Sumber: Pengolahan data Kota Semarang 2010

Rusun Kaligawe, Sawahbesar, Kec. Gayan Sari (sejak 1989) akan diperuntukkan 672 KK terutama bagi warga Tambakan yang terkena Proyek Waduk Jatibarang, 264 orang dan warga yang terkena program pengembangan jalan arteri utara (Semarang Nort Ringroad) 30 orang untuk masyarakat umum dengan proses seleksi.

Yang mirip dengan Konsolidasi Tanah Vertikal adalah Rumah Susun Pekunden Di Semarang Tengah, Kota Semarang. Pembangunan Rusun Pekunden merupakan Pelaksanaan Program Penataan Permukiman di tengah perkotaan Pemerintah Kota Semarang membangun Rumah Susun Pekunden pada tahun 1991 yang lokasinya di belakang Balai Kota Semarang dengan Sistim "Membangun Tanpa Menggusur" karena penghuninya adalah warga pemilik rumah yang terkena proyek.

Pembangunan Rusun Pekunden, dimaksudkan untuk menata kembali permukiman yang sudah ada tetapi tidak layak huni ditengah perkotaan dan mayoritas penghuninya warga ekonomi lemah. Pembangunan rusun diawali dengan kesepakatan Pemkot dengan masyarakat penghuni dengan perjanjian bahwa tanah dan bangunan masyarakat yang berdomisili di lingkungan tersebut dinilai sesuai dengan kondisi existing yang ada. Masing-masing diberikan 
kompensasi sesuai dengan nilai tanah dan bangunan tersebut, namun tidak diberikan dalam bentuk uang tetapi sebagai uang muka untuk mendapatkan unit satuan atas rumah susun yang akan dibangun sesuai proporsi nilai tanah yang sudah disepakati oleh seluruh penghuni yang ada.

Tabel 11. Nilai kompensasi tanah dan bangunan masyarakat penghuni

\begin{tabular}{|c|c|c|}
\hline No. & Nama & Nilai Kompensasi \\
\hline 1 & Mislah Mardiyanto & Rp. 11.804.000,- \\
\hline 2 & Amat Salim/lr. Dadik Tafiono & Rp. 3.958.300,- \\
\hline 3 & Hartono & Rp. 4.588.750,- \\
\hline 4 & Suatmi, MS & Rp. 17.440.500,- \\
\hline 5 & M. Ashari & Rp. 12.224.400,- \\
\hline 6 & Supriyambodo & Rp. 4.588.750,- \\
\hline 7 & Nunuk Priharti & Rp. 4.588.750,- \\
\hline 8 & E. Pujiastuti & Rp. 3.294.000,- \\
\hline 9 & Dwi Haryanto & Rp. 3.294.000,- \\
\hline 10 & Sri Partini & Rp. 1.044.000,- \\
\hline 11 & Rumiyatun & Rp. 1.200.000,- \\
\hline 12 & Samija & Rp. 2.452.875,- \\
\hline 13 & Agus Waluya & Rp. 2.452.875,- \\
\hline 14 & Munirah & Rp. 8.622.800,- \\
\hline 15 & Samian Karyono & Rp. 3.000.000,- \\
\hline 16 & Rakimah & Rp. 3.080.400,- \\
\hline 17 & Sri Wahyuni & Rp. $\quad 570.400,-$ \\
\hline 18 & Sunarno & Rp. 1.171.000,- \\
\hline 19 & Suharti Masinem & Rp. 1.500.000,- \\
\hline 20 & Suryahman & Rp. 3.502.500,- \\
\hline 21 & Mardiono & Rp. 3.677.900,- \\
\hline 22 & Ponirah & Rp. $886.500,-$ \\
\hline 23 & Romhadi & Rp. 2.337.300,- \\
\hline 24 & Rahayu Katulistiyani & Rp. 1.561.550,- \\
\hline 25 & Ir. Supriyo & $\begin{array}{ll}\text { Rp. } & 886.500,- \\
\end{array}$ \\
\hline 26 & Endah Susilowati Permadi & $\begin{array}{ll}\text { Rp. } & 517.600,-\end{array}$ \\
\hline 27 & Ir. Supriyo & Rp. 4.138.700.- \\
\hline 28 & Ir. Supriyo & Rp. 3.400.000,- \\
\hline 29 & Budiono & Rp. 8.794.600,- \\
\hline 30 & Karsih Tugiyar & Rp. 2.000.000,- \\
\hline 31 & Rasmi Badawi & Rp. 6.000.000,- \\
\hline 32 & Warsih Hadi Susanto & Rp. 2.000.000,- \\
\hline 33 & Mijiasih/M Anwar & Rp. 8.621.800,- \\
\hline 34 & Iba Hariyani & Rp. 5.896.000,- \\
\hline 35 & Sadikin & Rp. 1.200.000,- \\
\hline 36 & Cuti Aryani & Rp. 1.200.000,- \\
\hline 37 & Sundari Pramusinto & Rp. 1.200.000,- \\
\hline 38 & Winarsih Mahmudi & Rp. 1.200.000,- \\
\hline 39 & Suminah Sahid & Rp. 2.864.500,- \\
\hline 40 & Achmad Syakban & Rp. 1.000.000,- \\
\hline 41 & Isman & Rp. 2.750.000,- \\
\hline 42 & Sri Munarsih/Indarto & Rp. 6.000.000,- \\
\hline 43 & Sulasi Masiem & Rp. $875.000,-$ \\
\hline 44 & Eni Sulistiyowati Purwanto & Rp. 1.170.000.- \\
\hline 45 & Soleman & $\begin{array}{ll}\text { Rp. } & 886.500,-\end{array}$ \\
\hline 46 & Muchtar & Rp. 1.630.500,- \\
\hline 47 & Sapari & Rp. $886.500,-$ \\
\hline 48 & Mugini Suyoso & Rp. 4.000.000,- \\
\hline 49 & Suhartoyo & Rp. $\quad 500.000,-$ \\
\hline 50 & Tukimin, Ama Pd & Rp. 2.017.000,- \\
\hline
\end{tabular}

Sumber : Paguyuban Perkampungan Rumah Susun 
Hal ini diharapkan dapat meningkatkan kesejahteraan para penghuni yang sebagian besar adalah karyawan/buruh industri, sehingga mendapatkan keuntungan antara lain :

1. Warga tidak perlu mencari tempat tinggal pengganti dengan lingkungan yang masih sama

2. Dapat menikmati rumah yang layak di perkotaan sesuai dengan peghasilannya.

3. Dapat menikmati lingkungan yang dilengkapi dengan taman,;tempat bermain anak, lapangan olah raga, balai serbaguna yang dipergunakan bersama,

4. Dapat mengembangkan usaha karena di lantai dasar disiapkan untuk tempat usaha

5. Hemat biaya transportasi, dekat dengan tempat kerja.

6. Hemat waktu di perjalanan sehingga dapat meningkatkan produktivitas.

7. Dapat hidup sehat karena tiap rumah dilengkapi dengan $\mathrm{KM} / \mathrm{WC}$, dapur dan tempat jemuran sendiri walaupun type 27.

Hal ini sejalan dengan program Pemda dalam Peremajaan Pemukiman di perkotaan serta Memasyarakatkan Rumah Susun dalam Pemilihan Pemukiman di perkotaan.

Peletakan batu pertama pada tanggal 19-9-1991 oleh Walikota Bapak Soetrisno Suharto dan Peresmian Penghuniannya diresmikan oleh Bapak Presiden Rl Soeharto pada tanggal 24 Oktober 1992.

Sampai saat ini belum ada Peraturan daerah mengenai Rumah Susun di Kota Semarang, oleh karenanya dasar hukum Pelaksanaan Pembangunan Rusun Pekunden antara lain adalah PP NO. 5/1990 tentang Peremajaan Permukinan Kumuh ditengah perkotaan, terutama tanah milik negara.

Gambaran pembangunan rumah susun Pekunden antara lain :

1. Lokasi Rusun Pekunden adalah wilayah Rt 04 dan Rt 05/Rw I Kelurahan Pekunden Kecamatan Semarang Timur (sebelum ada penataan kota);

2. Terdiri dari: 29 bangunan rumah penduduk dan 1 bangunan Musholla Al Mukhsin, yang ditempati oleh $74 \mathrm{KK}$;

3. Survey bulan april 1991 oleh mahasiswa UNDIP yang didampingi oleh Ir.Panggardjito dari PU Cipta Karya Semarang;

4. Penyuluhan warga oleh ketua BAPPEDA Semarang;

5. Usulan warga kepada Tim Satgas Rusun Pekunden :

- Pelaksanaan pembangunan Rusun secara manusiawi/melalui pendekatan;

- Mernbangun tanpa menggusur artinya warga mendapat prioritas utama untuk menghuni rusun;

- Bangunan tidak membuat suasana kumuh baru ada kamar mandi/wc tiap rumah, tempat jemuran dan fasilitas umum yang memadai;

- Sistem tidak merugikan warga masyarakat penghuni;

- Harga sewa rusun terjangkau sesuai kemampuan;

- Selama pembangunan warga tidak diterlantarkan dan diberi biaya pondokan;

- Sarusun yang sudah lunas dapat sertifikat sarusun. 
6. .Kesepakatan warga penghuni dengan Pem. Kodya Semarang tanggal 21-8-1991 :

a) Sebelum rumah dibongkar warga mendapatkan kompensasi sesuai dengan aset yang dimiliki, tetapi untuk membayar uang muka rusun yang akan ditempati;

b) Sebelum membongkar rumah, warga mendapat uang kontrak setahun dan biaya bongkar rumah .

c) Pembagian sarusun diserahkan kepada warga melalui wakil yang ditunjuk (Ny. Suatni).

d) Lantai I untuk usaha, lantai II dan III untuk pemilik rumah lama dan lantai IV untuk pengikut / penyewa / pendatang

e) Harga sarusun tiap Unit Rp 6.000.000,- ( enam juta rupiah) Type $27\left(7,5 \times 3,5 \mathrm{~m}^{2}=\right.$ $27 \mathrm{~m}^{2}$ ) karena mendapat subsidi yang harga aslinya tiap unit Rp 9.000.000,- (pada tanun 1992)

- untuk type 54 harga Rp 12.000.000,-

- untuk type 81 harga Rp 18.000.000,-

8. Peletakan batu pertama pembangunan Rusun Pekunden tanggal 19-9-1991 oleh Walikota Soetrisno Suharto dengan penyerahan uang pondokan secara simbolis kepada 3 wakil warga ( Ny.Suatni, Ny.Wagiyem dan Bp.Ashari) .

9. Tanggal 23-3-1992 wakil warga mendapat panggilan untuk menerima penjelasan dari Asisten I Pemda Bp.Drs.Mugiyono. Bahwa rusun.Pekunden dibangun 5 Blok A,B,C,D.E terdiri dari 108 Unit yang dibuat menjadi 88 ruman rneliputi :

- Type $24 \quad=73$ unit sarusun

- Type $54=10$ unit sarusun

- Type $81=5$ unit sarusun

Jumlah $\quad=88$ unit sarusun

10. Tanggal 77-9-1992, pembagian kunci rusun oleh Ny.Suatni;

Tanggal 18-10-1992, Pembentukan PKK dan Pengurus RT;

- Lantai II wilayah RT 04 dengan Ketua RT Bapak Samija;

- Lantai III wilayah RT 05 dengan Ketua RT Bp. Hadi Susanto;

- Lantai IV wilayah RT 06 dengan Ketua RT Bapak Totok Pruwito.

11. Tanggal 19-140-1992, Tatap muka dengan ketua TP.PKK Kodya Semarang Ibu Soetrisno Suharto di Aula Rusun Pekunden, rnalamnya Briefing oleh Pemda, menyiapkan acara Peresmian Rusun Pekunden oleh Presiden Soeharto, menunjuk 4 wakil untuk wawancara langsung dengan Presiden pada tanggal 24-10-1992. Penjelasan mengenai cicilan rumah tipe 27 tiap bulan Rp.40.000,- / bila harian Rp.1.350,- harga per unit tipe $27=$ Rp. 6.000.000,-

12. Tanggal 24-10-1992 Peresmian Rusun Pekunden. oleh Presiden soeharto di PT Bitratex bersamaan dengan peresmian PIKSA, RSS KORPRI dan Listrik masuk Desa dilanjutkan dengan wawancara langsung dengan presiden, Rusun. diwakili oleh Ny. Suatni Soekisman

13. Tanggal 27-10-1992 membentuk pengurus Paguyuban atas prakarsa Bapak M. Soekisman AW, BA

- Nama : Paguyuban Perkampungan Rumah Susun Pekunden disingkat PPRSP

- Pulindung : - Walikota Sernarang - Soetrisno Suharto

- Camat Semarang Timur - Drs Surono 
- Lurah Pekunden Heru - Mujiran

- Pembina : - Ketua LKMD Pekunden : Prof. Drs. Ardanto

- Tokoh masyarakat : M. Soekisman AW,BA

- Penasehat : Ketua RW I Pekunden : SD. Soebroto

- Program : 5 K Yaitu : Keamanan, Ketertiban, Kebersihan, Keindahan, Kerukunan yang dijadikan pedoman Tata tertib Penghuni Rusun Pekunden sampai sekarang.

- Ketua : Ny. Suatni Soekisman

Masa kerja pengurus \pm 3 tahun kemudian dibentuk baru :

Periode I : tahun $1992-1995$

Periode II : tahun 1995 - 1998

Periode III : tahun 1998 - 2001

Periode IV : tahun 2001 - 2004

Periode V : tahun $2004-2008$

14. Tempat Usaha di Blok A dan E dibangun tahun 1995 dan Pasar Krempyeng dibangun tahun 1997. Kios di blok A dan F sistem sewa ke Pemkot, Pasar Krempyeng dikelola oleh Paguyuban.

\section{Kondisi Rusun Pekunden :}

- Wilayah

- Kelurahan

- Kecamatan

- Kota

- Luas Lahan

- Luas Bangunan

- Jumlah Blok

- Jumlah Lantai

- Jumlah Unit

- Jumlah Kios

- Jumlah Pujasera

- Jumlah Tempat Dasaran : 16 grobog kayu (Lantai Dasar Block C) : 16 meja keramik

- Jumlah Kios Besar : 4 ( Lantai Dasar Block B)

- Jumiah Pompa Artetis : 4

- Jumlah Pompa block : 1

\section{Status Penghuni Rusun Pekunden :}

- 50 rumah status hak milik, sudah bayar uang muka melalui uang kompensasi nilai aset yang dimiliki semula;

- 38 rumah status sewa yang besarnya Rp. 13.500,- s/d Rp.15.000,- setiap bulan langsung ke Pemkot.

- Proses Sertifikat dari 50 rumah sampai saat ini belum selesai. 


\section{Pengelolaan Rusun Pekunden :}

Pengelolaan Rusun Pekunden sangat sederhana, karena dikelola langsung oleh penghuni Paguyuban Perkampungan Rumah Susun Pekunden ( PPRSP ).

A. Sumber Dana :

1. luran warga tiap bulan $=88 \times$ Rp. $13.000,-=R p .1 .144 .000$

2. Hasil retribusi pasar krempyeng = Rp. 300.000

3. Hasil pengelolaan wc umum = Rp. 150.000

4. Hasil pengelolaan air PDAM = Rp. 200.000

5. Hasil parkir sepeda motor di aula $=\mathrm{Rp} . \quad 125.000$

6. Hasil iuran Lt dasar = $\underline{\text { Rp. } \quad 146.000}$

B. Biaya Operasional Sebulan :

1. Rekening listrik pompa dan umum = Rp. 800.000

2. Rekening air ledeng PDAM $=$ Rp. 125.000

3. Honor petugas air bersih $=\mathrm{Rp}$. 250.000

4. Honor petugas pasar dan warung air $=\mathrm{Rp} . \quad 100.000$

5. Honor penyapu / pengangkut sampah = Rp. 150.000

6. Honor petugas parkir = Rp. 50.000

7. Bayar sewa $\mathrm{Bl} / 1,2,3$, tiap bulan $=\mathrm{Rp} . \quad 120.000$

8. Konsumsi rapat pengurus = Rp. 25.000

9. Dana perbaikan dan tak terduga $\quad=\underline{\mathrm{Rp}}$. 445.000

Rp. 2.065.000

C. Sumber Dana Lain

1. Aula Rusun Pekunden disewakan untuk warga yang punya kerja/hajat mantu.

2. Menyewakan meja dan kursi yang ada di aula

3. Kios lantai Dasar Block Bl/1,2 dan 3 yang disewakan kepada yang membutuhkan sistem kontrak tahunan.

D. Catatan

1. Pengurus PPRSP yang mengelola Rusun sejak tahun 1992 s/d sekarang belum pernah mendapatkan honor, hanya dianggap pengabdian

2. Uang sewa Rusun dan Kios lantai Dasar di setor langsung ke Pemkot

3. Bila terjadi kerusakan pompa air atau bangunan rusun yang membutuhkan biaya besar, disamping iuran warga Pengurus mencari pinjaman yang pengembaliannya dianggsur bulanan

4. Untuk biaya pengecatan pagar besi pengaman dari lantai II,III,IV serta mengecat tembok yang.terjangkau, biaya dari iuran semua warga.

\section{Upaya yang akan dilaksanakan :}

1. Rencana akan menaikkan iuran warga untuk memberikan Honor kepada Pengurus PPRSP agar cara kerjanya optimal atau cari dana lain. 
Saat ini karena tidak ada honor untuk Pengurus, yang mau aktif hanya $30 \%$ dari Pengurus yang ada, hanya Petugas oprasional yang mendapat honor.

2. Pendataan kembali pemilik dan penyewa karena sudah banyak yang beralih tangan tanpa setahu PPRSP.

3. Penertiban pemakaian tempat usaha yang sudah banyak yang beralih fungsi menjadi tempat tinggal sehingga lingkungan menjadi kumuh kembali .

4. Mendesak Dinas Tata Kota dan Pemukiman untuk secepatnya menyelesaikan proses sertifikat Rjsun agar kepemilikan sarusun menjadi jelas .

5. Proses Sertifikat Rusun Pekunden sejak tahun 2000 sampai sekarang \pm 7 tahun

6. Mengusahakan asuransi untuk kelangsungan Rusun Mengingat usia bangunan

7. Membentuk Apresiasi Pengelola Rumah Susun Indonesia (APERSI) di Semarang

\section{Tahapan Pelaksanaan Pembangunan Rusun Pekunden :}

1. Pra pembangunan rusun :

a. Penyuluhan :

- Penyuluhan tentang rencana pembangunan rusun oleh Ketua Bappeda Kota Semarang kepada warga Pekunden, Sekayu dan Miroto yang termasuk pemukim tanah milik negara yang akan dibangun rusun;

- Penjelasan PP No. 5 tahun 1990 tentang Peremajaan Pemukiman Kumuh untuk daerah perkotaan di atas tanah milik negara;

b. Menghimpun tanggapan masyarakat yang terkena proyek;

- Kesepakatan warga setuju pembangunan rusun apabila system ganti rugi/kompensasi tidak terlalu merugikan warga, dan setelah jadi mendapatkan prioritas pertama untuk menempati;

- selama pembangunan tidak terlantar dan diberi uang untuk pemondokan;

- pembangunan tidak membuat suasana kumuh baru, mempunyai KM/WC sendiri, tempat jemuran dan fasilitas lain;

- pelaksanaan secara manusiawi dan pendekatan;

- fasilitas rusun dilengkapi mushola, aula, taman, tempat bermain dll;penempatan penghuni disesuaikan seperi sebelum dibangun rusun;

- mendapatkan sertipikat hak;

c. Pengukuran tanah dan bangunan rumah dilokasi proyek;

- pengukuran dan penggambaran rumah lama yang akan dibongkar, lengkap dengan ukuran tanah dan bangunan;

d. Sosialisasi dari Bappeda dan Tim Satgas Rusun Kota Semarang tentang penghitungan kompensasi asset tanah dan bangunan lama dan kesepakatan warga;

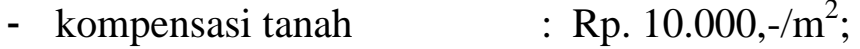

- bangunan permanen : Rp. $75.000,-/ \mathrm{m}^{2}$;

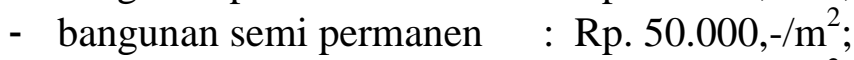

- bangunan non permanen : Rp. 25.000,-// $\mathrm{m}^{2}$;

- biaya kontrak sementara : Rp. 150.000,-/KK;

- biaya pembongkaran rumah : Rp. 50.000,-/pemilik;

- uang kompensasi tidak dibayarkan secara tunai, namun pemilik rumah dianggap sudah bayar uang muka dengan uang kompensasi yang diperolehnya secara 
langsung;

- jumlah kompensasi terkecil Rp. 500.000,- dan terbesar Rp. 17.440.500,-

- sertifikat tidak diperoleh secara langsung/memakan waktu.

e. Penandatanganan gambar rumah/tanah dan surat kesepakatan warga lokasi proyek;

- sebelum dibongkar sudah mendapatkan kompensasi sesuai dengan asset yang dimiliki (luas tanah, bangunan dan fasilitas yang dimiliki);

- sebelum membongkar rumah sudah mendapatkan biaya kontrakminimal satu tahun dan biaya pembongkaran rumah;

- penyewa/pengontrak mendapatkan biaya sendiri;

- tenggang waktu pembongkaran minimal satu bulan.

f. Jadwal pelaksanaan pembongkaran rumah/pindah sementara.

2. Pembangunan rusun :

a. Pemberitahuan gambar bangunan;

- rusun dibangun 5 blok: A, B, C, D, E. terdiri dari 108 unit rusun;

- tempat usaha dibangun di lantai dasar;

- rencana bangunan ukuran standar setiap petak $=7,5 \mathrm{~m} \times 3,5 \mathrm{~m}=27 \mathrm{~m}^{2}$ dilengkapi dengan KM/WC, dengan harga sarusun tiap Unit Rp 6.000.000,(enam juta rupiah) karena mendapat subsidi yang harga aslinya tiap unit Rp 9.000.000,- (pada tanun 1992);

- untuk type 54 harga Rp 12.000.000,-

- untuk type 81 harga Rp 18.000.000,-

- dapat dicicil paling lambat 20 tahun, dengan cicilan Rp. 40.000,-/bulan atau Rp. 1350/hari;

b. Mengajukan usulan pemanfaatan lantai dasar untuk tempat usaha kepada Pimpro dan Pemda oleh wakil warga;

- Penyuluhan tata cara tinggal di rumah susun;

- menjaga kebersihan dan ketertiban;

- mengutamakan kerukunan dan kelompok karena hidup bersama;

- pemakaian KM/WC, membuang sampah, menjemur pakaian dsb;

- perabot lama/rusak tidak dibawa ke rusun;

c. Pembagian rumah kepada warga yang berhak;

- pembagian rumah disesuaikan dengan urutan prioritas;

- untuk pemilik rumah diutamakan di lantai II, kecuali yang type 54, karena di lantai II hanya ada 2, yang lainndi lantai III dilihat dari jumlah uang kompensasi;

- ada beberapa warga yang tukar type, dari 81 ditukar 27 sebanyak 3, type 54 ditukar 27 sebanyak 2, dan type 27 ditukar 81 karena ada sisa dan mampu membayar angsuran;

- warga yang punya tempat usaha akan mendapat prioritas utama;

- pembagian rumah dan pengelolaan diserahkan kepada wkil warga;

- pengontrak diberi kesempatan untuk memiliki dengan angsuran.sewa; 
- warga yang mendapatkan kompensasi mendapatkan unit rusun di lantai II;

- warga pengikut dan pengontrak mendapatkan unit rusun di lantai II dan III;

- sisanya diberikan warga sekitar yang mendesak dan belum punya rumah.

- rusun dibangun 88 unit : type $27=(73)$ unit, type $54=(10)$ unit, type $81=(5)$ unit;

- pembagian tempat telah disepakati :

- pemilik rumah : $81=(4$ warga $), 54=(8$ warga $), 27=(23$ warga $)$;

- pengikut / pengontrak 47 warga;

- sisa 6 unit rumah type $81=(1)$ unit dan type $27=(5)$ unit.

- pengelolaan selama satu tahun di bawah bimbingan PU Cipta Karya;

- lantai dasar akan diatur Pemda untuk usaha yang tidak mengandung resiko;

d. Peresmian rusun;

3. Pembentukaan Paguyuban Perkampungan Rumah Susun :

a. Menetapkan program kerja;

b. Menyusun peraturan tata-tertib penghuni rusun;

c. Menyusun AD/ART; 


\section{Gambar 2. Sketsa Rusun Pekunden tampak dari depan}

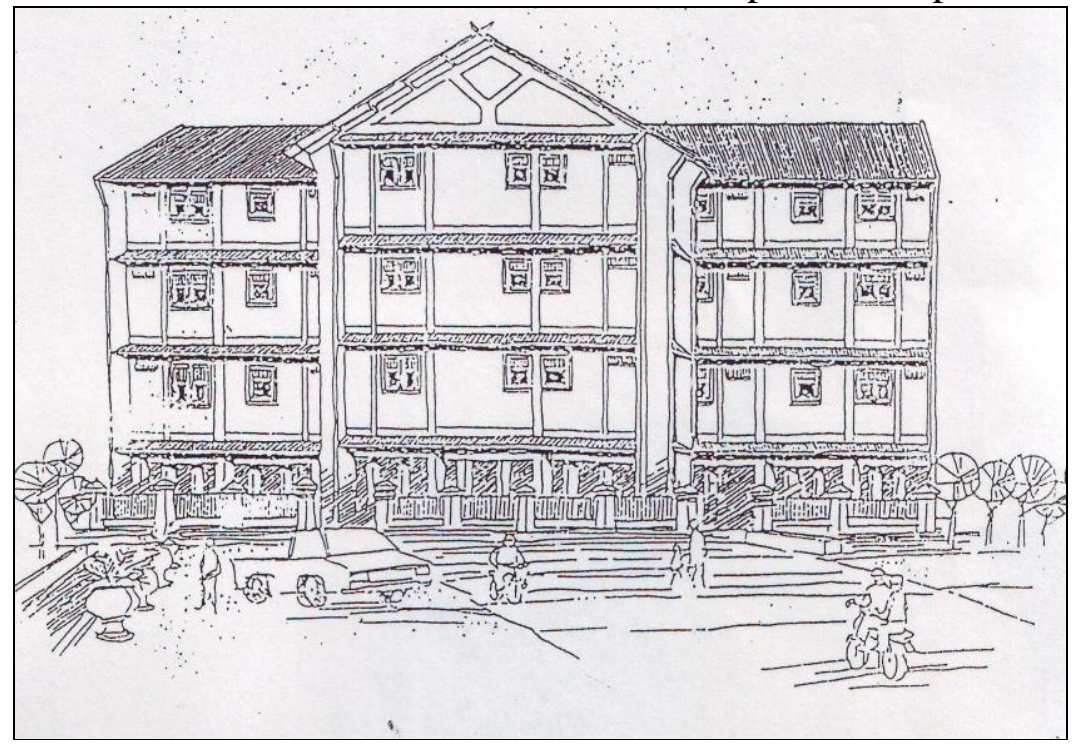

Gambar 3. Sketsa Tapak Rusun Pekunden

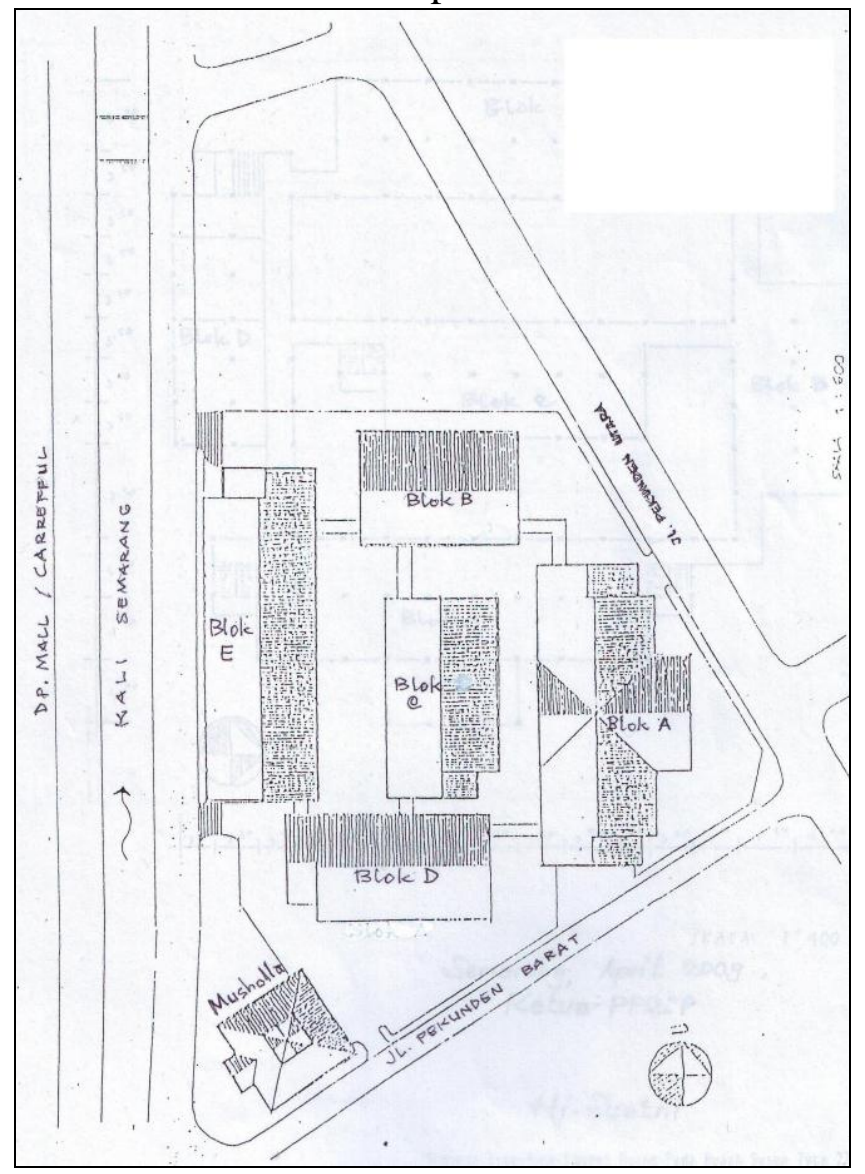




\section{Gambar 4. Fasos \& Fasum Rusun Pekunden}

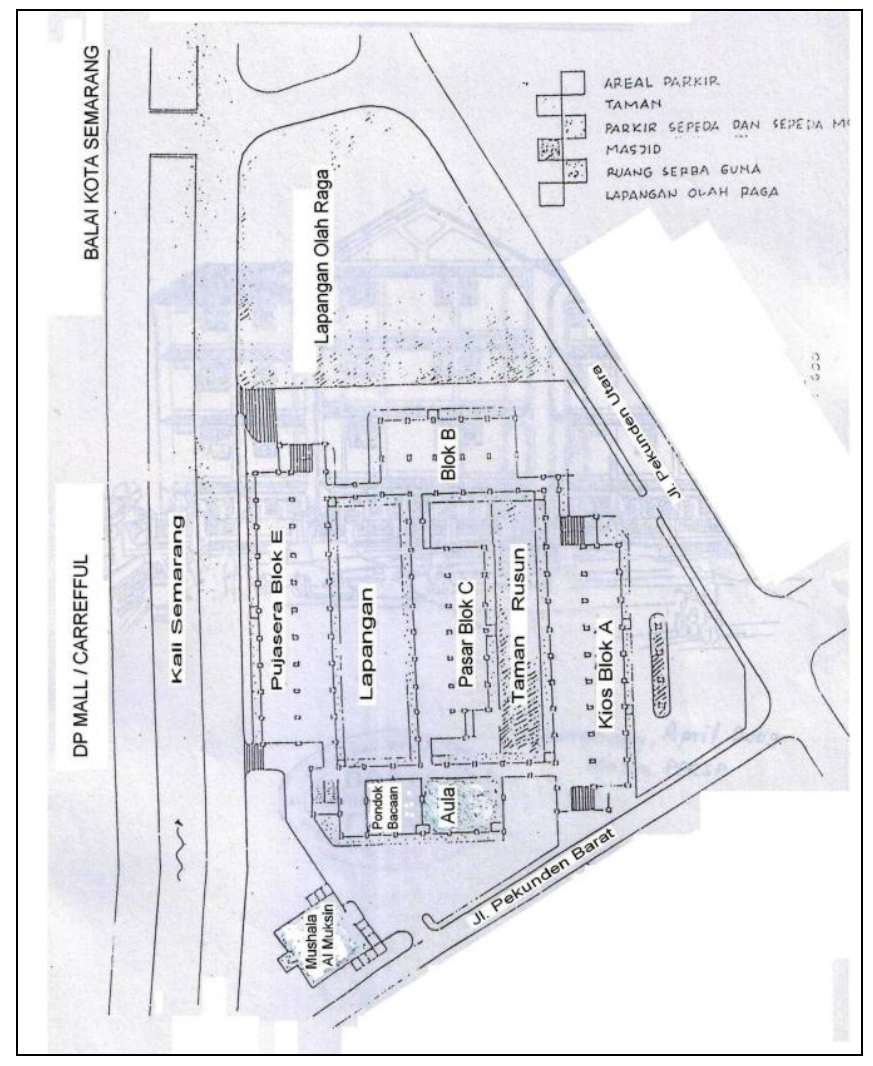

Gambar 5. Denah Lantai Dasar Rusun Pekunden

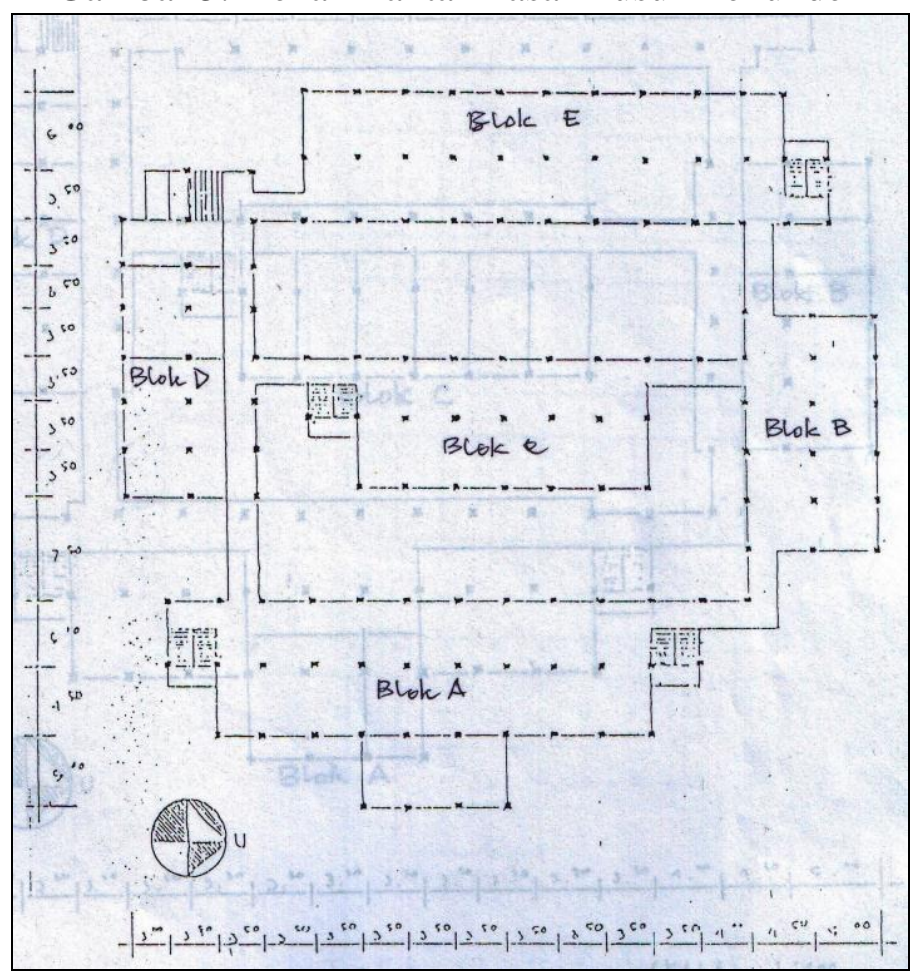


Gambar 6. Denah Lantai 2 Rusun Pekunden

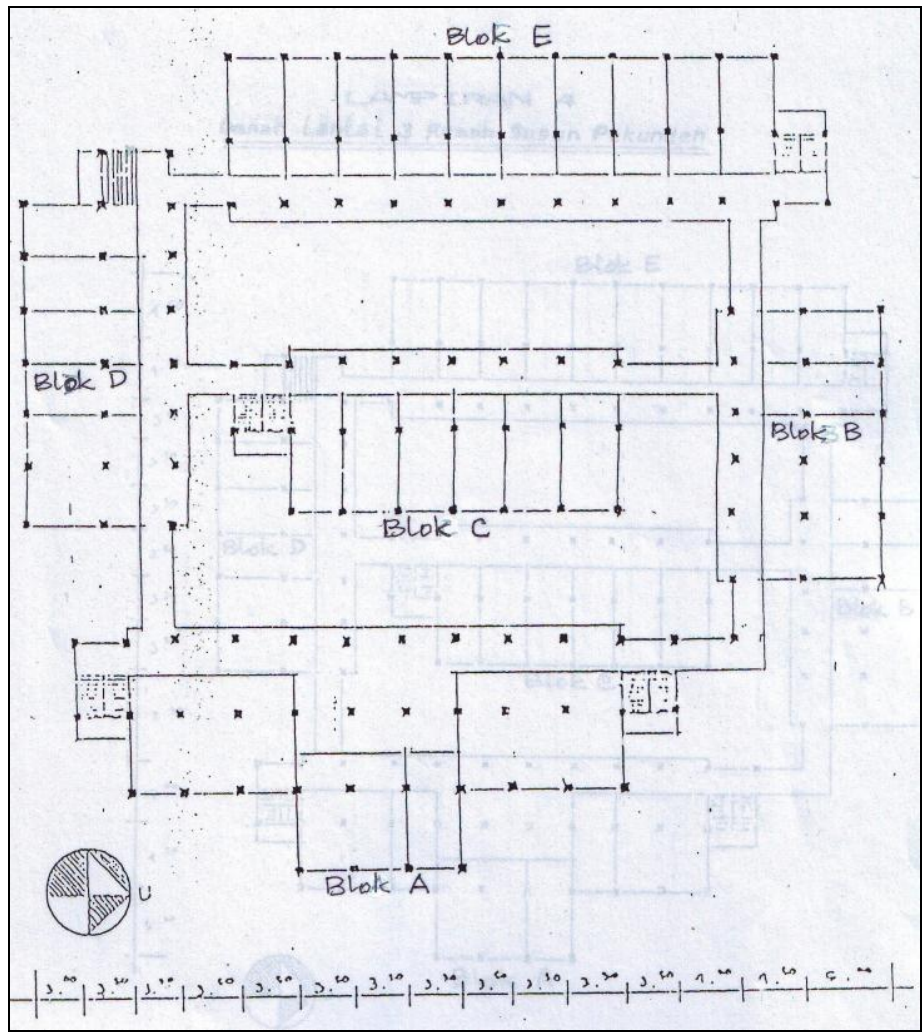

Gambar 7. Denah Lantai 3 \& 4 Rusun Pekunden

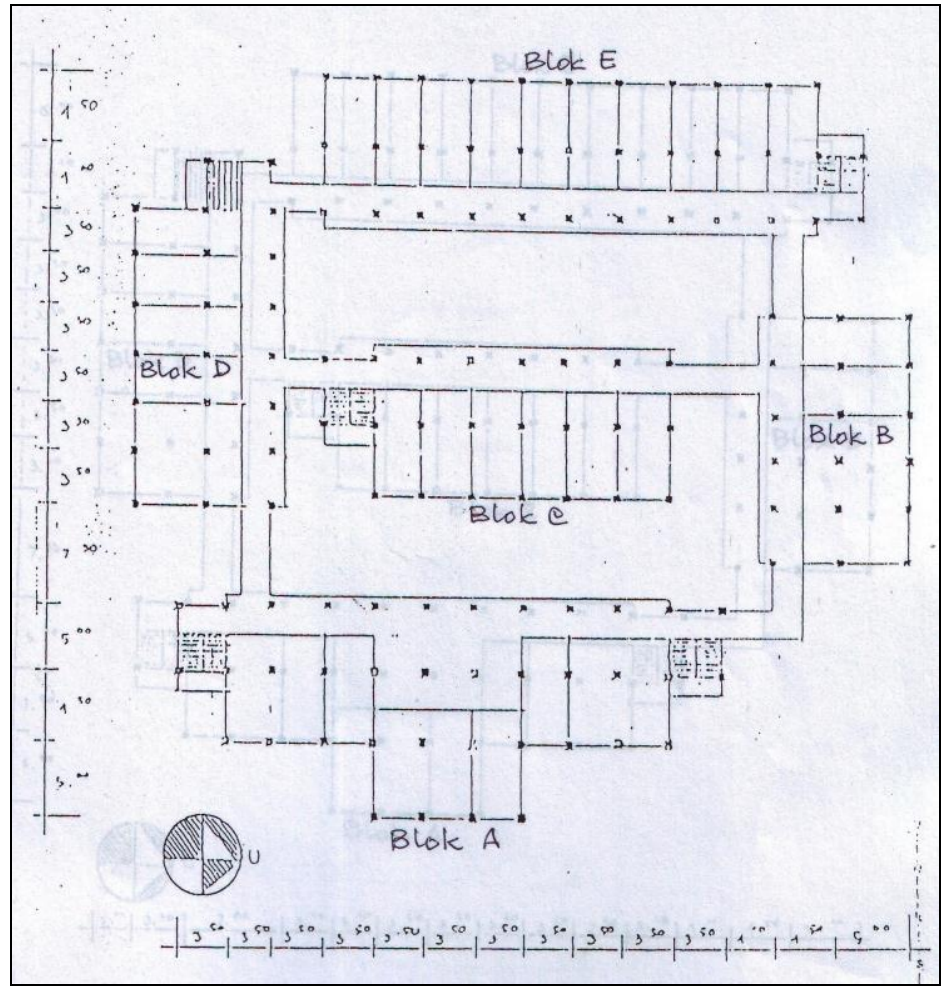


Gambar 8. Rusun Pekunden Type 27

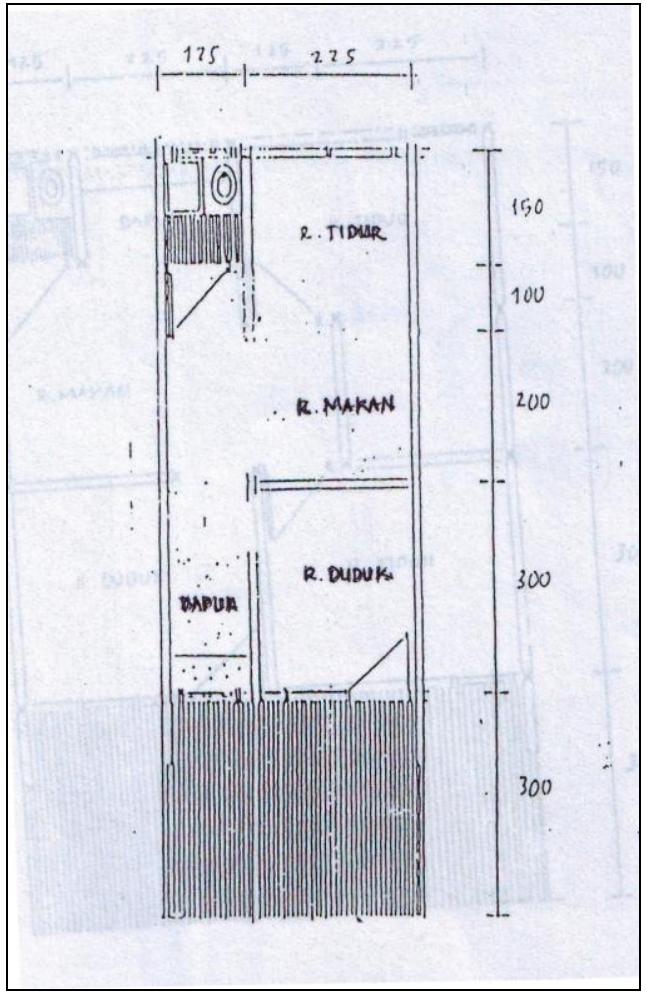

Gambar 9. Rusun Pekunden Type 54

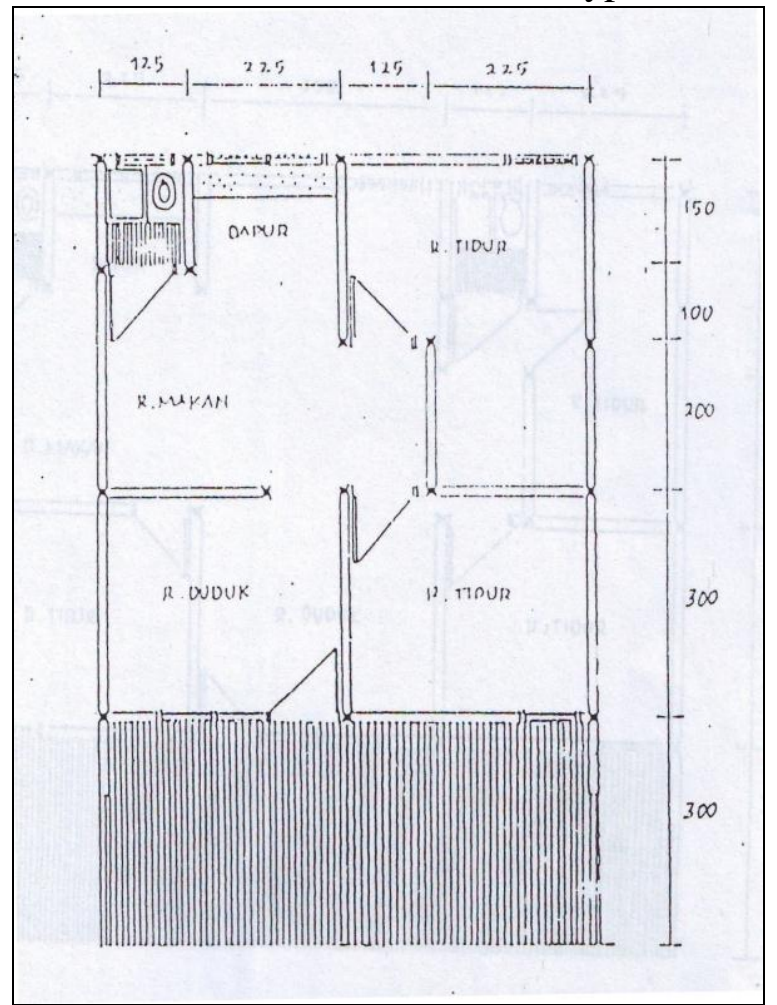




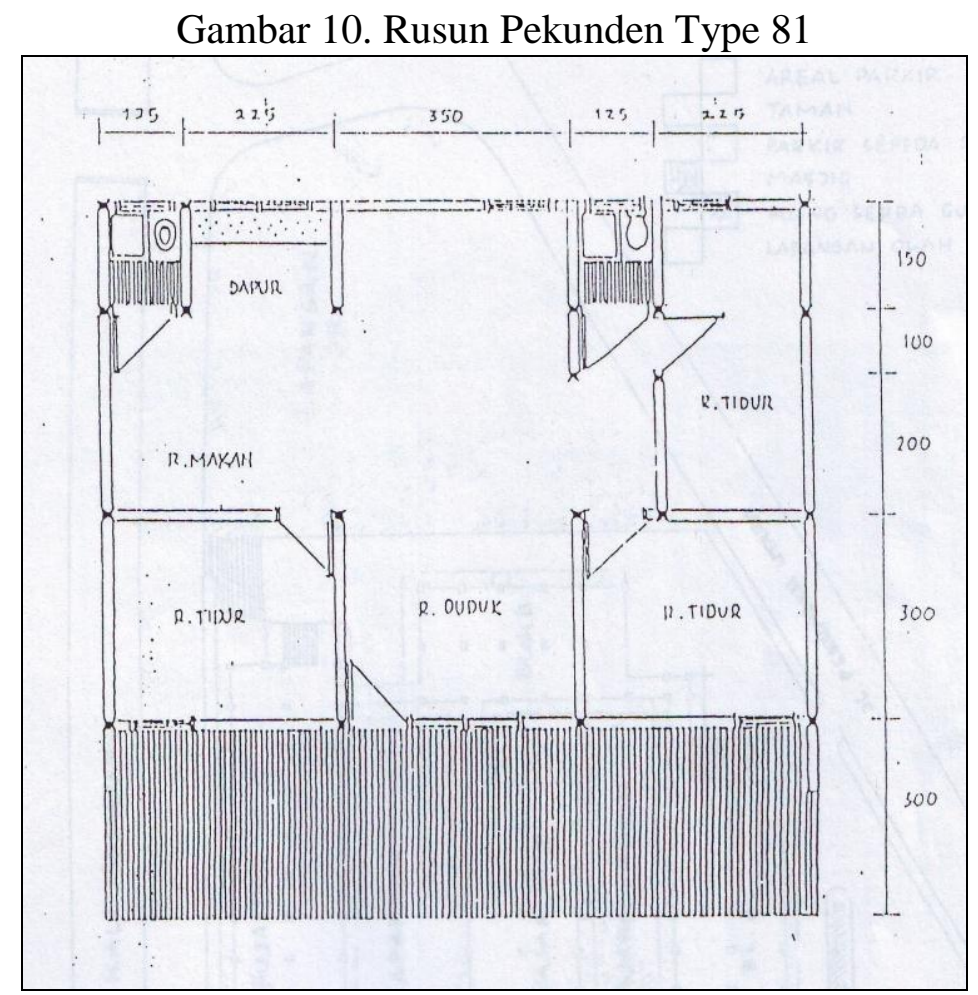

Gambar 11. Rusun Pekunden tampak dari depan

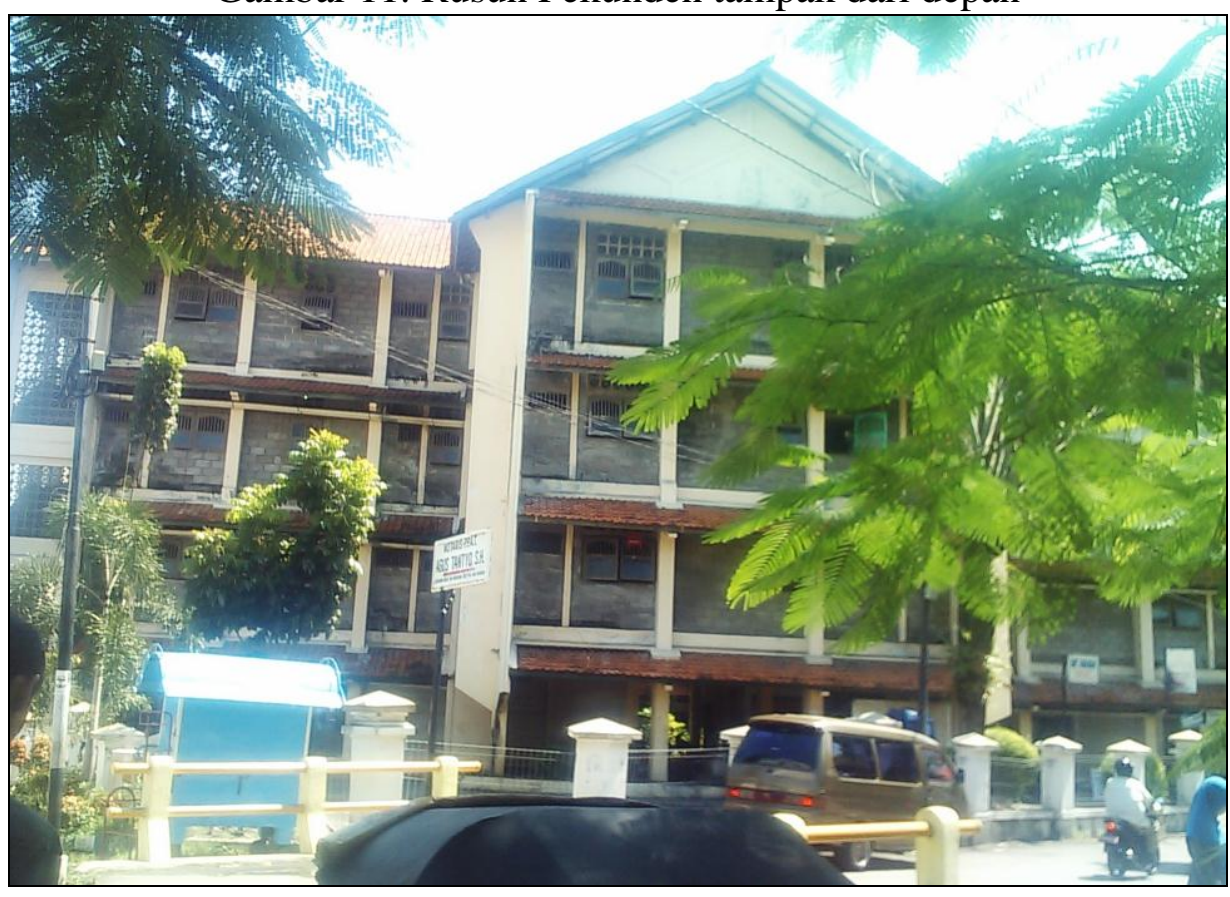

Sampai saat ini dengan waktu yang hampir 19 tahun masyarakat belum mendapatkan sertipikat gratis yang sudah dijanjikan. Menurut Ketua PPRS Pekunden Ibu Hj Suatni Sutarman sedang dalam proses, dalam hal ini ditangani oleh DTKP Kota Semarang, yang menurutnya 
sudah diajukan ke Kantah BPN Kota Semarang, yang di klaim sejak tahun 2006 namun belum dapat menunjukkan bukti adanya permohonan masuk tersebut, dan menurut Kantah BPN Kota Semarang (Kasubsi HTPT) permohonan tersebut pernah diajukan namun hal ini belum dapat diproses dikarenakan adanya kekurangan berkas administrasi yaitu persyaratan adanya Pihak III sebagai Badan Hukum yang mengelola pembangunan rusun tersebut, hal ini belum dapat dipenuhi karena pembangunan rusun tersebut dilaksanakan dan dibiayai oleh Ditjend Ciptakarya Pusat. Menurut pihak DTKP menyatakan (Pemko) sudah menunjuk pihak ke III tersebut yaitu koperasi PDAM selaku pihak ketiga untuk mengelola rusun tersebut, namun sampai saat ini belum pernah mengajaknya berkomunikasi. Hingga saat ini, semua penghuni, baik yang berstatus sewa maupun hak milik rutin membayar PBB. Karena itu, PPRSP hanya mendesak Dinas Tata Kota dan Permukiman (DTKP) karena semua data ada di sana. Ke-50 pemilik rumah telah menuruti permintaan dinas tersebut untuk mengumpulkan fotokopi KK dan KTP dilengkapi materai sampai dua kali.

Menurut Ketua PPRSP sudah berulang kali melayangkan surat ke wali kota dan DTKP, bahkan sampai enam kali pergantian pengurus, tapi tetap tak ada realisasi. Karena tak memiliki sertifikat, mereka mengalami kesulitan untuk menjual rumahnya. Mau tak mau, mereka merelakan rumahnya dihargai rendah karena dijual di bawah tangan.

Dari tabel berikut terlihat bahwa sarusun milik maupun sarusun sewa telah banyak terjadi mutasi pemilikan maupun hunian, menurut sumber dari Ketua PPRSP sudah banyak pemilikan rusun yang dipindahkan pemilikannya melaui jual beli dibawah tangan tanpa ada pengesahan dari pihak manapun, dengan harga berkisar 25 juta s/d 30 juta untuk satu unit rusun type 27. demikian pula untuk rusun sewa telah banyak dialih sewakan dengan jumlah \pm 25 rusun, dengan harga oper sewa sebesar \pm 25 juta dan Pemkot sendiri tidak melarang bahkan dapat diberikan balik nama dengan biaya 250.000. setiap transaksi, dan berdasarkan kesepakatan dikenakan pungutan wajib untuk pengelolaan paguyuban sebesar 2,5\% disetor ke paguyuban. PBB dibayar oleh semua penghuni baik pemilik maupun penyewa.

Rumah susun bukan sekedar rumah-rumah yang disusun begitu saja, tetapi membutuhkan sistem serta sarana yang harus dapat menunjang agar mekanisme orang-orang di dalamnya bisa befungsi baik. Agar sistem dapat berjalan dengan baik maka diperlukan pengaturanpengaturannya antara lain mengenai :

1. Kepemilikan rumah susun, sebagaimana diatur dalam pasal 8 Undang-Undang Nomor 16 Tahun 1985 yang menyatakan bahwa, satuan rumah susun dapat dimiliki oleh perorangan atau badan hukum yang memenuhi syarat sebagai pemegang hak serta hak milik atas satuan rumah susun adalah hak milik yang bersifat perorangan atau terpisah.

2. Jaminan hukum bagi pemilik rumah susun, dalam rangka menjamin kepastian hukum dan kepastian hak bagi pemilik satuan rumah susun, maka diperlukan alat bukti yang kuat, berupa "sertifikat hak milik atas satuan rumah susun" sebagaimana yang diatur dalam Undang-Undang Nomer 16 Tahun 1985 dan Peraturan Pemerintah Nomer 4 Tahun 1988 tentang rumah susun.

3. Mengenai kehidupan para penghuninya diatur dalam Pasal 62 - 70 Peraturan Pemerintah Nomer 4 Tahun 1988 tentang rumah susun yang mengatur bahwa perhimpunan penghuni oleh peraturan perundang-undangan diberi kedudukan sebagai badan hukum yang susunan organisasi, hak, dan kewajibannya diatur dalam Anggaran Dasar dan Anggaran Rumah 
Tangganya, sehingga dapat bertindak keluar dan ke dalam atas nama perhimpunan penghuni dan pemilik dan dengan wewenang yang dimilikinya dapat mewujudkan ketertiban dan ketenteraman dalam lingkungan rumah susun.

4. Perolehan tanah bagi pembangunan rumah susun tersebut. Pada Pasal 7 Undang-Undang Nomer 16 Tahun 1985 menetapkan bahwa rumah susun hanya dapat dibangun di atas tanah yang berstatus hak milik, hak guna bangunan, hak pakai atas tanah negara, dan hak pengelolaan yang diberikan kepada perusahaan pembangunan perumahan yang seluruh modalnya berasal dari pemerintah/pemerintah daerah.

5. Serta mengenai pengaturan-pengaturan yang mengarah pada sistem dan mekanisme rumah susun.

Pemilik rumah susun (50 KK) yang menempati lantai II dan III menurut daftar inventarisasi asset dikenakan pembayaran kekurangan atas nilai unit satuan sarusun yang mereka peroleh sesuai proporsi masing-masing, namun mulai tahun 1992 sampai saat ini belum pernah membayar/dipungut kekurangan tersebut, yang pada awalnya dapat diangsut bulanan. Demikian pula untuk penghuni sewa mereka yang menyewa mulai tahun 1992 sampai tahun 1999 tidak ditarik uang sewa, baru mulai bayar uang sewa tahun 1999. Bahkan kewajiban membayar uang sewa yang sering nunggak tidak diberikan sanksi oleh Pemkot selaku pengelola. Uang sewa semula Rp. 13.500 s/d Rp. 15000 disetor langsung ke Pemda. Untuk tahun 2010 di naikkan menjadi Rp. 40.000 dan Rp. 60.000 per bulan. 
Tabel 12. Penghuni/Pemilik Rusun Pekunden, Kota Semarang

\begin{tabular}{|c|c|c|c|c|}
\hline \multirow[t]{2}{*}{ No. } & \multirow[t]{2}{*}{ Nama } & \multicolumn{2}{|c|}{ Unit Rusun Yang Dihuni } & \multirow[t]{2}{*}{ Pemilik Baru } \\
\hline & & Blok & Type & \\
\hline 1 & Mislah Mardiyanto & $\mathrm{A} / \mathrm{II} / 01$ & 81 & \\
\hline 2 & Amat Salim/lr. Dadik Tafiono & $\mathrm{A} / \mathrm{II} / 02$ & 54 & \\
\hline 3 & Hartono & $\mathrm{A} / \mathrm{II} / 03$ & 27 & Tini Rusmadi \\
\hline 4 & Suatmi, MS & A/II/ 04 & 81 & \\
\hline 5 & M. Ashari & $\mathrm{B} / \mathrm{II} / 05$ & 81 & \\
\hline 6 & Supriyambodo & $\mathrm{B} / \mathrm{II} / 06$ & 27 & \\
\hline 7 & Nunuk Priharti & $\mathrm{B} / \mathrm{II} / 07$ & 27 & Rochmad Hidayat \\
\hline 8 & E. Pujiastuti & $\mathrm{C} / \mathrm{ll} / 08$ & 27 & \\
\hline 9 & Dwi Haryanto & $C / 11 / 09$ & 27 & \\
\hline 10 & Sri Partini & $\mathrm{C} / \mathrm{II} / 10$ & 27 & \\
\hline 11 & Rumiyatun & $\mathrm{C} / \mathrm{II} / 11$ & 27 & \\
\hline 12 & Samija & $\mathrm{C} / \mathrm{II} / 12$ & 27 & \\
\hline 13 & Agus Waluya & $\mathrm{C} / \mathrm{II} / 13$ & 27 & \\
\hline 14 & Munirah & $\mathrm{D} / \mathrm{II} / 14$ & 54 & \\
\hline 15 & Samian Karyono & $\mathrm{D} / \mathrm{II} / 15$ & 27 & \\
\hline 16 & Rakimah & $\mathrm{D} / \mathrm{II} / 16$ & 27 & Lisa Haryono \\
\hline 17 & Sri Wahyuni & $\mathrm{D} / \mathrm{II} / 17$ & 27 & \\
\hline 18 & Sunarno & $\mathrm{D} / \mathrm{II} / 18$ & 27 & Suharti \\
\hline 19 & Suharti Masinem & $E / I I / 19$ & 27 & \\
\hline 20 & Suryahman & $E / I I / 20$ & 27 & \\
\hline 21 & Mardiono & $E / I I / 21$ & 27 & Sri Rahayu \\
\hline 22 & Ponirah & $E / I I / 22$ & 27 & \\
\hline 23 & Romhadi & $E / I I / 23$ & 27 & \\
\hline 24 & Rahayu Katulistiyani & $E / I I / 24$ & 27 & \\
\hline 25 & Ir. Supriyo & $E / I I / 25$ & 27 & Bram Supriyo \\
\hline 26 & Endah Susilowati Permadi & $E / I I / 26$ & 27 & \\
\hline 27 & Ir. Supriyo & $E / / I / 27$ & 27 & \\
\hline 28 & Ir. Supriyo & $E / I I / 28$ & 27 & \\
\hline 29 & Budiono & A / III / 29 & 54 & \\
\hline 30 & Karsih Tugiyar & $\mathrm{A} / \mathrm{III} / 30$ & 27 & \\
\hline 31 & Rasmi Badawi & A / III / 31 & 54 & \\
\hline 32 & Warsih Hadi Susanto & $\mathrm{A} / \mathrm{III} / 32$ & 27 & \\
\hline 33 & Mijiasih/M Anwar & $\mathrm{A} / \mathrm{III} / 34$ & 54 & (dibagi dua) \\
\hline 34 & Iba Hariyani & $\mathrm{B} / \mathrm{III} / 35$ & 81 & \\
\hline 35 & Sadikin & $\mathrm{C} / \mathrm{III} / 40$ & 27 & \\
\hline 36 & Cuti Aryani & $\mathrm{C} / \mathrm{III} / 41$ & 27 & Mahfud Hidayat \\
\hline 37 & Sundari Pramusinto & $\mathrm{C} / \mathrm{III} / 42$ & 27 & \\
\hline 38 & Winarsih Mahmudi & $\mathrm{C} / \mathrm{III} / 43$ & 27 & \\
\hline 39 & Suminah Sahid & $\mathrm{D} / \mathrm{III} / 44$ & 54 & Atik Muhadi \\
\hline 40 & Achmad Syakban & $\mathrm{D} / \mathrm{III} / 45$ & 27 & \\
\hline 41 & Isman & $\mathrm{D} / \mathrm{II} / 46$ & 27 & \\
\hline 42 & Sri Munarsih/Indarto & $E / I I I / 51$ & 27 & \\
\hline 43 & Sulasi Masiem & $\mathrm{E} / \mathrm{III} / 53$ & 27 & Sutadi \\
\hline 44 & Eni Sulistiyowati Purwanto & $\mathrm{E} / \mathrm{III} / 55$ & 27 & \\
\hline 45 & Soleman & $E / I I I / 56$ & 27 & \\
\hline 46 & Muchtar & $\mathrm{E} / \mathrm{III} / 57$ & 27 & Bu Muchtar \\
\hline 47 & Sapari & $\mathrm{E} / \mathrm{III} / 58$ & 27 & \\
\hline 48 & Mugini Suyoso & A/IV / 64 & 54 & \\
\hline 49 & Suhartoyo & $\mathrm{B} / \mathrm{IV} / 66$ & 27 & \\
\hline 50 & Tukimin, Ama Pd & $\mathrm{D} / \mathrm{IV} / 74$ & 54 & \\
\hline
\end{tabular}

Sumber : Paguyuban Perkampungan Rumah Susun 
Tabel 13. Penghuni/Penyewa Rusun Pekunden, Kota Semarang

\begin{tabular}{|c|c|c|c|c|}
\hline \multirow[t]{2}{*}{ No. } & \multirow{2}{*}{ Nama } & \multicolumn{2}{|c|}{ Unit Rusun Yang Dihuni/sewa } & \multirow{2}{*}{$\begin{array}{c}\text { Penghuni/Penyewa } \\
\text { Baru }\end{array}$} \\
\hline & & Blok & Type & \\
\hline 1 & Mochtarom & $\mathrm{A} / \mathrm{III} / 33$ & 27 & \\
\hline 2 & Achmadi & $\mathrm{B} / \mathrm{III} / 36$ & 27 & \\
\hline 3 & Suroyo & $\mathrm{B} / \mathrm{III} / 37$ & 27 & Kris Suwito \\
\hline 4 & Safrudin & $\mathrm{C} / \mathrm{III} / 38$ & 27 & \\
\hline 5 & Waut & $\mathrm{C} / \mathrm{III} / 39$ & 27 & Slamet Suroso \\
\hline 6 & Supardi & $\mathrm{D} / \mathrm{III} / 47$ & 27 & Winda Safri \\
\hline 7 & Slamet Marochan & $\mathrm{D} / \mathrm{III} / 48$ & 27 & \\
\hline 8 & Hadi Susanto & $\mathrm{E} / \mathrm{III} / 49$ & 27 & Wiwin Hadi Susanto \\
\hline 9 & Iwan S & $E / I I I / 50$ & 27 & \\
\hline 10 & Turimin & $\mathrm{E} / \mathrm{III} / 52$ & 27 & \\
\hline 11 & Kasian & $\mathrm{E} / \mathrm{III} / 54$ & 27 & \\
\hline 12 & Tukimin A & $\mathrm{A} / \mathrm{IV} / 59$ & 54 & \\
\hline 13 & Sudiyono A & A / IV / 60 & 27 & Nurimah \\
\hline 14 & Ibnu Supriyanto & $\mathrm{A} / \mathrm{IV} / 61$ & 54 & \\
\hline 15 & Budiman & $\mathrm{A} / \mathrm{IV} / 62$ & 27 & \\
\hline 16 & Kasmi & A / IV / 63 & 27 & \\
\hline 17 & Lianawati & $\mathrm{B} / \mathrm{IV} / 65$ & 81 & Soleman \\
\hline 18 & Abdullah Shodiq & $\mathrm{A} / \mathrm{IV} / 67$ & 27 & \\
\hline 19 & Mulyadi & $\mathrm{C} / \mathrm{IV} / 68$ & 27 & \\
\hline 20 & Samingan & $\mathrm{C} / \mathrm{IV} / 69$ & 27 & \\
\hline 21 & Ninik Saparini & C/IV/ 70 & 27 & Bambang Heri Hartanto \\
\hline 22 & Endi Nugroho & $\mathrm{C} / \mathrm{IV} / 71$ & 27 & Basuki \\
\hline 23 & Sugiyo & $\mathrm{C} / \mathrm{IV} / 72$ & 27 & Baryati \\
\hline 24 & Pramudji & C/IV/ 73 & 27 & Slamet Raharjo \\
\hline 25 & Hasim (M. Khosim) & $\mathrm{D} / \mathrm{IV} / 75$ & 27 & \\
\hline 26 & Zuri Marjan & $\mathrm{D} / \mathrm{IV} / 76$ & 27 & \\
\hline 27 & Masmiah & $\mathrm{D} / \mathrm{IV} / 77$ & 27 & \\
\hline 28 & Juarman & $\mathrm{D} / \mathrm{IV} / 78$ & 27 & \\
\hline 29 & Danu Isnawan & $\mathrm{E} / \mathrm{IV} / 79$ & 27 & \\
\hline 30 & Mochmusri & $\mathrm{E} / \mathrm{IV} / 80$ & 27 & Sudiyanto \\
\hline 31 & Sudiyono E & $\mathrm{E} / \mathrm{IV} / 81$ & 27 & \\
\hline 32 & Anastasia Sarwono & $E / I V / 82$ & 27 & Karyanto \\
\hline 33 & Karsiman & $E / I V / 83$ & 27 & \\
\hline 34 & Ristanto & $\mathrm{E} / \mathrm{IV} / 84$ & 27 & Totok Sutarji \\
\hline 35 & Harsono & $\mathrm{E} / \mathrm{IV} / 85$ & 27 & \\
\hline 36 & Slamet Waluyo & $E / I V / 86$ & 27 & \\
\hline 37 & Eny Suyoko & $\mathrm{E} / \mathrm{IV} / 87$ & 27 & Supoyo \\
\hline 38 & Eko Wiyanto & E / IV / 88 & 27 & Zuhri \\
\hline
\end{tabular}

Sumber : Paguyuban Perkampungan Rumah Susun

\section{b. Kondisi Lingkungan Pemukiman}

Sebagian besar kurang teratur yang merupakan lingkungan padat dengan kualitas bangunan sebagian besar rumah permanen dengan jalan yang sempit, sebagian besar menguasai/memilik tanah kurang atau sama dengan $100 \mathrm{~m}^{2}$. 


\section{Surabaya}

\section{a. Deskripsi Wilayah}

Kota Surabaya terletak antara $112^{\circ} 36^{\prime}-112^{\circ} 54^{\prime}$ Bujur Timur dan antara $07^{\circ} 12^{\prime \prime}-07^{\circ} 21^{\prime \prime}$ Lintang Selatan, dengan luas sekitar $326,36 \mathrm{Km}^{2}$ dari luas wilayah Provinsi Jawa Timur. Kota Surabaya merupakan kota terbesar kedua di Indonesia setelah Jakarta. Wilayahnya merupakan dataran rendah dengan ketinggian 3 - $6 \mathrm{~m}$ di atas permukaan laut, kecuali di sebelah selatan dengan ketinggian $26-50 \mathrm{~m}$ di atas permukaan laut.

Secara administratif Kota Surabaya terdiri dari 14 kecamatan dan 45 kelurahan dengan batas wilayah :

$$
\begin{array}{ll}
\text { - Sebelah Utara } & \text { : Selat Madura } \\
\text { - Sebelah Timur } & \text { : Selat Madura } \\
\text { - Sebelah Selatan } & \text { : Kabupaten Sidoarjo } \\
\text { - Sebelah Barat } & \text { : Kabupaten Gresik }
\end{array}
$$

Topografi Kota Surabaya meliputi :

- Kota Pantai

- Dataran rendah antara 3-6 $\mathrm{m}$ di atas permukaan laut

- Daerah berbukit, di Surabaya bagian selatan 20-30 m di atas permukaan laut

- Temperatur Kota Surabaya cukup panas, yaitu rata-rata antara 22,60 - 34,10, dengan tekanan udara rata-rata antara 1005,2 - 1013,9 milibar dan kelembaban antara $42 \%-97 \%$.

- Kecepatan angin rata-rata perjam mencapai 12 - $23 \mathrm{~km}$, curah hujan rata-rata antara $120-190 \mathrm{~mm}$.

- Jenis Tanah yang terdapat di Wilayah Kota Surabaya terdiri atas Jenis Tanah Alluvial dan Grumosol, pada jenis tanah Alluvial terdiri atas 3 karakteristik yaitu Alluvial Hidromorf, Alluvial Kelabu Tua dan Alluvial Kelabu.

\section{b. Kepadatan Penduduk}

Wilayah Kota Surabaya dibagi dalam 31 kecamatan dan 163 kelurahan. Berdasarkan data BPS tahun 2010, jumlah penduduk mencapai 2.765.908 jiwa. Komposisi penduduk berdasarkan jenis kelamin adalah 49,55 persen laki-laki dan 50,45 persen perempuan. Dengan luas wilayah $326 \mathrm{~km}^{2}$, maka kepadatan penduduk di Surabaya rata-rata adalah 8.475 jiwa per km² . 
Tabel 14. Kepadatan Penduduk Kota Surabaya

\begin{tabular}{|c|c|c|c|c|c|c|}
\hline No. & Kecamatan & $\begin{array}{c}\text { Luas } \\
\text { Wilayah }\end{array}$ & Laki-Laki & Perempuan & Jumlah & $\begin{array}{l}\text { Kepadatan } \\
\text { Penduduk }\end{array}$ \\
\hline 1. & Genteng & 4,04 & 25,999 & 28,506 & 54,505 & 13,491 \\
\hline 2. & Bubutan & 3,86 & 43,333 & 44,550 & 87,883 & 22.767 \\
\hline 3. & Tegalsari & 4,29 & 45,806 & 47,659 & 93,465 & 21,786 \\
\hline 4. & Simokerto & 2,59 & 41,540 & 42,840 & 84,380 & 32,579 \\
\hline 5. & Tambaksari & 8,99 & 92,991 & 95,895 & 188,886 & 21,070 \\
\hline 6. & Gubeng & 7,99 & 63,923 & 69,923 & 132,986 & 16,644 \\
\hline 7. & Krembangan & 8,34 & 57,532 & 56,974 & 114,506 & 13,729 \\
\hline 8. & Semampir & 8,76 & 78,111 & 76,344 & 154,455 & 17,631 \\
\hline 9. & Pabean Cantian & 6,8 & 36,168 & 36,576 & 72,744 & 10,697 \\
\hline 10. & Wonokromo & 8,47 & 72,224 & 74,651 & 146,875 & 17,340 \\
\hline 11. & Sawahan & 6,93 & 92,461 & 96,305 & 188,766 & 27,238 \\
\hline 12. & Tandes & 11,07 & 46,733 & 46,726 & 93,459 & 84,425 \\
\hline 13. & Karang Pilang & 9,23 & 36,727 & 34,751 & 71,478 & 77,440 \\
\hline 14. & Wonocolo & 6,78 & 40,478 & 41,182 & 81,660 & 12,044 \\
\hline 15. & Rungkut & 21,08 & 54,353 & 56,933 & 111,286 & 52,792 \\
\hline 16. & Sukolilo & 223,69 & 51,112 & 49,036 & 100,148 & 44,770 \\
\hline 17. & Kenjeran & 14,42 & 66,697 & 65,160 & 131,857 & 91,440 \\
\hline 18. & Benowo & 45,79 & 33,811 & 33,263 & 67,074 & 14,648 \\
\hline 19. & Lakarsantri & 36,48 & 39,652 & 38,682 & 78,334 & 21,473 \\
\hline 20. & Mulyorejo & 14,21 & 41,134 & 44,158 & 85,292 & 60,002 \\
\hline 21. & Tenggilis Menjoyo & 5,52 & 37,153 & 39,001 & 76,154 & 13,796 \\
\hline 22. & Gunung Anyar & 9,71 & 24,960 & 26,095 & 51,055 & 52,579 \\
\hline 23. & Jambangan & 4,19 & 19,941 & 19,293 & 39,234 & 93,637 \\
\hline 24. & Gayungan & 6,07 & 19,643 & 20,194 & 39,837 & 65,629 \\
\hline 25. & Wiyung & 12,46 & 25,334 & 26,446 & 51,780 & 41,556 \\
\hline 26. & Dukuh Pakis & 9,94 & 28,861 & 28,385 & 57,246 & 57,591 \\
\hline 27. & Asem Rowo & 15,44 & 18,909 & 18,028 & 36,937 & 23,922 \\
\hline 28. & Suko Manunggal & 9,23 & 52,532 & 54,982 & 107,514 & 11,648 \\
\hline 29. & Bulak & - & - & - & - & - \\
\hline 30. & Pakal & - & - & - & - & - \\
\hline \multirow[t]{2}{*}{31.} & Sambi Kerep & - & - & - & - & - \\
\hline & & 326,37 & 1.288 .118 & 1.311 .678 & 2.599 .796 & 79,657 \\
\hline
\end{tabular}

Sumber : Kantor Pertanahan Kota Surabaya

Daerah terpadat di kota Surabaya II ada di tiga kecamatan, yaitu :
a) Tegal Sari
b) Genteng
c) Bubutan

\section{c. Status Tanah}

Status tanah yang ada di Surabaya, antara lain :
a) Hak Milik (bekas agrarisch eigendom)
b) Hak Guna Bangunan
c) Hak Pakai yang diberikan kepada perorangan dan Instansi pemerintah selama diperlukan 
d) Hak Pengelolaan

adalah tanah yang disewakan oleh Pemkot (Pemerintah Kota) Surabaya kepada warga kota tertentu. Sebagai bukti HPL, warga yang menyewa tanah HPL itu diberi surat keterangan yang bersampul hijau. Nah, untuk gampangnya, masyarakat memberi nama kepada tanah HPL itu sebagai tanah "sertifikat hijau” atau surat ijo.

Di atas lahan yang bersertifikat hijau itu, awalnya pada zaman Belanda umumnya dibangun rumah-rumah untuk karyawan. Namun, berdasarkan peta tanah yang ada, apabila tanah itu pemiliknya tidak jelas, maka serta merta Pemkot Surabaya melalui Dinas Tanah menyatakan tanah itu adalah tanah HPL. Tanah HPL ini terpencar di berbagai kelurahan, umumnya di tengah kota yang dulu bukan desa. Tetapi, sekarang tanah bekas tanah ganjaran juga diberlakukan seperti tanah HPL dan dikuatkan dengan "surat ijo".

Nantinya, ada kemungkinan para pemegang HPL yang sekarang didasarkan kepada Perda (Peraturan Daerah) Kota Surabaya, akan memperoleh prioritas perubahan status menjadi HGB. Hal ini sebagai akibat dan desakan masyarakat pemegang tanah HPL yang statusnya masih mengambang. Pemkot Surabaya sendiri masih menunggu bagaimana kebijakan dan keputusan yang diambil oleh DPRD Kota Surabaya sebagai pemutus akhir dalam pembuatan Perda tersebut.

Selain tanah surat Ijo, di Surabaya, ada pula tanah yang disebut dengan "tanah ganjaran". Tanah ganjaran yang merupakan bekas tanah kas desa, sewaktu 103 desa digabung dengan 60 kelurahan di Surabaya, dikelola oleh Bagian Pemerintahan. Sedangkan tahan HPL dikelola Dinas Pengelolaan Tanah dan Rumah. Ada pula tanah sempadan yang dikelola Dinas Binamarga dan Pematusan serta tanah jalur hijau dikelola Dinas Kebersihan dan Pertamanan.

Aset Pemkot Surabaya yang disebut HPL ini berasal dari tanah yang dikuasai Gemeente Surabaya di masa Belanda. Aset Pemkot yang disebut tanah HPL ini cukup luas luasnya, mencapai 13.425.015 meter-persegi atau 134,25 hektar.

Awal tahun 2009, luas tanah surat ijo yang menjadi aset Pemkot Surabaya sudah 146,45 hektar atau 14.645.114,08 meter-persegi. Ada enam jenis status tanah yan pengelolaannya ditangani Badan Pengelolaan Tanah dan Bangunan (BPTB) yang sebelumnya bernama Dinas Pengelolaan Tanah dan Rumah, yaitu ${ }^{7}$ :

- Tanah HPL (Hak Pengelolaan Lahan) 7.686.687 meter per-segi.

- Tanah Hak Pakai seluas 808.427 meter persegi.

- Tanah yang diperoleh dari P2TUN (Panitia Pembelian Tanah Untuk Negara) seluas 622.669 meter persegi.

- Tanah Beslit (pembelian di zaman Belanda) seluas 379.394 meter persegi.

- Tanah Eigendom (milik Pemkot Surabaya) seluas 4.171.732 meter persegi.

- Tanah Negara seluas 976.194 meter persegi.

\footnotetext{
${ }^{7}$ rajaagam. wordpress.com
} 
Tabel 15. Penguasaan dan Pemilikan Tanah di Kota Surabaya

\begin{tabular}{|c|l|l|c|l|}
\hline No. & Penguasaan Tanah & Luas & Bidang & Keterangan \\
\hline 1. & Hak Milik & - & 683.182 & $2002-2006$ \\
\hline 2. & Hak Guna Bangunan & - & 96.811 & \\
\hline 3. & Hak Guna Usaha & - & 49 & \\
\hline 4. & Hak Pengelolaan & - & 514 & \\
\hline 5. & Hak Pakai & - & 8.824 & \\
\hline 6. & HM Sarusun & - & 133 & \\
\hline & Jumlah & - & 744.513 & \\
\hline
\end{tabular}

Sumber : Kanwil BPN Prov. Jawa Timur, 2006

\section{d. Penggunaan Tanah}

Dari segi penggunaan lahan, sampai dengan tahun 2008 kawasan terbangun di Kota Surabaya mencapai 63\% sedangkan sisanya merupakan kawasan tak terbangun meliputi sawah, tegalan, tambak dan tanah kosong (jenis-jenis penggunaan lahan Kota Surabaya dapat dilihat pada Tabel di bawah). Dilihat dari kondisi fisik aspek permukiman, Kota Surabaya masih memiliki permukiman dengan kondisi yang kumuh dan liar (hunian liar). Rumah kumuh merupakan jenis hunian yang menempati tanah legal milik pemerintah dengan kondisi fisik yang dapat dikatakan kurang baik dan dalam tata ruang biasa disebut slum.

Tabel 16. Luas Penggunaan Lahan Per Kecamatan di Kota Surabaya

Tahun 2008

\begin{tabular}{|c|l|r|r|}
\hline No. & \multicolumn{1}{|c|}{ Penggunaan Tanah } & \multicolumn{1}{c|}{ Luas } & \multicolumn{1}{c|}{$\%$} \\
\hline 1. & Perumahan & $13.711,00$ & 42.00 \\
\hline 2. & Sawah & $3.506,19$ & 10.74 \\
\hline 3. & Tegalan & $1.808,90$ & 5.54 \\
\hline 4. & Tambak & $4.982,71$ & 15.26 \\
\hline 5. & Jasa & $2.982,06$ & 9.13 \\
\hline 6. & Perdagangan & 573,32 & 1.75 \\
\hline 7. & Industri/Gudang & $2.370,38$ & 7.26 \\
\hline 8. & Tanah Kosong & $1.784,90$ & 5.46 \\
\hline 9. & Lain-Lain & 918,29 & 2.81 \\
\hline \multicolumn{2}{|c|}{ Jumlah } & $32.637,75$ & 99.95 \\
\hline
\end{tabular}

Keberadaan rumah-rumah kumuh telah menyebar di seluruh kecamatan. Dari hasil pengamatan, maka terlihat bahwa rumah-rumah kumuh di Kota Surabaya paling banyak terdapat di sepanjang pantai dengan mayoritas penduduknya adalah nelayan. Yang paling banyak adalah di wilayah Kenjeran dengan 6 lokasi kumuh, Kecamatan Benowo sebelah utara Surabaya yang juga dipesisir pantai dengan 5 lokasi kumuh. Mengenai hunian liar, sebenarnya hunian liar identik dengan rumah kumuh, hanya saja hunian liar merupakan rumah kumuh yang dibangun diatas tanah yang tidak diperuntukkan untuk bangunan (misalnya daerah bantaran sungai). 
Hunian liar biasanya dibangun dekat dengan tempat usaha/kerja para penghuninya.Lokasi hunian liar di Kota Surabaya diantaranya terdapat di bantaran Sungai Kalimas daerah Benowo dan Rungkut yang didominasi oleh perindustrian. Selain tempat-tempat tersebut, masih ada hunian-hunian liar yang tersebar dalam skala kecil seperti: ditepi rel kereta api, dan tempattempat yang peruntukan lahannya bukan untuk bangunan. Keberadaan hunian liar sangat mengganggu penataan ruang Surabaya. Penyebaran hunian liar terdapat di Kecamatan Benowo (Tambak Oso Wilangun), Gubeng (Ngagel Rejo), Wonokromo (Jagir), Sukolilo (Jangkungan dan Medokan Semampir), Rungkut (Kedung Beruk, Pebjaringansari, Wonorejo dan Kali Rungkut), serta Kecamatan Wonocolo (Sidoresmo).

\section{e. Pelaksanaan Konsolidasi Tanah}

\section{1) Horizontal}

Tabel 17. Lokasi Konsolidasi Tanah Perkotaan di Prop. Jawa Timur (2005 - 2010)

\begin{tabular}{|l|l|c|r|r|c|}
\hline No & \multicolumn{1}{|c|}{ Lokasi } & $\begin{array}{c}\text { Tahun } \\
\text { Pelaksanaan }\end{array}$ & $\begin{array}{c}\text { Jumlah } \\
\text { Bidang }\end{array}$ & $\begin{array}{c}\text { Jumlah } \\
\text { Perserta }\end{array}$ & Keterangan \\
\hline 1 & Kab. Sidoarjo & 2005 & 259 & 281 & Swadaya \\
& & 2006 & 105 & 104 & Swadaya \\
& & 2009 & 5 & 5 & swadaya \\
\hline 2 & Banyuwangi & 2005 & 66 & 66 & Swadaya \\
\hline 3 & Jember & 2005 & 22 & 83 & Swadaya \\
& & 2008 & 5 & 5 & Swadaya \\
& & 2007 & 700 & 700 & APBN \\
\hline 4 & Magetan & 2008 & 113 & 113 & Swadaya \\
& & 2009 & 29 & 29 & Swadaya \\
& & 2007 & 100 & 200 & APBN \\
\hline 5 & Blitar & 2007 & 29 & 37 & swadaya \\
\hline 6 & Kota Madiun & 2008 & 33 & 45 & swadaya \\
\hline 7 & Kota Batu & 2008 & 208 & 11 & APBD-Tk II \\
\hline 8. & Kab. Mojokerto & 2009 & 170 & 235 & Swadaya \\
\hline 9. & Kab. Sumenep & 2009 & 65 & 65 & APBN \\
\hline 10. & Kab. Ponorogo & 2009 & 37 & 37 & APBN \\
\hline
\end{tabular}

Sumber : Kanwil BPN Jawa Timur, 2010

Pada umumnya Konsolidasi Tanah Horizontal dilaksanakan pada lokasi yang belum terbangun, demikian halnya di kabupaten Sidoarjo dilakukan terhadap tanah yang belum dibangun. Konsolidasi tanah dilakukan karena tidak boleh dilakukan pemecahan oleh pemilik tanah lebih dari lima bidang sehingga harus menggunakan user.

Hambatan konsolidasi tanah horizontal khusus di jawa Timur,:

a) konsolidasi tanah dalam rangka pemecahan tanah, ada pendapat bahwa Perkaban No. 6 tahun 1998 tidak boleh melebihi lima bidang, sedangkan UU No. 4 tahun 1992 menyatakan bahwa KSB harus dikonsolidasi dulu baru dijual, sehingga hal ini kontradiksi dengan Perkaban Nomor 6 tahun 1998. 
b) Di Sidoarjo, tanah yang dikonsolidasi sudah terbangun ada perumahan, pada waktu mengajukan sertipikat ada kendala dengan Pemda yang menghendaki jalan untuk konsolidasi harus selebar $8 \mathrm{~m}$ sedangkan BPN mensyaratkan cukup $6 \mathrm{~m}$. Demikian juga dengan penyediaan fasos dan fasum untuk konsolidasi tanah Pemda mensyaratkan melalui Perda harus 40 : 60 ( 40 untuk fasos/fasum), sedangkan BPN mensyaratkan $20 \%$.

Sedangkan konsolidasi tanah di Mojokerto (tahun 2010), dilakukan terhadap tanah untuk perumahan dimana sudah ada rumah yang terbangun, sehingga ada rumah yang dipindahkan (rumah bukan permanen). Rencana awal ada 2 rumah yang akan dipindahkan karena ada 3 rumah yang tidak punya akses jalan, akhirnya ada kesepakatan untuk memindahkan rumah, sehingga semua rumah menghadap ke jalan.

Dari tabel tersebut di atas menunjukkan bahwa konsolidasi tanah horizontal belum pernah dilaksanakan di Kota Surabaya, dan sebagian besar konsolidasi tanah horizontal di Provinsi Jawa Timur di laksanakan secara swadaya.

\section{2) Vertikal}

\section{a. Kebijakan}

Sampai saat ini belum pernah dilaksanakan konsolidasi tanah vertikal (KTV) di Kota Surabaya, namun pembangunan rumah susun yang mirip konsep KTV pernah dilakukan yaitu :

a) di Kampung Sumbo, kelurahan Simolawang Kecamatan Simokerto, konseptornya adalah Johan Silaas. Daerah ini semula adalah kandang sapi yang dikelola oleh orang madura dan terdapat rumah pegawai Dinas Kebersihan kesemuanya di atas tanah Pemerintah Kota, karena kumuh akhirnya dibangun rusun dengan prioritas orang-orang yang semula menetap di daerah tersebut. Jika mereka semula rumahnya besar maka mendapatkan unit lebih banyak dari penghuni lainnya, seperti bapak Kabut yang mendapatkan 9 unit rusun. Rusun yang mulai dibangun pada 14 Desember 1989 dan baru ditempati pada Agustus 1994 itu terdiri atas 603 unit dalam sebelas blok, A--K

b) Di daerah Bangun rejo, semula kampung yang tanahnya berstatus tanah Pemkot, karena kumuh akhirnya dibangun rusun dengan prioritas yang bertempat tinggal, yang rumahnya besar mendapatkan unit lebih banyak seperti Ibu Misni yang mendapatkan 4 unit.

Rusun tersebut di atas mendapatkan fasilitas jalan paving, lampu mercury hanya belum ada fasilitas olah raga, dan dibangun sebelum adanya program 1000 tower.

Walaupun belum pernah dilaksanakan Konsolidasi Tanah Vertikal di Kota Surabaya, namun Seksi Pengaturan dan Penataan Pertanahan Kantah Surabaya telah melakukan inventarisasi kondisi fisik wilayah, penguasaan tanah serta aspek sosial lainnya dalam rangka rencana pembangunan rumah susun melalui konsolidasi tanah, yang diarahkan pada lima lokasi di Kota Surabaya, yaitu :

1) Bantaran kali Surabaya

a) Wilayah Kelurahan jagir dan Ngagelrejo, Kecamatan Wonokromo, Kota Surabaya 
b) RTRW Kota Surabaya Perda No. 3 tahun 2007, untuk Ruang Terbuka Hijau (RTH)

c) Penggunaan Tanah : pemukiman padat, kumuh, tidak teratur dan illegal

d) Kemampuan Tanah :

- Jenis tanah : Aluvial kelabu

- Lereng : 0 -2\%

- Kedalaman efektif : lebih dari $90 \mathrm{~cm}$

- Tekstur : halus

- Drainase : tidak pernah tergenang

- Erosi : tidak ada erosi

e) Penguasaan Tanah : Tanah Negara ( Penguasaan Pengairan )

f) Kepadatan Penduduk : 17.341 jiwa $/ \mathrm{km} 2$

g) Pendapatan rata2 /hari : Rp. 35.000,-/hari

h) Jaringan jalan : sempit, tidak beraturan ; jaringan drainase : sempit/tidak beraturan

2) Gembong

a) Wilayah Kelurahan Bongkaran, Kecamatan Pabean Cantikan, Kota Surabaya

b) RTRW Kota Surabaya : untuk perdagangan dan jasa

c) Penggunaan Tanah : Perkampungan Padat

d) Kemampuan Tanah :

- Jenis tanah : Aluvial Kelabu

- Lereng : $0-2 \%$

- Kedalaman efektif : lebih dari $90 \mathrm{~cm}$

- Tekstur : halus

- Drainase : tidak pernah tergenang

- Erosi : tidak ada erosi

e) Penguasaan Tanah : Tanah Hak Milik dan Hak Guna Bangunan

f) Kepadatan Penduduk : 10.698 jiwa $/ \mathrm{km} 2$

g) Pendapatan rata2/hari : Rp. 50.000,-/hari

h) Jaringan Jalan : sempit sudah dipaving ; Jaringan Drainase : sempit.tidak beraturan

3) Gubeng - Kalibutuh

a) Wilayah Kelurahan : Tembok Dukuh, Kecamatan Bubutan

b) RTRW Kota Surabaya : untuk perdagangan dan jasa

c) Penggunaan Tanah : Perkampungan Padat

d) Kemampuan Tanah :

- Jenis tanah : aluvial kelabu 
- Lereng : $0-2 \%$

- Kedalaman efektif : lebih dari $90 \mathrm{~cm}$

- Tekstur : halus

- Drainase : tidak pernah tergenang'

- Erosi : tidak ada erosi

e) Penguasaan Tanah : Tanah Hak Milik dan hak Guna bangunan

f) Kepadatan Penduduk : 22.768 jiwa $/ \mathrm{km} 2$

g) Pendapatan rata2/hari : Rp. 45.000,-/hari

h) Jaringan jalan : sempit dan sudah diaspal, jaringan drainase: sempit/tidak beraturan

4) Sutorejo
a) Wilayah kelurahan Dukuh Sutorejo, kecamatan Mulyorejo, Kota Surabaya
b) RTRW Kota Surabaya : untuk perumahan
c) Penggunaan tanah : Pemukiman padat
d) Kemampuan tanah :

- Jenis tanah : aluvial hidromort

- Lereng : 0 -2 \%

- Kedalaman efektif : lebih dari $90 \mathrm{~cm}$

- Tekstur : halus

- Drainase : tidak pernah tergenang

- Erosi : tidak ada erosi

e) Penguasaan tanah : Tanah hak yasan dan hak Milik

f) Kepadatan Penduduk : 6.002 jiwa $/ \mathrm{km} 2$

g) Pendapatan rata2/hari : Rp. 40.000,-/hari

h) Jaringan jalan : sempit, masih berupa tanah, jaringan drainase : sempit/tidak beraturan

5) Keputih

a) Wilayah kelurahan keputih, Kecamatan Sukolilo, Kota Surabaya.

b) RTRW Kota Surabaya : untuk perumahan

c) Penggunaan Tanah : Pemukiman

d) Kemampuan Tanah :

- Jenis tanah : aluvial hidromort

- Lereng : 0 -2\%

- Kedalaman efektif : lebih dari $90 \mathrm{~cm}$

- Tekstur : halus

- Drainase : tidak [pernah tergenang

- Erosi : tidak ada erosi 
e) Penguasaan tanah : tanah hak yasan dan hak Milik

f) Kepadatan penduduk : 4.227 jiwa/km2

g) Pendapatan rata2/hari : Rp. 40.000,-/hari

h) Jaringan jalan $\mathrm{Z}$ : sempit, masih berupa tanah, jaringan drainase : sempit/tidak beraturan.

\section{b. Kondisi Lingkungan Perumahan}

Merupakan pemukiman padat penduduk dengan jaringan jalan : sempit, tidak beraturan ada yang masih berupa tanah, ada yang sudah di paving dan diaspal; jaringan drainase : sempit/tidak beraturan.

\section{Bandung}

\section{a. Deskripsi Wilayah}

Kota Bandung terletak antara garis $107^{\circ} 40^{\prime} 163^{\prime \prime}$ Bujur Timur dan garis $06^{\circ} 56^{\prime} 32^{\prime \prime}$ Lintang Selatan. Kota Bandung dikelilingi oleh pegunungan, sehingga bentuk morfologi wilayahnya bagaikan sebuah mangkok raksasa, secara geografis kota ini terletak di tengahtengah provinsi Jawa Barat, serta berada pada ketinggian $\pm 768 \mathrm{~m}$ di atas permukaan laut, dengan titik tertinggi di berada di sebelah utara dengan ketinggian 1.050 meter di atas permukaan laut dan sebelah selatan merupakan kawasan rendah dengan ketinggian 675 meter di atas permukaan laut.

Wilayah Kota Bandung sebelah utara berbatasan dengan Kabupaten Bandung, sebelah timur berbatasan dengan Kabupaten Bandung, sebelah barat berbatasan dengan Kabupaten Bandung sedangkan sebelah selatan berbatasan dengan Kabupaten Bandung. Luas wilayah Kota Bandung 167,45 km2 dan terbagi menjadi dua puluh enam kecamatan. Kota Bandung dialiri dua sungai utama, yaitu Sungai Cikapundung dan Sungai Citarum beserta anak-anak sungainya yang pada umumnya mengalir ke arah selatan dan bertemu di Sungai Citarum. Dengan kondisi yang demikian, Bandung selatan sangat rentan terhadap masalah banjir.

Keadaan geologis dan tanah yang ada di kota Bandung dan sekitarnya terbentuk pada zaman kwartier dan mempunyai lapisan tanah alluvial hasil letusan gunung Tangkuban Parahu. Jenis material di bagian utara umumnya merupakan jenis andosol begitu juga pada kawasan dibagian tengah dan barat, sedangkan kawasan dibagian selatan serta timur terdiri atas sebaran jenis alluvial kelabu dengan bahan endapan tanah liat.

\section{b. Kepadatan Penduduk}

Penduduk Kota Bandung menurut Registrasi Penduduk sampai dengan bulan Maret 2009 berjumlah : 2.510 .982 jiwa dengan luas wilayah 16.729,50 Ha. (167,67 Km 2 ), sehingga kepadatan penduduknya per hektar sebesar 155 jiwa. Komposisi penduduk warga negara asing yang berdomisili di Kota Bandung adalah sebesar 4.301 jiwa. Jumlah warga negara asing menurut catatan Kantor Imigrasi Bandung yang berdiam tetap di Kota Bandung setiap bulannya rata-rata sebesar 2.511 orang, sedangkan jumlah warga negara asing yang berdiam sementara di Kota Bandung setiap bulannya rata-rata sebesar 5.849 jiwa. 


\section{c. Status Tanah}

Penguasaan Tanah di Kota Bandung ada beberapa jenis, antara lain :

- Hak Milik

- Hak Guna Bangunan

- Hak Pengelolaan

- Hak Pakai

- Hak Milik atas Satuan Rumah Susun

Tabel 18. Penguasaan dan Pemilikan Tanah di Kota Bandung

\begin{tabular}{|l|l|r|r|l|}
\hline No. & Penguasaan Tanah & Luas & \multicolumn{1}{l|}{ Bidang } & Keterangan \\
\hline 1. & Hak Milik & 102.232 .393 & 410.400 & \\
\hline 2. & Hak Guna Bangunan & 16.213 .085 & 80.774 & \\
\hline 3. & Hak Guna Usaha & - & - & \\
\hline 4. & Hak Pengelolaan & 978.218 & 43 & \\
\hline 5. & Hak Pakai & 9.262 .124 & 2.244 & \\
\hline 6. & Tanah Wakaf & - & - & \\
\hline 7. & Sarusun & 9.017 .218 & 8.374 & \\
\hline & Jumlah & 147.703 .038 & 501.835 & \\
\hline
\end{tabular}

\section{d. Penggunaan Tanah}

Tabel 19. Jenis Penggunaan Tanah di Kota Bandung

\begin{tabular}{|c|l|r|c|}
\hline No. & \multicolumn{1}{|c|}{ Jenis Penggunaan Tanah } & \multicolumn{1}{c|}{ Luas $(\mathrm{Ha})$} & Keterangan \\
\hline 1. & Perumahan & 9479.00 & \\
\hline 2. & Jasa & 1343.00 & \\
\hline 3. & Perusahaan & 172.88 & \\
\hline 4. & Industri & 631.00 & \\
\hline 5. & Pertanian & 3278.56 & \\
\hline 6. & Non produktif/lahan kosong & 540.00 & \\
\hline 7. & Lain-lain & 1285.56 & \\
\hline 8. & Jumlah & 16730.00 & \\
\hline
\end{tabular}

Sumber : Kanwil BPNProv. Jawa Barat

\section{e. Pelaksanaan Konsolidasi tanah}

\section{1) Horizontal}

Pelaksanaan konsolidasi tanah horizontal dilaksanakan di Kota Bandung pertama kalinya pada tahun 1986, di kelurahan Babakan Surabaya, kecamatan Kiara Condong yang juga merupakan contoh ideal dari konsolidasi tanah perkotaan. 
Tabel 20. Lokasi Konsolidasi tanah di Kota Bandung

\begin{tabular}{|l|l|c|r|c|c|}
\hline No & \multicolumn{1}{|c|}{ Lokasi } & $\begin{array}{c}\text { Tahun } \\
\text { Pelaksanaan }\end{array}$ & Luas (Ha) & $\begin{array}{c}\text { Jumlah } \\
\text { Bidang }\end{array}$ & Keterangan \\
\hline 1 & $\begin{array}{l}\text { Babakan Surabaya, } \\
\text { Kiara Condong }\end{array}$ & $1986-1987$ & 7.7068 & 78 & APBN \\
\hline 2 & Cingcin, Katapang & $1986-1987$ & 0,4805 & 25 & - \\
\hline 3 & $\begin{array}{l}\text { Pasanggrahan, Ujung } \\
\text { Berung }\end{array}$ & 2005 & 2.9674 & 51 & swadaya \\
\hline
\end{tabular}

\section{2) Vertikal}

\section{a. Kebijakan}

Bandung menjadi kota terpadat setelah Jakarta, sehingga slum area masih menjadi permasalahan utama di kota Bandung. Jika tingkat pertumbuhan penduduk konstan atau sekitar 1,59\% per tahun,maka penduduk Kota Bandung pada 2013 diperkirakan mencapai 2,6 juta jiwa atau sekitar 5 juta jiwa pada $2015 .^{8}$ Permukiman kumuh terdiri atas beberapa kategori, yakni kategori tinggi terdapat di 29 RW yang meliputi Kecamatan Astanaanyar, Bandung Wetan, Kiaracondong, dan Sumur Bandung, kategori sedang di 88 RW yang meliputi Kecamatan Bojongloa Kidul, Coblong, Cinambo, dan Rancasari. Adapun permukiman kumuh dengan kategori rendah tersebar di 77 RW yang meliputi Kecamatan Rancasari, Lengkong, Ujung Berung,Cibiru,dan Cicendo. Oleh karena itu pembangunan rumah susun direncanakan berada disetiap kecamatan.

Pembangunan rumah susun melalui konsolidasi tanah vertikal belum pernah dilaksanakan di Kota Bandung, yang sudah dilaksanakan adalah pembangunan rusunami dan rusunawa.

Tabel 21. Lokasi rusunawa di Kota Bandung

\begin{tabular}{|c|c|c|c|c|}
\hline No. & Lokasi & Kecamatan & $\begin{array}{l}\text { Ketersediaan } \\
\text { Rumah }\end{array}$ & $\begin{array}{c}\text { Kebutuhan } \\
\text { Rumah (Blok) }\end{array}$ \\
\hline 1. & 2. & 3. & 4. & 5. \\
\hline 1. & Cingised & Cisaranten Kulon & 454 & 5 (twin blok) \\
\hline 2. & Rancacili & Derwati & 70 & 8 (twin blok) \\
\hline 3. & Sadang Serang I & Sadang Serang & - & - \\
\hline 4. & Sadang Serang II & Sadang Serang & 96 & 1 (twin blok) \\
\hline 5. & Kawasan Industri Dalam & Cicendo & 200 & 1 (twin blok) \\
\hline 6. & Kawasan Taman Sari I & Bandung Wetan & 96 & 1 (twin blok) \\
\hline 7. & Kawasan Taman Sari II & Bandung Wetan & 96 & 1 (twin blok) \\
\hline 8. & Kawasan Taman Sari III & Bandung Wetan & 96 & 1 (twin blok) \\
\hline
\end{tabular}

Untuk lokasi rusunami di Kota Bandung terletak di Buah Batu ( kecamatan Gujang Sari dan kecamatan Bandung Kidul) serta rusunami di Sarijadi.

\footnotetext{
${ }^{8} \mathrm{http} / /$ www.apeksi.or.id
} 
Yang sudah pernah mencoba untuk melaksanakan konsolidasi tanah vertikal adalah Kota Cimahi namun terhambat masalah peraturan pelaksanaannya. Dilihat dari segi kepadatan penduduk, terlihat bahwa kepadatannya cukup tinggi yaitu $13.351 \mathrm{jiwa} / \mathrm{km} 2$. Dengan kepadatan penduduk yang demikian tinggi diperlukan upaya penataan pada kawasan padat penduduk, sehingga kemudian dilaksanakan kegiatan konsolidasi tanah di kelurahan cigugur tengah kecamatan cimahi selatan dan kelurahan cibabat, kecamatan cimahi utara.

Konsolidasi Tanah Vertikal direncanakan akan dibangun di RW 18 Kelurahan Cibabat, Kecamatan Cimahi Utara . Adapun luas wilayah RW $18 \pm 65.505$ m2 dan terdiri dari 415 bidang, dengan bidang tanah terkecil seluas $\pm 28 \mathrm{~m} 2$. NJOP terendah di wilayah itu adalah Rp. 40.000,-, dan NJOP tertinggi sebesar Rp. 537.000,-. Mayoritas penggunaan tanahnya adalah rumah dengan pekarangan sebanyak 224 bidang, rumah tanpa pekarangan sebanyak 141 bidang, sawah/kolam sebanyak 65 bidang, tanah kosong sebanyak 39 bidang dan tegalan/kebun sebanyak 6 bidang. Karena tidak adanya peraturan yang mengatur tentang Konsolidasi Tanah Vertikal akhirnya program ini tidak jadi dilaksanakan.

Respon masyarakat ketika peneliti meminta tanggaannya tentang rencana pembangunan rumah susun di tanah mereka pada umumnya menolak, mereka lebih memilih untuk menjual tanahnya dan membeli tanah di tempat lain. Mereka menganggap lebih menguntungkan untuk dijual dari pada dibangun rumah susun, kecuali jika ada kepastian bahwa mereka akan diberdayakan apabila dibangun rumah susun, artinya selain bertempat tinggal di rumah susun mereka juga mendapatkan pekerjaan atau mendapat tambahan penghasilan.

\section{b. Kondisi Lingkungan Pemukiman}

Rumah sangat padat dan ukurannya kecil-kecil, saluran air berukuran kecil dan tidak beraturan, demikian juga jalan walaupun di semen sangat kecil hanya cukup untuk satu orang.

\section{Medan}

\section{a. Deskripsi Wilayah}

Kota Medan memiliki luas 26.510 hektar $\left(265,10 \mathrm{~km}^{2}\right)$ atau 3,6\% dari keseluruhan wilayah Sumatera Utara. Dengan demikian, dibandingkan dengan kota/kabupaten lainya, Medan memiliki luas wilayah yang relatif kecil dengan jumlah penduduk yang relatif besar. Secara geografis kota Medan terletak pada $3^{\circ} 30^{\prime}-3^{\circ} 43^{\prime}$ Lintang Utara dan $98^{\circ} 35^{\prime}-98^{\circ} 44^{\prime}$ Bujur Timur. Untuk itu topografi kota Medan cenderung miring ke utara dan berada pada ketinggian 2,5 - 37,5 meter di atas permukaan laut.

Medan juga merupakan kota terbesar ketiga di Indonesia setelah Jakarta dan Surabaya. Medan merupakan pintu gerbang wilayah Indonesia bagian barat dan juga sebagai pintu gerbang bagi para wisatawan untuk menuju objek wisata Brastagi di daerah dataran tinggi Karo, objek wisata Orangutan di Bukit Lawang, Danau Toba.

Kota ini menjadi pintu bagi arus penumpang dan juga perdagangan barang dan jasa, baik perdagangan domestik maupun luar negeri. Bagi Kota Medan, kegiatan perdagangan bersama aktivitas hotel dan restoran menjadi motor penggerak roda perekonomian kota. Pelabuhan laut 
berperan penting dalam mendorong pertumbuhan perekonomian di suatu wilayah. Pelabuhan laut yang menjadi andalan Kota Medan adalah Pelabuhan Belawan yang berjarak $26 \mathrm{~km}$ dari pusat kota. Pelabuhan ini tidak hanya berperan penting bagi perekonomian Kota Medan, namun juga bagi Provinsi Sumatera Utara. Kegiatan ekspor dan impor Kabupaten/Kota lain dilakukan di pelabuhan ini yang dapat dilihat dari aktivitas bongkar.muat barang setiap harinya.

Medan, kota berpenduduk 2 juta orang memiliki areal seluas 26.510 hektar yang secara administratif dibagi atas 21 kecamatan yang mencakup 151 kelurahan. Sebagai sebuah kota, ia mewadahi berbagai fungsi, yaitu, sebagai pusat administrasi pemerintahan, pusat industri, pusat jasa pelayanan keuangan, pusat komunikasi, pusat akomodasi kepariwisataan, serta berbagai pusat perdagangan regional dan internasional.

\section{b. Kepadatan penduduk}

Berdasarkan data kependudukan tahun 2010, penduduk Medan saat ini diperkirakan telah mencapai 2.109.339 jiwa, dengan jumlah wanita lebih besar dari pria. Jumlah penduduk tersebut diketahui merupakan penduduk tetap, sedangkan penduduk tidak tetap diperkirakan mencapai lebih dari 500.000 jiwa, yang merupakan penduduk komuter. Dengan demikian Medan merupakan salah satu kota dengan jumlah penduduk yang besar.

Tabel 22. Tingkat Kepadatan Penduduk

\begin{tabular}{|l|r|r|r|}
\hline \multicolumn{1}{|c|}{ Kecamatan } & $\begin{array}{c}\text { Jumlah } \\
\text { Penduduk }\end{array}$ & $\begin{array}{c}\text { Luas Wilayah } \\
\left(\mathrm{km}^{2}\right)\end{array}$ & \multicolumn{1}{c|}{ Kepadatan } \\
\hline Medan Tuntungan & 70073 & 20,68 & 3388 \\
Medan Johor & 116220 & 14,58 & 7971 \\
Medan Amplas & 115156 & 11,19 & 10291 \\
Medan Denai & 139939 & 9,05 & 15463 \\
Medan Area & 109253 & 5,52 & 19792 \\
MedanKota & 84292 & 5,27 & 15995 \\
Medan Maimun & 57859 & 2,98 & 19416 \\
Medan Polonia & 53427 & 9,01 & 5930 \\
Medan Baru & 44216 & 5,84 & 7571 \\
Medan Selayang & 85678 & 12,81 & 6688 \\
Medan Sunggal & 110667 & 15,44 & 7168 \\
MedanHelvetia & 145376 & 13,16 & 11047 \\
Medan Petisah & 68120 & 6,82 & 9988 \\
Medan Barat & 79098 & 5,33 & 14840 \\
Medan Timur & 113874 & 14675 \\
Medan Perjuangan & 105702 & 7,76 & 25844 \\
Medan Tembung & 141786 & 4,09 & 17745 \\
Medan Deli & 150076 & 7,99 & 7201 \\
Medan Labuhan & 106922 & 20,84 & 2916 \\
Medan Marelan & 126619 & 36,67 & 5316 \\
Medan Belawan & 96700 & 23,82 & 3684 \\
\hline Medan & 2121053 & 26,25 & 8001 \\
\hline
\end{tabular}


Dari tabel di atas menunjukkan, kepadatan tertinggi berada di kecamatan Medan Perjuangan sebesar 25844 jiwa/km2, kedua adalah kecamatan Medan Area sebesar 19792 jiwa/km2, dan ketiga adalah kecamatan Medan Maimun sebesar 19416 jiwa/km2.

\section{c. Status Tanah}

Penguasaan Tanah di Kota Medan ada beberapa jenis, antara lain :

- Hak Milik

(ada yang berdasarkan konversi dari tanah grant sultan)

- Hak Guna Bangunan

- Hak Guna Usaha

- Hak Pengelolaan

- Hak Pakai yang diberikan kepada perorangan dan Instansi pemerintah selama diperlukan

- Tanah Wakaf

Tabel 23. Penguasaan dan Pemilikan Tanah di Kota Medan

\begin{tabular}{|l|l|l|l|l|}
\hline No. & Penguasaan Tanah & Luas & Bidang & Keterangan \\
\hline 1. & Hak Milik & - & 538.192 & \\
\hline 2. & Hak Guna Bangunan & - & 139.672 & \\
\hline 3. & Hak Guna Usaha & - & 566 & \\
\hline 4. & Hak Pengelolaan & - & 161 & \\
\hline 5. & Hak Pakai & - & 46.329 & \\
\hline 6. & Tanah Wakaf & - & 902 & \\
\hline 7. & Sarusun & - & 410 & \\
\hline & Jumlah & - & 726.187 & \\
\hline
\end{tabular}

\section{d. Penggunaan Tanah}

Topografi Kota Medan cenderung miring ke Utara dan berada pada ketinggian 2,5 -37,5 meter diatas permukaan laut.

Dari luas wilayah Kota Medan dapat dipersentasekan sebagai berikut:

1. Pemukiman $36,3 \%$

2. Perkebunan $3,1 \%$

3. Lahan Jasa $1,9 \%$

4. Sawah $6,1 \%$

5. Perusahaan $4,2 \%$

6. Kebun Campuran $45,4 \%$

7. Industri $1,5 \%$

8. Hutan Rawa 1,8 \% 
Jenis penggunaan tanah di Kota Medan didominasi pemanfaatan untuk Kebun Campuran 45,4 \%, pemukiman sebesar 36,3\%. Kemudian diikuti oleh penggunaan lain-lain seperti sawah 6,1\%, perusahaan $4,2 \%$, Perkebunan $3,1 \%$, lahan jasa $1,9 \%$, hutan rawa $1,8 \%$, dan industri $1,5 \%$ (52 ha) .

Kota Medan juga merupakan jalur sungai. Paling tidak ada 7 (tujuh) sungai yang melintasinya, yaitu :

- Sungai Belawan

- Sungai Badra

- Sungai Sikambing

- Sungai Putih

- Sungai Babura

- Sungai Deli

- Sungai Sulang-Saling/Sei Kera

Manfaat terbesar dari sungai-sungai ini adalah sebagai saluran pembuangan air hujan dan air limbah, bahkan sebenarnya potensial untuk dijadikan objek wisata sungai. Namun demikian pinggiran sungai juga berpotensi untuk menjadi daerah kumuh.

\section{e. Pelaksanaan Konsolidasi tanah}

\section{1) Horizontal}

Tabel 24. Lokasi Konsolidasi Tanah Perkotaan di Prop. Sumatera Utara

\begin{tabular}{|c|l|c|r|r|c|}
\hline No & \multicolumn{1}{|c|}{ Lokasi } & $\begin{array}{c}\text { Tahun } \\
\text { Pelaksanaan }\end{array}$ & $\begin{array}{c}\text { Jumlah } \\
\text { Bidang }\end{array}$ & $\begin{array}{l}\text { Jumlah } \\
\text { Perserta }\end{array}$ & Keterangan \\
\hline 1 & Simalungun & 1988 & 100 & 100 & $\begin{array}{c}\text { Perumahan } \\
\text { (APBN) }\end{array}$ \\
\hline 2 & Medan & 1990 & 318 & 318 & $\begin{array}{c}\text { Perumahan } \\
\text { (APBN) }\end{array}$ \\
\hline 3 & Siantar & 1992 & 416 & 335 & $\begin{array}{c}\text { Perumahan } \\
\text { (APBN) }\end{array}$ \\
\hline 4 & Tanah Tinggi & 1995 & 246 & 230 & $\begin{array}{c}\text { Perumahan } \\
\text { (Swadaya+APBN) }\end{array}$ \\
\hline 5 & Dairi & 1998 & 262 & 262 & $\begin{array}{c}\text { Perumahan } \\
\text { (APBN) }\end{array}$ \\
\hline 6 & Asahan & 2007 & 430 & 221 & $\begin{array}{c}\text { Perumahan } \\
\text { (swadaya) }\end{array}$ \\
\hline 7 & Medan & 2010 & 100 & 100 & $\begin{array}{c}\text { Perumahan } \\
\text { (APBN) }\end{array}$ \\
\hline
\end{tabular}

2) Vertikal

\section{a. Kebijakan}

Konsolidasi tanah Vertikal belum pernah dilaksanakan di Kota Medan. Pada tahun 2009 ada keinginan untuk melaksanakan Konsolidasi Tanah Perkotaan secara vertikal yang diinisiasi oleh Kementrian Perumahan Rakyat di kampung Aur, Kelurahan Aur, Kecamatan Medan 
Maimun dimana lokasinya merupakan daerah kumuh dengan padat penduduk namun tidak ditanggapi secara positif oleh masyarakat setempat, mereka lebih memilih untuk diberikan ganti rugi terhadap tanahnya. Tanah tersebut statusnya adalah tanah grant sultan yang sudah dikuasai oleh masyarakat selama puluhan tahun.

Yang sudah dibangun adalah rusunami dan rusunawa yang tersebar di beberapa wilayah di Kota Medan. Medan juga sudah mempunyai Peraturan daerah mengenai Rumah Susun. Rusunami di Kota Medan terdapat di dua lokasi yaitu :

- di kelurahan Sukaramai Kecamatan medan Area. Rusunami ini dibangun di atas tanah Hak Pengelolaan Pemerintah daerah dan dibangun oleh PT IRA.

- Di kelurahan Timbangdeli, kecamatan Medan Amplas, yang dibangun di atas tanah HGB Developer.

Perum Perumnas Regional I Sumbangut akan membangun empat tower rumah susun milik (Rusunami) di Medan pada 2011 yang diperkirakan mencapai 1.600 unit. General Manager (GM) Perum Perumnas Regional I (Aceh, Sumut, Sumbar, Kepri, dan Riau) Adil Manurung mengungkapkan pada 2011 BUMN perumahan itu akan membangun empat tower rusunami di Medan untuk memenuhi permintaan masyarakat yang meningkat. Pembangunannya mungkin baru bisa dimulai pada 2011 karena lokasinya adalah rumah susun Sukaramai sekarang ini sehingga warga yang selama ini tinggal di rusun Sukaramai harus dipindahkan dulu.

Persiapan untuk membangun empat tower berlantai 16 itu sudah dimulai pada 2010. Sedangkan sosialisasi kepada masyarakat dan rencana pemindahan sebanyak 416 kepala keluarga (KK) penghuni rumah susun sedang dimulai. Gedung rumah susun yang ditempati warga selama ini harus diruntuhkan karena lokasinya akan dibangun empat tower. Setiap tower akan dihuni 400 orang, sehingga total penghuni nantinya mencapai 1.600 kepala keluarga. Saat ini Perumnas sedang mengurus perizinan agar target awal 2011 bisa dimulai tender pembangunan fisik.

Rusunawa di Kota Medan terdapat di beberapa lokasi, antara lain :

- Kelurahan Sei Mati Kecamatan Medan labuhan, dibangun di atas Tanah Pemerintah Kota Medan, di lokasi ini dibangun 3 twin blockdengan luasan masing-masing unit $21 \mathrm{~m} 2$, dari 3 block yang sudah dibangun hanya 2 block yang sudah ditempati sedangkan 1 block masih dibiarkan kosong dan tidak terawat.

- Rusunawa di jalan kayu Putih, kelurahan tanjung Mulia, Kecamatan Medan Deli, juga dibangun di atas tanah pemerintah Kota Medan. Rusunawa ini juga belum digunakan sampai saat ini.

- Rusunawa yang dibangun untuk Universitas Sumatera Utara, UIN Medan dan UMSU Medan.

\section{b. Kondisi Lingkungan Pemukiman} sempit.

Merupakan perumahan padat dan kumuh dengan saluran air yang kecil dengan jalan yang 


\section{Palembang}

\section{a. Deskripsi Wilayah}

Kota Palembang terletak di antara 0252 - 0305 Lintang Selatan, dan di antara 10437 10452 Bujur Timur. Ketinggian diatas permukaan laut rata-rata 8 meter. Luas wilayah nya mencapai 37.403 Ha yang terdiri dari jumlah kecamatan sebanyak 16, dan jumlah kelurahan 107. Jumlah penduduk Kota Palembang tercatat sebanyak 1.611.094 jiwa.

Kota Palembang merupakan pusat pemerintahan Provinsi Sumatera Selatan dibatasi oleh:

Sebelah Utara $\quad$ : Kabupaten Banyuasin

Sebelah Selatan $\quad$ : Kabupaten Banyuasin, Ogan Ilir, Muara Enim

Sebelah Timur : Kabupaten Banyuasin

Sebelah Barat $\quad$ : Kabupaten Banyuasin

\section{b. Kepadatan Penduduk}

Tabel 25. Luas Wilayah Kota Palembang

\begin{tabular}{|c|l|l|}
\hline No. & Kecamatan & Luas $\mathbf{( k m 2 )}$ \\
\hline 1. & Plaju & 15,17 \\
\hline 2. & Seberang Ulu II & 10,69 \\
\hline 3. & Seberang Ulu I & 17,45 \\
\hline 4. & Kertapati & 42,56 \\
\hline 5 & Gandus & 68,78 \\
\hline 6. & llir Barat I & 19,77 \\
\hline 7 & llir Barat II & 6,22 \\
\hline 8 & Bukit Kecil & 9,92 \\
\hline 9. & llir Timur & 16,50 \\
\hline 10. & Kemuning & 9,00 \\
\hline 11. & llir Timur II & 25,58 \\
\hline 12. & Kalidoni & 27,92 \\
\hline 13. & Sako & 42,5 \\
\hline 14. & Sukarami & 1498,56 \\
\hline & Total & $\mathbf{4 0 0 , 6 2}$ \\
\hline
\end{tabular}

Sumber : Badan Pusat Statistik Kota Palembang, 2002

\section{c. Status Tanah}

Hak milik : 122.702 bidang

HGB : 23.979 bidang

Hak Pengelolaan $\quad$ : $\quad 8$ bidang

Hak Pakai $\quad$ : 2.714 bidang

\section{d. Peggunaan Tanah}

- Perumahan : 12.011 ha

- Jasa : 618 ha

- Perusahaan : 552 ha

- Industri : 544 ha

- Pertanian : 14.457 ha

- Lahan Kosong : 6.665 ha

- Lain-lain : 533 ha 


\section{e. Pelaksanaan Konsolidasi Tanah}

\section{1) Horizontal}

Konsolidasi tanah horizontal pernah dilaksanakan di Kota Palembang, yang dikenal sebagai Konsolidasi Tanah Perkotaan Kampung Teladan, Kelurahan Selabranti, Kec Seberang Ulu tahun 1999.

Semula merupakan tanah wakaf Yayasan Muhammaddiyah yang dibiarkan kosong sehingga diduduki oleh masyarakat sebagai tempat pemukiman selama bertahun-tahun, ada sekitar 264 warga dengan luas penguasaan rata-rata $200 \mathrm{~m} 2$ luas total \pm 4 hektar. Karena Yayasan Muhammadiyah akan memanfaatkan tanah tersebut masyarakat tidak mau digusur dari tanah yang telah diokupasi tersebut. Akhirnya diperoleh kesepakatan bahwa Yayasan Muhammadiyah bersedia melepaskan sebagian tanah tersebut untuk kepentingan masyarakat dengan pembagian rata-rata berkisar $\pm 108 \mathrm{~m} 2$ untuk memenuhi kebutuhan masyarakat untuk pemukiman melalui penataan Konsolidasi Tanah Perkotaan. Dalam kegiatan ini masyarakat memberikan uang kompensasi kepada Yayasan Muhammaduyah sebesar Rp. 500.000,- untuk setiapkapling. Kondisi saat ini merupakan daerah pemukiman padat, di bagian depan dan sekitarnya merupakan daerah yang cukup ramai untuk kepentingan rumah sakit dan pendidikan (universitas).

Adapun lokasi konsolidasi tanah horizontal seluruh Provinsi Sumatera Selatan lebih diarahkan di daerah kabupaten karena lebih mudah mencari obyek konsolidasi tanah.

Tabel 26. Lokasi Konsolidasi Tanah Perkotaan di Prop. Sumatera Selatan tahun 2009

\begin{tabular}{|c|c|c|c|c|c|}
\hline No. & L O K A S I & $\begin{array}{c}\text { Tahun } \\
\text { Pelaksanaan }\end{array}$ & L u a s M2) & $\begin{array}{l}\text { Jumlah } \\
\text { bidang }\end{array}$ & Keterangan \\
\hline 1 & $\begin{array}{l}\text { Desa Kencana Sari, Cempaka } \\
\text { Sakti, Sukohardjo, Cacar, Marga } \\
\text { Mulya, Lubuk layang, Muara } \\
\text { Danau dan Binjai, Kec. Zkikim, } \\
\text { Kab. Lahat }\end{array}$ & 2001 & 1500 & 750 & swadaya \\
\hline 2 & $\begin{array}{l}\text { OKU, OKI, Lahat, dan Musi } \\
\text { Banyuasin }\end{array}$ & 2002 & $\begin{array}{r}1.684,0023 \\
574,7679 \\
1.200,9422 \\
\end{array}$ & $\begin{array}{r}845 \\
280 \\
616 \\
8.574\end{array}$ & swadaya \\
\hline 3 & $\begin{array}{l}\text { OKU, OKI, Lahat, dan Musi } \\
\text { Banyuasin }\end{array}$ & 2003 & idem & & Swadaya \\
\hline 4 & OKI, Lahat, dan Musi Banyuasin & 2004 & & $\begin{array}{l}987 \\
856\end{array}$ & swadaya \\
\hline 5 & OKI & 2005 & & 423 & swadaya \\
\hline 6 & OKI, Muba, Banyuasin & 2006 & & 256 & Swadaya \\
\hline 7 & Prabumulih, OKI & 2008 & & 31 & Swadaya \\
\hline
\end{tabular}

\section{2) Vertikal}

\section{a. Kebijakan}

Pada tahun 2009, Pemerintah Kota Palembang merencanakan untuk melaksanakan konsolidasi tanah vertikal di Simpang Sungki, Kertapati, tanah ini merupakan asset tanah PT KAI dekat dengan Setasiun Kereta Kertapati yang telah diduduki oleh masyarakat sebagai 
tempat pemukiman selama bertahun-tahun dan saat ini sudah merupakan daerah pemukiman padat. Direncanakan akan ditata kembali dengan konsep konsolidasi vertikal namun belum diperoleh kesepakatan dari berbagaipihak terkait, dan saat ini ditangani oleh Menpera dan PT KAI Pusat namun belum diperoleh kesepakatan antara masyarakat, PT KAI dan Menpera.

Kemudian Pemerintah Kota Palembang pernah melakukan penataan kota melalui peremajaan kawasan kumuh di lokasi 12 Ulu, Palembang. Pendanaan dilakukan melalui Kredit Triguna dari BTN, dengan bunga $8.5 \%$ per tahun untuk 15 tahun. Biaya pelaksanaan : Rp 4,700,000.- s/d Rp 6,000,000.- 1998 (termasuk tanah).Peremajaan kota ini di laksanakan di atas tanah negara yang sudah dihuni selama lebih dari 30 tahun, setelah ditata ulang melalui peremajaan kota sebanyak 47 keluarga masyarakat mendapatkan hak atas tanahnya.

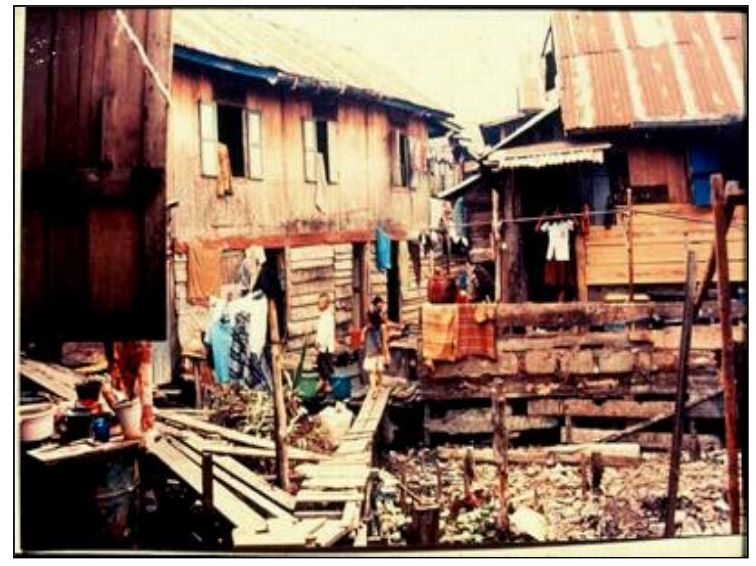

Gambar 12. sebelum penataan

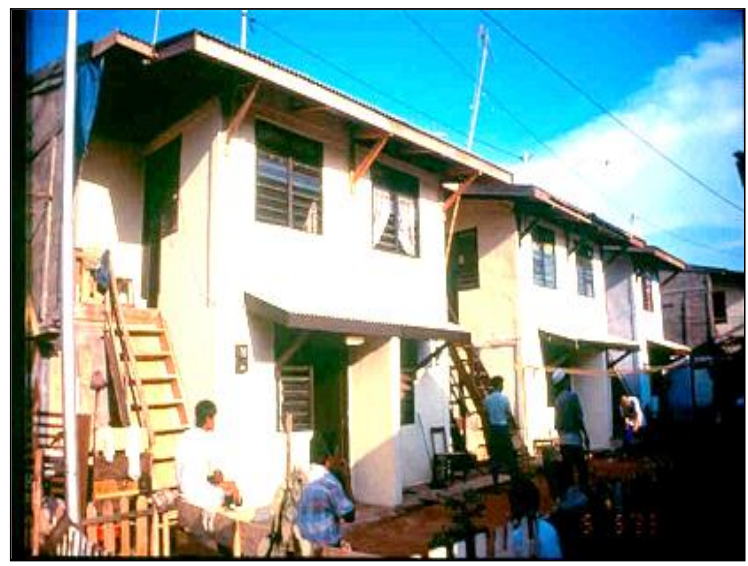

Gambar 13. sesudah penataan

Kedua pola di atas dapat dikatakan mendekati konsep konsolidasi tanah vertikal. Adapun lokasi rumah susun di kota Palembang antara lain :

\section{Rusunawa di Kasnariansyah}

Rusunawa Kasnariaansyah KM 4,5 Palembang milik Pemerintah Kota Palembang dibangun 4 lantai diatas tanah asset Pemda Kota Palembang pada tahun 2008, berjumlah 96 unit dengan ukuran kamar hunian $3 \times 7 \mathrm{M}^{2}$ (Type 21) dengan fasilitas air bersih PDAM, listrik 900 watt, area parkir yang luas, dan lantai dasar dilengkapi dengan sarana komersial (kios sembako dll) yang disewakan untuk ruang usaha dalam memenuhi kebutuhan pokok warga rusun, 4 unit dicadangkan sebagai "emergency room" apabila ada tamu penghuni dan atau perbaikan unit yang rusak, dan 1 gudang. Semula adalah tanah makam yang sudah dipindahkan kemudian dibangun Rusunawa yang pengelolaannya oleh PT Sarana Pembangunan Palembang Jaya (SP2J) di bawah Pemerintah Daerah Kota Palembang.

- Proses pembangunan rusun dilaksanakan dengan tahapan pemberian ganti-rugi asset yang dimiliki oleh masyarakat korban kebakaran dan sekitarnya, dengan nilai kompensasi yang ditaksir oleh Panitia 9 (Panitia Pembebasan Tanah);

- Tanah yang telah diganti rugi tersebut diberikan Hak Pengelolaan Kepada Perum Perumnas, dan untuk pembangunan rusun diberikan HGB 
2. Rusun Milik 24 Ilir Palembang dan 26 Ilir Palembang. Tahun 1984

- Lokasi ini semula merupakan daerah pemukiman yang padat sebagai daerah korban kebakaran

- Telah dihuni oleh masyarakat melebihi kapasitas yang menyebabkan kekumuhan di lokasi tersebut

- Menpera dan Pemerintah Kota Palembang tahun 1998 berinisiatif untuk membangun kawasan sersebut menjadi rumah susun milik untuk memenuhi kebutuhan masyarakat korban kebakaran dan masyarakat sekitar yang waktu itu cukup padat dan kumuh;

- Masyarakat korban kebakaran dan masyarakat sekitarnya diharapkan dapat ditampung dalam rumah susun tersebut;

- Pembangunan rusun dibangun 4 lantai dan pelaksanaan pembangunannya diserahkan kepada Perum Perumnas;

- Proses pembangunan rusun dilaksanakan dengan tahapan pemberian ganti-rugi asset yang dimiliki oleh masyarakat korban kebakaran dan sekitarnya, dengan nilai kompensasi yang ditaksir oleh Panitia 9 (Panitia Pembebasan Tanah);

- Tanah yang telah diganti rugi tersebut diberikan Hak Pengelolaan Kepada Perum Perumnas, dan untuk pembangunan rusun diberikan HGB

- Masyarakat yang mendapatkan ganti-rugi tersebut diberikan prioritas untuk memperoleh kembali Rusun setelah dibangun dengan cara membeli baik secara cash maupun angsuran/kredit, namun tidak semua masyarakat yang mendapatkan ganti-rugi tersebut mengambil kembali rusun tersebut, karena sebagian membeli tanah atau rumah di lokasi lain bukan rumah susun;

- Pembangunan rusun dibangun 4 lantai sebanyak 61 tower dengan berbagai type yaitu type 18 sebanyak 1634 unit, type 36 sebanyak 976 unit dan type 54 sebanyak 954 unit dengan jumlah 3564 unit

- Pengelolaan rusun semula dalam pengawasan dan bimbingan Perum Perumnas dibagi zone-zone untuk mengelola rusun tersebut, namun setelah lunas dan masyarakat mendapatkan hak milik atas satuan rumah susun tersebut pengawasan dan pengelolaannya diserahkan kepada masyarakat dan dikelola berdasarkan RT/RW;

- Fasos dan fasum diserahkan kepada Pemerintah Kota, (Tata Kota dan Tata Pemerintahan)

- Perlu peraturan daerah dalam mengatur rusun

- Pengelolaan rusun semula dibentuk PPRS (Persatuan Penghuni Rumah Susun) dibawah bimbingan dan pengawasan Perum Perumnas, hal ini hanya berlangsung selama 4 tahun;

- Pemilikan atas satuan rumah susun belum semua mendapatkan Sertipikat;

- Yang sudah lunas angsuran pembayaran rusun memperoleh sertipikat atas satuan rumah susun yang pada awalnya masih dikelola oleh Perum Perumnas, untuk yang belum lunas kreditnya dilanjutkan melalui Bank BTN; 
- Pada awalnya telah dibentuk Pengurus Perhimpunan Penghuni Rumah Susun (PPRS) oleh Dewan Formatur yang terdiri dari unsur-unsur DRPD, Pengurus PPRS, dan Unsur PAB. Pembentukan PPRS dibagi dalam 4 (empat) zona dan masing-masing zona dibentuk PPRS. Tim Formatur ini oleh rapat pleno pengurus bersama Perwakilan Antar Blok diberi mandat penuh untuk menyusun, memilih dan menetapkan Ketua, Wakil Ketua dan kepengurusan PPRS;

- Untuk pembiayaan pengelolaan tersebut pada tahap awal Perum Perumnas memberikan bantuan pembiayaan sebesar Rp. 3 juta ruapiah setiap bulan untuk biaya pengelolaan dan pemeliharaan setiap zona, hal ini diharapkan nantinya PPRS dapat mencari sumber dana sendiri dan dapat mandiri dalam pengelolaan tersebut;

- Pengelolaan fasilitas umum/sosial/bersama rusun palembang telah diserahkan oleh Perum Perumnas kepada Pemda, sehingga kewenangan pengelolaan dan pemanfaatanya menurut Direktur Perum Perumnas merupakan kewenangan Pemda dengan persetujuan masyarakat penghuni rumah susun.

- Setelah tidak mendapatkan bantuan dana dari Perum Perumnas dan PPRS tidak ada dan tidak berfungsi lagi perbaikan lingkungan hanya dilakukan kalau ada bantuan dari P2KP (Program Pemberdayaan Kemiskinan Perkotaan) untuk perbaikan gang dan saluran

- Masyarakat banyak memanfaatkan fasilitas umum/sosial/bersama untuk kepentingan pribadi, misal yang tadinya untuk troroar dan tempat parkir di sekitar bangunan rusun khususnya lantai dasar sudah banyak dibangun untuk keperluan pribadi, bahkan ada yang membangun lebih dari 1 lantai;

- Terjadinya penambahan bangunan ini pada awalnya dimulai dengan membuat teras-teras di depan rumah khususnya di lantai satu tanpa pagar, kemudian dibuat pagar dan akhirnya dibangun tembok rapat dan dijadikan ruang tamu atau ruang usaha. Hal ini pada awalnya sering ditertibkan oleh Perum Perumnas dan di bongkar, namun setelah pengelolannya diserahkan ke Pemda dan sebagian hunian tersebut adalah orang-orang Pemda, mereka tidak dapat melarang dan membongkar. Hal ini memberikan contoh yang kurang baik kepada penghuni lainnya

- Bangunan tambahan tersebut tidak dapat dilarang baik oleh penghuni lainnya dengan alasan sebagai tempat usaha tambahan (ruang usaha/restoran/ warung/bengkel/kamar sewa/dll) di sisi lain Lurah dan camat serta pihak lainnya menurut informasi dilapangan memberikan ijin untuk usaha tersebut;

- Fasilitas taman, tanah kosong, dan ruang bersama banyak dimanfaatkan sebagai fasilitas pribadi; 


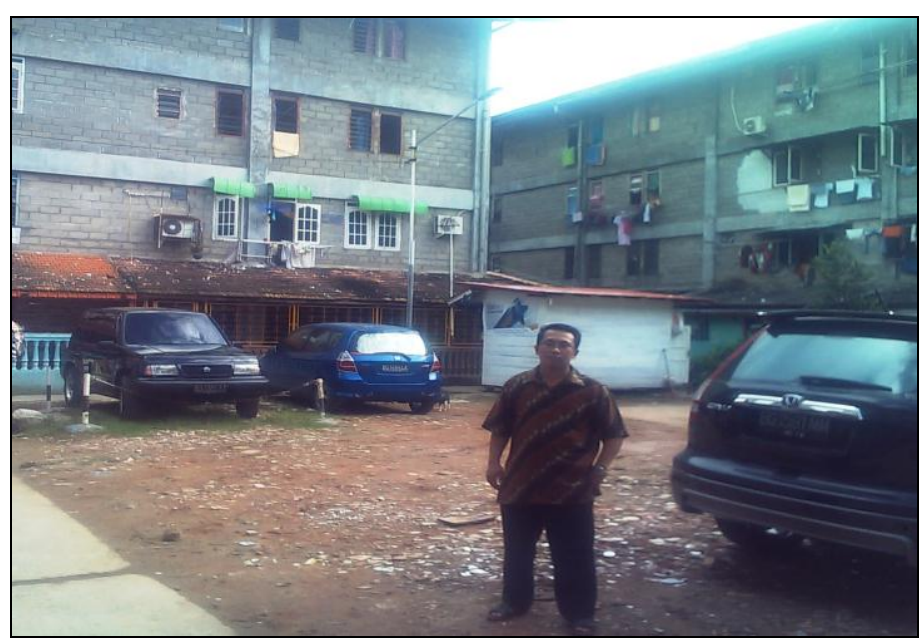

Gambar 14. Pemanfaatan fasilitas umum/taman bermain untuk tempat parkit dan ruang usaha

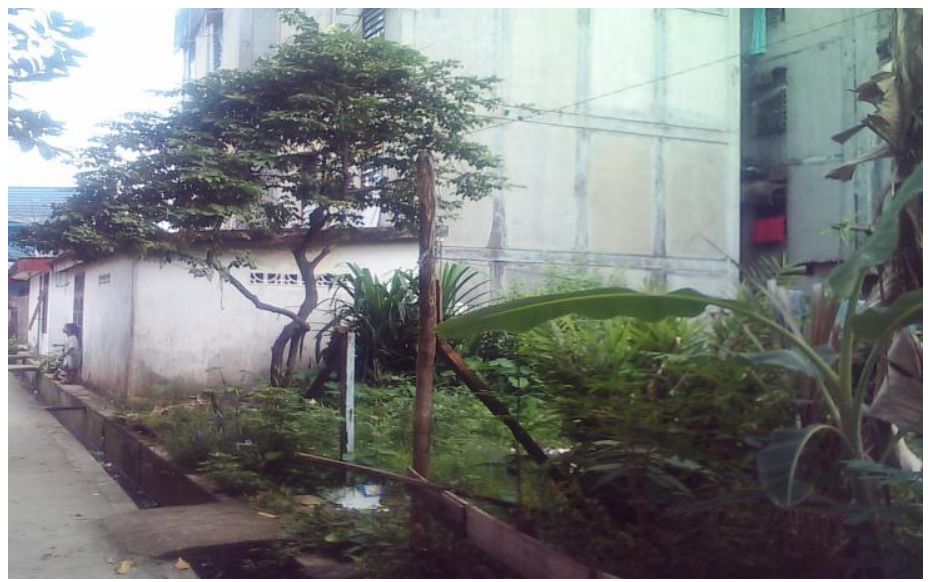

Gambar 15. Pemanfaatan fasilitas bersama untuk bangunan di lantai I dan lahan terbuka yang dibiarkan menjadi semak belukar dan tidak terawat (kumuh).

- Taman bermain anak dan tempat rekreasi yang semula dapat dinikmati oleh masyarakat penghuni rusun, diambil alih oleh pihak ke tiga untuk pembangunan Hotel Grand Duta, menurut salah satu responden masyarakat tidak dapat menolak karena menyangkut ijin dari pejabat yang terlibat di dalamnya;

- Contoh lain adalah pemanfaatan secara pribadi khususnya yang berada di lantai dasar dengan mengkapling dan membangun areal kosong untuk kebutuhan ruang pribadi sebagai tempat usaha, kios, toko, bengkel, dan usaha lainya; 


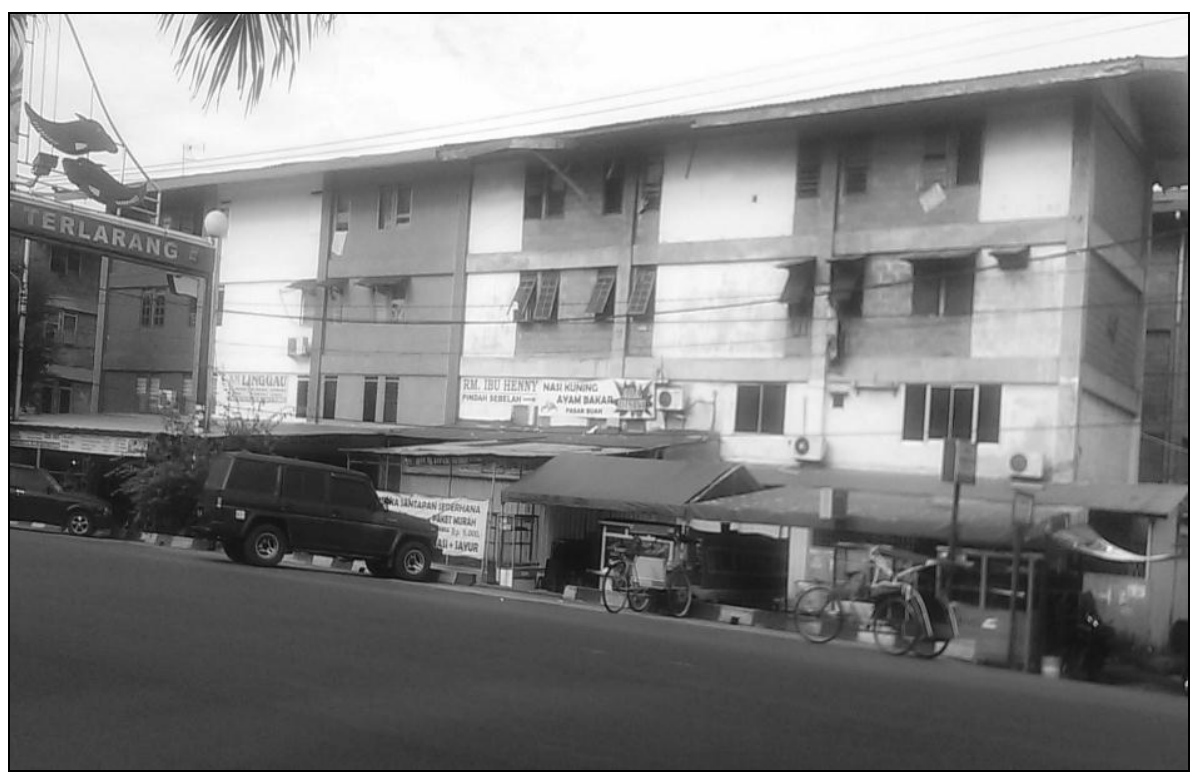

Gambar 16. Pemanfaatan fasilitas bersama di lantai I untuk ruang usaha pribadi

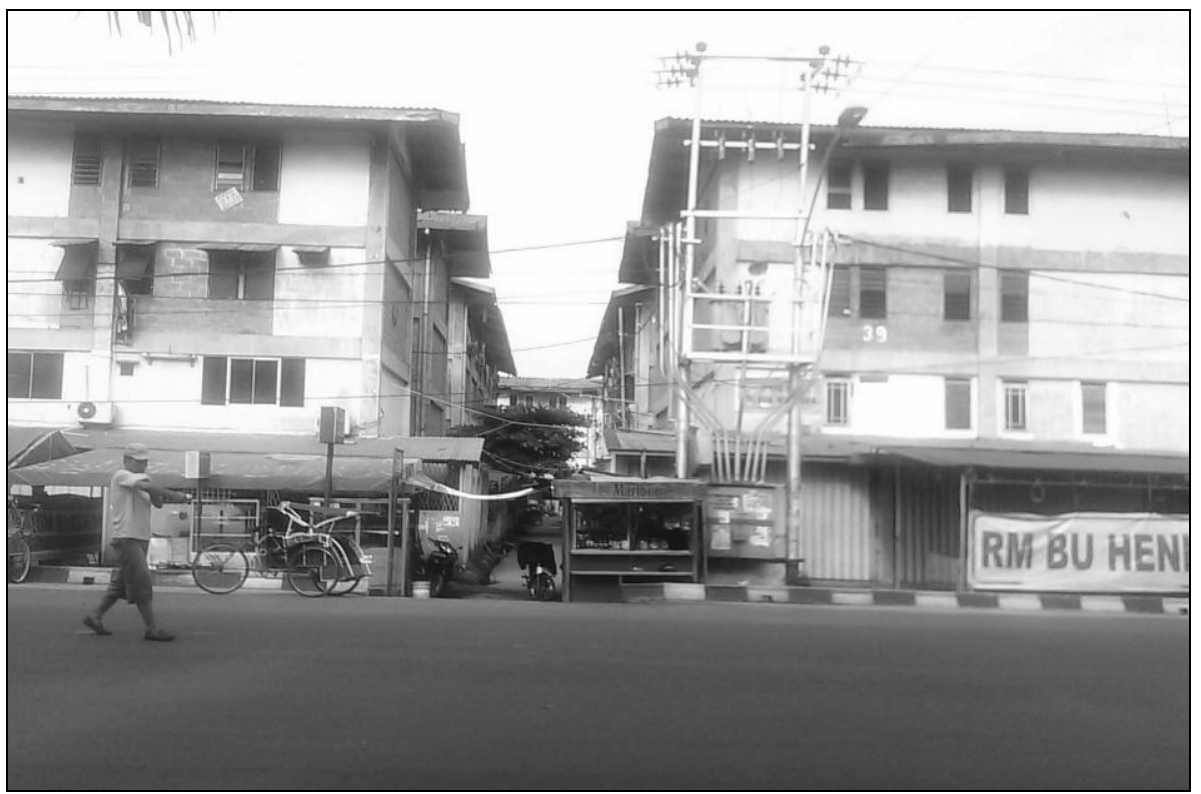

Gambar 17. Pemanfaatan fasilitas bersama di lantai I untuk rumah makan

- Pada awalnya sudah ada tata tertib dan larangan dalam penghunian rumah susun yang tertuang dalam Anggaran Dasar dan Anggaran Rumah Tangga PPRS, namun karena PPRS sudah tidak berfungsi lagi maka terjadilah hal yang demikian. Tata tertib penghunian tersebut sifatnya mengikat dan harus ditaati oleh subyek hukum yang memiliki, memakai, menyewa, menyewa beli atau yang memanfaatkan, termasuk penyelenggara pembangunan satuan rumah susun;

- Demikian pula ada hak dan kewajiban yang harus diikuti, antara lain hak mendapatkan perlindungan dan hak untuk memanfaatkan rumah susun dan lingkungannya sesuai dengan ketentuan peruntukan yang telah ditentukan secara tertib dan benar termasuk 
bagian bersama, benda bersama dan tanah bersama dengan tidak melakukan penambahan yang menimbulkan kerugian bagi pemilik lainnya, dan setiap anggota/penghuni dilarang :

○ melakukan perbuatan yang membahayakan keamanan, ketertiban dan keselamatan penghuni lain, bangunan dan lingkungannya;

- mengubah bentuk dan atau menambah bangunan di luar satuan unit rumah susun yang dimiliki tanpa tanpa mendapat persetujuan perhimpunan penghuni;

- Di samping itu ada larangan-larangan yang seharusnya dipatuhi antara lain : Setiap penghuni yang memiliki, memakai, menyewa, menyewa beli atau yang memanfaatkan, termasuk penyelenggara pembangunan satuan rumah susun dilarang :

- Menjadikan satuan rumah susun sebagai tempat usaha atau sebagai tempat yang bertentangan dengan susila, norma Agama, Adat istiadat, dan segala tindakan yang bertentangan dengan peraturan perundangan yang berlaku, kecuali satuan rumah susun yang berfungsi membantu kelancaran program pengelolaan perumahan yang mendapat ijin dari Pemerintah;

- Menambah dan merubah bentuk bangunan di luar satuan rumah susun baik untukkepentingan pribadi ataupun kepentingan bersama, tanpa persetujuan tertulis dari PPRS dan dibenarkan oleh peraturan perundangan uang berlaku;

- Menjadikan dan menambah sebagian atau seluruhnya untuk kepentingan pribadi terhadap teras, tangga, ruang antar blok, halaman di lantai dasar sebagaimana yang tercantum dalam bagian bersama, benda bersama dan tanah berasama;

- Mengambil manfaat secara tidak syah atas aliran listrik dan air minum;

○ Memelihara hewan peliharaan;

- Memagari halaman, tanah kosong atau taman sehingga menghalangi dan menghilangkan pemanfaatan bersama atas bagian bersama, benda bersama dan tanah berasama;

- Menutup atau mengubah fungsi bagian bersama, benda bersama dan tanah berasama, di luar fungsinya sebagaimana dimaksud dalam pertelaan dan perencanaan pembangunan yang telah dibuat oleh penyelenggara pembangunan yang disyahkan oleh pemerintah.

Saat ini Pemerintah Daerah Kota Palembang sedang merencanakan peremajaan Rumah Susun 24 dan 26 Ilir Palembang tersebut dan direncanakan akan ditingkatkan menjadi 12 tingkat yang semula hanya 4 tingkat, karena bangunannya sudah tua dan kondisinya sudah kumuh di tengahtengah Kota Palembang. Sehingga model konsolidasi tanah yang akan dilakukan adalah dari vertikal ke vertikal.

\section{b. Kondisi Lingkungan Pemukiman}

Merupakan pemukiman padat penduduk dengan sarana jalan yang sempit, dan saluran air yang kecil/sempit. 


\section{Makassar}

\section{a. Deskripsi Wilayah}

Kota Makassar terletak antara 119²4'17'38” Bujur Timur dan 5 ${ }^{\circ} 8^{\prime} 6^{\prime} 19^{\prime}$ Lintang Selatan yang Lintang Selatan yang berbatasan sebelah utara dengan Kabupaten Maros, sebelah timur Kabupaten Maros, sebelah selatan Kabupaten Gowa dan sebelah barat adalah Selat Makassar. Luas Wilayah Kota Makassar tercatat $175,77 \mathrm{~km}$ persegi yang meliputi 14 kecamatan dimana kecamatan yang memiliki luas wilayah yang paling besar adalah kecamatan Biring kanaya sedangkan terkecil adalah kecamatan Mariso.

\section{b. Kepadatan Penduduk}

Penduduk Kota Makassar tahun 2008 tercatat sebanyak 1.253.656 jiwa yang terdiri dari 601.304 laki-laki dan 652.352 perempuan. Sementara itu jumlah penduduk Kota Makassar tahun 2007 tercatat sebanyak 1.235.239 jiwa. Komposisi penduduk menurut jenis kelamin dapat ditunjukkan dengan rasio jenis kelamin Rasio jenis kelamin penduduk Kota Makassar yaitu sekitar 92.17 persen, yang berarti setiap 100 penduduk wanita terdapat 92 penduduk laki-laki Penyebaran penduduk Kota Makassar dirinci menurut kecamatan, menunjukkan bahwa penduduk masih terkonsentrasi diwilayah kecamatan Tamalate, yaitu sebanyak 152.197 atau sekitar 12,14 persen dari total penduduk, disusul kecamatan Rappocini sebanyak 142.958 jiwa (11,40 persen). Kecamatan Panakkukang sebanyak 134.548 jiwa (10,72 persen), dan yang terendah adalah kecamatan Ujung Pandang sebanyak 28.637 jiwa (2,28 persen).

Tabel 27. Presentase Penduduk dan Kepadatan Penduduk Menurut Kecamatan di Kota Makassar

\begin{tabular}{|c|c|c|c|}
\hline \multirow{2}{*}{$\begin{array}{l}\text { KODE } \\
\text { WIL } \\
\text { Area } \\
\text { Code }\end{array}$} & \multirow{2}{*}{$\begin{array}{l}\text { KECAMATAN } \\
\text { Subdistricts }\end{array}$} & $\begin{array}{c}\text { PERSENTASE } \\
\text { PENDUDUK } \\
\text { Percentage of Population }\end{array}$ & $\begin{array}{l}\text { KEPADATAN PENDUDUK } \\
\text { Population density (PerKm2) }\end{array}$ \\
\hline & & 2008 & 2008 \\
\hline (1) & (2) & (5) & $(8)$ \\
\hline 010 & MARISO & 4,36 & 30.009 \\
\hline 020 & MAMAJANG & 4,82 & 26.842 \\
\hline 030 & TAMALATE & 12,14 & 7.531 \\
\hline 031 & RAPPOCINI & 11,40 & 15.488 \\
\hline 040 & MAKASSAR & 6,61 & 32.900 \\
\hline 050 & UJUNG PANDANG & 2,28 & 10.889 \\
\hline 060 & WAJO & 2,79 & 17.593 \\
\hline 070 & BONTOALA & 4,93 & 29.433 \\
\hline 080 & UJUNG TANAH & 3,86 & 8.145 \\
\hline 090 & TALLO & 10,79 & 23.210 \\
\hline 100 & PANAKKUKANG & 10,73 & 7.891 \\
\hline 101 & MANGGALA & 7,90 & 4.101 \\
\hline 110 & BIRINGKANAYA & 10,27 & 2.670 \\
\hline 111 & TAMALANREA & 7,11 & 2.800 \\
\hline 7371 & MAKASSAR & 100,00 & 7.132 \\
\hline
\end{tabular}

Sumber: Makasar dalam angka 2009 
Ditinjau dari kepadatan penduduk kecamatan Makassar adalah terpadat yaitu 32.900 jiwa per km persegi, disusul kecamatan Mariso (30.009 jiwa per km persegi), kecamatan Bontoala (29.433 jiwa per km persegi). Sedang kecamatan Biringkanaya merupakan kecamatan dengan kepadatan penduduk terendah yaitu sekitar 2.670 jiwa per km persegi, kemudian kecamatan Tamalanrea (2.800 jiwa per km persegi), Manggala (4.101 jiwa per km persegi), kecamatan Ujung Tanah (8.145 jiwa per km persegi), kecamatan Panakkukang 7.891 jiwa per km persegi. Wilayah-wilayah yang kepadatan penduduknya masih rendah tersebut masih memungkinkan untuk pengembangan daerah pemukiman terutama di 3 (tiga) kecamatan yaitu Biringkanaya, Tamalanrea, Manggala.

\section{c. Penguasaan dan Pemilikan Tanah}

Penguasaan/ Pemilikan Tanah yang telah memperoleh sertifikat di Kota Makassar yang diterbitkan sejak tahun 1960 antara lain:

Tabel 26. Penguasaan dan Pemilikan Tanah Kota Makassar

\begin{tabular}{|c|c|c|c|}
\hline No & Jenis Hak & $\begin{array}{l}\text { Jumlah } \\
\text { (Bidang) }\end{array}$ & $\begin{array}{l}\text { Luas } \\
\left(\mathrm{m}^{2}\right)\end{array}$ \\
\hline 1 & Hak Milik & 85.550 & 21.105 .334 \\
\hline 2 & Hak Guna Bangunan & 44.196 & 59.542 .396 \\
\hline 3 & Hak Guna Usaha & 0 & 0 \\
\hline 4 & Hak Pakai & 2.362 & 14.732 .708 \\
\hline 5 & Hak Pengelolaan & 62 & 12.649 .053 \\
\hline 6 & HMSRS & 6.931 & 0 \\
\hline & Jumlah & 139.101 & 108.029 .491 \\
\hline
\end{tabular}

Sumber : Kantor Pertanahan Kota Makassar, 2010

\section{d. Penggunaan dan Pemanfaatan Tanah}

Jenis penggunaan tanah di Kota Makassar pada tahun 2008 didominasi pemanfataan untuk pemukiman/perumahan. Berdasarkan tabel tersebut menunjukan bahwa sebagian besar penggunaan tanahnya untuk pemukiman sekitar $65 \%$ (11.102,6 ha) kemudian diikuti oleh sawah $11 \%$ (1.830,3 ha), tanah kering 8\% (1.333,5 ha), perairan 6\% (1.027,2 ha), industri 6\% $(957,1$ ha), perkebunan $2 \%$ (400,6 ha) dan lahan kosong $2 \%$ (393 ha).

Tabel 27. Jenis Penggunaan Tanah di Kota Makassar

\begin{tabular}{|c|l|r|}
\hline No & \multicolumn{1}{|c|}{ Jenis Hak } & \multicolumn{1}{c|}{ Luas (ha) } \\
\hline 1 & Pemukiman/Perumahan & $11.102,6$ \\
\hline 2 & Sawah & $1.830,3$ \\
\hline 3 & Tanah Kering & $1.333,5$ \\
\hline 4 & Perairan & $1.027,2$ \\
\hline 5 & Industri & 957,1 \\
\hline 6 & Perkebunan & 400,6 \\
\hline 7 & Lahan Kosong & 393 \\
\hline
\end{tabular}




\section{e. Pelaksanaan Konsolidasi Tanah}

\section{1) Horizontal}

Konsolidasi tanah perkotaan di Kota Makassar dilaksanakan oleh Kanwil BPN dan dibiayai oleh Dipa BPN-RI yang bersumber dari APBN dan swadaya masyarakat melalui PNBP. Konsolidasi tanah tersebut dilaksanakan di Desa Tamangamang, Kecamatan Manggala pada tahun 2001. Dengan luas 2,1789 ha sebanyak 94 bidang dengan peserta 94 orang.

Secara keseluruhan hasil Konsolidasi Tanah Horisontal di Sulawesi Selatan dari tahun 1985 s/d 2009 adalah sebagai berikut:

Tabel 28. Pelaksanaan Konsolidasi Tanah Prov. Sulawesi Selatan

\begin{tabular}{|c|l|r|r|r|r|}
\hline No & \multicolumn{1}{|c|}{ Kab/Kota } & \multicolumn{1}{c|}{ Luas (ha) } & \multicolumn{1}{c|}{ Peserta } & \multicolumn{1}{c|}{ Persil } & \multicolumn{1}{c|}{ STUP (ha) } \\
\hline 1 & Barru & 19,6400 & 589 & 569 & 3,5788 \\
\hline 2 & Luwu & 141,0000 & 250 & 250 & 14,1000 \\
\hline 3 & Luwu Timur & 668,4631 & 805 & 805 & 86,8679 \\
\hline 4 & Pare-Pare & 50,6000 & 303 & 354 & 8,6020 \\
\hline 5 & Ujungpandang & 2,1789 & 69 & 94 & 0,5163 \\
\hline 6 & Bulukumba & 133,0000 & 990 & 1.426 & 13,6000 \\
\hline 7 & Sinjai & 78,7212 & 425 & 575 & 14,0080 \\
\hline 8 & Jeneponto & 92,4841 & 477 & 492 & 20,0583 \\
\hline 9 & Pinrang & 80,0000 & 105 & 105 & 12,0000 \\
\hline 10 & Pangkep & 13,0000 & 126 & 126 & 2,9270 \\
\hline & Total & $1.279,0873$ & 4.119 & 4.796 & 176,2583 \\
\hline
\end{tabular}

\section{2) Vertikal}

\section{a) Kebijakan}

Sampai saat ini Kota Makassar belum pernah melaksanakan konsolidasi tanah secara vertikal. Yang sudah berjalan adalah pembangunan rumah susun sewa, adapun lokasi rusunawa tersebar di wilayah :

- Kelurahan Daya Kecamatan Biringkanaya dengan luas lahan 25,606 $\mathrm{m}^{2}$ karena di lokasi ini banyak masyarakat yang membutuhkan perumahan. Mereka itu terdiri dari pekerja pada Kawasan Industri Makassar (KIMA), Pekerja/Karyawan Terminal Regional Daya, Pedagang Asongan yang berjualan di sekitar Pasar Daya yang karena kegiatannya sangat membutuhkan hunian di lokasi tersebut.

Untuk itu telah dibangun 1 (satu) Twin Blok, yang terdiri dari 2 (dua) inti bangunan dengan jumlah 96 kamar hunian. Rumah Susun Sederahana Sewa (Rusunawa) Daya di bangun pada tahun 2003 dan selesai Tahun 2005 dan telah diresmikan oleh Menteri Negara Perumahan Rakyat, sedangkan pengoperasiannya diresmikan pada tanggal 16 April 2005 oleh Pemerintah Kota Makassar. Perlu ditambahkan bahwa di lokasi yang sama (Daya) telah dibangun lagi 1 (satu) Twin Blok yang terdiri dari 2 unti bangunan dengan jumlah 96 kamar hunian yang sedang dalam tahap pelaksanaan dan akan dioperasionalkan Tahun 2008. 
Tabel 29. Tarif Sewa Rumah Susun Sederhana Sewa Daya

\begin{tabular}{|c|l|c|}
\hline No & \multicolumn{1}{|c|}{ Lantai } & Harag Sewa/bulan \\
\hline 1 & Dasar & Fasilitas Umum \\
\hline 2 & I & Rp.150.000,- \\
\hline 3 & II & Rp.125.000,- \\
\hline 4 & III & Rp.100.000,- \\
\hline 5 & IV & Rp. 75.000,- \\
\hline
\end{tabular}

Gambar 18. Rumah Susun Sederhana Sewa (Rusunawa) Daya
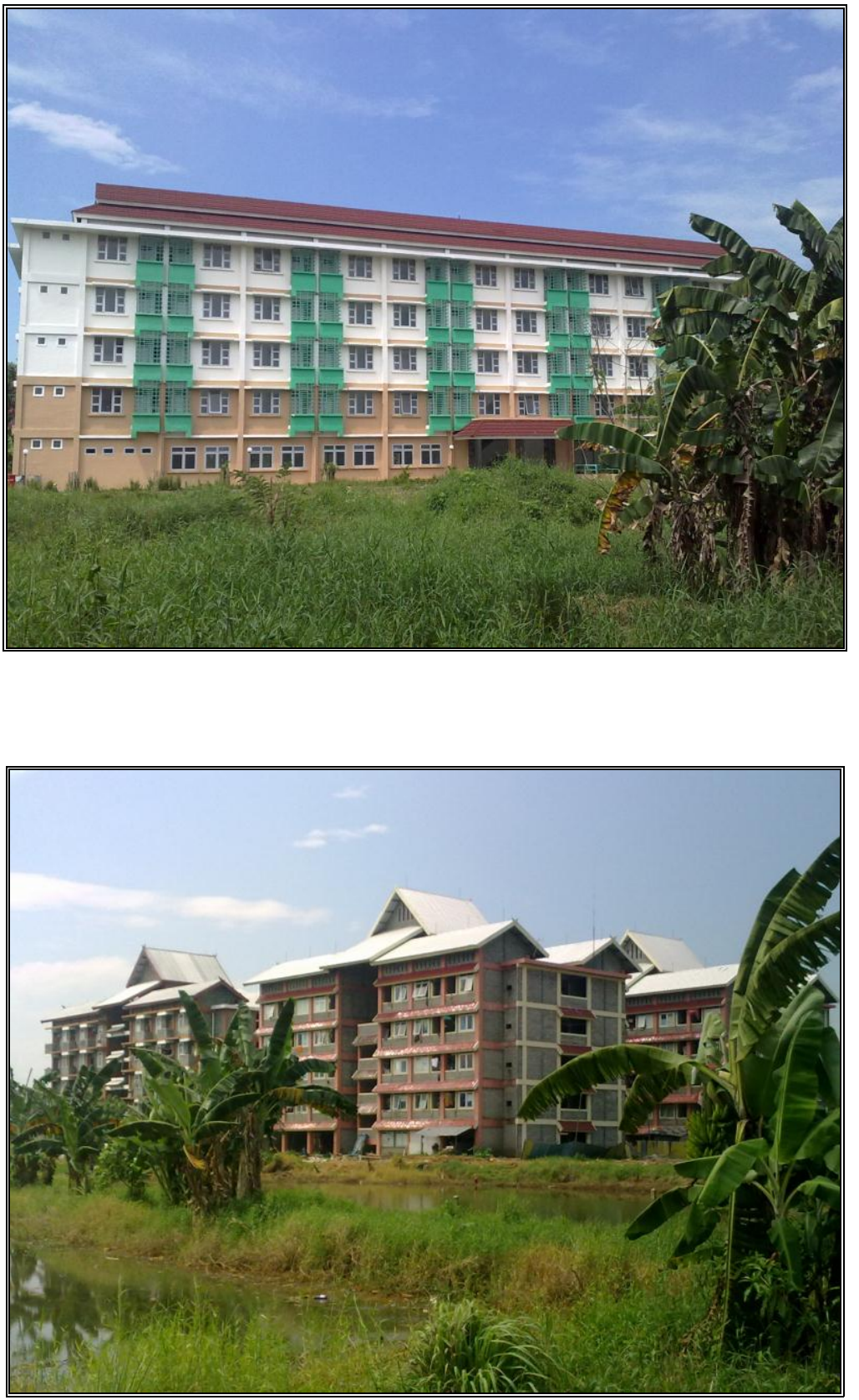
- Kelurahan Mariso yang dikenal sebagai Rusunawa Mariso kini telah rampung dan siap dioperasikan sebanyak 3 (tiga) Twin Block, dengan jumlah hunian sebanyak 288 kamar. Dimana diperuntukan untuk masyarakat nelayan, dan Masyarakat Berpenghasilan Rendah (MBR) yang bermukim di sekitar RUSUNAWA Mariso di 3 (tiga) Kelurahan yaitu Kel. Lette, Kel. Pannambungan dan Kel. Mariso yang kini masih dalam tahap proses sosialisasi penetapan penghuni dan tarif sewa penghunian. Pendataan calon penghuni dilibatkan ketua RT/RW di 3 (tiga) kelurahan tersebut, yang telah mendaftaran sebanyak 536 calon penghuni.

\section{b) Kondisi Lingkungan Pemukiman}

Rumah sangat padat dan ukurannya kecil-kecil, saluran air berukuran kecil dan tidak beraturan, demikian juga jalan sempit dan tidak beraturan.

\section{Banjarmasin}

\section{a. Deskripsi Wilayah}

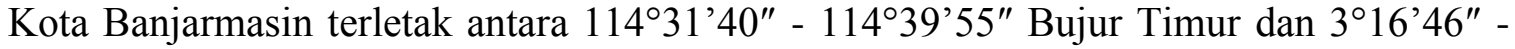
$3^{\circ} 22^{\prime} 54^{\prime \prime}$ Lintang Selatan dengan luas wilayah 72,00 $\mathrm{Km}^{2}$, yang terbagi atas 5 kecamatan dan 50 kelurahan, berada di ujung Selatan Propinsi Kalimantan Selatan di dekat Sungai Barito dibelah oleh Sungai Martapura. Secara administratif Kota Banjarmasin terdiri dari 5 kecamatan dan 50 kelurahan dengan batas wilayah :

\section{Batas Wilayah Administrasi}

Sebelah Utara $\quad$ : Kabupaten Barito Kuala.

Sebelah Timur $\quad$ : Kabupaten Banjar.

Sebelah Selatan : Kabupaten Banjar.

Sebelah Barat $\quad$ : Kabupaten Barito Kuala.

Wilayah Kota Banjarmasin secara topografi terletak pada ketinggian 0,16 meter di bawah permukaan laut atau merupakan daerah dataran yang terdiri dari rawa-rawa atau sering disebut sebagai daerah dataran banjir dengan luas wilayah $72 \mathrm{~km}^{2}$. Dibelah oleh Sungai Martapura dan dipengaruhi oleh pasang surut air laut Jawa, sehingga berpengaruh kepada drainase kota mapun memberikan ciri khas tersendiri terhadap kehidupan masyarakat, terutama pemanfaatan sungai sebagai salah satu prasarana transportasi air, pariwisata, perikanan dan perdaganan, oleh karena itu Kota Banjarmasin memiliki suhu udara yang panas dengan suhu rata-rata $25-38^{\circ} \mathrm{C}$ dengan curah hujan bulanan rata-rata sekitar $236 \mathrm{~mm}$ dan jumlah hari hujan berkisar 157 hari per tahun. Wilayah kota Banjarmasin pada bagian Utara dibatasi Kabupaten Barito Kuala, bagian Timur oleh Kabupaten Banjar, bagian Barat oleh Kabupaten Barito Kuala dan bagian Selatan dibatasi oleh Kabupaten Banjar.

Wilayah Kota Banjarmasin dibagi dalam 5 kecamatan dan 50 kelurahan dengan jumlah penduduk pada tahun 2008 mencapai 627.245 jiwa terdiri dari penduduk laki-laki 313.489 jiwa dan 313.756 jiwa perempuan. Dengan luas wilayah $72,00 \mathrm{Km}^{2}$, sehingga berdasarkan wilayah kecamatan maka hampir sekitar $48 \%$ penduduk Kota Banjarmasin berdiam di Kecamatan 
Banjarmasin Selatan dan Banjarmasin Barat dengan tingkat kepadatan penduduk terbesar pada Kecamatan Banjarmasin Barat yang mencapai 11.201 jiwa $/ \mathrm{km}^{2}$.

\section{b. Kepadatan Penduduk}

Jumlah penduduk di Kota Banjarmasin dari tahun ke tahun terus mengalami peningkatan dari faktor kelahiran, datang, kematian dan pergi. Berdasarkan hasil Sensus Penduduk 2008, penduduk Kota Banjarmasin berjumlah 627.245 orang yang terdiri dari 313.489 orang (24,76 persen) laki-laki dan 313.756 orang (50,02 persen) perempuan. Berdasarkan hasil Sensus Penduduk 2008 jumlah penduduk tercatat 627.245 orang. Komposisi penduduk berdasarkan jenis kelamin adalah 24,76 persen laki-laki dan 50,02 persen perempuan. Secara keseluruhan jumlah penduduk perempuan lebih tinggi dibandingkan dengan penduduk laki-laki seperti tampak dari rasio jenis kelamin penduduk yang lebih kecil dari 100. Rasio jenis kelamin adalah perbandingan antara banyaknya penduduk laki-laki dengan penduduk perempuan pada suatu daerah dan waktu tertentu.

Biasanya dinyatakan dengan banyaknya penduduk laki-laki untuk 100 penduduk perempuan. Dengan luas wilayah 72,00 $\mathrm{Km}^{2}$, kepadatan penduduk Kota Banjarmasin 8,712 jiwa/km².

Tabel 30. Kepadatan Penduduk Kota Banjarmasin

\begin{tabular}{|c|c|c|c|c|c|c|}
\hline No. & Kecamatan & $\begin{array}{c}\text { Luas } \\
\text { Wilayah }\end{array}$ & Laki-Laki & Perempuan & Jumlah & $\begin{array}{l}\text { Kepadatan } \\
\text { Penduduk }\end{array}$ \\
\hline 1. & Banjarmasin Selatan & 20,18 & 75.079 & 75.142 & 150.221 & 7,444 \\
\hline 2. & Banjarmasin Timur & 11,54 & 59.113 & 59.165 & 118.278 & 10,249 \\
\hline 3. & Banjarmasin Barat & 13,37 & 74.845 & 74.908 & 149.753 & 11,201 \\
\hline 4. & Banjarmasin Tengah & 11,66 & 57.268 & 57.316 & 114.584 & 9,827 \\
\hline 5. & Banjarmasin Utara & 15,25 & 47.184 & 47.225 & 94.409 & 6,209 \\
\hline & J U M L A H & 72,00 & 313.489 & 313.756 & 627.245 & 8,712 \\
\hline
\end{tabular}

Sumber Badan Pusat Statistik Kota Banjarmasin, 2009

\section{c. Status Tanah}

Status tanah yang ada di Banjarmasin, antara lain :

- Hak Milik (bekas agrarisch eigendom)

- Hak Guna Bangunan

- Hak Pakai yang diberikan kepada perorangan dan Instansi pemerintah selama diperlukan

- Hak Pengelolaan

\section{d. Penggunaan Tanah}

Penggunaan tanah di Kota Banjarmasin Tahun 2008 untuk lahan pertanian seluas 1.362 Ha, Industri $135 \mathrm{Ha}$, Jasa $536 \mathrm{Ha}$ dan Tanah Perumahan 2.653,5 Ha. Dibandingkan dengan data tahun-tahun sebelumnya lahan pertanian cendrung menurun, sementara untuk lahan perumahan mengalami perluasan sejalan dengan peningkatan kegiatan ekonomi dan pertumbuhan penduduk. 
Tabel 31. Luas Penggunaan Lahan Per Kecamatan di Kota Banjarmasin Tahun 2008

\begin{tabular}{|c|l|r|r|}
\hline No. & \multicolumn{1}{|c|}{ Penggunaan Tanah } & \multicolumn{2}{c|}{ Luas (Ha) } \\
\hline 1. & Pemukiman & $2.653,5$ & 36,8 \\
\hline 2. & Industri & 135 & 1,8 \\
\hline 3. & Jasa & 536 & 7,4 \\
\hline 4. & Sawah & 1.362 & 18,9 \\
\hline 5. & Kebun & 780,8 & 10,8 \\
\hline 6. & Semak Belukar & 178 & 2,5 \\
\hline 7. & Lain-Lain & $1.548,35$ & 21,5 \\
\hline & Jumlah & 7193,65 & 99,7 \\
\hline
\end{tabular}

Sumber: Kantor Pertanahan Kota Banjarmasin, Tahun 2009

\section{e. Pelaksanaan Konsolidasi Tanah}

\section{1) Horizontal}

Lokasi kegiatan konsolidasi tanah di Kota Banjarmasin pada tahun 2009 terletak di kelurahan kelayan Selatan, kecamatan Banjarmasin Selatan dengan luas 13,5 ha.

Jenis penggunaan tanah di lokasi tersebut antara lain :

- Sawah ditanami padi dan kelapa, luas $\pm 13,43$ ha $(99,48 \%)$

- Sutet (tower transmisi PLN), luas $\pm 0,02$ ha $(0,15 \%)$

- Tanah kuburan muslim, luas $\pm 0,05(0,37 \%)$

Sasaran pembangunan yang ingin dicapai adalah penataan wilayah kumuh.

Tabel 32. Status dan Pemilikan Tanah lokasi Konsolidasi Tanah

\begin{tabular}{|l|l|c|c|c|}
\hline No. & Status Tanah & Luas (ha) & Jlh bidang & Jlh Pemilik/Penggarap \\
\hline 1. & Tanah Negara & 13,43 & 35 & 35 \\
\hline 2. & a. Hak Milik Adat & - & - & - \\
\hline & b.Hak Pakai (PLN) & 0,02 & 1 & \\
\hline
\end{tabular}

Sumber : BPN Kota Banjarmasin

\section{2) Vertikal}

Sampai saat ini belum pernah dilaksanakan Konsolidasi tanah Vertikal di Kota Banjarmasin.Walaupun demikian Pemerintah Kota sudah merencanakan untuk melaksanakan Konsolidasi tanah vertikal di daerah padat namun terbengkalai karena tidak ada dasar hukum pelaksanaannya, lokasinya berada di daerah Belasung Kelurahan Kertak baru Ulu dan disamping hotel Swiss Bell, gudang milik Pemerintah Kota yang diduduki oleh masyarakat.

Yang sudah dilaksanakan adalah proyek pembangunan 1000 tower. Dasar hukum pelaksanaannya adalah Perda Nomor 2 Tahun 2009 tentang Pengelolaan Rumah Susun Sederhana Sewa. Kendala yang cukup besar apabila di bangun rumah susun terutama karena lokasi tanahnya sebagian besar adalah tanah gambut yang memerlukan biaya cukup besar untuk 
pembangunan secara vertikal, dimana untuk pengurukannya saja sudah memakan biaya yang tidak sedikit ditambah lagi konstruksi tanah yang relatif tidak kuat untuk menyokong bangunan lebih dari empat lantai tersebut. Kendala yang lain adalah terlihat dari culture masyarakat Banjar sendiri yang lebih memilih untuk tinggal di rumah yang memiliki luas pekarangan yang besar

Untuk mengatasi kekumuhan dan menghindari pemukiman liar, pemerintah melalui Dinas Tata Kota Banjarmasin menyediakan rumah susun sederhana dengan sistem sewa (rusunawa)yang tersebar di beberapa lokasi antara lain :

- di Kelurahan Kelayan Selatan Kecamatan Banjarmasin Selatan, di mana lokasi semula adalah bekas lokalisasi kemudian ditutup oleh Pemkot yang diberikan bantuan dana oleh Departemen PU lalu diteruskan ke Ditjen Cipta Karya baru ada 2 twin blok asetnya belum diberikan ke Pemda tetapi sampai saat ini pengelolaannya ke Pemda sedangkan yang satu twin blok lagi direncanakan akan dibangun tahun ini (tanah Pemda dibangun oleh Cipta Karya) lima lantai. Lantai bawah diperuntukkan sebagai sarana umum seperti TPA dan kantor pengelola serta dijadikan sebagai tempat usaha. Mengenai sewa kontraknya hanya berlaku selama tiga tahun dan setelahnya dapat diperpanjang hanya satu kali saja.

- Rusunawa Ganda Maghfirah memiliki satu tower yang berisi 96 kamar. Khusus untuk lantai dasar digunakan sebagai ruang terbuka dan kantor. Hanya lantai dua sampai lima yang disewakan, masing-masing kamar memiliki luas 3x7 meter (type 21), idealnya maksimum dihuni oleh 4 orang dalam satu keluarga. Harga sewa Rusunawa tersebut terbilang murah sebesar Rp. 150.000 s/d Rp. 180.000.

Gambar 19. Rusunawa Ganda Maghfirah di Kota Banjarmasin
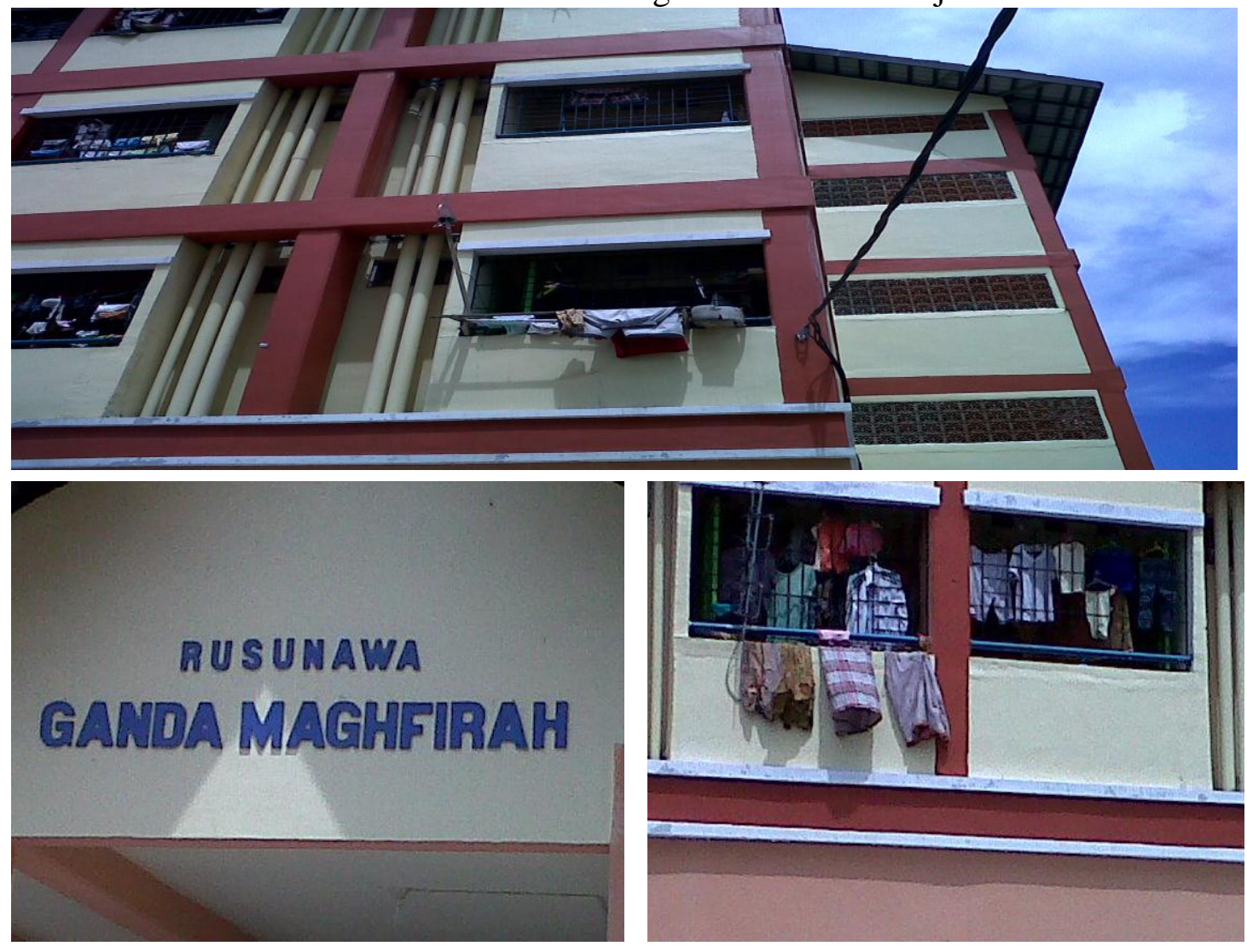
- Rusunawa milik Pemprov Kalimantan Selatan di Kelurahan Pekapuran Kecamatan Banjarmasin Selatan yang dibangun dengan dana APBD diperuntukan khusus bagi PNS golongan I dan II berjumlah 2 twin block masing-masing tiga lantai. Sementara itu di daerah Rawasari Jalan Jafri Zam-Zam Kelurahan Teluk Dalam terdapat perumahan kumuh yang akan direncanakan untuk dikonsolidasi. Keseluruhan rumah susun tersebut diperuntukan bagi masyarakat yang berpenghasilan relatif rendah.

- Perencanaan pembangunan Rusunawa lainnya di kawasan Bong Cina dahulu bekas tanah kuburan yang dihuni oleh masyarakat dimana tanah tersebut merupakan tanah Pemkot dalam jangka waktu dekat akan dibangun Rusunawa Pengambangan sebagai lokasi Ruang Terbuka Hijau (RTH). Selain itu masih ada kawasan lain yang peruntukannya tidak sesuai dengan kondisinya yaitu Pasar Batuah yang seharusnya digunakan sebagai tempat berjualan juga dimanfaatkan sebagian untuk tempat tinggal sehingga terkesan kumuh.

\section{B. PENGOLAHAN DATA}

\section{Gambaran Kepadatan Penduduk dan Pendapatan Perkapita di Lokasi Sampel Penelitian .}

Tabel 33. Gambaran Kepadatan Penduduk dan Pendapatan Perkapita di Lokasi Sampel Penelitian .

\begin{tabular}{|r|l|r|r|r|}
\hline No & \multicolumn{1}{|c|}{ Provinsi } & $\begin{array}{c}\text { Luas Wilayah } \\
\text { (ha) }\end{array}$ & $\begin{array}{c}\text { Jumlah } \\
\text { Penduduk } \\
\text { (Jiwa) }\end{array}$ & \multicolumn{1}{|c|}{$\begin{array}{c}\text { Kepadatan } \\
\text { (Jiwa/Km2) }\end{array}$} \\
\hline 1 & Sumatera Utara & 71.861 & 12.985 .075 & 181 \\
\hline 2 & Sumatera Selatan & 113.339 & 7.446 .401 & 66 \\
\hline 3 & Jawa Barat & 37.101 & 43.021 .826 & 995 \\
\hline 4 & Jawa Tengah & 32.548 & 32.380 .687 & 795 \\
\hline 5 & Jawa Timur & 47.155 & 37.476 .011 & 1.084 \\
\hline 6 & DI. Yogyakarta & 3.186 & 3.452 .390 & 98 \\
\hline 7 & Kalimantan Selatan & 36.985 & 3.626 .119 & 129 \\
\hline 8 & Sulawesi Selatan & 62.483 & 8.032 .551 & \\
\hline
\end{tabular}

Sumber: BPS 2010, diolah 
Gambar 20. Grafik Kepadatan Penduduk di Lokasi Sampel Penelitian .

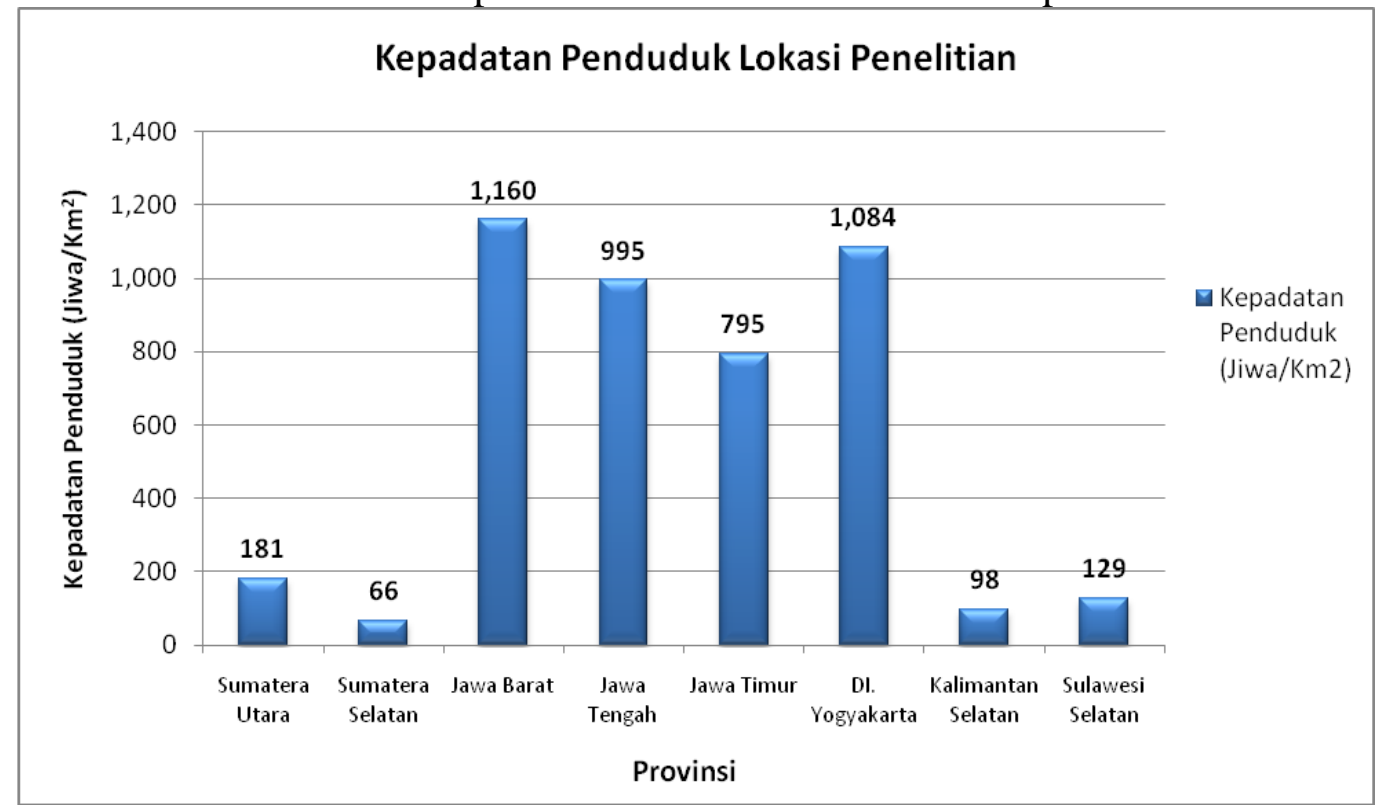

Gambaran kepadatan penduduk di lokasi penelitian dalam table dan grafik di atas menunjukkan bahwa Jawa Barat merupakan provinsi terpadat yaitu 1.160 Jiwa/Km2, kemudian disusul DI Yogyakarta yaitu $1.084 \mathrm{Jiwa} / \mathrm{Km} 2$, kemudian wilayah yang cukup padat yaitu Jawa Tengah dengan kepadatan penduduk 995 Jiwa/Km2, dan Jawa Timur dengan kepadatan penduduk sebesar 795 Jiwa/Km2, selanjutnya diikuti Sumatera Utara 181 Jiwa/Km2, Sulawesi Selatan 129 Jiwa/Km2, Kalimantan Selatan 98 jiwa/Km2 dan terakhir Sumatera Selatan 66 jiwa/Km2.

Tabel 34. Gambaran Kepadatan Penduduk dan Pendapatan Perkapita di Kota Sampel Penelitian.

\begin{tabular}{|c|l|r|r|r|}
\hline No & $\begin{array}{c}\text { Sampel Penelitian } \\
\text { Kota }\end{array}$ & $\begin{array}{c}\text { Luas Wilayah } \\
(\mathrm{Km} 2)\end{array}$ & $\begin{array}{c}\text { Jumlah Penduduk } \\
\text { (Jiwa) }\end{array}$ & $\begin{array}{c}\text { Kepadatan } \\
\text { (Jiwa/Km2) }\end{array}$ \\
\hline 1 & Medan & 265 & 2.109 .339 & 7,957 \\
\hline 2 & Palembang & 370 & 1.438 .938 & 3,885 \\
\hline 3 & Bandung & 167 & 2.417 .584 & 14,451 \\
\hline 4 & Semarang & 374 & 1.553 .778 & 4,158 \\
\hline 5 & Surabaya & 326 & 2.765 .908 & 8,475 \\
\hline 6 & Yogyakarta & 32.50 & 388.088 & 11,941 \\
\hline 7 & Banjarmasin & 72 & 625.395 & 8,686 \\
\hline 8 & Makassar & 176 & 1.339 .374 & 7,620 \\
\hline
\end{tabular}

Sumber: BPS 2010, diolah 
Gambar 21. Grafik Kepadatan Penduduk di Kota Sampel Penelitian .

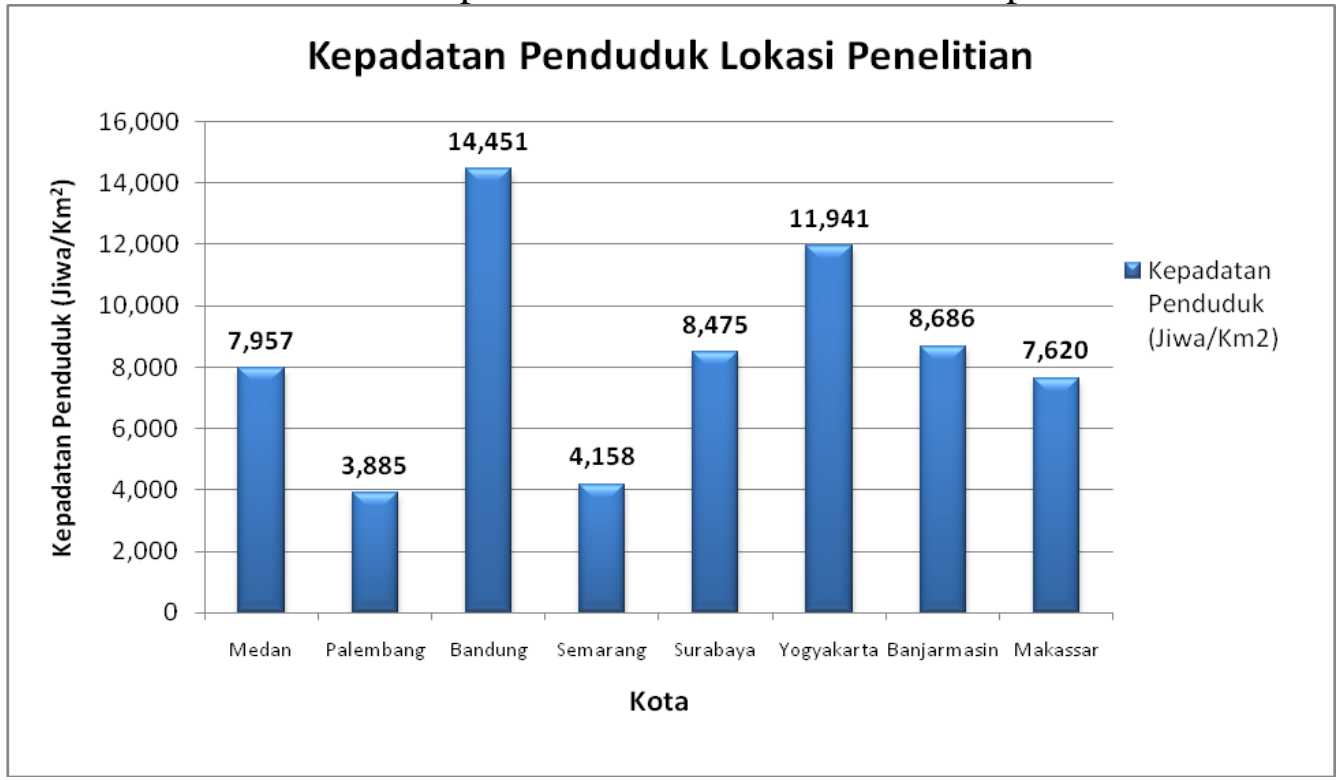

Gambaran kepadatan penduduk di Kota Sampel Penelitian dalam table dan grafik di atas menunjukkan bahwa Kota Bandung merupakan kota terpadat yaitu $14.451 \mathrm{Jiwa} / \mathrm{Km} 2$, kemudian disusul Kota Yogyakarta yaitu $11.941 \mathrm{Jiwa} / \mathrm{Km} 2$, kemudian kota yang cukup padat yaitu Banjarmasin dengan kepadatan penduduk $8.686 \mathrm{Jiwa} / \mathrm{Km} 2$, dan Surabaya dengan kepadatan penduduk sebesar 8.475 Jiwa/Km2, selanjutnya diikuti Medan 7.957 Jiwa/Km2, Makasar 7.620 Jiwa/Km2, Semarang 4.158 jiwa/Km2 dan terakhir Palembang 3.885 jiwa/Km2.

Wilayah yang terpadat di Kota Bandung adalah Wilayah yang terpadat di Kota Yogyakarta berada di wilayah kecamatan Gondomanan, kedua adalah wilayah kecamatan Wirobrajan, dan ketiga adalah kecamatan Gondokusuman.

\section{PDRB Perkapita dan Pertumbuhan Ekonomi di Lokasi Sampel Penelitian.}

Tabel 35. PDRB Perkapita dan Pertumbuhan Ekonomi di Lokasi Sampel Penelitian.

\begin{tabular}{|c|l|c|c|}
\hline No & \multicolumn{1}{|c|}{ Provinsi } & $\begin{array}{c}\text { Pendapatan } \\
\text { Per Kapita Tahun 2008 } \\
\text { (Juta Rp) }\end{array}$ & $\begin{array}{c}\text { Pertumb. } \\
\text { Ekonomi (\%) }\end{array}$ \\
\hline 1 & Sumatera Utara & 16,40 & 6,39 \\
\hline 2 & Sumatera Selatan & 18,72 & 5,10 \\
\hline 3 & Jawa Barat & 14,72 & 5,83 \\
\hline 4 & Jawa Tengah & 11,18 & 5,46 \\
\hline 5 & Jawa Timur & 16,75 & 5,90 \\
\hline 6 & DI. Yogyakarta & 10,98 & 5,02 \\
\hline 7 & Kalimantan Selatan & 13,20 & 6,23 \\
\hline 8 & Sulawesi Selatan & 10,90 & 7,78 \\
\hline
\end{tabular}

Sumber: BPS 2008, diolah 
Gambar 22. Grafik PDRB Perkapita di Lokasi Sampel Penelitian .

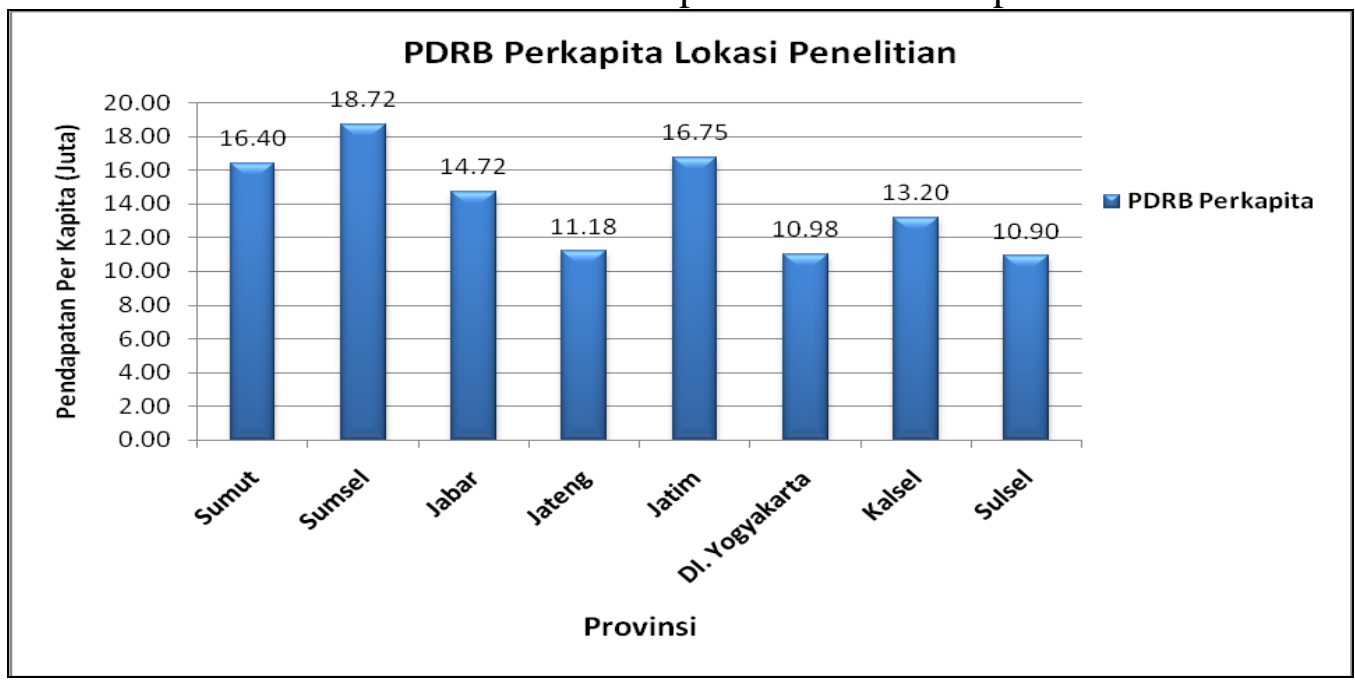

Gambar 23. Grafik Pertumbuhan Ekonomi di Lokasi Sampel Penelitian .

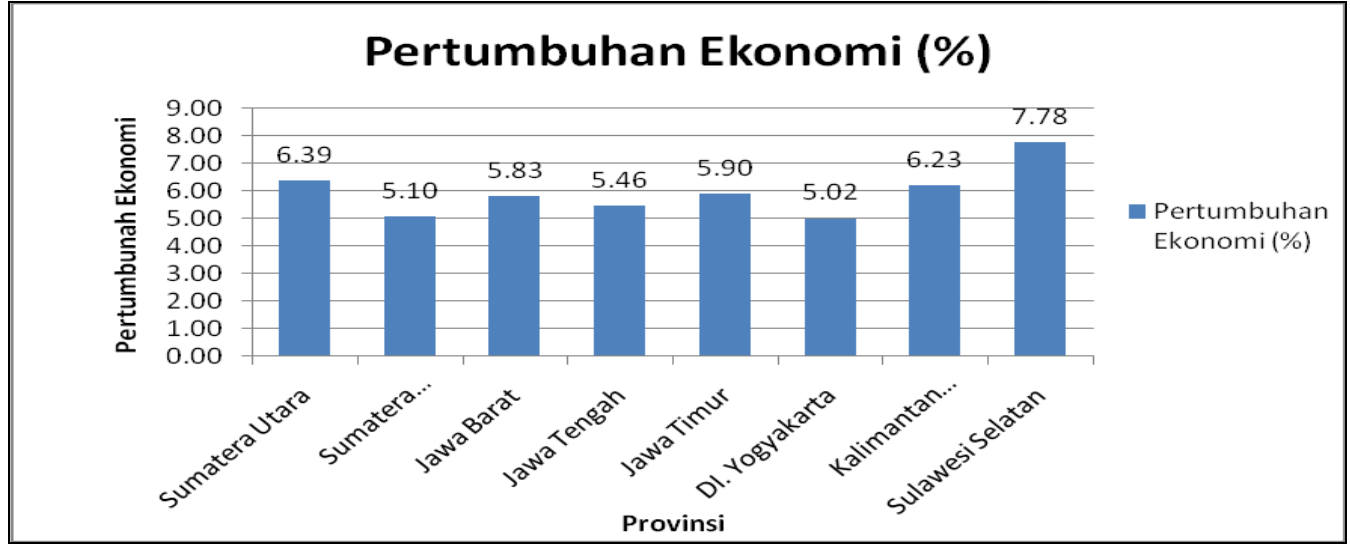

Gambaran pendapatan perkapita dan pertumbuhan ekonomi di lokasi penelitian dalam table dan grafik di atas menunjukkan bahwa Provinsi Sumatera Selatan mempunyai pendapatan perkapita tertinggi yaitu sebesar Rp.18,72 juta dan dengan laju pertumbuhan ekonomi sebesar 5,10\%, kemudian Jawa Timur dengan pendapatan perkapita sebesar Rp.16,75 juta dan dengan laju pertumbuhan ekonomi sebesar 5,90 \%, kemudian Sumatera Utara dengan pendapatan perkapita sebesar Rp.16,40 juta dan dengan laju pertumbuhan ekonomi sebesar 6,39 \%, selanjutnya Jawa Barat sebesar Rp.14,72 juta dengan pertumbuhan ekonomi 5,83\%, Kalimantan Selatan sebesar Rp.13,20 juta dengan pertumbuhan ekonomi 6,23 \%, Jawa Tengah sebesar Rp.11,18 juta dengan pertumbuhan ekonomi 5,46 \%, DI Yogyakarta sebesar Rp. 10,98 juta dengan pertumbuhan ekonomi 5,02 \%, dan Sulawesi Selatan sebesar Rp.10,90 juta dengan pertumbuhan ekonomi $7,78 \%$, 
Tabel 36. PDRB Perkapita dan Pertumbuhan Ekonomi di Kota Sampel Penelitian .

\begin{tabular}{|c|c|c|c|}
\hline No & $\begin{array}{c}\text { Sampel Penelitian } \\
\text { Kota }\end{array}$ & $\begin{array}{c}\text { Pendapatan } \\
\text { Per Kapita } \\
\text { (Juta Rp.) }\end{array}$ & $\begin{array}{c}\text { Pertumbuhan } \\
\text { Ekonomi (\%) }\end{array}$ \\
\hline 1 & Medan & 20,83 & 7,77 \\
\hline 2 & Palembang & 18,30 & 6,96 \\
\hline 3 & Bandung & 15,10 & 5,63 \\
\hline 4 & Semarang & 16,23 & 5,55 \\
\hline 5 & Surabaya & 34,77 & 6,35 \\
\hline 6 & Yogyakarta & 15,55 & 3,96 \\
\hline 7 & Banjarmasin & 8,47 & 3,68 \\
\hline 8 & Makassar & 13,09 & 8,09 \\
\hline
\end{tabular}

Sumber: BPS tahun 2005, diolah

Gambar 24. Grafik PDRB Perkapita di Lokasi Sampel Penelitian .

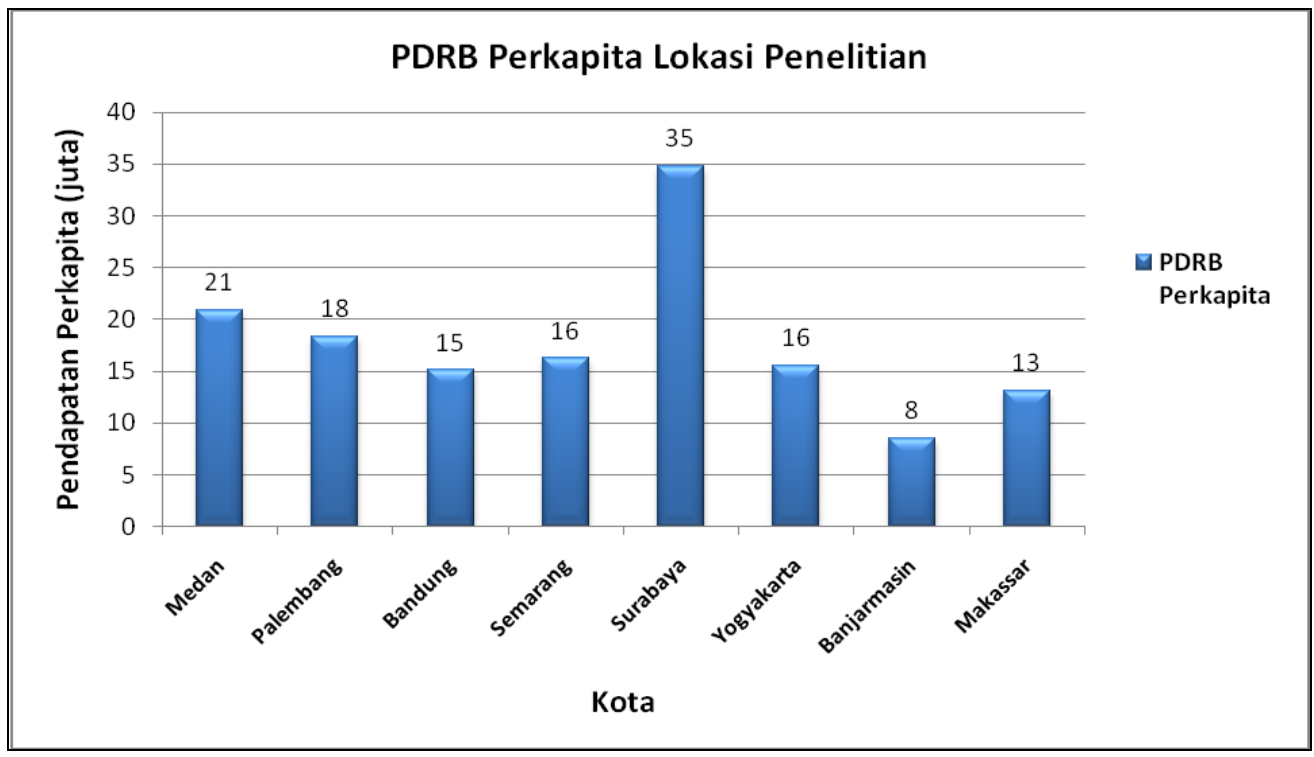

Pendapatan perkapita dan pertumbuhan ekonomi di sampel Kota penelitian dalam table dan grafik di atas menunjukkan bahwa tidak semua lokasi diperoleh data, pendapatan perkapita tertinggi yaitu di Kota Surabaya sebesar Rp.132,43 juta, kemudian Kota Medan dengan pendapatan perkapita sebesar Rp.34,26 juta dan Kota Makasar dengan pendapatan perkapita sebesar Rp.9,93 juta. 
Gambar 25. Grafik Pertumbuhan Ekonomi di Lokasi Sampel Penelitian.

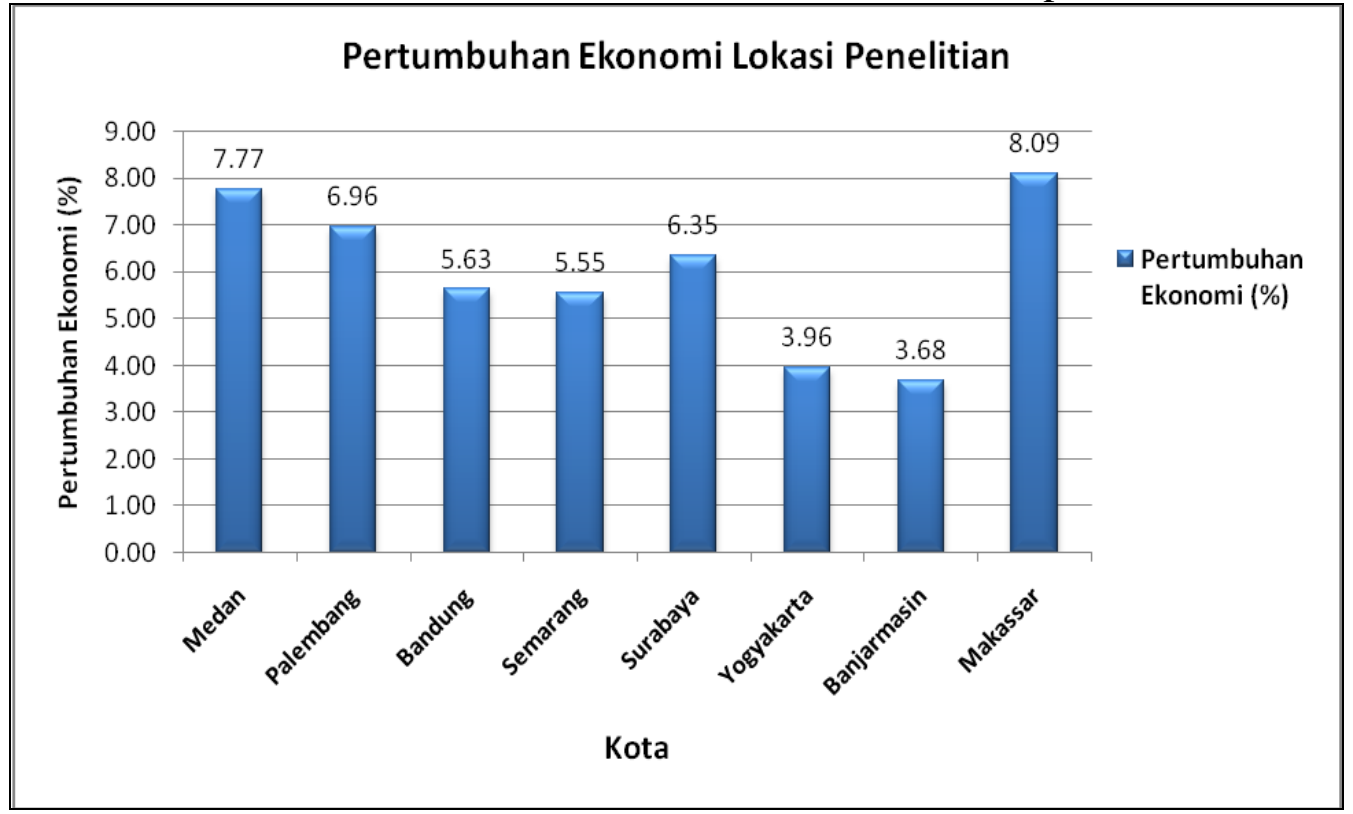

Pertumbuhan ekonomi di lokasi penelitian dalam table dan grafik di atas menunjukkan bahwa Pertumbuhan ekonomi tertinggi terdapat di Kota Makassar sebesar 8,09 \%, kemudian Kota Medan sebesar 7,77 \%, kemudian Palembang dengan laju pertumbuhan ekonomi sebesar 6,96 $\%$, dan seterusnya yang terkecil adalah di Kota Banjarmasin sebesar 3,68 \%.

\section{Status Tanah di Lokasi Sampel Penelitian.}

Tabel 37. Status Tanah di Lokasi Sampel Penelitian (dlm jumlah bidang).

\begin{tabular}{|c|c|c|c|c|c|c|c|}
\hline No. & Kota Sampel & Hak Milik & $\begin{array}{l}\text { Hak Guna } \\
\text { Bangunan }\end{array}$ & $\begin{array}{l}\text { Hak Guna } \\
\text { Usaha }\end{array}$ & $\begin{array}{l}\text { Hak } \\
\text { Pakai }\end{array}$ & $\begin{array}{c}\text { Hak } \\
\text { Pengelolaan }\end{array}$ & HMSRS \\
\hline 1 & Medan & 538.192 & 139.627 & 566 & 46.329 & 161 & 410 \\
\hline 2 & Palembang & 122.702 & 23.979 & 0 & 2.714 & 8 & 0 \\
\hline 3 & Bandung & 4.104 & 80.774 & 0 & 2.244 & 43 & 8.374 \\
\hline 4 & Semarang & - tad- & -tad- & -tad- & -tad- & -tad- & -tad- \\
\hline 5 & Surabaya & - tad- & -tad- & - tad- & -tad- & -tad- & - tad- \\
\hline 6 & Yogyakarta & 68.226 & 18.254 & 0 & 7.302 & 10 & 0 \\
\hline 7 & Banjarmasin & -tad- & -tad- & -tad- & -tad- & -tad- & $-\operatorname{tad}-$ \\
\hline 8 & Makasar & 8.555 & 44.196 & 0 & 2.362 & 62 & 6.931 \\
\hline 9 & Total & 673,553 & 306,830 & 566 & 60,951 & 284 & 15,715 \\
\hline
\end{tabular}

Sumber: BPN Kantor Pertanahan 2009, diolah 
Gambar 26. Grafik Status Tanah di Lokasi Sampel Penelitian (dlm jumlah bidang)

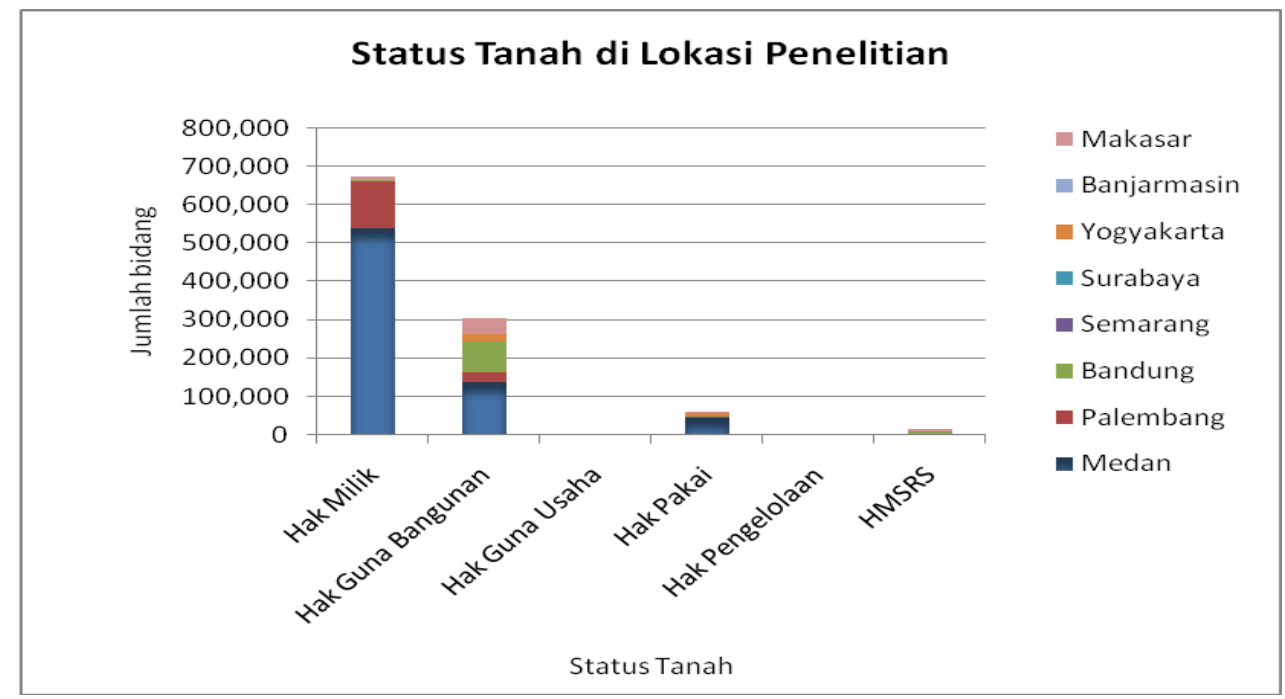

Status tanah di Lokasi Sampel Penelitian didominasi oleh Hak Milik, dan Gak Guna Bangunan dan sebagian kecil Hak Pakai, sedangkan Hak lainnya seperti Hak Guna Usaha, Hak Pengelolaan dan Hak Milik Atas Satuan Rumah Susun jumlahnya sedikit.

Status tanah di Kota Medan didominasi oleh Hak Milik sebanyak 538.192 bidang, kemudian Hak Guna Bangunan sebesar 139.627bidang, dan Hak Pakai sebanyak 46.329 bidang dan selebihnya Hak Guna Usaha sebanyak 566 bidang, HMSRS sebanyak 410 bidang dan Hak Pengelolaan sebanyak 161 bidang.

Status tanah di Kota Palembang didominasi oleh Hak Milik sebanyak 122.702 bidang, kemudian Hak Guna Bangunan sebesar 29.979bidang, dan Hak Pakai sebanyak 2.714 bidang dan selebihnya Hak Pengelolaan sebanyak 8 bidang.

Status tanah di Kota Bandung didominasi oleh Hak Guna Bangunan sebesar 80.774 bidang, kemudian HMSRS sebanyak 8.374 bidang, dan Hak Milik sebanyak 4.104 bidang, dan selebihnya Hak Pakai sebanyan 2.224 bidang dan Hak Pengelolaan sebanyak 43 bidang.

Status tanah di Kota Yogyakarta didominasi oleh Hak Milik sebanyak 68.226 bidang, kemudian Hak Guna Bangunan sebesar 18.254 bidang, dan Hak Pakai sebanyak 7.302 bidang dan selebihnya Hak Pengelolaan sebanyak 10 bidang.

Status tanah di Kota Makasar didominasi oleh Hak Guna Bangunan sebanyak 44.196 bidang, kemudian Hak Milik sebanyak 8.555 bidang, dan HMSRS sebanyak 6.931 bidang, Hak Pakai sebanyak 2.362 bidang, dan selebihnya Hak Pengelolaan sebanyak 62 bidang. 


\section{Penggunaan Tanah di Lokasi Sampel Penelitian.}

Tabel 38. Luas Penggunaan Tanah di Kota Sampel Penelitian

\begin{tabular}{|c|c|c|c|c|c|c|c|}
\hline No & $\begin{array}{l}\text { Kota } \\
\text { Sampel Penelitian } \\
\text { Tanah (ha) }\end{array}$ & Perumahan & Jasa & $\begin{array}{l}\text { Perusahaan } \\
\text { \& Industri }\end{array}$ & Pertanian & $\begin{array}{l}\text { Non Produktif, } \\
\text { Lahan Kosong \& } \\
\text { Lain-lain }\end{array}$ & Total \\
\hline \multirow[t]{2}{*}{1} & \multirow{2}{*}{$\begin{array}{l}\text { Medan } \\
(\%)\end{array}$} & $9,623.13$ & 503.69 & $1,511.07$ & $14,474.46$ & 477.18 & 26589.53 \\
\hline & & 36.19 & 1.89 & 5.68 & 54.44 & 1.79 & 100.00 \\
\hline \multirow[t]{2}{*}{2} & \multirow{2}{*}{$\begin{array}{l}\text { Palembang } \\
(\%)\end{array}$} & $12,011.00$ & 618.00 & $1,096.00$ & $14,457.00$ & 7198.00 & 35380.00 \\
\hline & & 33.95 & 1.75 & 3.10 & 40.86 & 20.34 & 100.00 \\
\hline \multirow[t]{2}{*}{3} & \multirow{2}{*}{$\begin{array}{l}\text { Bandung } \\
(\%)\end{array}$} & $9,479.00$ & $1,343.00$ & 803.88 & $3,278.56$ & 1825.56 & 16730.00 \\
\hline & & 56.66 & 8.03 & 4.81 & 19.60 & 10.91 & 100.00 \\
\hline \multirow[t]{2}{*}{4} & \multirow{2}{*}{$\begin{array}{l}\text { Semarang } \\
(\%)\end{array}$} & $12,592.68$ & 567.98 & $1,375.11$ & $18,369.62$ & 4461.62 & 37367.00 \\
\hline & & 33.70 & 1.52 & 3.68 & 49.16 & 11.94 & 100.00 \\
\hline \multirow[t]{2}{*}{5} & \multirow{2}{*}{$\begin{array}{l}\text { Surabaya } \\
(\%)\end{array}$} & $13,711.00$ & $2,962.06$ & $2,370.38$ & $10,297.80$ & 3276.51 & 32617.75 \\
\hline & & 42.04 & 9.08 & 7.27 & 31.57 & 10.05 & 100.00 \\
\hline \multirow[t]{2}{*}{6} & \multirow{2}{*}{$\begin{array}{l}\text { Yogyakarta } \\
(\%)\end{array}$} & $2,106.00$ & 275.56 & 329.80 & 130.03 & 408.201 & 3249.59 \\
\hline & & 64.81 & 8.48 & 10.15 & 4.00 & 12.56 & 100.00 \\
\hline \multirow[t]{2}{*}{7} & \multirow{2}{*}{$\begin{array}{l}\text { Banjarmasin } \\
(\%)\end{array}$} & 2426.40 & 109.44 & 264.96 & $3,539.52$ & 859.68 & 7200.00 \\
\hline & & 33.70 & 1.52 & 3.68 & 49.16 & 11.94 & 100.00 \\
\hline \multirow[t]{2}{*}{8} & \multirow{2}{*}{$\begin{array}{l}\text { Makassar } \\
(\%)\end{array}$} & $11,102.60$ & 0.00 & 957.10 & $2,230.90$ & 3286.40 & 17577.00 \\
\hline & & 63.17 & 0.00 & 5.45 & 12.69 & 18.70 & 100.00 \\
\hline 9 & Rata-rata (\%) & 45.53 & 4.03 & 5.48 & 32.69 & 12.28 & 100.00 \\
\hline
\end{tabular}

Sumber: BPN Kantor Pertanahan 2009, diolah

Gambar 27. Grafik Penggunaan Tanah di Lokasi Penelitian

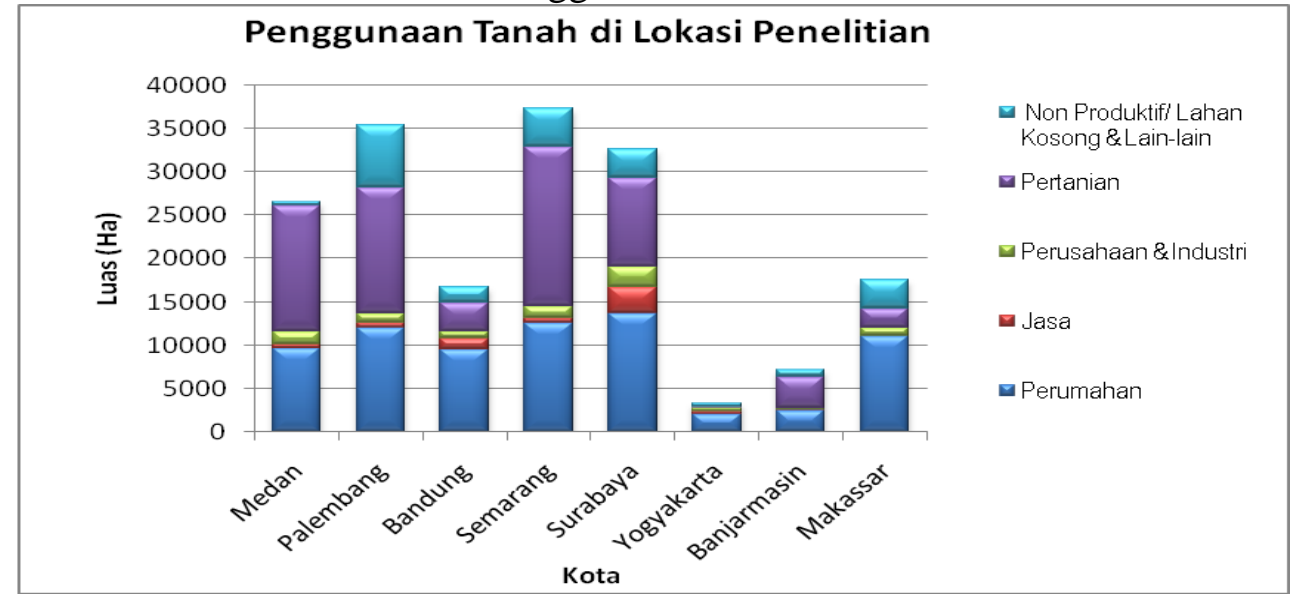

Penggunaan tanah di Lokasi Sampel Penelitian didominasi untuk penggunaan perumahan (rata-rata 45,53 \% luas wilayah kota) dan pertanian (rata-rata $32.69 \%$ luas wilayah kota), penggunaan tanah non produktif, lahan kosong dan lain-lain $12 \%$, perusahaan dan industry $5,48 \%$, dan jasa 4,03 \% (lihat table \& grafik). Penggunaan tanah untuk perumahan yang paling dominan di Kota Yogyakarta sebesar 64,81\%, kemudian di Kota Makasar sebesar 63,17\%, Kota Bandung sebesar 56,66\%, dan Kota Surabaya sebesar 42,04\%.Penggunaan tanah untuk pertanian yang paling dominan di Kota Medan sebesar 54,44\%, kemudian di Kota Semarang dan Kota Banjarmasin masing-masing sebesar 49,16\%, dan Kota Palembang sebesar 40,86\%. 
Penggunaan tanah non produktif, lahan kosong dan lain-lain yang paling dominan di Kota Palembang sebesar 20,34\%, kemudian di Kota Makasar sebesar 18,70\% dan di Kota Yogyakarta sebesar $12,56 \%$.

\section{Pelaksanaan Konsolidasi Tanah di Lokasi Sampel Penelitian.}

\section{a. Konsolidasi Tanah Horizontal}

Tabel 39. Pelaksanaan Konsolidasi Tanah Horizontal di Lokasi Sampel Penelitian

\begin{tabular}{|l|l|l|l|l|l|l|l|}
\hline No & \multicolumn{1}{|c|}{ Kota } & $\begin{array}{c}\text { Total } \\
\text { Lokasi }\end{array}$ & $\begin{array}{r}\text { Total } \\
\text { Luas } \\
\text { (ha) }\end{array}$ & $\begin{array}{c}\text { Jumlah } \\
\text { Bidang }\end{array}$ & \multicolumn{1}{|c|}{$\begin{array}{l}\text { Jumlah } \\
\text { Peserta }\end{array}$} & \multicolumn{1}{|c|}{ Tahun } & \multicolumn{1}{|c|}{ Keterangan } \\
\hline 1 & Medan & 2 & - & 418 & 418 & $\begin{array}{l}1990- \\
2010\end{array}$ & Untuk Perumahan, dana APBN \\
\hline 2 & Palembang & 1 & $4(\mathrm{ha})$ & - & 264 & 1999 & $\begin{array}{l}\text { Swadaya untuk perumahan \& } \\
\text { penyelesaian sengketa }\end{array}$ \\
\hline 3 & Bandung & 3 & 11.1547 & 155 & - & $\begin{array}{l}1986- \\
2005\end{array}$ & - \\
\hline 4 & Semarang & 5 & 6.1948 & 416 & - & 2009 & $\begin{array}{l}\text { Sumber dana APBN dan } \\
\text { Swadaya }\end{array}$ \\
\hline 5 & Surabaya & - & - & - & - & - & - \\
\hline 6 & Yogyakarta & - & - & - & - & - & - \\
\hline 7 & Banjarmasin & 1 & 13.45 & 36 & 35 & 2009 & APBN \\
\hline 8 & Makassar & 1 & $21789(\mathrm{ha})$ & 94 & 69 & 2001 & Sumber dana APBN \\
\hline
\end{tabular}

Sumber: BPN Kantor Pertanahan 2009, diolah

Pelaksanaan konsolidasi tanah yang dilaksanakan di Sampel Kota Penelitian, sebagian besar di laksanakan untuk perumahan dan dibiayai oleh Dipa BPN-RI yang bersumber dari APBN dan swadaya masyarakat melai PNBP .

Konsolidasi tanah adalah kebijakan pertanahan mengenai penataan kembali penguasaan dan penggunaan tanah yang bertujuan untuk meningkatkan kualitas lingkungan hidup/pemeliharaan sumber daya alam, untuk bisa dimanfaatkan dan digunakan secara optimal dengan melibatkan partisipasi masyarakat secara langsung.

Konsolidasi Tanah Perkotaan Kampung Teladan, Kelurahan Selabranti, Kec Seberang Ulu di Kota Palembang merupakan penyelesaian sengketa antara Yayasan Muhammaddiyah dengan masyarakat yang telah mengokupasi tanah tersebut sebagai tempat pemukman, melalui konsolidasi tanah perkotaan pada tahun 1999.

Konsolidasi Tanah Perkotaan di Kota Semarang pelaksanaannya sebagian besar merupakan pengkaplingan tanah untuk permukiman (rumah tinggal) yang semula dimiliki/dikuasai oleh beberapa orang saja kemudian dikapling untuk perumahan yang luasannya dengan memperhatikan ketentuan dalam Keputusan Gubernur KDH Tk. I Jawa Tengah No. 11/1998 tanggal 1-8-1998 tentang Pedoman Teknis Perencanaan Perpetakan dan Perda No. 11/2004 tanggal 1-8-2004 tentang Garis Sempadan.

Konsolidasi tanah perkotaan di Kota Makassar dilaksanakan oleh Kanwil BPN dan dibiayai oleh Dipa BPN-RI yang bersumber dari APBN dan swadaya masyarakat melalui PNBP. Konsolidasi tanah tersebut dilaksanakan di Desa Tamangamang, Kecamatan Manggala pada tahun 2001. Dengan luas 2,1789 ha sebanyak 94 bidang dengan peserta 94 orang. 


\section{b. Konsolidasi Tanah Vertikal}

Tabel 40. Pelaksanaan Konsolidasi Tanah dengan pendekatan pembangunan secara vertikal di Lokasi Sampel Penelitian

\begin{tabular}{|c|c|c|c|c|c|c|c|}
\hline No & Kota & Lokasi & Inisiator & Obyek & Subyek & Tahun & Keterangan \\
\hline 1 & Medan & $\begin{array}{l}\text { kampung Aur, } \\
\text { Kelurahan Aur, } \\
\text { Kecamatan } \\
\text { Medan Maimun }\end{array}$ & $\begin{array}{l}\text { Kementrian } \\
\text { Perumahan } \\
\text { Rakyat }\end{array}$ & $\begin{array}{l}\text { tanah grant sultan yang } \\
\text { dikuasai oleh } \\
\text { masyarakat selama } \\
\text { puluhan tahun daerah } \\
\text { kumuh dengan padat } \\
\text { penduduk }\end{array}$ & $\begin{array}{l}\text { masyarakat } \\
\text { setempat }\end{array}$ & 2009 & $\begin{array}{l}\text { tidak ditanggapi secara } \\
\text { positif oleh masyarakat } \\
\text { setempat, mereka lebih } \\
\text { memilih untuk diberikan } \\
\text { ganti rugi terhadap tanahnya }\end{array}$ \\
\hline \multirow[t]{2}{*}{2} & \multirow[t]{2}{*}{ Palembang } & $\begin{array}{l}\text { Simpang Sungki, } \\
\text { Kertapati }\end{array}$ & $\begin{array}{l}\text { Menpera dan } \\
\text { PT KAI }\end{array}$ & $\begin{array}{l}\text { tanah asset PT KAI } \\
\text { diduduki masyarakat } \\
\text { selama bertahun-tahun } \\
\text { dan saat ini sudah } \\
\text { merupakan pemukiman } \\
\text { padat }\end{array}$ & $\begin{array}{l}\text { masyarakat } \\
\text { setempat }\end{array}$ & 2009 & $\begin{array}{l}\text { Saat ini ditangani oleh } \\
\text { Menpera dan PT KAI Pusat } \\
\text { namun belum diperoleh } \\
\text { kesepakatan antara } \\
\text { masyarakat, PT KAI dan } \\
\text { Menpera }\end{array}$ \\
\hline & & $\begin{array}{l}\text { Rusun Milik } 24 \text { llir } \\
\text { Palembang dan } \\
26 \text { llir Palembang } \\
4 \text { lantai. }\end{array}$ & $\begin{array}{l}\text { Menpera dan } \\
\text { Pemerintah } \\
\text { Kota } \\
\text { Palembang }\end{array}$ & $\begin{array}{l}\text { Tanah nasyarakat } \\
\text { korban kebakaran yang } \\
\text { merupakan pemukiman } \\
\text { padat dan dihuni } \\
\text { melebihi kapasitas yang } \\
\text { menyebabkan } \\
\text { kekumuhan }\end{array}$ & $\begin{array}{l}\text { masyarakat } \\
\text { setempat }\end{array}$ & 1989 & $\begin{array}{l}\text { Pemkot Palembang } \\
\text { merencanakan peremajaan } \\
\text { Rusun yang semula } 4 \text { lantai, } \\
\text { menjadi } 12 \text { lantai, karena } \\
\text { kondisi bangunan sudah tua } \\
\text { dan kumuh. warga resah } \\
\text { takut kehilangan tempat } \\
\text { tinggal, dan kelangsungan } \\
\text { kehidupan keluarga yang } \\
\text { tidak mampu. }\end{array}$ \\
\hline 3 & Bandung & $\begin{array}{l}\text { Kelurahan } \\
\text { Cibabat, } \\
\text { Kecamatan } \\
\text { Cimahi Utara }\end{array}$ & $\begin{array}{l}\text { Pemerintah } \\
\text { Kota Cimahi }\end{array}$ & $\begin{array}{l}\text { tanah hak milik adat } \\
\text { merupakan daerah } \\
\text { kumuh dengan padat } \\
\text { penduduk }\end{array}$ & $\begin{array}{l}\text { masyarakat } \\
\text { setempat }\end{array}$ & 2009 & $\begin{array}{l}\text { Belum ada kesepakatan } \\
\text { terhadap pembagian tanah } \\
\text { setelah dilaksanakan } \\
\text { Konsolidasi Tanah }\end{array}$ \\
\hline 4 & Semarang & $\begin{array}{l}\text { Pekunden } \\
\text { Semarang } \\
\text { Tengah }\end{array}$ & $\begin{array}{l}\text { Pemerintah } \\
\text { Kota } \\
\text { Semarang }\end{array}$ & $\begin{array}{l}\text { Tanah pemda dan } \\
\text { masyarakat }\end{array}$ & $\begin{array}{l}\text { Masyarakat } \\
\text { setempat } \\
\text { dan Pemda }\end{array}$ & 1991 & $\begin{array}{l}50 \text { unit status hak milik, } \\
38 \text { unit status sewa ke } \\
\text { Pemkot. } \\
\text { Proses Sertifikat dari } 50 \\
\text { rumah sampai saat ini } \\
\text { belum selesai. }\end{array}$ \\
\hline \multirow[t]{2}{*}{5} & Surabaya & $\begin{array}{l}\text { Kp.Sumbo, } \\
\text { Kel.Simolawang } \\
\text { Kec. Simokerto }\end{array}$ & $\begin{array}{l}\text { Pemerintah } \\
\text { Kota } \\
\text { Surabaya } \\
\text { dan Johan } \\
\text { Silaas }\end{array}$ & Tanah Pemerintah Kota & $\begin{array}{l}\text { orang } \\
\text { madura } \\
\text { pengelola } \\
\text { kandang } \\
\text { sapi dan } \\
\text { pegawai } \\
\text { Dinas } \\
\text { Kebersihan }\end{array}$ & 1989 & $\begin{array}{l}\text { semula adalah kandang sapi } \\
\text { yang dikelola oleh orang } \\
\text { madura dan pegawai Dinas } \\
\text { Kebersihan } \\
\text { karena kumuh akhirnya } \\
\text { dibangun rusun dengan } \\
\text { prioritas orang-orang yang } \\
\text { semula menetap di daerah } \\
\text { tersebut }\end{array}$ \\
\hline & & Bangun rejo & $\begin{array}{l}\text { Pemerintah } \\
\text { Kota } \\
\text { Surabaya }\end{array}$ & Tanah Pemerintah Kota & $\begin{array}{l}\text { masyarakat } \\
\text { setempat }\end{array}$ & - & $\begin{array}{l}\text { kumuh akhirnya dibangun } \\
\text { rusun dengan prioritas yang } \\
\text { bertempat tinggal }\end{array}$ \\
\hline 6 & Yogyakarta & - & - & - & - & - & $\begin{array}{l}\text { konsolidasi tanah dengan } \\
\text { pendekatan pembangunan } \\
\text { perumahan secara vertikal } \\
\text { belum ada }\end{array}$ \\
\hline 7 & Banjarmasin & & & & & & \\
\hline 8 & Makassar & & & & & & \\
\hline
\end{tabular}

Sumber: BPN Kantor Pertanahan 2009, diolah 
Pengembangan konsep konsolidasi tanah dengan pendekatan pembangunan perumahan vertikal untuk menata kembali penguasaan, pemilikan, penggunaan dan pemanfaatan tanah di wilayah perkotaan :

\section{Kota Medan.}

Keinginan untuk melaksanakan Konsolidasi Tanah Perkotaan secara vertikal di Kota Medan yang diinisiasi oleh Kementrian Perumahan Rakyat pada tahun 2009 di kampung Aur, Kelurahan Aur, Kecamatan Medan Maimun, lokasinya merupakan daerah kumuh dengan padat penduduk namun tidak ditanggapi secara positif oleh masyarakat setempat, mereka lebih memilih untuk diberikan ganti rugi terhadap tanahnya. Tanah tersebut statusnya adalah tanah grant sultan yang sudah dikuasai oleh masyarakat selama puluhan tahun.

Menumbuhkan kesadaran kepada masyarakat untuk merelakan tanahnya agar dapat dijadikan obyek Konsolidasi tanah secara Vertikal tidaklah mudah, hal ini sudah coba dilakukan di Kelurahan Aur, Kecamatan Medan Maimun, Kota Medan, dimana lokasi perumahan tampak kumuh dengan jalan yang sempit, namun hal ini ditolak oleh masyarakat dengan berbagai alasan, antara lain :

- Kuatir jika terjadi gempa

- Harus menggunakan tangga sedangkan masyarakatnya banyak yang sudah tua

- Takut jika terjadi kebakaran

- Membahayakan anak-anak jika berada dibangunan bertingkat

Berbagai alasan tersebut di atas dapat dipahami mengingat masyarakat belum terbiasa untuk tinggal di perumahan secara vertikal. Untuk itu sosialisasi perlu gencar dilakukan untuk memberikan pemahaman yang lebih baik kepada masyarakat.

Sebagai sesuatu yang baru bagi masyarakat, cukup banyak permasalahan yang menyangkut pengelolaan rumah susun. Permasalahan penghunian datang dari kenyataan bahwa menghuni rumah susun masih dirasakan sebagai bentuk budaya baru yang memerlukan waktu penyesuaian. Rumah susun terdiri dari beberapa lantai hunian, merupakan bentuk perubahan hidup yang biasa melekat dengan tanah, menjadi tidak memiliki tanah untuk sekedar bercocok tanam. Kendala lain adalah masalah penghunian, pada awal penghunian sudah diadakan seleksi sesuai dengan target sasaran, yaitu masyarakat yang berpenghasilan rendah. Namun dalam perjalanannya, banyak penghuni yang memperjual-belikan hak penghuniannya kepada orangorang yang tidak berhak.

\section{Kota Palembang}

Konsolidasi Tanah Perkotaan dengan pendekatan pembangunan secara vertical direncanakan di lokasi Simpang Sungki, Kertapati, tanah ini merupakan asset PT KAI dekat dengan Setasiun Kereta Kertapati yang telah diduduki oleh masyarakat sebagai tempat pemukiman selama bertahun-tahun dan saat ini sudah merupakan daerah pemukiman padat. Direncanaakan akan ditata kembali dengan konsep konsolidasi vertikal namun belum diperoleh kesepakatan dari berbagai pihak terkait, dan saat ini ditangani oleh Menpera dan PT KAI Pusat namun belum diperoleh kesepakatan antara masyarakat, PT KAI dan Menpera.

Rusun Milik 24 dan 26 Ilir Palembang semula merupakan daerah pemukiman padat korban kebakaran yang dihuni oleh masyarakat dengan melebihi kapasitas yang menyebabkan 
kekumuhan. Menpera dan Pemerintah Kota Palembang tahun 1998 berinisiatif untuk membangun kawasan sersebut menjadi rumah susun milik untuk memenuhi kebutuhan masyarakat korban kebakaran dan masyarakat sekitarnya yang waktu itu cupup padat dan kumuh, diharapkan dapat ditampung dalam rumah susun tersebut.

Pembangunan rusun dibangun 4 lantai dan pelaksanaan pembangunannya diserahkan kepada Perum Perumnas. Proses pembangunan rusun dilaksanakan dengan tahapan pemberian ganti-rugi asset yang dimiliki oleh masyarakat korban kebakaran dan sekitarnya, dengan nilai kompensasi yang ditaksir oleh Panitia 9 (Panitia Pembebasan Tanah).

Masyarakat yang mendapatkan ganti-rugi tersebut diberikan prioritas untuk memperoleh kembali Rusun setelah dibangun dengan cara membeli baik secara chas maupun angsuran/kredit, namun tidak semua masyarakat yang mendapatkan ganti-rugi tersebut mengambil kembali rusun tersebut, karena sebagian membeli tanah atau rumah di lokasi lain bukan rumah susun;

Pembangunan rusun dibangun 4 lantai sebanyak 61 tower dengan berbagai type yaitu type 18 sebanyak 1634 unit, type 36 sebanyak 976 unit dan type 54 sebanyak 954 unit dengan jumlah 3564 unit.

Menurut Kabid Renstra Bappeda, Bpk. Gunawan dan tanggapan Direktur Perum Perumnas Kota Palembang Ir. Arif Sutopo, kebutuhan akan hunian layak bagi warga berpenghasilan menengah ke bawah di Kota Palembang sudah sangat mendesak, saat ini sedang merencanakan peremajaan Rumah Susun 24 dan 26 Ilir Palembang yang semula 4 lantai direncanakan ditingkatkan menjadi 12 lantai, karena bangunannya sudah tua dan kondisinya sudah kumuh, di samping itu juga merencanakan untuk membangun rusun di lokasi lainnya.

Pada saat ini sedang diupayakan penghutungan-penghitungan, identifikasi data hunian dan penghuni rusun, namun masyarakat penghuni sebagian besar sudah kurang percaya dan sebagian lagi sudah apatis terhadap kebijakan peremajaan tersebut, yang penting menurut mereka dapat memperoleh ganti rugi yang cukup dan memadai.

Pengembangan konsolidasi tanah vertical menurut Ketua DPU Kota Palembang maupun Kepala Perum Perumnas sangat dimungkinkan untuk dikembangkan di Kota Palembang, namun diperlukan perencanaan yang matang dan persetujuan dari pusat.

\section{Kota Bandung}

Konsolidasi Tanah Perkotaan dengan pendekatan pembangunan secara vertikal, pada tahun 2009 yang diinisiasi oleh Pemerintah Kota Cimahi di RW 18 , Kelurahan Cibabat, Kecamatan Cimahi Utara dimana lokasinya merupakan daerah kumuh dengan padat penduduk. Luas wilayah RW $18 \pm 65.505 \mathrm{M}^{2}$, dengan bidang tanah terkecil seluas $\pm 28 \mathrm{M}^{2}$, sebanyak 415 bidang. Tanah tersebut statusnya adalah tanah hak milik adat, NJOP terendah Rp. 40.000,- dan NJOP tertinggi Rp. 537.000,-- Namun pelaksanaan Konsolidasi Tanah Vertikal tersebut tidak dapat terlaksana, kemungkinan permasalahan di lapangan yaitu :

a. Nilai tanah sebelum dilaksanakan Konsolidasi Tanah dengan setelah dilaksanakan Konsolidasi Tanah;

b. Perubahan pola huni masyarakat horizontal ke vertikal;

c. Penanganan terhadap tempat tinggal sementara para peserta Konsolidasi Tanah selama dilaksanakan pembangunan;

d. Penanganan terhadap penduduk yang tidak bersedia ikut dalam kegiatan Konsolidasi Tanah; 
e. Belum ada kesepakatan terhadap pembagian tanah setelah dilaksanakan Konsolidasi Tanah;

f. Sumber anggaran untuk kegiatan Konsolidasi Tanah.

\section{Kota Semarang}

Konsolidasi tanah perkotaan di Propinsi Jawa Tengah dilaksanakan oleh Kanwil BPN dan dibiayai oleh Dipa BPN-RI yang bersumber dari APBN dan swadaya masyarakat melai PNBP . Konsolidasi tanah adalah kebijakan pertanahan mengenai penataan kembali penguasaan dan penggunaan tanah yang bertujuan untuk meningkatkan kualitas lingkungan hidup/ pemeliharaan sumber daya alam, untuk bisa dimanfaatkan dan digunakan secara optimal dengan melibatkan partisipasi masyarakat secara langsung.

Konsolidasi tanah bertujuan untuk memanfaatkan tanah secara optimal, seimbang, dan lestari dengan meningkatkan efisiensi pengunaan tanah dan pemanfaatannya, sehingga dengan konsolidasi tanah tersebut diharapkan dapat diambil manfaat antara lain sebagai berikut :

a. memenuhi kebutuhan akan adanya lingkungan yang teratur, tertib dan sehat;

b. meningkatkan hasil-hasil pembangunan pemukiman sehingga dapat dinikmati langsung oleh pemilik tanah;

c. mempercepat laju pembangunan wilayah permukiman;

d. menertibkan administrasi pertanahan serta menghemat pengeluaran dana Pemerintah untuk biaya pembangunan prasarana dan fasilitas umum;

e. meningkatkan efisiensi dan produktivitas penggunaan tanah.

Konsolidasi Tanah Perkotaan dengan pendekatan pembangunan secara vertical di Kota Semarang belum pernah dilaksanakan, namun pembangunan rumah susun sederhana (rusuna) sebagai upaya mempercepat pemenuhan kebutuhan perumahan bagi masyarakat perkotaan terutama yang berpenghasilan menengah bawah dan MBR dengan mengedepankan efisiensi penggunaan tanah sekaligus penataan permukiman di kawasan perkotaan telah dilaksanakan di beberapa lokasi sebagai berikut :

Tabel 41. Lokasi Pembangunan Rusun/Rusunawa di Kota Semarang, Propinsi Jawa Tengah

\begin{tabular}{|c|c|c|c|c|c|c|c|}
\hline No. & Nama & Lokasi & Type & $\begin{array}{l}\text { Jumlah } \\
\text { Unit }\end{array}$ & $\begin{array}{l}\text { Luas } \\
\text { Bangunan }\end{array}$ & $\begin{array}{l}\text { Luas } \\
\text { Tanah }\end{array}$ & Keterangan \\
\hline 1 & $\begin{array}{l}\text { Rusun Plamomgansari } \\
\text { Blok A-K, 2lt }\end{array}$ & $\begin{array}{l}\text { Plamongansari } \\
\text { Pedurungan }\end{array}$ & 27 & 208 & 5618 & 9800 & Sewa \\
\hline 2 & $\begin{array}{l}\text { Rusun Karangroto Blok A } \\
\text { 26, B } 24 \text { Unit }\end{array}$ & Karangroto, Genuk & 27 & 50 & 1999 & 3250 & Sewa \\
\hline 3 & $\begin{array}{l}\text { Rusun Karangroto Blok C, } \\
2 \text { Unit, } 2 \text { It }\end{array}$ & Karangroto, Genuk & 27 & 104 & 1993 & 2808 & Sewa \\
\hline 4 & Rusun Gayamsari 1 Blok & $\begin{array}{l}\text { Tlogomulyo } \\
\text { Pedurungan }\end{array}$ & 27 & 20 & 540 & 1200 & Sewa \\
\hline 5 & $\begin{array}{l}\text { Rusun Bandarharjo I } \\
1 \text { blok } 4 \text { lantai }\end{array}$ & $\begin{array}{l}\text { Bandarharjo } \\
\text { Semarang Utara }\end{array}$ & $\begin{array}{r}2736 \\
54\end{array}$ & 30 & 1008 & 779 & Sewa \\
\hline 6 & $\begin{array}{l}\text { Rusun Bandarharjo I } \\
1 \text { blok } 4 \text { lantai }\end{array}$ & $\begin{array}{l}\text { Bandarharjo } \\
\text { Semarang Utara }\end{array}$ & 2736 & 180 & 5184 & 3774 & Sewa \\
\hline 7 & $\begin{array}{l}\text { Rusun Pekunden } 5 \text { blok } \\
4 \text { lantai }\end{array}$ & $\begin{array}{l}\text { Pekunden } \\
\text { Semarang Tengah }\end{array}$ & $\begin{array}{r}2754 \\
81 \\
\end{array}$ & 118 & & & $\begin{array}{c}\text { Rusun milik } \\
\text { dan sewa }\end{array}$ \\
\hline 8 & Pondok Boro Trimulyo & Trimilyo, Genuk & 18 & 12 & 216 & 1329 & sewa \\
\hline 9 & $\begin{array}{l}\text { Rusun Kaligawe, } \\
\text { Sawahbesar, Kec. Gayan } \\
\text { Sari } 1989\end{array}$ & $\begin{array}{l}\text { Kaligawe, } \\
\text { Sawahbesar, Kec. } \\
\text { Gayam Sari }\end{array}$ & 2427 & 672 & 21000 & & $\begin{array}{l}\text { Ex bengkok, } \\
\text { milik Pemda }\end{array}$ \\
\hline
\end{tabular}

Sumber : Pengolahan data Kota Semarang 2010 
Rusun Kaligawe, Sawahbesar, Kec. Gayan Sari (sejak 1989) akan diperuntukkan 672 KK terutama bagi warga Tambakan yang terkena Proyek Waduk Jatibarang, 264 orang dan warga yang terkena program pengembangan jalan arteri utara (Semarang Nort Ringroad) 30 orang untuk masyarakat umum dengan proses seleksi.

\section{Rusun Pekunden, Semarang Tengah, Kota Semarang :}

Pembangunan Rusun Pekunden merupakan Pelaksanaan Program Penataan Permukiman di tengah perkotaan Pemerintah Kota Semarang membangun Rumah Susun Pekunden pada tahun 1991 yang lokasinya di belakang Balai Kota Semarang dengan Sistim "Membangun Tanpa Menggusur" karena penghuninya adalah warga pemilik rumah yang terkena proyek.

Pembangunan Rusun Pekunden, dimaksudkan untuk menata kembali permukiman yang sudah ada tetapi tidak layak huni ditengah perkotaan dan mayoritas penghuninya warga ekonomi lemah.Pembangunan rusun diawali dengan kesepakatan Pemkot dengan masyarakat penghuni dengan perjanjian bahwa tanah dan bangunan masyarakat yang berdomisili di lingkungan tersebut dinilai sesuai dengan kondisi existing yang ada. Masing-masing diberikan kompensasi sesuai dengan nilai tanah dan bangunan tersebut, namun tidak diberikaan dalam bentuk uang tetapi sebagai uang muka untuk mendapatkan unit satuan atas rumah susun yang akan dibangun sesuai proporsi nilai tanah yang sudah disepakati oleh seluruh penghuni yang ada.

Hal ini diharapkan dapat meningkatkan kesejahteraan para penghuni yang sebagian besar adalah karyawan/buruh industri, sehingga mendapatkan keuntungan antara lain :

1. Warga tidak perlu mencari tempat tinggal pengganti dengan lingkungan yang masih sama

2. Dapat menikmati rumah yang layak di perkotaan sesuai dengan peghasilannya.

3. Dapat menikmati lingkungan yang dilengkapi dengan taman,;tempat bermain anak, lapangan olah raga, balai serbaguna yang dipergunakan bersama,

4. Dapat mengembangkan usaha karena di lantai dasar disiapkan untuk tempat usaha

5. Hemat biaya transportasi, dekat dengan tempat kerja.

6. Hemat waktu di perjalanan sehingga dapat meningkatkan produktivitas.

7. Dapat hidup sehat karena tiap rumah dilengkapi dengan $\mathrm{KM} / \mathrm{WC}$, dapur dan tempat jemuran sendiri walaupun type 27.

Hal ini sejalan dengan program Pemda dalam Peremajaan Pemukiman di perkotaan serta Memasyarakatkan Rumah Susun dalam Pemilihan Pemukiman di perkotaan.

Pelaksanaan Pembangunan Rusun Pekunden :

1. Dasar pelaksanaan adalah PP NO. 5/1990 tentang peremajaan permukinan kumuh ditengah perkotaan, terutama tanah milik negara;

2. Lokasi Rusun Pekunden adalah wilayah Rt 04 dan Rt 05/Rw I Kelurahan Pekunden Kecamatan Semarang Timur (sebelum ada penataan kota);

3. Terdiri dari: 29 bangunan rumah penduduk dan 1 bangunan Musholla Al Mukhsin, yang ditenpati oleh $74 \mathrm{KK}$;

4. Survey bulan april 1991 oleh mahasiswa UNDIP yang didampingi oleh Ir.Panggardjito dari PU Cipta Karya Semarang; 
5. Penyuluhan warga oleh ketua BAPPEDA Semarang;

6. Usulan warga kepada Tim Satgas Rusun Pekunden :

- Pelaksanaan pembangunan Rusun secara manusiawi/melalui pendekatan;

- Mernbangun tanpa menggusur artinya warga mendapat prioritas utama untuk menghuni rusun;

- Bangunan tidak membuat suasana kumuh baru ada kamar mandi/wc tiap rumah, tempat jemuran dan fasilitas umum yang memadai;

- Sistem tidak merugikan warga masyarakat penghuni;

- Harga sewa rusun terjangkau sesuai kemampuan;

- Selama pembangunan warga tidak diterlantarkan dan diberi biaya pondokan;

- Sarusun yang sudah lunas dapat sertifikat sarusun.

7. Kesepakatan warga penghuni dengan Pem. Kodya Semarang tanggal 21-8-1991 :

a) Sebelum rumah dibongkar warga mendapatkan kompensasi sesuai dengan aset yang dimiliki, tetapi untuk membayar uang muka rusun yang akan ditempati;

b) Sebelum membongkar rumah, warga mendapat uang kontrak setahun dan biaya bongkar rumah .

c) Pembagian sarusun diserahkan kepada warga melalui wakil yang ditunjuk (Ny. Suatni).

d) Lantai I untuk usaha, lantai II dan III untuk pemilik rumah lama dan lantai IV untuk pengikut / penyewa / pendatang

e) Harga sarusun tiap Unit Rp 6.000.000,- ( enam juta rupiah) Type 27 ( 7,5x3,5m² = $27 \mathrm{~m}^{2}$ ) karena mendapat subsidi yang harga aslinya tiap unit $\mathrm{Rp} 9.000 .000$,- (pada tanun 1992)

- $\quad$ untuk type 54 harga Rp 12.000.000,-

- $\quad$ untuk type 81 harga Rp 18.000.000,-

8. Peletakan batu pertama pembangunan Rusun Pekunden tanggal 19-9-1991 oleh Walikota Soetrisno Suharto dengan penyerahan uang pondokan secara simbolis kepada 3 wakil warga ( Ny.Suatni, Ny.Wagiyem dan Bp.Ashari) .

9. Tanggal 23-3-1992 wakil warga mendapat panggilan untuk menerima penjelasan dari Asisten I Pemda Bp.Drs.Mugiyono. Bahwa rusun.Pekunden dibangun 5 Blok A,B,C,D.E terdiri dari 108 Unit yang dibuat menjadi 88 ruman rneliputi :

- $\quad$ Type $24=73$ unit sarusun

- $\quad$ Type $54=10$ unit sarusun

- $\quad$ Type $81=5$ unit sarusun

Jumlah $=88$ unit sarusun

10. Tanggal 77-9-1992, pembagian kunci rusun oleh Ny.Suatni;

11. Tanggal 19-140-1992, Penjelasan mengenai cicilan rumah tipe 27 tiap bulan Rp.40.000,/ bila harian Rp.1.350,- harga per unit tipe $27=$ Rp. 6.000.000,-

12. Tanggal 24-10-1992 Peresmian Rusun Pekunden.

13. Tanggal 27-10-1992 membentuk pengurus Paguyuban Perkampungan Rumah Susun Pekunden disingkat PPRSP

14. Tempat Usaha di Blok A dan E dibangun tahun 1995 dan Pasar Krempyeng dibangun tahun 1997. Kios di blok A dan F sistem sewa ke Pemkot, Pasar Krempyeng dikelola oleh Paguyuban. 
Kondisi Rusun Pekunden :

- Wilayah

- Kelurahan

: RT 04,05,06/RW I

- Kecamatan

: Pekunden

- Kota

: Semarang Tengah

- Luas Lahan

: Semarang

- Luas Bangunan

: $\pm 5000 \mathrm{~m}^{2}$

- Jumlah Blok

: $\pm 3888 \mathrm{~m}^{2}$

- Jumlah Lantai

: 5 (A,B.C,D,E)

- Jumlah Unit

$: 4$

- Jumlah Kios

: 88 sarusun

- Jumlah Pujasera

: 28 (Block A dan E)

- Jumlah Kios Besar : 4 (Lantai Dasar Block B)

- Jumiah Pompa Artetis : 4

- Jumlah Pompa block : 1

Status Penghuni Rusun Pekunden :

- 50 rumah status hak milik, sudah bayar uang muka melalui uang kompensasi nilai aset yang dimiliki semula;

- 38 rumah status sewa yang besarnya Rp. 13.500,- s/d Rp.15.000,- setiap bulan langsung ke Pemkot.

- Proses Sertifikat dari 50 rumah sampai saat ini belum selesai.

Pengelolaan Rusun Pekunden :

Pengelolaan Rusun Pekunden sangat sederhana, karena dikelola langsung oleh penghuni Paguyuban Perkampungan Rumah Susun Pekunden ( PPRSP ).

E. Sumber Dana :

7. luran warga tiap bulan $=88 \times$ Rp. $13.000,-=$ Rp. 1.144 .000

8. Hasil retribusi pasar krempyeng $\quad=\mathrm{Rp} .300 .000$

9. Hasil pengelolaan wc umum = Rp. 150.000

10. Hasil pengelolaan air PDAM $\quad=$ Rp. 200.000

11. Hasil parkir sepeda motor di aula $\quad=$ Rp. 125.000

12. Hasil iuran Lt dasar

$=\underline{\text { Rp. } \quad 146.000}$

Rp.2.065.000

F. Biaya Operasional Sebulan :

10. Rekening listrik pompa dan umum

11. Rekening air ledeng PDAM

$=$ Rp. $\quad 800.000$

12. Honor petugas air bersih

$=$ Rp. $\quad 125.000$

$=$ Rp. $\quad 250.000$

13. Honor petugas pasar dan warung air $\quad=\mathrm{Rp} . \quad 100.000$

14. Honor penyapu / pengangkut sampah $\quad=\mathrm{Rp} . \quad 150.000$

15. Honor petugas parkir

= Rp. $\quad 50.000$ 
$\begin{array}{lll}\text { 16. Bayar sewa Bl } / 1,2,3 \text {, tiap bulan } & =\mathrm{Rp} . & 120.000 \\ \text { 17. Konsumsi rapat pengurus } & =\mathrm{Rp} . & 25.000 \\ \text { 18. Dana perbaikan dan tak terduga } & =\mathrm{Rp} . & 445.000 \\ & \text { Rp. } & 2.065 .000\end{array}$

G. Sumber Dana Lain

4. Aula Rusun Pekunden disewakan untuk warga yang punya kerja/hajat mantu.

5. Menyewakan meja dan kursi yang ada di aula

6. Kios lantai Dasar Block Bl/1,2 dan 3 yang disewakan kepada yang membutuhkan sistem kontrak tahunan.

H. Catatan

5. Pengurus PPRSP yang mengelola Rusun sejak tahun 1992 s/d sekarang belum pernah mendapatkan honor, hanya dianggap pengabdian

6. Uang sewa Rusun dan Kios lantai Dasar di setor langsung ke Pemkot

7. Bila terjadi kerusakan pompa air atau bangunan rusun yang membutuhkan biaya besar, disamping iuran warga Pengurus mencari pinjaman yang pengembaliannya dianggsur bulanan

8. Untuk biaya pengecatan pagar besi pengaman dari lantai II,III,IV serta mengecat tembok yang.terjangkau, biaya dari iuran semua warga.

Upaya yang akan dilaksanakan :

1. Rencana akan menaikkan iuran warga untuk memberikan Honor kepada Pengurus PPRSP agar cara kerjanya optimal atau cari dana lain.

Saat ini karena tidak ada honor untuk Pengurus, yang mau aktif hanya $30 \%$ dari Pengurus yang ada, hanya Petugas oprasional yang mendapat honor.

2. Pendataan kembali pemilik dan penyewa karena sudah banyak yang beralih tangan tanpa setahu PPRSP .

3. Penertiban pemakaian tempat usaha yang sudah banyak yang beralih fungsi menjadi tempat tinggal sehingga lingkungan menjadi kumuh kembali .

4. Mendesak Dinas Tata Kota dan Pemukiman untuk secepatnya menyelesaikan proses sertifikat Rjsun agar kepemilikan sarusun menjadi jelas .

5. Proses Sertifikat Rusun Pekunden sejak tahun 2000 sampai sekarang \pm 7 tahun

6. Mengusahakan asuransi untuk kelangsungan Rusun Mengingat usia bangunan

7. Membentuk Apresiasi Pengelola Rumah Susun Indonesia (APERSI) di Semarang

Tahapan Pelaksanaan Pembanunan Rusun Pekunden :

2. Pra pembangunan rusun :

a. Penyuluhan :

- Penyuluhan tentang rencana pembangunan rusun oleh Ketua Bappeda Kota Semarang kepada warga Pekunden, Sekayu dan Miroto yang termasuk pemukim tanah milik negara yang akan dibangun rusun;

- Penjelasan PP No. 5 tahun 1990 tentang Peremajaan Pemukiman Kumuh untuk daerah perkotaan di atas tanah milik negara;

b. Menghimpun tanggapan masyarakat yang terkena proyek;

- Kesepakatan warga setuju pembangunan rusun apabila system ganti rugi/kompensasi tidak terlalu merugikan warga, dan setelah jadi mendapatkan prioritas pertama untuk 
menempati;

- selama pembangunan tidak terlantar dan diberi uang untuk pemondokan;

- pembangunan tidak membuat suasana kumuh baru, mempunyai KM/WC sendiri, tempat jemuran dan fasilitas lain;

- pelaksanaan secara manusiawi dan pendekatan;

- fasilitas rusun dilengkapi mushola, aula, taman, tempat bermain dll;penempatan penghuni disesuaikan seperi sebelum dibangun rusun;

- mendapatkan sertipikat hak;

c. Pengukuran tanah dan bangunan rumah dilokasi proyek;

- pengukuran dan penggambaran rumah lama yang akan dibongkar, lengkap dengan ukuran tanah dan bangunan;

d. Sosialisasi dari Bappeda dan Tim Satgas Rusun Kota Semarang tentang penghitungan kompensasi asset tanah dan bangunan lama dan kesepakatan warga;

- kompensasi tanah

: Rp. $10.000,-/ \mathrm{m}^{2}$;

- bangunan permanen

- bangunan semi permanen

- bangunan non permanen

: Rp. $75.000,-/ \mathrm{m}^{2}$;

: Rp. $50.000,-/ \mathrm{m}^{2}$;

- biaya kontrak sementara

: Rp. $25.000,-/ \mathrm{m}^{2}$;

- biaya pembongkaran rumah

: Rp. 150.000,-/KK;

: Rp. 50.000,-/pemilik;

- uang kompensasi tidak dibayarkan secara tunai, namun pemilik rumah dianggap sudah bayar uang muka dengan uang kompensasi yang diperolehnya secara langsung;

- jumlah kompensasi terkecil Rp. 500.000,- dan terbesar Rp. 17.440.500,-

- sertifikat tidak diperoleh secara langsung/memakan waktu.

e. Penandatanganan gambar rumah/tanah dan surat kesepakatan warga lokasi proyek;

- sebelum dibongkar sudah mendapatkan kompensasi sesuai dengan asset yang dimiliki (luas tanah, bangunan dan fasilitas yang dimiliki);

- sebelum membongkar rumah sudah mendapatkan biaya kontrakminimal satu tahun dan biaya pembongkaran rumah;

- penyewa/pengontrak mendapatkan biaya sendiri;

- tenggang waktu pembongkaran minimal satu bulan.

f. Jadwal pelaksanaan pembongkaran rumah/pindah sementara.

2. Pembangunan rusun :

a. Pemberitahuan gambar bangunan;

- rusun dibangun 5 blok : A, B, C, D, E. terdiri dari 108 unit rusun;

- tempat usaha dibangun di lantai dasar;

- rencana bangunan ukuran standar setiap petak $=7,5 \mathrm{~m} \mathrm{x} \mathrm{3,5} \mathrm{m}=27 \mathrm{~m}^{2}$ dilengkapi dengan KM/WC, dengan harga sarusun tiap Unit Rp 6.000.000,- (enam juta rupiah) karena mendapat subsidi yang harga aslinya tiap unit Rp 9.000.000,- (pada tanun 1992);

- untuk type 54 harga Rp 12.000.000,-

- untuk type 81 harga Rp 18.000.000,-

- dapat dicicil paling lambat 20 tahun, dengan cicilan Rp. 40.000,-/bulan atau Rp. 1350/hari;

b. Mengajukan usulan pemanfaatan lantai dasar untuk tempat usaha kepada Pimpro dan Pemda oleh wakil warga;

- Penyuluhan tata cara tinggal di rumah susun; 
- menjaga kebersihan dan ketertiban;

- mengutamakan kerukunan dan kelompok karena hidup bersama;

- pemakaian KM/WC, membuang sampah, menjemur pakaian dsb;

- perabot lama/rusak tidak dibawa ke rusun;

c. Pembagian rumah kepada warga yang berhak;

- pembagian rumah disesuaikan dengan urutan prioritas;

- untuk pemilik rumah diutamakan di lantai II, kecuali yang type 54, karena di lantai II hanya ada 2, yang lainndi lantai III dilihat dari jumlah uang kompensasi;

- ada beberapa warga yang tukar type, dari 81 ditukar 27 sebanyak 3, type 54 ditukar 27 sebanyak 2, dan type 27 ditukar 81 karena ada sisa dan mampu membayar angsuran;

- warga yang punya tempat usaha akan mendapat prioritas utama;

- pembagian rumah dan pengelolaan diserahkan kepada wkil warga;

- pengontrak diberi kesempatan untuk memiliki dengan angsuran.sewa;

- warga yang mendapatkan kompensasi mendapatkan unit rusun di lantai II;

- warga pengikut dan pengontrak mendapatkan unit rusun di lantai II dan III;

- sisanya diberikan warga sekitar yang mendesak dan belum punya rumah.

- rusun dibangun 88 unit : type $27=(73)$ unit, type $54=(10)$ unit, type $81=(5)$ unit;

- pembagian tempat telah disepakati :

- pemilik rumah : $81=(4$ warga $), 54=(8$ warga $), 27=(23$ warga $)$;

- pengikut / pengontrak 47 warga;

- $\quad$ sisa 6 unit rumah type $81=(1)$ unit dan type $27=(5)$ unit.

- pengelolaan selama satu tahun di bawah bimbingan PU Cipta Karya;

- lantai dasar akan diatur Pemda untuk usaha yang tidak mengandung resiko;

d. Peresmian rusun;

3. Pembentukan Paguyuban Perkampungan Rumah Susun :

d. Menetapkan program kerja;

e. Menyusun peraturan tata-tertib penghuni rusun;

f. Menyusun AD/ART;

Sampai saat ini dengan waktu yang hampir 19 tahun masyarakat belum mendapatkan sertipikat gratis yang sudah dijanjikan. Menurut Ketua PPRS Pekunden Ibu Hj Suatni Sutarman sedang dalam proses, dalam hal ini ditangani oleh DTKP Kota Semarang, yang menurutnya sudah diajukan ke Kantah BPN Kota Semarang, yang di klaim sejak tahun 2006 namun belum dapat menunjukkan bukti adanya permohonan masuk tersebut, dan menurut Kantah BPN Kota Semarang (Kasubsi HTPT) permohonan tersebut pernah diajukan namun hal ini belum dapat diproses dikarenakan adanya kekurangan berkas administrasi yaitu persyaratan adanya Pihak III sebagai Badan Hukum yang mengelola pembangunan rusun tersebut, hal ini belum dapat dipenuhi karena pembangunan rusun tersebut dilaksanakan dan dibiayai oleh Ditjend Ciptakarya Pusat. Menurut pihak DTKP menyatakan (Pemko) sudah menunjuk pihak ke III tersebut yaitu koperasi PDAM selaku pihak ketiga untuk mengelola rusun tersebut, namun sampai saat ini belum pernah mengajaknya berkomunikasi. Hingga saat ini, semua penghuni, baik yang berstatus sewa maupun hak milik rutin membayar PBB. Karena itu, PPRSP hanya mendesak Dinas Tata Kota dan Permukiman (DTKP) karena semua data ada di sana. Ke-50 pemilik rumah 
telah menuruti permintaan dinas tersebut untuk mengumpulkan fotokopi KK dan KTP dilengkapi materai sampai dua kali.

Menurut Ketua PPRSP sudah berulang kali melayangkan surat ke wali kota dan DTKP, bahkan sampai enam kali pergantian pengurus, tapi tetap tak ada realisasi. Karena tak memiliki sertifikat, mereka mengalami kesulitan untuk menjual rumahnya. Mau tak mau, mereka merelakan rumahnya dihargai rendah karena dijual di bawah tangan, menurut sumber dari Ketua PPRSP sudah banyak pemilikan rusun yang dipindahkan pemilikannya melaui jual beli dibawah tangan tanpa ada pengesahan dari pihak manapun, dengan harga berkisar 25 juta s/d 30 juta untuk satu unit rusun type 27. demikian pula untuk rusun sewa telah banyak dialih sewakan dengan jumlah \pm 25 rusun, dengan harga oper sewa sebesar \pm 25 juta dan Pemkot sendiri tidak melarang bahkan dapat diberikan balik nama dengan biaya 250.000. setiap transaksi, dan berdasarkan kesepakatan dikenakan pungutan wajib untuk pengelolaan paguyuban sebesar 2,5\% disetor ke paguyuban. PBB dibayar oleh semua penghuni baik pemilik maupun penyewa.

Rumah susun bukan sekedar rumah-rumah yang disusun begitu saja, tetapi membutuhkan sistem serta sarana yang harus dapat menunjang agar mekanisme orang-orang di dalamnya bisa befungsi baik. Agar sistem dapat berjalan dengan baik maka diperlukan pengaturanpengaturannya antara lain mengenai :

1. Kepemilikan rumah susun, sebagaimana diatur dalam pasal 8 Undang-Undang Nomor 16 Tahun 1985 yang menyatakan bahwa, satuan rumah susun dapat dimiliki oleh perorangan atau badan hukum yang memenuhi syarat sebagai pemegang hak serta hak milik atas satuan rumah susun adalah hak milik yang bersifat perorangan atau terpisah.

2. Jaminan hukum bagi pemilik rumah susun, dalam rangka menjamin kepastian hukum dan kepastian hak bagi pemilik satuan rumah susun, maka diperlukan aIat bukti yang kuat, berupa "sertifikat hak milik atas satuan rumah susun" sebagaimana yang diatur dalam Undang-Undang Nomer 16 Tahun 1985 dan Peraturan Pemerintah Nomer 4 Tahun 1988 tentang rumah susun.

3. Mengenai kehidupan para penghuninya diatur dalam Pasal 62 - 70 Peraturan Pemerintah Nomer 4 Tahun 1988 tentang rumah susun yang mengatur bahwa perhimpunan penghuni oleh peraturan perundang-undangan diberi kedudukan sebagai badan hukum yang susunan organisasi, hak, dan kewajibannya diatur dalam Anggaran Dasar dan Anggaran Rumah Tangganya, sehingga dapat bertindak keluar dan ke dalam atas nama perhimpunan penghuni dan pemilik dan dengan wewenang yang dimilikinya dapat mewujudkan ketertiban dan ketenteraman dalam lingkungan rumah susun.

4. Perolehan tanah bagi pembangunan rumah susun tersebut. Pada Pasal 7 Undang-Undang Nomer 16 Tahun 1985 menetapkan bahwa rumah susun hanya dapat dibangun di atas tanah yang berstatus hak milik, hak guna bangunan, hak pakai atas tanah negara, dan hak pengelolaan yang diberikan kepada perusahaan pembangunan perumahan yang seluruh modalnya berasal dari pemerintah/pemerintah daerah.

5. Serta mengenai pengaturan-pengaturan yang mengarah pada sistem dan mekanisme rumah susun.

Pemilik rumah susun (50 KK) yang menempati lantai II dan III menurut daftar inventarisasi asset dikenakan pembayaran kekurangan atas nilai unit satuan sarusun yang mereka peroleh sesuai proporsi masing-masing, namun mulai tahun 1992 sampai saat ini belum pernah membayar/dipungut kekurangan tersebut, yang pada awalnya dapat diangsut bulanan. Demikian 
pula untuk penghuni sewa mereka yang menyewa mulai tahun 1992 sampai tahun 1999 tidak ditarik uang sewa, baru mulai bayar uang sewa tahun 1999. Bahkan kewajiban membayar uang sewa yang sering nunggak tidak diberikan sanksi oleh Pemkot selaku pengelola.

Uang sewa semula Rp. 13.500 s/d Rp. 15000 disetor langsung ke Pemda. Untuk tahun 2010 di naikkan menjadi Rp. 40.000 dan Rp. 60.000 per bulan.

Pengembangan konsep konsolidasi tanah dengan pendekatan pembangunan perumahan vertikal untuk menata kembali penguasaan, pemilikan, penggunaan dan pemanfaatan tanah di wilayah perkotaan Menurut Ketua REI Jawa Tengah kebutuhan akan hunian layak bagi warga berpenghasilan menengah ke bawah sudah sangat mendesak di kota Semarang yang kepadattan penduduknya > 13 juta jiwa/km2, namun sampai saat ini belum pernah melaksanakan pembangunan rusun milik di Propinsi Jawa Tengah REI pernah mencoba mengkalkulasi rencana pembangunan rusun sederhana untuk menunjang pembangunan seribu tower dengan memanfaatkan tanah asset perumnas di dekat Kantah BPN Kota Semarang, apabila dibangun 20 lantai dengan unit sarusun 600 unit maka akan terkaver biaya untuk pengembangan dengan nilai jual < 144 juta rupiah, namun karena adanya aturan tidak boleh dibangun lebih dari 10 lantai nilai jualnya akan menjadi lebih besar berkisar antara $300 \mathrm{~s} / \mathrm{d} 400$ juta/unit rusun. Sehingga menurut Ketua REI Jawa Tengah lebih baik kalau dibangun kodominium/apartemen yang harganya akan menjadi berkisar 500 s/d 600 juta/unit.

Pengembangan konsolidasi tanah vertical menurut Ketua REI Jawa Tengah sangat dimungkinkan untuk dikembangkan di Kota Semarang, yaitu dengan melibatkan stake-holders terkait sebagaimana sudah sering dilaksanakan, guna menunjang pendanaan dalam pengembangan pembangunannya. Missal DPU untuk pembangunan infrastukturnya, REI dalam mengupayakan permodalan untuk pembangunan fisiknya, Bapermas dalam pemberdayaan masyarakat untuk meningkatkan penghasilan dan pendapatan penghuni sehingga mampu untuk membayar angsuran. Untuk itu REI Jawa Tengah sedang menyususun proposal untuk pengembangan konsolidasi tanah vertikal untuk menangani daerah kumuh

\section{Kota Surabaya}

Kebijakan yang berkaitan dengan pengembangan konsep konsolidasi tanah dengan pendekatan pembangunan perumahan secara vertikal belum ada di Provinsi Jawa Timur. Yang sudah ada adalah Peraturan Daerah Kota Surabaya No 3 tahun 2005 tentang Rumah Susun dan Peraturan Daerah Kota Surabaya No. 2 tahun 2005 tentang Pemakaian Rumah Susun.

Peraturan daerah yang sudah dikeluarkan oleh pemerintah daerah merupakan landasan hukum bagi Pemerintah Daerah untuk membangun Rumah Susun. Dalam Perda Rusun Kota Surabaya diatur mengenai :

- Ketentuan Umum

- Persyaratan Pembangunan Rumah Susun

- Pertelaan Rumah Susun

- Izin Layak Huni

- Pemisahan Satuan Rusun

- Penghunian dan Pengelolaan Rusun

- Penggunaan Rusun

- Pengawasan dan Pembinaan 
Dalam Perda Rusun Kota Surabaya tentang Rumah Susun disebutkan bahwa Penggunaan rumah susun terdiri dari rumah susun hunian, rumah susun bukan hunian dan rumah susun penggunaan campuran. Adapun penentuan penggunaan Rusun tersebut harus sudah dinyatakan pada saat mengajukan izin mendirikan bangunan dan selanjutnya dinyatakan dalam Izin Mendirikan bangunan.

Adapun Peraturan Daerah Kota Surabaya No. 2 tahun 2005 tentang Pemakaian Rumah Susun mengatur mengenai Pemanfaatan Rumah Susun, dapat dimanfaatkan oleh setiap penduduk Surabay yang belum mempunyai rumah tinggal sebagai tempat hunian. Bentuk pemanfaatan dengan cara izin pemakaian rusun dan perjanjian sewa menyewa rumah. Izin pemakaian rumah susun dapat diterbitkan untuk rusun milik Pemda.

Kebijakan mengenai konsolidasi tanah vertikal harus ada peraturan tersendiri, tidak mengacu kepada UU Rumah Susun, karena kebijakan rumah susun hanya mengatur bagaimana sistim pemilikan hak saja tidak menyebutkan mengenai proses yang harus dilalui untuk membangun rumah susun, sedangkan konsolidasi tanah mempunyai prinsip dasar yaitu :

a) Membangun tanpa menggusur;

b) Kegiatan pembangunan dari rakyat, oleh rakyat dan untuk rakyat;

c) Dilaksanakan berdasarkan kesepakatan bersama (musyawarah);

d) Penyediaan tanah melalui STUP (Sumbangan Tanah Untuk Pembangunan);

e) Pembangunan dibiayai melalui TPBP (Tanah Pengganti Biaya Pelaksanaan);

f) Transparansi;

g) Keadilan;

h) Kepastian hak atas tanah dengan lingkungan yang tertata

Adapun peraturan yang mengatur mengenai konsolidasi tanah yaitu Peraturan Kepala Badan Pertanahan Nasional No. 4 Tahun 1991 tentang Konsolidasi Tanah, tidak dapat digunakan untuk melaksanakan konsolidasi tanah secara vertikal, perlu ada kebijakan baru yang merupakan yang sekaligus mengatur mengenai pelaksanaan konsolidasinya dan pembangunan rumah susun.

Penyediaan lokasi pembangunan Rumah Susun (Rusun) di Surabaya mengacu pada konsep tata ruang kota, sedangkan pemilihan lokasi pembangunan rusun mengacu pada tujuan dibangunnya rusun tersebut, antara lain :

1. Peremajaan pemukiman padat dan kumuh

Pemilihan lokasi didasarkan pada tingkat kepadatan pemukiman di kawasan kumuh

2. Pusat kegiatan ekonomi

Pemilihan lokasi didasarkan pada kawasan pusat kegiatan ekonomi/ industri

3. Kawasan Khusus

Pemilihan lokasi didasarkan pada daerah cepat tumbuh dan daerah pinggiran kota sebagai pendukung kawasan industri sekitarnya

4. Pusat Pendidikan

Pemilihan lokasi didasarkan pada ketersediaan lahan di kawasan pusat pendidikan, dsb.

Dari segi Pendanaan, ada beberapa alternatif pembiayaan :

1. Dana APBN melalui Departemen PU

Diprioritaskan untuk melakukan kegiatan rehabilitasi/revitalisasi suatu kawasan. 
2. Dana APBN melalui kementrian Negara Perumahan rakyat

Diarahkan untuk kegiatan pembangunan baru rumah susun

3. Dana APBD Provinsi/Kabupaten/Kota

Diarahkan untuk melakukan pembangunan baru maupun rehabilitasi rumah susun

4. Pihak III/Swasta

Diarahkan pada kegiatan pembangunan rumah susun pada kawasan strategis.

Pemerintah Provinsi Jawa Timur sangat akomodatif dalam menangani kebutuhan masyarakat untuk perumahan sehingga sudah cukup banyak rumah susun yang dibangun, dan yang berlokasi di kota Surabaya antara lain adalah :

1. Rusunami yang dibangun oleh Perumnas terdapat di kelurahan Menanggal, dikenal dengan nama Rusunami Cipta Menanggal dibangun pada tahun 1987 sebanyak 14 blok s, sekarang dikelola oleh PPRS.

2. Rusunawa Urip Sumoharjo dibangun pada tahun 1975 dan direhabilitasi pada tahun 2004/2005 dengan dana APBD I sebanyak 3 blok.

3. Rusunawa Penjaringansari, dibangun pada tahun 1995 sebanyak 3 blok dan tahun 2004 sebanyak 3 blok dengan dana APBN dan dikelola oleh Pemerintah Kota Surabaya.

4. Rusunawa Sumbo, dibangun pada tahun 1989/1990 sebanyak 10 blok dengan dana APBN dan dikelola oleh Pemkot Surabaya.

5. Rusunawa Waru Gunung, dibangun pada tahun 1996 oleh Perumnas sebanyak 5 twin blok dan dikelola oleh Pemkot Surabaya

6. Rusunawa Siwalankerto dibangun secara bertahap pada tahun 2003/2004 oleh Perumnas sebanyak 2 twin blok, pada tahun 2005 dibangun oleh Pemprov sebanyak 1 twin blok dan pada tahun 2006 dibangun oleh Kementrian Negara Perumahan Rakya sebanyak 2 twin blok dikelola oleh Pemprov Jatim

7. Rusunawa Wonorejo dibangun pada tahun 2004 sebanyak 1 twin blok dan tahun 2006 sebanyak 2 twin blok dengan dana APBN dikelola oleh Pemkot Surabaya

Kondisi rumah susun sederhana sewa (rusunawa) di Surabaya banyak yang memprihatinkan. Dari enam rusun yang telah dioperasikan, empat di antaranya tampak kumuh seperti di rusunawa Warugunung, Penjaringansari I, Dupak Bangunrejo, dan Sumbo. Sementara dua lainnya, yakni rusunawa Urip Sumoharjo yang baru direnovasi serta Wonorejo yang baru ditempati cukup terkontrol kebersihannya.

Memperhatikan kekumuhan di sebagian besar rusunawa tampak seperti memindahkan kekumuhan dari bantaran kali ke rusunawa. Masalah ini dapat saja terjadi karena kurangnya sosialisasi pemerintah kepada masyarakat penghuni untuk menjaga lingkungannya, oleh karena itu penghuni rusunawa seharusnya dididik agar bisa bertanggung jawab pada lingkungan dengan memelihara kebersihan, kerukunan, dan keharmonisan.

Sampai saat ini belum pernah dilaksanakan konsolidasi tanah vertikal (KTV) di Kota Surabaya, namun pembangunan rumah susun yang mirip konsep KTV pernah dilakukan yaitu :

a) di Kampung Sumbo, kelurahan Simolawang Kecamatan Simokerto, konseptornya adalah Johan Silaas. Daerah ini semula adalah kandang sapi yang dikelola oleh orang madura dan terdapat rumah pegawai Dinas Kebersihan kesemuanya di atas tanah Pemerintah Kota, karena kumuh akhirnya dibangun rusun dengan prioritas orang-orang yang semula menetap di daerah tersebut. Jika mereka semula rumahnya besar maka mendapatkan unit lebih banyak dari penghuni lainnya, seperti bapak Kabut yang mendapatkan 9 unit rusun. 
Rusun yang mulai dibangun pada 14 Desember 1989 dan baru ditempati pada Agustus 1994 itu terdiri atas 603 unit dalam sebelas blok, A--K

b) Di daerah Bangun rejo, semula kampung yang tanahnya berstatus tanah Pemkot, karena kumuh akhirnya dibangun rusun dengan prioritas yang bertempat tinggal, yang rumahnya besar mendapatkan unit lebih banyak seperti Ibu Misni yang mendapatkan 4 unit.

Rusun tersebut di atas mendapatkan fasilitas jalan paving, lampu mercury hanya belum ada fasilitas olah raga, dan dibangun sebelum adanya program 1000 tower.

Seksi Pengaturan dan Penataan Pertanahan Kantah Surabaya telah melakukan inventarisasi kondisi fisik wilayah, penguasaan tanah serta aspek sosial lainnya dalam rangka rencana pembangunan rumah susun melalui konsolidasi tanah, yang diarahkan pada lima lokasi di Kota Surabaya, yaitu :

Tabel 42. Rencana lokasi konsolidasi tanah dengan pembangunan vertikal di Kota Surabaya

\begin{tabular}{|c|c|c|c|c|c|c|c|}
\hline No & Lokasi & RTRW & $\begin{array}{l}\text { Penggunaan } \\
\text { Tanah }\end{array}$ & $\begin{array}{l}\text { Penggunaan } \\
\text { Tanah }\end{array}$ & $\begin{array}{l}\text { Kepadatan } \\
\text { Penduduk }\end{array}$ & $\begin{array}{l}\text { Pendapatan } \\
\text { /hari }\end{array}$ & $\begin{array}{ll}\text { Jaringan } & \\
\text { jalan } & \& \\
\text { drainase } & \end{array}$ \\
\hline 1 & $\begin{array}{l}\text { Bantaran } \\
\text { kali } \\
\text { Surabaya } \\
\text { Kel. Jagir \& } \\
\text { Ngagelrejo, } \\
\text { Kec. } \\
\text { Wonokromo, } \\
\text { Kota } \\
\text { Surabaya }\end{array}$ & $\begin{array}{l}\text { Perda No. } \\
\text { 3/2007, } \\
\text { untuk } \\
\text { Ruang } \\
\text { Terbuka } \\
\text { Hijau (RTH) }\end{array}$ & $\begin{array}{l}\text { pemukiman } \\
\text { padat, kumuh, } \\
\text { tidak teratur } \\
\text { dan illegal }\end{array}$ & $\begin{array}{l}\text { Tanah } \\
\text { Negara }( \\
\text { Penguasaan } \\
\text { Pengairan ) }\end{array}$ & $\begin{array}{l}17.341 \\
\text { jiwa/km2 }\end{array}$ & Rp. 35.000,- & $\begin{array}{l}\text { sempit, dan } \\
\text { tidak } \\
\text { beraturan }\end{array}$ \\
\hline 2 & $\begin{array}{l}\text { Gembong } \\
\text { Kel. } \\
\text { Bongkaran, } \\
\text { Kec. Pabean } \\
\text { Cantikan, } \\
\text { Kota } \\
\text { Surabaya }\end{array}$ & $\begin{array}{l}\text { untuk } \\
\text { perdagangan } \\
\text { dan jasa }\end{array}$ & $\begin{array}{l}\text { Perkampungan } \\
\text { Padat }\end{array}$ & $\begin{array}{l}\text { Tanah Hak } \\
\text { Milik dan } \\
\text { Hak Guna } \\
\text { Bangunan }\end{array}$ & $\begin{array}{l}10.698 \\
\text { jiwa/km2 }\end{array}$ & Rp. 45.000,- & $\begin{array}{l}\text { Jalan } \\
\text { sempit } \\
\text { sudah } \\
\text { dipaving, } \\
\text { drainase: } \\
\text { sempit/tidak } \\
\text { beraturan }\end{array}$ \\
\hline 3 & $\begin{array}{l}\text { Gubeng- } \\
\text { Kalibutuh, } \\
\text { Kel. Tembok } \\
\text { Dukuh, Kec. } \\
\text { Bubutan }\end{array}$ & $\begin{array}{l}\text { untuk } \\
\text { perdagangan } \\
\text { dan jasa }\end{array}$ & $\begin{array}{l}\text { Perkampungan } \\
\text { Padat }\end{array}$ & $\begin{array}{l}\text { Tanah Hak } \\
\text { Milik dan } \\
\text { hak Guna } \\
\text { bangunan }\end{array}$ & $\begin{array}{l}22.768 \\
\text { jiwa/km2 }\end{array}$ & Rp. 45.000,- & $\begin{array}{l}\text { Jalan } \\
\text { sempit } \\
\text { sudah } \\
\text { diaspal, } \\
\text { drainase: } \\
\text { sempit/tidak } \\
\text { beraturan }\end{array}$ \\
\hline 4 & $\begin{array}{l}\text { Dukuh } \\
\text { Sutorejo, } \\
\text { kec. } \\
\text { Mulyorejo, } \\
\text { Kota } \\
\text { Surabaya } \\
\end{array}$ & $\begin{array}{l}\text { untuk } \\
\text { perumahan }\end{array}$ & $\begin{array}{l}\text { Pemukiman } \\
\text { padat }\end{array}$ & $\begin{array}{l}\text { Tanah hak } \\
\text { yasan dan } \\
\text { hak Milik }\end{array}$ & $\begin{array}{l}6.002 \\
\text { jiwa/km2 }\end{array}$ & Rp. 40.000,- & $\begin{array}{l}\text { Jalan tanah } \\
\text { sempit, } \\
\text { drainase : } \\
\text { sempit/tidak } \\
\text { beraturan }\end{array}$ \\
\hline 5 & $\begin{array}{l}\text { Kel. } \\
\text { Keputih, } \\
\text { Kec. } \\
\text { Sukolilo, } \\
\text { Kota } \\
\text { Surabaya }\end{array}$ & $\begin{array}{l}\text { untuk } \\
\text { perumahan }\end{array}$ & Pemukiman & $\begin{array}{l}\text { Tanah hak } \\
\text { yasan dan } \\
\text { hak Milik }\end{array}$ & $\begin{array}{l}4.227 \\
\text { jiwa/km2 }\end{array}$ & Rp. 40.000,- & $\begin{array}{l}\text { Jalan tanah } \\
\text { sempit, } \\
\text { drainase : } \\
\text { sempit/tidak } \\
\text { beraturan }\end{array}$ \\
\hline
\end{tabular}




\section{Kota Yogyakarta}

Kebijakan yang berkaitan dengan pengembangan konsep konsolidasi tanah dengan pendekatan pembangunan perumahan secara vertikal belum ada di provinsi Yogyakarta. Yang sudah dilaksanakan adalah pembangunan rumah susun dengan konsep rumah susun sewa. Rumah susun sederhana milik belum ada karena Peraturan Daerah yang menjabarkan PP No. 4 tahun 1988 tentang Rumah Susun, sampai saat ini belum dimiliki oleh Pemerintah Daerah Provinsi DIY dan Pemerintah Daerah Kabupaten/Kota di wilayah DIY, sehingga landasan hukum yang digunakan bersifat pedoman yang dikeluarkan dalam bentuk keputusan Walikota, antara lain :

- Keputusan Walikota Yogyakarta No.85/2004 tentang Pengelolaan Rumah Susun Milik Pemerintah Kota Yogyakarta

- Surat Keputusan Walikota Yogyakarta No. 369/KD/Tahun 2004 tentang Pembentukan Tim Seleksi Badan Pengelola Rumah Susun Milik Pemerintah pemerintah Kota Yogyakarta

- Surat Keputusan Walikota Yogyakarta No. 377/KD/Tahun 2004 tentang Pembentukan Tim Pembinaan dan Pengawasan Pengelolaan Rumah Susun Milik Pemerintah Kota Yogyakarta.

- Surat Keputusan Walikota Yogyakarta No. 378/KD/Tahun 2004 tentang Pembentukan Tim Seleksi Penghuni Rumah Susun Milik Pemerintah Kota Yogyakarta

- Peraturan walikota Yogyakarta No. 37 tahun 2005 tentang Mekanisme Pengelolaan Keuangan Rumah Susun Milik Pemerintah Kota Yogyakarta

Berdasarkan keputusan tersebut di atas maka dibentuk Tim Pembinaan dan Pengawasan Pengelolaan Rumah Susun milik Pemerintah Kota Yogyakarta, dimana komposisi anggota tim terdiri dari Kimpraswil, Dinas Sosial, Bappeda, Bagian Hukum Pemda, Camat, dsb.

Pembagian tugas dalam pembangunan rumah susun dilaksanakan dalam tiga tahapan:

a) Sosialisasi dilakukan oleh Kimpraswil dan Pemerintah Kota, sedangkan penyiapan lahan oleh Pemerintah Kota.

b) Pembangunan fisik dibiaya oleh Kimpraswil Pusat sedangkan pengawasan di lapangan dilakukan oleh Kimpraswil daerah dan Pemerintah Kota.

c) Pasca pembangunan fisik, yaitu pengelolaan Rumah Susun di lakukan oleh Dinas Sosial.

Tabel 43. Pembangunan Rusun Sewa di Kota Yogyakarta :

\begin{tabular}{|c|c|c|c|c|c|c|c|c|}
\hline No. & Lokasi & Luas & Status & $\begin{array}{c}\text { Jumlah } \\
\text { unit }\end{array}$ & Penghunian & $\begin{array}{c}\text { Asal } \\
\text { penghuni }\end{array}$ & $\begin{array}{l}\text { Penghasilan } \\
\text { penghuni }\end{array}$ & Pengelola \\
\hline 1 & $\begin{array}{l}\text { Danurejan, } \\
\text { Suryatmajan, } \\
\text { Kota Yogjakarta }\end{array}$ & $\begin{array}{l}0,3 \\
\mathrm{Ha}\end{array}$ & Pemda & 72 unit & sewa & $\begin{array}{l}100 \% \\
\text { penduduk } \\
\text { Kota } \\
\text { Yogjakarta }\end{array}$ & $<1,5$ juta & $\begin{array}{l}\text { Badan Pengelola } \\
\text { Rusunawa } \\
\text { Cokrodirjan } \\
\text { (masyarakat) }\end{array}$ \\
\hline 2 & $\begin{array}{l}\text { Danurejan, } \\
\text { Tegalpanggung } \\
\text { Kota Yogjakarta }\end{array}$ & $\begin{array}{l}0,1 \\
\mathrm{Ha}\end{array}$ & $\begin{array}{l}\text { Milik } \\
\text { Pemkot }\end{array}$ & 68 unit & sewa & $\begin{array}{l}100 \% \\
\text { penduduk } \\
\text { Kota } \\
\text { Yogjakarta }\end{array}$ & $<1,5$ juta & $\begin{array}{l}\text { Badan Pengelola } \\
\text { Rusunawa } \\
\text { Tegalpanggung } \\
\text { (masyarakat) }\end{array}$ \\
\hline 3 & $\begin{array}{l}\text { Jetis, } \\
\text { Gowongan, } \\
\text { Kota Yogjakarta }\end{array}$ & $\begin{array}{l}0,27 \\
\mathrm{Ha}\end{array}$ & $\begin{array}{l}\text { Milik } \\
\text { Pemda }\end{array}$ & $\begin{array}{l}96 \text { unit } \\
\text { (1 twin } \\
\text { block) }\end{array}$ & sewa & $\begin{array}{l}100 \% \\
\text { penduduk } \\
\text { Kota } \\
\text { Yogjakarta, }\end{array}$ & $\begin{array}{l}750 \text { ribu - } \\
2,5 \text { juta }\end{array}$ & $\begin{array}{l}\text { UPTD/Disnakertrans } \\
\text { Prov.DIY }\end{array}$ \\
\hline 4 & $\begin{array}{l}\text { Jetis, } \\
\text { Gowongan, } \\
\text { Kota Yogjakarta }\end{array}$ & $\begin{array}{l}0,25 \\
\mathrm{Ha}\end{array}$ & $\begin{array}{l}\text { Milik } \\
\text { Pemda }\end{array}$ & $\begin{array}{l}96 \text { unit } \\
\text { (1 twin } \\
\text { block) }\end{array}$ & sewa & $\begin{array}{l}100 \% \\
\text { penduduk } \\
\text { Kota } \\
\text { Yogjakarta, }\end{array}$ & $\begin{array}{l}750 \text { ribu }- \\
2,5 \text { juta }\end{array}$ & $\begin{array}{l}\text { UPTD/Disnakertrans } \\
\text { Prov.DIY }\end{array}$ \\
\hline
\end{tabular}




\section{Konsep konsolidasi tanah dengan pendekatan pembangunan perumahan vertikal untuk menata kembali penguasaan, pemilikan, penggunaan dan pemanfaatan tanah di wilayah perkotaan}

Konsolidasi tanah pada hakekatnya adalah suatu penataan tanah yang dilengkapi dengan fasilitas umum dan fasilitas sosial. Alasan dilakukannya konsolidasi tanah untuk membantu pemerintah daerah untuk menata bagian wilayahnya yang tidak teratur menjadi teratur sesuai Rencana Tata Ruang dan Rencana Pembangunan daerah.

Dalam rangka mendorong pembangunan rumah susun melalui konsolidasi tanah maka perlu dipertimbangkan beberapa aspek, antara lain:

a. aspek fisik dalam menetapkan lokasi

dalam rangka penataan kembali penguasaan, pemilikan, dan penggunaan tanah dari lingkungan yang tidak teratur menjadi teratur perlu dipertimbangkan beberapa faktor penting antara lain :

- luas penguasaan/pemilikan tanah, karena penguasaan dan pemilikan tanah yang terlalu sempit cenderung menimbulkan lingkungan yang kumuh dan tidak teratur

- status penguasaan dan pemilikan tanah, bahwa obyek konsolidasi tanah tidak terbatas pada tanah hak milik saja tetapi dimungkinkan untuk tanah Pemda dan tanah negara.

- Ketidak teraturan penggunaan dan pemanfaatan tanah yang cenderung menimbulkan kekumuhan (darah slum)

- Tingkat kepadatan penduduk yang tinggi biasanya cenderung berkembang menjadi daerah slum sehingga prioritas obyek lokasi diarahkan pada daerah yang tingkat kepadatan penduduknya tinggi sesuai dengan Keppres No. 22 tahun 2006, yaitu wilayah yang tingkat kepadatan penduduknya lebih dari 1,5 juta jiwa/km2.

- Prasarana Jalan, merupakan faktor penting dalam kehidupan sehari-hari, dan sangat penting untuk menunjang aktivitas kegiatan masyarakat. Lingkungan yang miskin prasarana jalan perlu mendapatkan prioritas untuk segera diatur dan ditata.

b. aspek Sosial

Tinggal di rumah susun merupakan budaya yang relatif baru bagi masyarakat kita, sehingga seringkali kegiatan sehari-hari yang dilakukan pada saat tinggal di rumah biasa (tidak susun) terbawa ke lingkungan rumah susun, yang antara lain sebagai berikut:

- Berbicara dan menggunakan perangkat audio dengan keras, sehingga mengganggu tetangga kamar maupun penghuni secara keseluruhan.

- Mengutamakan kepentingan individu dalam menggunakan fasilitas umum seperti, tangga, selasar depan kamar yang juga berfungsi sebagai jalan akses bagi tetangga, dapur dan kamar mandi umum, tempat bermain umum bagi anak-anak, parkir dan fasilitas umum lainnya.

- Menjemur pakaian keluar jendela, sehingga merusak pemandangan dan dapat meneteskan air dari pakaian yang masih basah ke jemuran pakaian yang sudah kering di bawahnya. 
- Tanpa disadari selalu membuang sampah atau barang tidak berharga lainnya ke luar yang dapat mengganggu kenyamanan penghuni lainya, khususnya dilantai bawah.

- Karena terletak saling berdekatan, maka segala kegiatan, harta benda tetangga jelas terlihat, sehingga sering menjadi pergunjingan dan saling cemburu.

- Kurangnya kesadaran penghuni dalam memelihara fasilitas umum.

c. aspek ekonomi

- Kontinuitas penghasilan penghuni rumah susun

- Kecemburuan secara ekonomi antar penghuni.

- Kriminalitas diantara sesama penghuni.

- Terlambat membayar sewa, air, listrik dan iuran lainnya sebagai penghuni.

Dilihat dari berbagai aspek tersebut di atas, Kota Yogyakarta sudah memenuhi unsur untuk dilakukan konsolidasi tanah secara vertikal. Tetapi peraturan perundangan yang berkaitan dengan pelaksanaan konsolidasi tanah secara vertikal belum mendukung sepenuhnya, antara lain belum adanya Peraturan Daerah mengenai Rumah Susun termasuk juga peraturan yang berkaitan dengan pelaksanaan konsolidasi tanah secara vertikal, sehingga pembangunan perumahan secara vertikal dilaksanakan melalui pembangunan rusunawa.

Konsep pembangunan rusunawa di lokasi penelitian sebenarnya identik dengan penataan pemukiman melalui konsolidasi tanah secara vertikal, perbedaannya hanya terletak pada perolehan hasil pembangunan berupa unit hunian yang dapat dimiliki secara hukum (mempunyai kepastian hukum).

\section{Kota Banjarmasin}

Sasaran Konsolidasi Tanah Perkotaan adalah pro rakyat, namun lokasi yang terdapat di Kota Banjarmasin masih menjadi kendala yang cukup besar apabila di bangun Rumah Susun Sederhana Sewa (Rusunawa) dimana lokasi tanahnya sebagian besar adalah tanah gambut yang memerlukan biaya besar untuk pembangunan Rusunawa tersebut, dimana untuk biaya pengurukannya saja sudah memakan biaya yang cukup besar ditambah lagi konstruksi tanah yang relatif tidak kuat untuk menyokong bangunan lebih dari empat lantai tersebut. Kendala yang lain adalah terlihat dari culture masyarakat Banjar sendiri yang lebih memilih untuk tinggal di rumah yang memiliki luas pekarangan yang besar. Konsolidasi tanah di Tanjung (Tabalong) Rusunawa dibangun oleh Kimpraswil sedangkan tanahnya diperoleh dari tanah wakaf dari pesantren ( 3 blok).

Keputusan Walikota mengenai bekas lokasi oleh Pemerintah Kota dijadikan obyek konsolidasi tetapi belum terjadi kesepakatan karena dijadikan setup, tiap depan rumah orang dipotong 2 m untuk jalan bersama tetapi banyak masyarakat yang tidak mau diatur, namun pada akhirnya dibangun sendiri (daerahnya adalah Kelurahan Alalak Tengah dan Alalak Selatan Kecamatan Banjarmasin Utara dengan luas $44.443 \mathrm{~m}^{2}$ (250 bidang). Rusunawa di Kelurahan 
Kelayen Selatan (Kecamatan Banjarmasin Selatan) Rusunawa yang mengelola adalah Kimprasko dan Dinas Tata Kota Rusunawa tujuh blok dan lima lantai.

Rusunawa yang terdapat di Kota Banjarmasin (Kelurahan Kelayan Selatan Kecamatan Banjarmasin Selatan) di mana lokasi semula adalah bekas lokalisasi kemudian ditutup oleh Pemkot yang diberikan bantuan dana oleh Departemen PU lalu diteruskan ke Ditjen Cipta Karya baru ada 2 twin blok asetnya belum diberikan ke Pemda tetapi sampai saat ini pengelolaannya ke Pemda/penyerahan sementara sedangkan yang satu twin blok lagi direncanakan akan dibangun tahun ini (tanah Pemda dibangun oleh Cipta Karya) lima lantai. Lantai bawah diperuntukkan sebagai sarana umum seperti TPA dan kantor pengelola serta dijadikan sebagai tempat usaha. Berdasarkan Perda Nomor 2 Tahun 2009 tentang Pengelolaan Rumah Susun Sederhana Sewa maka mengenai sewa kontraknya hanya berlaku selama tiga tahun dan setelahnya dapat diperpanjang hanya satu kali saja.

Konsolidasi tanah bertujuan untuk memanfaatkan tanah secara optimal, seimbang, dan lestari dengan meningkatkan efisiensi pengunaan tanah dan pemanfaatannya, sehingga dengan konsolidasi tanah tersebut diharapkan dapat diambil manfaat antara lain sebagai berikut :

a. Peningkatan efisiensi dan produktivitas penggunaan tanah, ruang dan daya tampung kota;

b. Memenuhi kebutuhan akan adanya lingkungan yang teratur, tertib dan sehat;

c. Peningkatan produktifitas masyarakat dan daya saing kota;

d. Meningkatkan hasil-hasil pembangunan pemukiman sehingga dapat dinikmati langsung oleh pemilik tanah;

e. Peningkatan kualitas hidup masyarakat berpenghasilan menengah - ke bawah dan pencegahan tumbuhnya kawasan kumuh perkotaan;

f. Mempercepat laju pembangunan wilayah permukiman;

g. Menertibkan administrasi pertanahan serta menghemat pengeluaran dana Pemerintah untuk biaya pembangunan prasarana dan fasilitas umum;

Untuk mengatasi kekumuhan dan menghindari pemukinan liar, pemerintah melalui Dinas Tata Kota Banjarmasin menyediakan rumah susun sederhana dengan sistem sewa (rusunawa) di Jl. Tembus Mantuil, Kelurahan Kelayan Selatan, Kota Banjarmasin. Adapun menurut Kepala Unit Pelaksana Teknis Dinas (UPTD) Rusunawa Ganda Maghfirah dimana selama ini perumahan di Banjarmasin terkonsentrasi pada beberapa titik. Di samping itu juga terdapat kawasan di pinggir sungai yang harus diperbaiki, selama tidak ada penampungan keberadaan rusunawa bisa menjadi solusi. Dengan demikian Pemerintah dalam membangun Rusunawa tersebut tidak mengharap profit, melainkan untuk mengatasi berbagai permasalahan di perkotaan yang sasarannya diperuntukkan bagi masyarakat berpenghasilan rendah yaitu mereka yang berpenghasilan setiap bulannya satu-dua kali Upah Minimum Provinsi (UMP) Kalimantan Selatan dan belum memiliki tempat tinggal yang tetap. Di sisi lain pembangunan Rusunawa di Kota Banjarmasin bertujuan untuk menyediakan tempat tinggal yang layak, memenuhi persyaratan kesehatan, lingkungan yang aman, nyaman dan terjangkau oleh warga miskin.

Rusunawa Ganda Maghfirah memiliki satu tower yang berisi 96 kamar. Khusus untuk lantai dasar digunakan sebagai ruang terbuka dan kantor. Hanya lantai dua sampai lima yang disewakan, masing-masing kamar memiliki luas 3x7 meter (type 21), idealnya maksimum dihuni oleh 4 orang dalam satu keluarga. Harga sewa Rusunawa tersebut terbilang murah sebesar Rp. 150.000 s/d Rp. 180.000 


\section{BAB V \\ PEMBAHASAN}

A. Sejauhmana konsep konsolidasi tanah dengan pendekatan pembangunan perumahan vertikal layak dilaksanakan/dikembangkan secara fisik, ekonomi dan sosial untuk menata kembali penguasaan, pemilikan, penggunaan dan pemanfaatan tanah di wilayah perkotaan

Dalam kegiatan pembangunan di berbagai kota di tanah air, masalah yang paling dominan adalah terbatasnya ketersediaan tanah. Tanah tidak mengalami pertambahan namun jumlah penduduk mengalami peningkatan yang sangat tinggi baik karena kelahiran maupun karena urbanisasi. Akibatnya di kota-kota besar sangat mudah untuk menemukan daerah padat penduduk dengan kondisi lingkungan yang kurang sehat, tidak teratur dan tampak kumuh.

Data kepadatan penduduk yang diperoleh dari BPS menunjukkan bahwa di Lokasi sampel Penelitian untuk tingkat propinsi menunjukkan provinsi terpadat adalah 1) Jawa Barat, 1.160 jiwa/km2, 2) DI Yogyakarta, 1.084 jiwa/km2, 3) DI Jawa Tengah, 995 jiwa/km2, 4) Jawa Timur, 795 jiwa/km2, 5) Sumatera Utara, 181 jiwa/km2, 6) Sulawesi Selatan, 129 jiwa/km2, 7) Kalimantan Selatan, 98 jiwa/km2, 8) Sumatera Selatan 66 jiwa $/ \mathrm{km}^{2}$.

Sedangkan untuk delapan kota besar di Indonesia berdasarkan sampel lokasi dan data BPS, yang merupakan kota terpadat adalah 1) Kota Bandung, 14.451 jiwa/km2 , wilayah terpadat di Kota Bandung terdapat di a)Kecamatan Bandung Kulon, b) Kecamatan Batununggal, c) Kecamatan Kioro Condong, adapun kota terpadat berikutnya adalah 2) Kota Yogyakarta, $11.941 \mathrm{jiwa} / \mathrm{km} 2$, wilayah terpadat di Kota Yogyakarta terdapat di a)kecamatan Gondomanan, b)kecamatan Wirobrajan dan c) kecamatan Gondokusuman, kemudian kota terpadat ketiga adalah 3) Kota Banjarmasin, 8.686 jiwa/km2, Kota Banjarmasin sebagai ibukota propinsi mempunyai luas wilayah terkecil dari kabupaten/kota di Kalsel yakni hanya 72,67 kilometer persegi, disisi lain, jumlah penduduknya tertinggi yang menempatkan Banjarmasin menjadi wilayah terpadat di Kalimantan Selatan, Kota terpadat berikutnya adalah 4) Surabaya, 8.475 jiwa/km2, wilayah terpadat di kota Surabaya II berada di a) kecamatan Tegal Sari, b) Kecamatan Genteng, c) Kecamatan Bubutan, Kota terpadat berikutnya adalah 5) Medan, 7.957 jiwa/km2, wilayah terpadat di Kota Medan berada di a)Kecamatan Medan Perjuangan, b) Kecamatan Medan Area dan C) Kecamatan Medan Maimun, Kemudian kota terpadat berikutnya adalah 6) Makassar, 7.620 jiwa/km2, 7) Semarang, 4.158 jiwa/km2, terakhir adalah 8) Palembang, 3.885 jiwa $/ \mathrm{km}^{2}$.

Tingginya kepadatan penduduk membawa akibat terhadap kondisi lingkungan pemukiman di sekitar kita, antara lain terciptanya kantong-kantong pemukiman ilegal yang akhirnya menjadi pemukiman kumuh; berkurangnya ruang publik karena okupasi ilegal; termasuk adanya kerawanan sosial.

Adapun data sosial ekonomi menunjukkan pendapatan perkapita dan pertumbuhan ekonomi di lokasi sampel penelitian (provinsi) menunjukkan bahwa 1)Provinsi Sumatera Selatan mempunyai pendapatan perkapita tertinggi yaitu sebesar Rp.18,72 juta dan dengan laju pertumbuhan ekonomi sebesar 5,10\%, kemudian 2) Jawa Timur dengan pendapatan perkapita sebesar Rp.16,75 juta dan dengan laju pertumbuhan ekonomi sebesar 5,90 \%, 3) Sumatera Utara dengan pendapatan perkapita sebesar Rp.16,40 juta dan dengan laju pertumbuhan ekonomi 
sebesar 6,39 \%, selanjutnya 4)Jawa Barat sebesar Rp.14,72 juta dengan pertumbuhan ekonomi $5,83 \%$, 5) Kalimantan Selatan sebesar Rp.13,20 juta dengan pertumbuhan ekonomi 6,23 \%, 6) Jawa Tengah sebesar Rp.11,18 juta dengan pertumbuhan ekonomi 5,46 \%, 7) DI Yogyakarta sebesar Rp. 10,98 juta dengan pertumbuhan ekonomi 5,02 \%, dan 8) Sulawesi Selatan sebesar Rp.10,90 juta dengan pertumbuhan ekonomi 7,78\%,

Dengan melihat wilayah padat di perkotaan sample dengan pertumbuhan ekonomi nya, maka terhadap daerah-daerah padat tersebut diperlukan suatu alternatif model pembangunan wilayah perkotaan tanpa pembebasan tanah yaitu dengan cara Konsolidasi Tanah. Melalui konsolidasi tanah diharapkan akan dapat mengatasi berbagai kelemahan model pembangunan konvensional seperti pembebasan tanah, dalam upaya pengadaan tanah untuk kepentingan prasarana umum dan fasilitas-fasilitas lingkungan lainnya. Konsep konsolidasi tanah dapat menjadi solusi menata ruang agar menjadi lebih baik, konsep ini menekankan pada pentingnya pelibatan semua pemangku kepentingan dalam mengembangkan lahan agar lebih tertata dengan prinsip keadilan, keterbukaan, kebersamaan dan proporsional. Konsep konsolidasi tanah berupaya mengakomodir hal tersebut, dimana masyarakat yang terlibat langsung sebagai perencana sekaligus eksekutor dan Pemerintah hanya berperan sebagai fasilitator serta regulator. Selain itu, konsep ini menekankan pada prinsip membangun bukan menggusur dan diharapkan masyarakat dapat berperan dalam memberikan sumbangan (tanahred) untuk pembangunan, imbuhnya.

Dengan adanya konsolidasi tanah akan ditumbuhkan peran serta masyarakat dalam membangun wilayah kotanya, karena dalam setiap tahap pelaksanaannya tetap melibatkan masyarakat, dalam hal ini pemilik tanah atau yang menguasai tanah. Disini masyarakat memiliki hak untuk merencanakan, membangunan, dan melakukan pengendalian sendiri tanpa campur tangan dari Pemerintah. Namun, dalam menentukan ruang yang akan digunakan harus sesuai dengan Rencana Tata Ruang (RTR) yang berlaku di kawasan tersebut.

Konsolidasi tanah harus merupakan kerelaan masyarakat untuk menyumbangkan tanahnya bagi kepentingan bersama. ${ }^{9}$ Melalui konsolidasi akan didapatkan hasil tatanan penguasaan, pemilikan, penggunaan, serta pemanfaatan tanah yang tertib dan teratur.

Konsolidasi Tanah dapat dilakukan melalui cara pembangunan :

a) Konsolidasi tanah horizontal ke horizontal

b) Konsolidasi tanah horizontal ke vertikal

c) Konsolidasi tanah vertikal ke vertikal

Namun sangat disayangkan Konsolidasi tanah kurang diminati oleh masyarakat, padahal konsolidasi tanah sangat bermanfaat bagi masyarakat bila diimplementasikan dengan baik.

\section{Penyelenggaraan Konsolidasi Tanah Perkotaan yang telah dilaksanakan di lokasi sampel penelitian}

Pelaksanaan konsolidasi tanah yang dilaksanakan di Sampel Kota Penelitian, sebagian besar di laksanakan untuk perumahan dan dibiayai oleh Dipa BPN-RI yang bersumber dari

\footnotetext{
9 Yuswanda A Tumenggung, Deputi Pengaturan dan Penataan Pertanahan Badan Pertanahan Nasional, Media Indonesia, Jakarta.
} 
APBN dan swadaya masyarakat melai PNBP . Dari 8 kota sampel, ada 2 kota provinsi yang belum pernah dilaksanakan konsolidasi tanah yaitu Yogyakarta dan Surabaya.

Seperti telah disebutkan di atas bahwa konsolidasi tanah adalah kebijakan pertanahan mengenai penataan kembali penguasaan dan penggunaan tanah yang bertujuan untuk meningkatkan kualitas lingkungan hidup/pemeliharaan sumber daya alam, untuk bisa dimanfaatkan dan digunakan secara optimal dengan melibatkan partisipasi masyarakat secara langsung. Namun model konsolidasi tanah yang banyak ditemukan mengalami perkembangan dimana sifatnya menjadi semacam pengkaplingan dan disisi lain untuk mengatasi tanah-tanah yang bermasalah serta untuk peremajaan kota.

Hal ini peneliti temukan pada Konsolidasi Tanah Perkotaan Kampung Teladan, Kelurahan Selabranti, Kec Seberang Ulu di Kota Palembang yang merupakan penyelesaian sengketa antara Yayasan Muhammaddiyah dengan masyarakat yang telah mengokupasi tanah tersebut sebagai tempat pemukman, melalui konsolidasi tanah perkotaan pada tahun 1999 .

Konsolidasi Tanah Perkotaan di Kota Semarang pelaksanaannya sebagian besar merupakan pengkaplingan tanah untuk permukiman (rumah tinggal) yang semula dimiliki/dikuasai oleh beberapa orang saja kemudian dikapling untuk perumahan yang luasannya dengan memperhatikan ketentuan dalam Keputusan Gubernur KDH Tk. I Jawa Tengah No. 11/1998 tanggal 1-8-1998 tentang Pedoman Teknis Perencanaan Perpetakan dan Perda No. 11/2004 tanggal 1-8-2004 tentang Garis Sempadan.

Sedangkan konsolidasi tanah di Kota Banjarmasin dilaksanakan dengan sasaran untuk penataan pemukiman kumuh. Sehingga dapat dikatakan model kebijakan Konsolidasi tanah dapat dikembangkan menjadi :

a) Penataan tanah untuk pemukiman (melalui pengkaplingan tanah untuk pemukiman)/ Penataan Kawasan Lingkungan Siap Bangun

b) Penataan tanah untuk penyelesaian sengketa tanah/bekas konflik/bencana.

c) Peremajaan Kota

d) Pengembangan Wilayah

e) Penataan tanah pertanian skala kecil untuk optimalisasi pengusahaannya

f) Pemukiman Kembali

Jika dikaitkan dengan ketentuan dalam Peraturan Kepala BPN Nomor 4 tahun 1991 tentang Konsolidasi Tana, maka pengembangan model kebijakan di atas dimungkinkan karena tujuan Konsolidasi Tanah adalah untuk mencapai pemanfaatan tanah secara optimal melalui peningkatan efisiensi dan produktifitas penggunaan tanah. Sedangkan sasaran Konsolidasi Tanah adalah terwujudnya suatu tatanan penguasaan dan penggunaan tanah yang tertib dan teratur.

\section{Landasan hukum pelaksanaan konsolidasi tanah Vertikal di lokasi sampel penelitian}

Sampai saat ini belum ada konsolidasi tanah secara vertikal di kota sampel penelitian, yang ditemukan semuanya merupakan konsolidasi tanah horizontal. Konsolidasi tanah horizontal yang dilaksanakan selama ini menggunakan ketentuan Peraturan Kepala Badan Pertanahan Nasional Nomor. 4 Tahun 1991tentang Konsolidasi Tanah. 
Dalam ketentuan umum Peraturan tersebut di atas disebutkan dalam pasal 1 bahwa yang dimaksud dengan :

1. Konsolidasi Tanah adalah kebijakan pertanahan mengenai penataan kembali penguasaan dan penggunaan tanah serta usaha pengadaan tanah untuk kepentingan pembangunan, untuk meningkatkan kualitas lingkungan dan pemeliharaan sumber daya alam denga melibatkan partisipasi aktif masyarakat.

2. Peserta konsolidasi tanah adalah pemegang hak atas tanah atau penggarap tanah negara obyek Konsolidasi Tanah.

3. Tanah obyek Konsolidasi Tanah adalah tanah negara non pertanian dan atau tanah hak, di wilayah perkotaan atau pedesaan yang ditegaskan oleh Kepala Badan Pertanahan Nasional untuk dikonsolidasi.

4. Sumbangan tanah untuk pembangunan adalah bagian dari obyek Konsolidasi Tanah yang disediakan untuk pembangunan prasarana jalan dan fasilitas umum lainnya, serta untuk Tanah Pengganti biaya Pelaksanaan.

5. Tanah pengganti Biaya Pelaksanaan adalah bagian dari Sumbangan Tanah untuk Pembangunan yang diserahkan kepada pihak ketiga dengan pembayaran kompensasi berupa uang yang dipergunakan untuk pembiayaan kegiatan pelaksanaan konsolidasi tanah sesuai dengan Daftar Rencana Kegiatan Konsolidasi Tanah (DRKK).

6. Surat ijin menggunakan Tanah (SIMT) adalah Surat Ijin Menggunakan Tanah Pengganti Biaya Pelaksanaan sebagai tersebut angka 4 yang di keluarkan oleh Kepala KantorPertanahan Kabupaten/Kotamadya.

Ada beberapa pasal yang penting untuk menjadi perhatian, antara lain dalam Pasal 4 disebutkan bahwa ;

(1) Lokasi konsolidasi Tanah ditetapkan oleh Bupati/Walikotamadya Kepala Daerah Tingkat II dengan mengacu kepada Rencana Tata Ruang dan Rencana Pembangunan Daerah.

(2) Konsolidasi Tanah dapat dilaksanakan apabila sekurang-kurangnya 85 persen dari pemilik tanah yg luas tanahnya meliputi sekurang-kurangnya 85 persen dari luas seluruh areal tanah yg akan dikonsolidasi, menyatakan persetujuannya.

Selanjutnya Pasal 6 mengenai Sumbangan Tanah Untuk Pembangunan menyebutkan bahwa :

1. Dalam rangka pelaksanaan penataan penguasaan dan penggunaan tanah obyek Konsolidasi Tanah, para peserta menyerahkan sebagian tanahnya sebagai sumbangan Tanah untuk Pembangunan yg akan dipergunakan untuk pembangunan prasarana jalandan fasilitas umum lainnya dan pembiayaan pelaksanaan Konsolidasi Tanah.

2. Besarnya sumbangan Tanah untuk Pembangunan sebagaimana dimaksud pada ayat (1)ditetapkan berdasarkan kesepakatan bersama peserta Konsolidasi Tanah dengan mengacu kepada Rencana Tata Ruang Daerah.

3. Peserta yang persil tanahnya terlalu kecil sehingga tidak mungkin menyerahkan sebagian tanahnya sebagai sumbangan tanah untuk pembangunan dapat mengganti sumbangan tersebut dengan uang atau bentuk lainnya yg disetujui bersama oleh para peserta Konsolidasi Tanah. 
Mengenai Pembiayaan diatur dalam Pasal 7, bahwa :

(1) Pada azasnya pembiayaan Konsolidasi Tanah ditanggung para peserta Konsolidasi Tanah, melalui sumbangan berupa tanah dan atau berupa uang maupun bentuk bentuk sumbangan lainnya sebagaimana dimaksud pasal 6.

(2) Sumbangan berupa tanah sebagaimana dimaksud pada ayat (1) oleh peserta Konsolidasi tanahdilepaskan hak atas tanahnya atau garapannya kepada negara dihadapan Kepala Kantor Pertanahan setempat.

(3) Tanah pengganti biaya pelaksanaan, yang merupakan bagian dari sumbangan tanah untuk pembangunan yang diperuntukan bagi pembiayaan pelaksanaan Konsolidasi Tanah diserahkan penggunaannya kepada peserta yang memiliki persil tanah terlalu kecil atau kepada pihak lain dengan pembayaran kompensasi berupa uang yang jumlahnya disetujui oleh para peserta Konsolidasi Tanah.

(4) Penyerahan penggunaan sebagaimana dimaksud ayat (3) dilakukan oleh Kepala Kantor Pertanahan setempat dengan menerbitkan Surat ijin menggunakan Tanah (SIMT) yang selanjutnya menjadi dasar pemberian hak atas tanah kepada yang bersangkutan.

Yang banyak ditemukan dan berkembang adalah pembangunan perumahan rumah susun yang terdiri dari rumah susun milik maupun rumah susun sewa. Dalam pembangunan rumah susun, didasarkan pada Undang-Undang Nomor 16 tahun 1985 tentang Rumah Susun dan peraturan pelaksanaannya PP Nomor 4 tahun 1988.

Konsiderans menimbang Undang-Undang Rumah Susun menyebutkan bahwa dalam rangka peningkatan daya guna dan hasil guna tanah bagi pembangunan perumahan dan untuk lebih meningkatkan kualitas lingkungan pemukiman terutama di daerah-daerah yang berpenduduk

padat tetapi hanya tersedia luas tanah yang terbatas, dirasakan perlu untuk membangun perumahan dengan sistem lebih dari satu lantai, yang dibagi atas bagian-bagian yang dimiliki bersama dan satuansatuan yang masing-masing dapat dimiliki secara terpisah untuk dihuni, dengan memperhatikan faktor sosial budaya yang hidup dalam masyarakat;

Selanjutnya dalam Ketentuan Umum disebutkan yang dimaksud dengan :

1. "Rumah Susun" adalah bangunan gedung bertingkat yang dibangun dalam suatu lingkungan, yang terbagi dalam bagian-bagian yang distrukturkan secara fungsional dalam arah horizontal maupun vertikal dan merupakan satuan-satuan yang masing-masing dapat dimiliki dan digunakan secara terpisah, terutama untuk tempat hunian, yang dilengkapi dengan bagian-bersama, benda-bersama dan tanahbersama.

2. "Satuan rumah susun" adalah rumah susun yang tujuan peruntukan utamanya digunakan secara terpisah sebagai tempat hunian, yang mempunyai sarana penghubung ke jalan umum.

3. "Lingkungan" adalah sebidang tanah dengan batas-batas yang jelas yang di atasnya dibangun rumah susun termasuk prasarana dan fasifitasnya, yang secara keseluruhan merupakan kesatuan tempat pemukiman.

4. "Bagian-bersama" adalah bagian rumah susun yang dimiliki secara tidak terpisah untuk pemakaian bersama dalam kesatuan fungsi dengan satuan-satuan rumah susun.

5. "Benda-bersama" adalah benda yang bukan merupakan bagian rumah susun, tetapi yang dimiliki bersama secara tidak terpisah untuk pemakaian bersama. 
6. "Tanah-bersama" adalah sebidang tanah yang digunakan atas dasar hak bersama secara tidak terpisah yang di atasnya berdiri rumah susun dan ditetapkan batasnya dalam persyaratan izin bangunan.

Kemudian dalam Pasal 4 mengenai Pengaturan dan Pembinaan Rumah Susun disebutkan bahwa

(1) Pemerintah melakukan pengaturan dan pembinaan rumah susun.

(2) Pemerintah dapat menyerahkan kepada Pemerintah Daerah untuk melaksanakan sebagian urusan pengaturan dan pembinaan rumah susun sebagaimana dimaksud dalam ayat (1).

(3) Pelaksanaan ketentuan sebagaimana dimaksud dalam ayat (2) diatur dengan Peraturan Pemerintah.

Peraturan Pemerintah Nomor 4 tahun 1988 tentang Rumah Susun menyebutkan dalam pasal 1 bahwa :

1. Penyelenggara pembangunan adalah Badan Usaha Milik Negara atauDaerah, Koperasi, dan Badan Usaha Milik Swasta yang bergerak dalam bidang pembangunan rumah susun, serta swadaya masyarakat.

2. Akta pemisahan adalah tanda bukti pemisahan rumah susun atas satuan-satuan rumah susun, bagian bersama, benda bersama dan tanah bersama dengan pertelaan yang jelas dalam bentuk gambar, uraian dan batas-batasnya dalam arah vertikal dan horizontal yang mengandung nilai perbandingan proporsional.

3. Pemerintah Daerah adalah Pemerintah Daerah Tingkat II Kabupaten/ Kotamadya dan Pemerintah Daerah Tingkat I Daerah Khusus lbukota Jakarta.

4. Kesatuan sistem pembangunan adalah pembangunan yang dilaksanakan pada tanah bersarna dengan penggunaan dan pemanfaatan yang berbeda-beda baik untuk hunian maupun bukan hunian secara mandiri maupun terpadu berdasarkan perencanaan lingkungan atau perencanaan bangunan yang merupakan satu kesatuan.

5. Persyaratan teknis adalah persyaratan mengenai struktur bangunan, keamanan, keselamatan, kesehatan, kenyamanan, dan lain-lain yang berhubungan dengan rancang bangun, termasuk kelengkapan prasarana dan fasilitas lingkungan, yang diatur dengan peraturan perundang undangan serta disesuaikan dengan kebutuhan dan perkembangan.

6. Persyaratan administratif adalah persyaratan mengenai perizinan usaha dari perusahaan pembangunan perumahan, izin lokasi dan/atau peruntukannya perizinan mendirikan bangunan (IMB), serta izin layak huni yang diatur dengan peraturan perundangundangan dan disesuaikan dengan kebutuhan dan perkembangan.

7. Nilai perbandingan proporsional adalah angka yang menunjukkan perbandingan antara satuan rumah susun terhadap hak atas bagian bersama, benda bersama, dan tanah bersama, dihitung berdasarkan luas atau nilai satuan rumah susun yang bersangkutan terhadap jumlah luas bangunan atau nilai rumah susun secara keseluruhan pada waktu penyelenggara pembangunan untuk pertama kali memperhitungkan biaya pembangunannya secara keseluruhan untuk menentukan harga jualnya.

Yang menjadi permasalahan dalam pembangunan perumahan secara vertikal salah satunya adalah belum semua daerah memiliki Peraturan Daerah mengenai Rumah Susun. Perda Rumah Susun diperlukan untuk pembangunan rumah susun sebagaimana disyaratkan dalam PP No.4 tahun 1988. Oleh karenanya bagi daerah yang belum memiliki Peraturan Daerah Rumah Susun membuat kebijakan rumah susun yang dituangkan dalam Surat Keputusan Walikota atau 
semacamnya. Dalam tabel di bawah ini, ditampilkan model pembangunan perumahan secara vertikal yang mendekati konsep konsolidasi tanah secara vertikal.

Tabel 44. Pelaksanaan pembangunan perumahan secara vertikal di Lokasi Sampel Penelitian

\begin{tabular}{|c|c|c|c|c|c|c|c|}
\hline No & Kota & Lokasi & Inisiator & Obyek & Subyek & Tahun & Keterangan \\
\hline 1 & Medan & $\begin{array}{l}\text { kampung Aur, } \\
\text { Kelurahan Aur, } \\
\text { Kecamatan } \\
\text { Medan Maimun }\end{array}$ & $\begin{array}{l}\text { Kementrian } \\
\text { Perumahan } \\
\text { Rakyat }\end{array}$ & $\begin{array}{l}\text { tanah grant sultan } \\
\text { yang dikuasai oleh } \\
\text { masyarakat selama } \\
\text { puluhan tahun daerah } \\
\text { kumuh dengan padat } \\
\text { penduduk }\end{array}$ & $\begin{array}{l}\text { masyarakat } \\
\text { setempat }\end{array}$ & 2009 & $\begin{array}{l}\text { tidak ditanggapi secara } \\
\text { positif oleh masyarakat } \\
\text { setempat, mereka lebih } \\
\text { memilih untuk diberikan } \\
\text { ganti rugi terhadap tanahnya }\end{array}$ \\
\hline \multirow[t]{2}{*}{2} & \multirow[t]{2}{*}{ Palembang } & $\begin{array}{l}\text { Simpang Sungki, } \\
\text { Kertapati }\end{array}$ & $\begin{array}{l}\text { Menpera dan } \\
\text { PT KAI }\end{array}$ & $\begin{array}{l}\text { tanah asset PT KAI } \\
\text { diduduki masyarakat } \\
\text { selama bertahun-tahun } \\
\text { dan saat ini sudah } \\
\text { merupakan pemukiman } \\
\text { padat }\end{array}$ & $\begin{array}{l}\text { masyarakat } \\
\text { setempat }\end{array}$ & 2009 & $\begin{array}{l}\text { Saat ini ditangani oleh } \\
\text { Menpera dan PT KAI Pusat } \\
\text { namun belum diperoleh } \\
\text { kesepakatan antara } \\
\text { masyarakat, PT KAI dan } \\
\text { Menpera }\end{array}$ \\
\hline & & $\begin{array}{l}\text { Rusun Milik } 24 \text { llir } \\
\text { Palembang dan } \\
26 \text { llir Palembang } \\
4 \text { lantai. }\end{array}$ & $\begin{array}{l}\text { Menpera dan } \\
\text { Pemerintah } \\
\text { Kota } \\
\text { Palembang }\end{array}$ & $\begin{array}{lr}\text { Tanah } & \text { nasyarakat } \\
\text { korban } & \text { kebakaran } \\
\text { yang } & \text { merupakan } \\
\text { pemukiman } & \text { padat dan } \\
\text { dihuni } & \text { melebihi } \\
\text { kapasitas } & \text { yang } \\
\text { menyebabkan } & \\
\text { kekumuhan } & \end{array}$ & $\begin{array}{l}\text { masyarakat } \\
\text { setempat }\end{array}$ & 1989 & $\begin{array}{l}\text { Pemkot Palembang } \\
\text { merencanakan peremajaan } \\
\text { Rusun yang semula } 4 \text { lantai, } \\
\text { menjadi } 12 \text { lantai, karena } \\
\text { kondisi bangunan sudah tua } \\
\text { dan kumuh. warga resah } \\
\text { takut kehilangan tempat } \\
\text { tinggal, dan kelangsungan } \\
\text { kehidupan keluarga yang } \\
\text { tidak mampu. }\end{array}$ \\
\hline 3 & Bandung & $\begin{array}{l}\text { Kelurahan } \\
\text { Cibabat, } \\
\text { Kecamatan } \\
\text { Cimahi Utara }\end{array}$ & $\begin{array}{l}\text { Pemerintah } \\
\text { Kota Cimahi }\end{array}$ & $\begin{array}{l}\text { tanah hak milik adat } \\
\text { merupakan daerah } \\
\text { kumuh dengan padat } \\
\text { penduduk }\end{array}$ & $\begin{array}{l}\text { masyarakat } \\
\text { setempat }\end{array}$ & 2009 & $\begin{array}{l}\text { Belum ada kesepakatan } \\
\text { terhadap pembagian tanah } \\
\text { setelah dilaksanakan } \\
\text { Konsolidasi Tanah }\end{array}$ \\
\hline 4 & Semarang & $\begin{array}{l}\text { Pekunden } \\
\text { Semarang } \\
\text { Tengah }\end{array}$ & $\begin{array}{l}\text { Pemerintah } \\
\text { Kota } \\
\text { Semarang }\end{array}$ & $\begin{array}{l}\text { Tanah pemda dan } \\
\text { masyarakat }\end{array}$ & $\begin{array}{l}\text { Masyarakat } \\
\text { setempat } \\
\text { dan Pemda }\end{array}$ & 1991 & $\begin{array}{l}50 \text { unit status hak milik, } \\
38 \text { unit status sewa ke } \\
\text { Pemkot. } \\
\text { Proses Sertifikat dari } 50 \\
\text { rumah sampai saat ini } \\
\text { belum selesai. }\end{array}$ \\
\hline \multirow[t]{2}{*}{5} & Surabaya & $\begin{array}{l}\text { Kp.Sumbo, } \\
\text { Kel.Simolawang } \\
\text { Kec. Simokerto }\end{array}$ & $\begin{array}{l}\text { Pemerintah } \\
\text { Kota } \\
\text { Surabaya } \\
\text { dan Johan } \\
\text { Silaas }\end{array}$ & $\begin{array}{l}\text { Tanah Pemerintah } \\
\text { Kota }\end{array}$ & $\begin{array}{l}\text { orang } \\
\text { madura } \\
\text { pengelola } \\
\text { kandang sapi } \\
\text { dan pegawai } \\
\text { Dinas } \\
\text { Kebersihan }\end{array}$ & 1989 & $\begin{array}{l}\text { semula adalah kandang sapi } \\
\text { yang dikelola oleh orang } \\
\text { madura dan } \\
\text { pegawai Dinas Kebersihan } \\
\text { karena kumuh akhirnya } \\
\text { dibangun rusun dengan } \\
\text { prioritas orang-orang yang } \\
\text { semula menetap di daerah } \\
\text { tersebut }\end{array}$ \\
\hline & & Bangun rejo & $\begin{array}{l}\text { Pemerintah } \\
\text { Kota } \\
\text { Surabaya }\end{array}$ & $\begin{array}{l}\text { Tanah Pemerintah } \\
\text { Kota }\end{array}$ & $\begin{array}{l}\text { masyarakat } \\
\text { setempat }\end{array}$ & - & $\begin{array}{l}\text { kumuh akhirnya dibangun } \\
\text { rusun dengan prioritas yang } \\
\text { bertempat tinggal }\end{array}$ \\
\hline 6 & Yogyakarta & $\begin{array}{l}\text { Kel. Tegal } \\
\text { Panggung, Kec. } \\
\text { jetis }\end{array}$ & $\begin{array}{l}\text { Pemerintah } \\
\text { Kota } \\
\text { Yogyakarta }\end{array}$ & $\begin{array}{l}\text { Tanah Pemerintah } \\
\text { Kota }\end{array}$ & $\begin{array}{l}10 \mathrm{KK} \\
\text { penghuni } \\
\text { asal }\end{array}$ & - & $\begin{array}{l}\text { konsolidasi tanah dengan } \\
\text { pendekatan pembangunan } \\
\text { perumahan secara vertikal } \\
\text { belum ada }\end{array}$ \\
\hline 7 & Banjarmasin & - & - & - & - & & - \\
\hline 8 & Makassar & - & - & - & - & & - \\
\hline
\end{tabular}

Sumber: BPN Kantor Pertanahan 2009, diolah 


\section{a) Kota Medan.}

Keinginan untuk melaksanakan Konsolidasi Tanah Perkotaan secara vertikal di Kota Medan yang diinisiasi oleh Kementrian Perumahan Rakyat pada tahun 2009 di kampung Aur, Kelurahan Aur, Kecamatan Medan Maimun, lokasinya merupakan daerah kumuh dengan padat penduduk namun tidak ditanggapi secara positif oleh masyarakat setempat, mereka lebih memilih untuk diberikan ganti rugi terhadap tanahnya. Tanah tersebut statusnya adalah tanah grant sultan yang sudah dikuasai oleh masyarakat selama puluhan tahun.

Menumbuhkan kesadaran kepada masyarakat untuk merelakan tanahnya agar dapat dijadikan obyek Konsolidasi tanah secara Vertikal tidaklah mudah. Oleh karena itu jangka waktu sosialisasi perlu alokasi waktu yang cukup lama. Adapun alasan penduduk Kp. Aur menolak untuk dilaksanakan Konsolidasi Tanah vertikal, antara lain :

- Kuatir jika terjadi gempa

- Harus menggunakan tangga sedangkan masyarakatnya banyak yang sudah tua

- Takut jika terjadi kebakaran

- Membahayakan anak-anak jika berada dibangunan bertingkat

Berbagai alasan tersebut di atas dapat dipahami mengingat masyarakat belum terbiasa untuk tinggal di perumahan secara vertikal.

Sebagai sesuatu yang baru bagi masyarakat, cukup banyak permasalahan yang menyangkut pengelolaan rumah susun. Permasalahan penghunian datang dari kenyataan bahwa menghuni rumah susun masih dirasakan sebagai bentuk budaya baru yang memerlukan waktu penyesuaian. Rumah susun terdiri dari beberapa lantai hunian, merupakan bentuk perubahan hidup yang biasa melekat dengan tanah, menjadi tidak memiliki tanah untuk sekedar bercocok tanam. Kendala lain adalah masalah penghunian, pada awal penghunian sudah diadakan seleksi sesuai dengan target sasaran, yaitu masyarakat yang berpenghasilan rendah. Namun dalam perjalanannya, banyak penghuni yang memperjual-belikan hak penghuniannya kepada orangorang yang tidak berhak.

\section{b) Kota Palembang}

Konsolidasi Tanah Perkotaan dengan pendekatan pembangunan secara vertical direncanakan di lokasi Simpang Sungki, Kertapati, tanah ini merupakan asset PT KAI dekat dengan Setasiun Kereta Kertapati yang telah diduduki oleh masyarakat sebagai tempat pemukiman selama bertahun-tahun dan saat ini sudah merupakan daerah pemukiman padat. Direncanaakan akan ditata kembali dengan konsep konsolidasi vertikal namun belum diperoleh kesepakatan dari berbagai pihak terkait, dan saat ini ditangani oleh Menpera dan PT KAI Pusat namun belum diperoleh kesepakatan antara masyarakat, PT KAI dan Menpera.

Rusun Milik 24 dan 26 Ilir Palembang semula merupakan daerah pemukiman padat korban kebakaran yang dihuni oleh masyarakat dengan melebihi kapasitas yang menyebabkan kekumuhan. Menpera dan Pemerintah Kota Palembang tahun 1998 berinisiatif untuk membangun kawasan sersebut menjadi rumah susun milik untuk memenuhi kebutuhan masyarakat korban kebakaran dan masyarakat sekitarnya yang waktu itu cupup padat dan kumuh, diharapkan dapat ditampung dalam rumah susun tersebut. 
Pembangunan rusun dibangun 4 lantai dan pelaksanaan pembangunannya diserahkan kepada Perum Perumnas. Proses pembangunan rusun dilaksanakan dengan tahapan pemberian ganti-rugi asset yang dimiliki oleh masyarakat korban kebakaran dan sekitarnya, dengan nilai kompensasi yang ditaksir oleh Panitia 9 (Panitia Pembebasan Tanah).

Masyarakat yang mendapatkan ganti-rugi tersebut diberikan prioritas untuk memperoleh kembali Rusun setelah dibangun dengan cara membeli baik secara chas maupun angsuran/kredit, namun tidak semua masyarakat yang mendapatkan ganti-rugi tersebut mengambil kembali rusun tersebut, karena sebagian membeli tanah atau rumah di lokasi lain bukan rumah susun; Pembangunan rusun dibangun 4 lantai sebanyak 61 tower dengan berbagai type yaitu type 18 sebanyak 1634 unit, type 36 sebanyak 976 unit dan type 54 sebanyak 954 unit dengan jumlah 3564 unit.

Menurut Kabid Renstra Bappeda, Bpk. Gunawan dan tanggapan Direktur Perum Perumnas Kota Palembang Ir. Arif Sutopo, kebutuhan akan hunian layak bagi warga berpenghasilan menengah ke bawah di Kota Palembang sudah sangat mendesak, saat ini sedang merencanakan peremajaan Rumah Susun 24 dan 26 Ilir Palembang yang semula 4 lantai direncanakan ditingkatkan menjadi 12 lantai, karena bangunannya sudah tua dan kondisinya sudah kumuh, di samping itu juga merencanakan untuk membangun rusun di lokasi lainnya.

Pada saat ini sedang diupayakan penghutungan-penghitungan, identifikasi data hunian dan penghuni rusun, namun masyarakat penghuni sebagian besar sudah kurang percaya dan sebagian lagi sudah apatis terhadap kebijakan peremajaan tersebut, yang penting menurut mereka dapat memperoleh ganti rugi yang cukup dan memadai.

Pengembangan konsolidasi tanah vertical menurut Ketua DPU Kota Palembang maupun Kepala Perum Perumnas sangat dimungkinkan untuk dikembangkan di Kota Palembang, namun diperlukan perencanaan yang matang dan persetujuan dari pusat.

\section{c) Kota Bandung}

Konsolidasi Tanah Perkotaan dengan pendekatan pembangunan secara vertikal, pada tahun 2009 yang diinisiasi oleh Pemerintah Kota Cimahi di RW 18 , Kelurahan Cibabat, Kecamatan Cimahi Utara dimana lokasinya merupakan daerah kumuh dengan padat penduduk. Luas wilayah RW $18 \pm 65.505 \mathrm{M}^{2}$, dengan bidang tanah terkecil seluas $\pm 28 \mathrm{M}^{2}$, sebanyak 415 bidang. Tanah tersebut statusnya adalah tanah hak milik adat, NJOP terendah Rp. 40.000,- dan NJOP tertinggi Rp. 537.000,-. Namun pelaksanaan Konsolidasi Tanah Vertikal tersebut tidak dapat terlaksana, kemungkinan permasalahan di lapangan yaitu :

a. Nilai tanah sebelum dilaksanakan Konsolidasi Tanah dengan setelah dilaksanakan Konsolidasi Tanah;

b. Perubahan pola huni masyarakat horizontal ke vertikal;

c. Penanganan terhadap tempat tinggal sementara para peserta Konsolidasi Tanah selama dilaksanakan pembangunan;

d. Penanganan terhadap penduduk yang tidak bersedia ikut dalam kegiatan Konsolidasi Tanah;

e. Belum ada kesepakatan terhadap pembagian tanah setelah dilaksanakan Konsolidasi Tanah;

f. Sumber anggaran untuk kegiatan Konsolidasi Tanah. 


\section{d) Kota Semarang}

Konsolidasi Tanah Perkotaan dengan pendekatan pembangunan secara vertical di Kota Semarang belum pernah dilaksanakan, namun pembangunan rumah susun sederhana (rusuna) sebagai upaya mempercepat pemenuhan kebutuhan perumahan bagi masyarakat perkotaan terutama yang berpenghasilan menengah bawah dan MBR dengan mengedepankan efisiensi penggunaan tanah sekaligus penataan permukiman di kawasan perkotaan telah dilaksanakan.

Rusun Pekunden, Semarang Tengah, Kota Semarang merupakan konsep pembangunan rusun yang mirip dengan konsep konsolidasi tanah vertikal. Pembangunan Rusun Pekunden merupakan Pelaksanaan Program Penataan Permukiman di tengah perkotaan Pemerintah Kota Semarang membangun Rumah Susun Pekunden pada tahun 1991 yang lokasinya di belakang Balai Kota Semarang dengan Sistim "Membangun Tanpa Menggusur" karena penghuninya adalah warga pemilik rumah yang terkena proyek.Pembangunan Rusun Pekunden, dimaksudkan untuk menata kembali permukiman yang sudah ada tetapi tidak layak huni ditengah perkotaan dan mayoritas penghuninya warga ekonomi lemah.

Pembangunan rusun diawali dengan kesepakatan Pemkot dengan masyarakat penghuni dengan perjanjian bahwa tanah dan bangunan masyarakat yang berdomisili di lingkungan tersebut dinilai sesuai dengan kondisi existing yang ada. Masing-masing diberikan kompensasi sesuai dengan nilai tanah dan bangunan tersebut, namun tidak diberikaan dalam bentuk uang tetapi sebagai uang muka untuk mendapatkan unit satuan atas rumah susun yang akan dibangun sesuai proporsi nilai tanah yang sudah disepakati oleh seluruh penghuni yang ada.

Hal ini diharapkan dapat meningkatkan kesejahteraan para penghuni yang sebagian besar adalah karyawan/buruh industri, sehingga mendapatkan keuntungan antara lain :

a) Warga tidak perlu mencari tempat tinggal pengganti dengan lingkungan yang masih sama

b) Dapat menikmati rumah yang layak di perkotaan sesuai dengan peghasilannya.

c) Dapat menikmati lingkungan yang dilengkapi dengan taman,;tempat bermain anak, lapangan olah raga, balai serbaguna yang dipergunakan bersama,

d) Dapat mengembangkan usaha karena di lantai dasar disiapkan untuk tempat usaha

e) Hemat biaya transportasi, dekat dengan tempat kerja.

f) Hemat waktu di perjalanan sehingga dapat meningkatkan produktivitas.

g) Dapat hidup sehat karena tiap rumah dilengkapi dengan $\mathrm{KM} / \mathrm{WC}$, dapur dan tempat jemuran sendiri walaupun type 27.

Hal ini sejalan dengan program Pemda dalam Peremajaan Pemukiman di perkotaan serta Memasyarakatkan Rumah Susun dalam Pemilihan Pemukiman di perkotaan.

Pelaksanaan Pembangunan Rusun Pekunden :

1. Dasar pelaksanaan adalah PP NO. 5/1990 tentang peremajaan permukinan kumuh ditengah perkotaan, terutama tanah milik negara; 
2. Lokasi Rusun Pekunden adalah wilayah Rt 04 dan Rt 05/Rw I Kelurahan Pekunden Kecamatan Semarang Timur (sebelum ada penataan kota);

3. Terdiri dari: 29 bangunan rumah penduduk dan 1 bangunan Musholla Al Mukhsin, yang ditenpati oleh $74 \mathrm{KK}$;

4. Survey bulan april 1991 oleh mahasiswa UNDIP yang didampingi oleh Ir.Panggardjito dari PU Cipta Karya Semarang;

5. Penyuluhan warga oleh ketua BAPPEDA Semarang;

6. Usulan warga kepada Tim Satgas Rusun Pekunden :

- Pelaksanaan pembangunan Rusun secara manusiawi/melalui pendekatan;

- Mernbangun tanpa menggusur artinya warga mendapat prioritas utama untuk menghuni rusun;

- Bangunan tidak membuat suasana kumuh baru ada kamar mandi/wc tiap rumah, tempat jemuran dan fasilitas umum yang memadai;

- Sistem tidak merugikan warga masyarakat penghuni;

- Harga sewa rusun terjangkau sesuai kemampuan;

- Selama pembangunan warga tidak diterlantarkan dan diberi biaya pondokan;

- Sarusun yang sudah lunas dapat sertifikat sarusun.

7. .Kesepakatan warga penghuni dengan Pem. Kodya Semarang tanggal 21-8-1991 :

a) Sebelum rumah dibongkar warga mendapatkan kompensasi sesuai dengan aset yang dimiliki, tetapi untuk membayar uang muka rusun yang akan ditempati;

b) Sebelum membongkar rumah, warga mendapat uang kontrak setahun dan biaya bongkar rumah .

c) Pembagian sarusun diserahkan kepada warga melalui wakil yang ditunjuk (Ny. Suatni).

d) Lantai I untuk usaha, lantai II dan III untuk pemilik rumah lama dan lantai IV untuk pengikut / penyewa / pendatang

e) Harga sarusun tiap Unit Rp 6.000.000,- ( enam juta rupiah) Type 27 ( 7,5x3,5m² = $27 \mathrm{~m}^{2}$ ) karena mendapat subsidi yang harga aslinya tiap unit $\mathrm{Rp} 9.000 .000$,- (pada tanun 1992)

untuk type 54 harga $\mathrm{Rp} 12.000 .000,-$

untuk type 81 harga Rp 18.000.000,-

Status Penghuni Rusun Pekunden :

- 50 rumah status hak milik, sudah bayar uang muka melalui uang kompensasi nilai aset yang dimiliki semula;

- 38 rumah status sewa yang besarnya Rp. 13.500,- s/d Rp.15.000,- setiap bulan langsung ke Pemkot.

- Proses Sertifikat dari 50 rumah sampai saat ini belum selesai. 
Tahapan Pelaksanaan Pembanunan Rusun Pekunden :

1. Pra pembangunan rusun :

a. Penyuluhan :

- Penyuluhan tentang rencana pembangunan rusun oleh Ketua Bappeda Kota Semarang kepada warga Pekunden, Sekayu dan Miroto yang termasuk pemukim tanah milik negara yang akan dibangun rusun;

- Penjelasan PP No. 5 tahun 1990 tentang Peremajaan Pemukiman Kumuh untuk daerah perkotaan di atas tanah milik negara;

b. Menghimpun tanggapan masyarakat yang terkena proyek;

- Kesepakatan warga setuju pembangunan rusun apabila system ganti rugi/kompensasi tidak terlalu merugikan warga, dan setelah jadi mendapatkan prioritas pertama untuk menempati;

- selama pembangunan tidak terlantar dan diberi uang untuk pemondokan;

- pembangunan tidak membuat suasana kumuh baru, mempunyai KM/WC sendiri, tempat jemuran dan fasilitas lain;

- pelaksanaan secara manusiawi dan pendekatan;

- fasilitas rusun dilengkapi mushola, aula, taman, tempat bermain dll;penempatan penghuni disesuaikan seperi sebelum dibangun rusun;

- mendapatkan sertipikat hak;

c. Pengukuran tanah dan bangunan rumah dilokasi proyek;

- pengukuran dan penggambaran rumah lama yang akan dibongkar, lengkap dengan ukuran tanah dan bangunan;

d. Sosialisasi dari Bappeda dan Tim Satgas Rusun Kota Semarang tentang penghitungan kompensasi asset tanah dan bangunan lama dan kesepakatan warga;

- kompensasi tanah

- bangunan permanen

- bangunan semi permanen

- bangunan non permanen

- biaya kontrak sementara

- biaya pembongkaran rumah

: Rp. $50.000,-/$ pemilik;

- uang kompensasi tidak dibayarkan secara tunai, namun pemilik rumah dianggap sudah bayar uang muka dengan uang kompensasi yang diperolehnya secara langsung;

- jumlah kompensasi terkecil Rp. 500.000,- dan terbesar Rp. 17.440.500,-

- $\quad$ sertifikat tidak diperoleh secara langsung/memakan waktu.

e. Penandatanganan gambar rumah/tanah dan surat kesepakatan warga lokasi proyek;

- sebelum dibongkar sudah mendapatkan kompensasi sesuai dengan asset yang dimiliki (luas tanah, bangunan dan fasilitas yang dimiliki);

- sebelum membongkar rumah sudah mendapatkan biaya kontrakminimal satu tahun dan 
biaya pembongkaran rumah;

- penyewa/pengontrak mendapatkan biaya sendiri;

- tenggang waktu pembongkaran minimal satu bulan.

f. Jadwal pelaksanaan pembongkaran rumah/pindah sementara.

2. Pembangunan rusun :

a. Pemberitahuan gambar bangunan;

- rusun dibangun 5 blok : A, B, C, D, E. terdiri dari 108 unit rusun;

- tempat usaha dibangun di lantai dasar;

- rencana bangunan ukuran standar setiap petak $=7,5 \mathrm{~m} \mathrm{x} \mathrm{3,5} \mathrm{m}=27 \mathrm{~m}^{2}$ dilengkapi dengan KM/WC, dengan harga sarusun tiap Unit Rp 6.000.000,- $\quad$ (enam juta rupiah) karena mendapat subsidi yang harga aslinya tiap unit Rp 9.000.000,- (pada tanun 1992);

- untuk type 54 harga Rp 12.000.000,-

- untuk type 81 harga Rp 18.000.000,-

- dapat dicicil paling lambat 20 tahun, dengan cicilan Rp. 40.000,-/bulan atau Rp. 1350/hari;

b. Mengajukan usulan pemanfaatan lantai dasar untuk tempat usaha kepada Pimpro dan Pemda oleh wakil warga;

- Penyuluhan tata cara tinggal di rumah susun;

- menjaga kebersihan dan ketertiban;

- mengutamakan kerukunan dan kelompok karena hidup bersama;

- pemakaian KM/WC, membuang sampah, menjemur pakaian dsb;

- perabot lama/rusak tidak dibawa ke rusun;

c. Pembagian rumah kepada warga yang berhak;

- pembagian rumah disesuaikan dengan urutan prioritas;

- untuk pemilik rumah diutamakan di lantai II, kecuali yang type 54, karena di lantai II hanya ada 2, yang lainndi lantai III dilihat dari jumlah uang kompensasi;

- ada beberapa warga yang tukar type, dari 81 ditukar 27 sebanyak 3, type 54 ditukar 27 sebanyak 2, dan type 27 ditukar 81 karena ada sisa dan mampu membayar angsuran;

- warga yang punya tempat usaha akan mendapat prioritas utama;

- pembagian rumah dan pengelolaan diserahkan kepada wkil warga;

- pengontrak diberi kesempatan untuk memiliki dengan angsuran.sewa;

- warga yang mendapatkan kompensasi mendapatkan unit rusun di lantai II;

- warga pengikut dan pengontrak mendapatkan unit rusun di lantai II dan III;

- sisanya diberikan warga sekitar yang mendesak dan belum punya rumah.

- rusun dibangun 88 unit : type $27=(73)$ unit, type $54=(10)$ unit, type $81=(5)$ unit;

- pembagian tempat telah disepakati :

○ pemilik rumah : $81=(4$ warga $), 54=(8$ warga $), 27=(23$ warga $)$;

- pengikut / pengontrak 47 warga; 
- sisa 6 unit rumah type $81=(1)$ unit dan type $27=(5)$ unit.

- pengelolaan selama satu tahun di bawah bimbingan PU Cipta Karya;

- lantai dasar akan diatur Pemda untuk usaha yang tidak mengandung resiko;

d. Peresmian rusun;

3. Pembentukan Paguyuban Perkampungan Rumah Susun :

a. Menetapkan program kerja;

b. Menyusun peraturan tata-tertib penghuni rusun;

c. Menyusun AD/ART;

Sampai saat ini dengan waktu yang hampir 19 tahun masyarakat belum mendapatkan sertipikat gratis yang sudah dijanjikan. Menurut Ketua PPRS Pekunden Ibu Hj Suatni Sutarman sedang dalam proses, dalam hal ini ditangani oleh DTKP Kota Semarang, yang menurutnya sudah diajukan ke Kantah BPN Kota Semarang, yang di klaim sejak tahun 2006 namun belum dapat menunjukkan bukti adanya permohonan masuk tersebut, dan menurut Kantah BPN Kota Semarang (Kasubsi HTPT) permohonan tersebut pernah diajukan namun hal ini belum dapat diproses dikarenakan adanya kekurangan berkas administrasi yaitu persyaratan adanya Pihak III sebagai Badan Hukum yang mengelola pembangunan rusun tersebut, hal ini belum dapat dipenuhi karena pembangunan rusun tersebut dilaksanakan dan dibiayai oleh Ditjend Ciptakarya Pusat. Menurut pihak DTKP menyatakan (Pemko) sudah menunjuk pihak ke III tersebut yaitu koperasi PDAM selaku pihak ketiga untuk mengelola rusun tersebut, namun sampai saat ini belum pernah mengajaknya berkomunikasi.

Hingga saat ini, semua penghuni, baik yang berstatus sewa maupun hak milik rutin membayar PBB. Karena itu, PPRSP hanya mendesak Dinas Tata Kota dan Permukiman (DTKP) karena semua data ada di sana. Ke-50 pemilik rumah telah menuruti permintaan dinas tersebut untuk mengumpulkan fotokopi KK dan KTP dilengkapi materai sampai dua kali.

Menurut Ketua PPRSP sudah berulang kali melayangkan surat ke wali kota dan DTKP, bahkan sampai enam kali pergantian pengurus, tapi tetap tak ada realisasi. Karena tak memiliki sertifikat, mereka mengalami kesulitan untuk menjual rumahnya. Mau tak mau, mereka merelakan rumahnya dihargai rendah karena dijual di bawah tangan, menurut sumber dari Ketua PPRSP sudah banyak pemilikan rusun yang dipindahkan pemilikannya melaui jual beli dibawah tangan tanpa ada pengesahan dari pihak manapun, dengan harga berkisar 25 juta s/d 30 juta untuk satu unit rusun type 27. demikian pula untuk rusun sewa telah banyak dialih sewakan dengan jumlah \pm 25 rusun, dengan harga oper sewa sebesar \pm 25 juta dan Pemkot sendiri tidak melarang bahkan dapat diberikan balik nama dengan biaya 250.000. setiap transaksi, dan berdasarkan kesepakatan dikenakan pungutan wajib untuk pengelolaan paguyuban sebesar 2,5\% disetor ke paguyuban. PBB dibayar oleh semua penghuni baik pemilik maupun penyewa.

Rumah susun bukan sekedar rumah-rumah yang disusun begitu saja, tetapi membutuhkan sistem serta sarana yang harus dapat menunjang agar mekanisme orang-orang di dalamnya bisa befungsi baik. Agar sistem dapat berjalan dengan baik maka diperlukan pengaturanpengaturannya antara lain mengenai : 
1. Kepemilikan rumah susun, sebagaimana diatur dalam pasal 8 Undang-Undang Nomor 16 Tahun 1985 yang menyatakan bahwa, satuan rumah susun dapat dimiliki oleh perorangan atau badan hukum yang memenuhi syarat sebagai pemegang hak serta hak milik atas satuan rumah susun adalah hak milik yang bersifat perorangan atau terpisah.

2. Jaminan hukum bagi pemilik rumah susun, dalam rangka menjamin kepastian hukum dan kepastian hak bagi pemilik satuan rumah susun, maka diperlukan aIat bukti yang kuat, berupa "sertifikat hak milik atas satuan rumah susun" sebagaimana yang diatur dalam Undang-Undang Nomer 16 Tahun 1985 dan Peraturan Pemerintah Nomer 4 Tahun 1988 tentang rumah susun.

3. Mengenai kehidupan para penghuninya diatur dalam Pasal $62-70$ Peraturan Pemerintah Nomer 4 Tahun 1988 tentang rumah susun yang mengatur bahwa perhimpunan penghuni oleh peraturan perundang-undangan diberi kedudukan sebagai badan hukum yang susunan organisasi, hak, dan kewajibannya diatur dalam Anggaran Dasar dan Anggaran Rumah Tangganya, sehingga dapat bertindak keluar dan ke dalam atas nama perhimpunan penghuni dan pemilik dan dengan wewenang yang dimilikinya dapat mewujudkan ketertiban dan ketenteraman dalam lingkungan rumah susun.

4. Perolehan tanah bagi pembangunan rumah susun tersebut. Pada Pasal 7 Undang-Undang Nomer 16 Tahun 1985 menetapkan bahwa rumah susun hanya dapat dibangun di atas tanah yang berstatus hak milik, hak guna bangunan, hak pakai atas tanah negara, dan hak pengelolaan yang diberikan kepada perusahaan pembangunan perumahan yang seluruh modalnya berasal dari pemerintah/pemerintah daerah.

5. Serta mengenai pengaturan-pengaturan yang mengarah pada sistem dan mekanisme rumah susun.

Pemilik rumah susun (50 KK) yang menempati lantai II dan III menurut daftar inventarisasi asset dikenakan pembayaran kekurangan atas nilai unit satuan sarusun yang mereka peroleh sesuai proporsi masing-masing, namun mulai tahun 1992 sampai saat ini belum pernah membayar/dipungut kekurangan tersebut, yang pada awalnya dapat diangsut bulanan. Demikian pula untuk penghuni sewa mereka yang menyewa mulai tahun 1992 sampai tahun 1999 tidak ditarik uang sewa, baru mulai bayar uang sewa tahun 1999. Bahkan kewajiban membayar uang sewa yang sering nunggak tidak diberikan sanksi oleh Pemkot selaku pengelola. Uang sewa semula Rp. 13.500 s/d Rp. 15000 disetor langsung ke Pemda. Untuk tahun 2010 di naikkan menjadi Rp. 40.000 dan Rp. 60.000 per bulan.

\section{Pengembangan konsep konsolidasi tanah dengan pendekatan pembangunan perumahan vertikal untuk menata kembali penguasaan, pemilikan, penggunaan dan pemanfaatan tanah di wilayah perkotaan.}

Menurut Ketua REI Jawa Tengah kebutuhan akan hunian layak bagi warga berpenghasilan menengah ke bawah sudah sangat mendesak di kota Semarang yang kepadattan penduduknya > 13 juta jiwa/km2, namun sampai saat ini belum pernah melaksanakan pembangunan rusun milik di Propinsi Jawa Tengah.

REI pernah mencoba mengkalkulasi rencana pembangunan rusun sederhana untuk menunjang pembangunan seribu tower dengan memanfaatkan tanah asset perumnas di dekat Kantah BPN Kota Semarang, apabila dibangun 20 lantai dengan unit sarusun 600 unit maka akan 
terkaver biaya untuk pengembangan dengan nilai jual $<144$ juta rupiah, namun karena adanya aturan tidak boleh dibangun lebih dari 10 lantai nilai jualnya akan menjadi lebih besar berkisar antara 300 s/d 400 juta/unit rusun. Sehingga menurut Ketua REI Jawa Tengah lebih baik kalau dibangun kodominium/apartemen yang harganya akan menjadi berkisar 500 s/d 600 juta/unit

Pengembangan konsolidasi tanah vertical menurut Ketua REI Jawa Tengah sangat dimungkinkan untuk dikembangkan di Kota Semarang, yaitu dengan melibatkan stake-holders terkait sebagaimana sudah sering dilaksanakan, guna menunjang pendanaan dalam pengembangan pembangunannya. Missal DPU untuk pembangunan infrastukturnya, REI dalam mengupayakan permodalan untuk pembangunan fisiknya, Bapermas dalam pemberdayaan masyarakat untuk meningkatkan penghasilan dan pendapatan penghuni sehingga mampu untuk membayar angsuran. Untuk itu REI Jawa Tengah sedang menyususun proposal untuk pengembangan konsolidasi tanah vertikal untuk menangani daerah kumuh

\section{e) Kota Surabaya}

Kebijakan yang berkaitan dengan pengembangan konsep konsolidasi tanah dengan pendekatan pembangunan perumahan secara vertikal belum ada di Provinsi Jawa Timur. Yang sudah ada adalah Peraturan Daerah Kota Surabaya No 3 tahun 2005 tentang Rumah Susun dan Peraturan Daerah Kota Surabaya No. 2 tahun 2005 tentang Pemakaian Rumah Susun.

Peraturan daerah yang sudah dikeluarkan oleh pemerintah daerah merupakan landasan hukum bagi Pemerintah Daerah untuk membangun Rumah Susun. Dalam Perda Rusun Kota Surabaya diatur mengenai :

- Ketentuan Umum

- Persyaratan Pembangunan Rumah Susun

- Pertelaan Rumah Susun

- Izin Layak Huni

- Pemisahan Satuan Rusun

- Penghunian dan Pengelolaan Rusun

- Penggunaan Rusun

- Pengawasan dan Pembinaan

Dalam Perda Rusun Kota Surabaya tentang Rumah Susun disebutkan bahwa Penggunaan rumah susun terdiri dari rumah susun hunian, rumah susun bukan hunian dan rumah susun penggunaan campuran. Adapun penentuan penggunaan Rusun tersebut harus sudah dinyatakan pada saat mengajukan izin mendirikan bangunan dan selanjutnya dinyatakan dalam Izin Mendirikan bangunan.

Adapun Peraturan Daerah Kota Surabaya No. 2 tahun 2005 tentang Pemakaian Rumah Susun mengatur mengenai Pemanfaatan Rumah Susun, dapat dimanfaatkan oleh setiap penduduk Surabaya yang belum mempunyai rumah tinggal sebagai tempat hunian. Bentuk pemanfaatan dengan cara izin pemakaian rusun dan perjanjian sewa menyewa rumah. Izin pemakaian rumah susun dapat diterbitkan untuk rusun milik Pemda. 
Kebijakan mengenai konsolidasi tanah vertikal harus ada peraturan tersendiri, tidak mengacu kepada UU Rumah Susun, karena kebijakan rumah susun hanya mengatur bagaimana sistim pemilikan hak saja tidak menyebutkan mengenai proses yang harus dilalui untuk membangun rumah susun, sedangkan konsolidasi tanah mempunyai prinsip dasar yaitu :

a) Membangun tanpa menggusur;

b) Kegiatan pembangunan dari rakyat, oleh rakyat dan untuk rakyat;

c) Dilaksanakan berdasarkan kesepakatan bersama (musyawarah);

d) Penyediaan tanah melalui STUP (Sumbangan Tanah Untuk Pembangunan);

e) Pembangunan dibiayai melalui TPBP (Tanah Pengganti Biaya Pelaksanaan);

f) Transparansi;

g) Keadilan;

h) Kepastian hak atas tanah dengan lingkungan yang tertata

Adapun peraturan yang mengatur mengenai konsolidasi tanah yaitu Peraturan Kepala Badan Pertanahan Nasional No. 4 Tahun 1991 tentang Konsolidasi Tanah, tidak dapat digunakan untuk melaksanakan konsolidasi tanah secara vertikal, perlu ada kebijakan baru yang merupakan yang sekaligus mengatur mengenai pelaksanaan konsolidasinya dan pembangunan rumah susun.

Penyediaan lokasi pembangunan Rumah Susun (Rusun) di Surabaya mengacu pada konsep tata ruang kota, sedangkan pemilihan lokasi pembangunan rusun mengacu pada tujuan dibangunnya rusun tersebut, antara lain :

1. Peremajaan pemukiman padat dan kumuh

Pemilihan lokasi didasarkan pada tingkat kepadatan pemukiman di kawasan kumuh

2. Pusat kegiatan ekonomi

Pemilihan lokasi didasarkan pada kawasan pusat kegiatan ekonomi/ industri

3. Kawasan Khusus

Pemilihan lokasi didasarkan pada daerah cepat tumbuh dan daerah pinggiran kota sebagai pendukung kawasan industri sekitarnya

4. Pusat Pendidikan

Pemilihan lokasi didasarkan pada ketersediaan lahan di kawasan pusat pendidikan, dsb.

Dari segi Pendanaan, ada beberapa alternatif pembiayaan :

1. Dana APBN melalui Departemen PU

Diprioritaskan untuk melakukan kegiatan rehabilitasi/revitalisasi suatu kawasan.

2. Dana APBN melalui kementrian Negara Perumahan rakyat

Diarahkan untuk kegiatan pembangunan baru rumah susun

3. Dana APBD Provinsi/Kabupaten/Kota 
Diarahkan untuk melakukan pembangunan baru maupun rehabilitasi rumah susun

4. Pihak III/Swasta

Diarahkan pada kegiatan pembangunan rumah susun pada kawasan strategis.

Pemerintah Provinsi Jawa Timur sangat akomodatif dalam menangani kebutuhan masyarakat untuk perumahan sehingga sudah cukup banyak rumah susun yang dibangun, dan yang berlokasi di kota Surabaya antara lain adalah :

1. Rusunami yang dibangun oleh Perumnas terdapat di kelurahan Menanggal, dikenal dengan nama Rusunami Cipta Menanggal dibangun pada tahun 1987 sebanyak 14 blok s, sekarang dikelola oleh PPRS.

2. Rusunawa Urip Sumoharjo dibangun pada tahun 1975 dan direhabilitasi pada tahun 2004/2005 dengan dana APBD I sebanyak 3 blok.

3. Rusunawa Penjaringansari, dibangun pada tahun 1995 sebanyak 3 blok dan tahun 2004 sebanyak 3 blok dengan dana APBN dan dikelola oleh Pemerintah Kota Surabaya.

4. Rusunawa Sumbo, dibangun pada tahun 1989/1990 sebanyak 10 blok dengan dana APBN dan dikelola oleh Pemkot Surabaya.

5. Rusunawa Waru Gunung, dibangun pada tahun 1996 oleh Perumnas sebanyak 5 twin blok dan dikelola oleh Pemkot Surabaya

6. Rusunawa Siwalankerto dibangun secara bertahap pada tahun 2003/2004 oleh Perumnas sebanyak 2 twin blok, pada tahun 2005 dibangun oleh Pemprov sebanyak 1 twin blok dan pada tahun 2006 dibangun oleh Kementrian Negara Perumahan Rakya sebanyak 2 twin blok dikelola oleh Pemprov Jatim

7. Rusunawa Wonorejo dibangun pada tahun 2004 sebanyak 1 twin blok dan tahun 2006 sebanyak 2 twin blok dengan dana APBN dikelola oleh Pemkot Surabaya.

Kondisi rumah susun sederhana sewa (rusunawa) di Surabaya banyak yang memprihatinkan. Dari enam rusun yang telah dioperasikan, empat di antaranya tampak kumuh seperti di rusunawa Warugunung, Penjaringansari I, Dupak Bangunrejo, dan Sumbo. Sementara dua lainnya, yakni rusunawa Urip Sumoharjo yang baru direnovasi serta Wonorejo yang baru ditempati cukup terkontrol kebersihannya.

Memperhatikan kekumuhan di sebagian besar rusunawa tampak seperti memindahkan kekumuhan dari bantaran kali ke rusunawa. Masalah ini dapat saja terjadi karena kurangnya sosialisasi pemerintah kepada masyarakat penghuni untuk menjaga lingkungannya, oleh karena itu penghuni rusunawa seharusnya dididik agar bisa bertanggung jawab pada lingkungan dengan memelihara kebersihan, kerukunan, dan keharmonisan.

Sampai saat ini belum pernah dilaksanakan konsolidasi tanah vertikal (KTV) di Kota Surabaya, namun pembangunan rumah susun yang mirip konsep KTV pernah dilakukan yaitu :

a) di Kampung Sumbo, kelurahan Simolawang Kecamatan Simokerto, konseptornya adalah Johan Silaas. Daerah ini semula adalah kandang sapi yang dikelola oleh orang madura dan terdapat rumah pegawai Dinas Kebersihan kesemuanya di atas tanah Pemerintah Kota, karena kumuh akhirnya dibangun rusun dengan prioritas orang-orang yang semula 
menetap di daerah tersebut. Jika mereka semula rumahnya besar maka mendapatkan unit lebih banyak dari penghuni lainnya, seperti bapak Kabut yang mendapatkan 9 unit rusun. Rusun yang mulai dibangun pada 14 Desember 1989 dan baru ditempati pada Agustus 1994 itu terdiri atas 603 unit dalam sebelas blok, A-K

b) Di daerah Bangunrejo, semula kampung yang tanahnya berstatus tanah Pemkot, karena kumuh akhirnya dibangun rusun dengan prioritas yang bertempat tinggal, yang rumahnya besar mendapatkan unit lebih banyak seperti Ibu Misni yang mendapatkan 4 unit.

Rusun tersebut di atas mendapatkan fasilitas jalan paving, lampu mercury hanya belum ada fasilitas olah raga, dan dibangun sebelum adanya program 1000 tower.

Walaupun belum pernah dilaksanakan KTV di Kota Surabaya, namun Seksi Pengaturan dan Penataan Pertanahan Kantah Surabaya telah melakukan inventarisasi kondisi fisik wilayah, penguasaan tanah serta aspek sosial lainnya dalam rangka rencana pembangunan rumah susun melalui konsolidasi tanah, yang diarahkan pada lima lokasi di Kota Surabaya, yaitu :

Tabel 45. Rencana lokasi konsolidasi tanah dengan pembangunan vertikal di Kota Surabaya

\begin{tabular}{|c|c|c|c|c|c|c|c|}
\hline No & Lokasi & RTRW & $\begin{array}{c}\text { Penggunaan } \\
\text { Tanah }\end{array}$ & $\begin{array}{l}\text { Status } \\
\text { Tanah }\end{array}$ & $\begin{array}{l}\text { Kepadatan } \\
\text { Penduduk }\end{array}$ & $\begin{array}{c}\text { Pendapatan } \\
\text { /hari }\end{array}$ & $\begin{array}{c}\text { Jaringan } \\
\text { jalan \& } \\
\text { drainase }\end{array}$ \\
\hline 1 & $\begin{array}{lr}\text { Bantaran } & \text { kali } \\
\text { Surabaya Kel. Jagir } \\
\text { \& Ngagelrejo, Kec. } \\
\text { Wonokromo, Kota } \\
\text { Surabaya }\end{array}$ & $\begin{array}{l}\text { Perda No. } \\
\text { 3/2007, untuk } \\
\text { Ruang } \\
\text { Terbuka } \\
\text { Hijau (RTH) }\end{array}$ & $\begin{array}{l}\text { pemukiman } \\
\text { padat, kumuh, } \\
\text { tidak teratur dan } \\
\text { illegal }\end{array}$ & $\begin{array}{l}\text { Tanah } \\
\text { Negara } \\
\text { Penguasaan } \\
\text { Pengairan ) }\end{array}$ & $\begin{array}{l}17.341 \\
\text { jiwa/km2 }\end{array}$ & Rp. 35.000,- & $\begin{array}{l}\text { sempit, dan } \\
\text { tidak } \\
\text { beraturan }\end{array}$ \\
\hline 2 & $\begin{array}{l}\text { Gembong Kel. } \\
\text { Bongkaran, Kec. } \\
\text { Pabean Cantikan, } \\
\text { Kota Surabaya }\end{array}$ & $\begin{array}{l}\text { untuk } \\
\text { perdagangan } \\
\text { dan jasa }\end{array}$ & $\begin{array}{l}\text { Perkampungan } \\
\text { Padat }\end{array}$ & $\begin{array}{lr}\text { Tanah Hak } \\
\text { Milik dan } \\
\text { Hak Guna } \\
\text { Bangunan }\end{array}$ & $\begin{array}{l}10.698 \\
\text { jiwa/km2 }\end{array}$ & Rp. 45.000,- & $\begin{array}{l}\text { Jalan sempit } \\
\text { sudah } \\
\text { dipaving, } \\
\text { drainase: } \\
\text { sempit/tidak } \\
\text { beraturan } \\
\end{array}$ \\
\hline 3 & $\begin{array}{lr}\text { Gubeng-Kalibutuh, } \\
\text { Kel. } & \text { Tembok } \\
\text { Dukuh, } & \text { Kec. } \\
\text { Bubutan } & \end{array}$ & $\begin{array}{l}\text { untuk } \\
\text { perdagangan } \\
\text { dan jasa }\end{array}$ & $\begin{array}{l}\text { Perkampungan } \\
\text { Padat }\end{array}$ & $\begin{array}{l}\text { Tanah Hak } \\
\text { Milik dan } \\
\text { hak Guna } \\
\text { bangunan }\end{array}$ & $\begin{array}{l}22.768 \\
\text { jiwa/km2 }\end{array}$ & Rp. 45.000,- & $\begin{array}{l}\text { Jalan sempit } \\
\text { sudah } \\
\text { diaspal, } \\
\text { drainase: } \\
\text { sempit/tidak } \\
\text { beraturan } \\
\end{array}$ \\
\hline 4 & $\begin{array}{l}\text { Dukuh } \begin{array}{r}\text { Sutorejo, } \\
\text { kec. }\end{array} \text { Mulyorejo, } \\
\text { Kota Surabaya }\end{array}$ & $\begin{array}{l}\text { untuk } \\
\text { perumahan }\end{array}$ & $\begin{array}{l}\text { Pemukiman } \\
\text { padat }\end{array}$ & $\begin{array}{l}\text { Tanah hak } \\
\text { yasan dan } \\
\text { hak Milik }\end{array}$ & $\begin{array}{l}6.002 \\
\text { jiwa/km2 }\end{array}$ & Rp. 40.000,- & $\begin{array}{l}\text { Jalan tanah } \\
\text { sempit, } \\
\text { drainase : } \\
\text { sempit/tidak } \\
\text { beraturan }\end{array}$ \\
\hline 5 & $\begin{array}{ll}\text { Kel. Keputih, } & \text { Kec. } \\
\text { Sukolilo, } & \text { Kota } \\
\text { Surabaya } & \end{array}$ & $\begin{array}{l}\text { untuk } \\
\text { perumahan }\end{array}$ & Pemukiman & $\begin{array}{l}\text { Tanah hak } \\
\text { yasan dan } \\
\text { hak Milik }\end{array}$ & $\begin{array}{l}4.227 \\
\text { jiwa/km2 }\end{array}$ & Rp. 40.000,- & $\begin{array}{l}\text { Jalan tanah } \\
\text { sempit, } \\
\text { drainase : } \\
\text { sempit/tidak } \\
\text { beraturan }\end{array}$ \\
\hline
\end{tabular}

Dari 5 lokasi yang berpotensi untuk dilakukan pembangunan perumahan secara vertikal melalui konsolidasi tanah, lokasi nomor 1 di daerah kelurahan jagir, kecamatan wonokromo walaupun sudah merupakan pemukiman padat namun peruntukan tanahnya menurut RTRW adalah merupakan Ruang Terbuka Hijau sehingga tidak layak untuk dijadikan lokasi Konsolidasi Tanah Vertikal. Sedangkan untuk 4 (empat) lokasi lainnya yang merupakan daerah pemukiman padat dengan fasilitas yang minim dan tidak beraturan berpotensi untuk dijadikan lokasi 
Konsolidasi Tanah secara vertikal dengan penyesuaian RTRW untuk perumahan, perdagangan dan jasa.

\section{f) Kota Yogyakarta}

Kebijakan yang berkaitan dengan pengembangan konsep konsolidasi tanah dengan pendekatan pembangunan perumahan secara vertikal belum ada di provinsi Yogyakarta. Yang sudah dilaksanakan adalah pembangunan rumah susun dengan konsep rumah susun sewa. Rumah susun sederhana milik belum ada karena Peraturan Daerah yang menjabarkan PP No. 4 tahun 1988 tentang Rumah Susun, sampai saat ini belum dimiliki oleh Pemerintah Daerah Provinsi DIY dan Pemerintah Daerah Kabupaten/Kota di wilayah DIY, sehingga landasan hukum yang digunakan bersifat pedoman yang dikeluarkan dalam bentuk keputusan Walikota, antara lain :

- Keputusan Walikota Yogyakarta No.85/2004 tentang Pengelolaan Rumah Susun Milik Pemerintah Kota Yogyakarta

- Surat Keputusan Walikota Yogyakarta No. 369/KD/Tahun 2004 tentang Pembentukan Tim Seleksi Badan Pengelola Rumah Susun Milik Pemerintah pemerintah Kota Yogyakarta

- Surat Keputusan Walikota Yogyakarta No. 377/KD/Tahun 2004 tentang Pembentukan Tim Pembinaan dan Pengawasan Pengelolaan Rumah Susun Milik Pemerintah Kota Yogyakarta.

- Surat Keputusan Walikota Yogyakarta No. 378/KD/Tahun 2004 tentang Pembentukan Tim Seleksi Penghuni Rumah Susun Milik Pemerintah Kota Yogyakarta

- Peraturan walikota Yogyakarta No. 37 tahun 2005 tentang Mekanisme Pengelolaan Keuangan Rumah Susun Milik Pemerintah Kota Yogyakarta

Berdasarkan keputusan tersebut di atas maka dibentuk Tim Pembinaan dan Pengawasan Pengelolaan Rumah Susun milik Pemerintah Kota Yogyakarta, dimana komposisi anggota tim terdiri dari Kimpraswil, Dinas Sosial, Bappeda, Bagian Hukum Pemda, Camat, dsb.

Pembagian tugas dalam pembangunan rumah susun dilaksanakan dalam tiga tahapan:

a) Sosialisasi dilakukan oleh Kimpraswil dan Pemerintah Kota, sedangkan penyiapan lahan oleh Pemerintah Kota.

b) Pembangunan fisik dibiaya oleh Kimpraswil Pusat sedangkan pengawasan di lapangan dilakukan oleh Kimpraswil daerah dan Pemerintah Kota.

c) Pasca pembangunan fisik, yaitu pengelolaan Rumah Susun di lakukan oleh Dinas Sosial.

Dari ke empat Rusunawa yang terdapat di Kota Yogyakarta tersebut, Rusunawa Tegal Panggung telah melakukan kombinasi konsolidasi tanah horizontal dan konsolidasi tanah vertikal. Pada kasus ini, $10 \mathrm{KK}$ awalnya tinggal di lokasi ini yang tanahnya merupakan tanah milik Pemda Kota Yogyakarta, daerah ini berada di pinggiran Kali Code. Ketika rusunawa dibangun mereka mendapatkan prioritas untuk menempati. Kini mereka menjadi penghuni Rusunawa Tegal Panggung dan berada di Lantai 1, dengan status Hak Pakai dan dapat diwariskan. 
Hal ini hanya berlaku untuk ke 10 orang tersebut karena Pemerintah kota telah menetapkan jangka waktu mereka untuk dapat tinggal di rusunawa tersebut. Rusunawa tidak diperuntukan sebagai tempat tinggal seumur hidup bagi tiap penyewa. Jangka waktu 3-6 tahun dianggap maksimal bagi masyarakat untuk dapat menaikkan taraf hidup mereka. Pemerintah hanya memfasilitasi untuk sementara waktu. Setelah 6 tahun tinggal di rusunawa tersebut, masyarakat dianggap telah mapan dan mampu untuk menyewa rumah yang lebih baik lagi.

Besaran uang sewa dari penghuni lama yang mendapat prioritas tersebut berbeda dengan penyewa lainnya, karena mereka hanya dikenakan sewa sebesar Rp 5.000,- per bulan. Sedangkan penyewa lainnya dikenakan tarif berbeda untuk tiap lantai, untuk lantai II dikenakan Rp 185.000,- per bulan, lantai III dikenakan Rp 175.000,- per bulan, dan lantai IV sebesar Rp. 165.000,- per bulan.

Secara umum dapat dikatakan bahwa Konsolidasi Tanah vertikal belum pernah dilaksanakan, namun model pembangunan perumahan yang mendekati konsep Konsolidasi Tanah secara vertikal telah dilaksanakan di 5 (lima) kota sampel.

3. Prosedur Pelaksanaan;

Dari beberapa lokasi sampel yang sudah disebutkan di atas, dapat diambil beberapa model pengembangan konsep Konsolidasi Tanah vertikal di Indonesia, yaitu mengenai :

a) pemilihan lokasi,

- Pembangunan konsolidasi tanah vertikal harus dibangun di lokasi yang sesuai dengan peruntukan dan keserasian lingkungan dengan memperhatikan rencana tata ruang dan tata guna tanah yang ada, di tujukan untuk daerah pemukiman, perdagangan dan jasa.

- lokasinya merupakan pemukiman padat, kumuh, tidak teratur dan illegal

- Penguasaan/Pemilikan tanah : Tanah Negara, Tanah Pemerintah Daerah, Tanah Hak Milik, Tanah HGB, Hak Pengelolaan

- Jalan tanah sempit, drainase : sempit/tidak beraturan

b) Sosialisasi

Sosialisasi sangat penting untuk dilaksanakan dan membutuhkan waktu yang cukup lama untuk menumbuhkan minat masyarakat terhadap konsolidasi tanah karena kultur masyarakat Indonesia yang lebih menyukai landed house, hal ini peneliti jumpai di Kelurahan Kp Aur, yang menolak untuk di konsolidasi tanah secara vertikal, demikian juga yang terjadi di kota cimahi, penduduk setempat lebih menyukai untuk dibeli tanahnya dan mereka mencari lokasi hunian yang baru, ketika dijelaskan keuntungan yang akan mereka peroleh jika tanah mereka di konsolidasi, mereka menghendaki bahwa konsolidasi tanah harus juga disertai dengan memberikan lapangan usaha kepada pesertanya, tidak hanya memperhitungkan keuntungan dari segi kenaikan nilai tanah. 
c) studi kelayakan dan penetapan lokasi

dalam penjajagan lokasi konsolidasi tanah perlu dirumuskan rencana operasional pelaksanaan konsolidsi tanah yang mencakup pembiayaan yang meliputi perkiraan besar biaya, sumber biaya dan waktu pelaksanaan.

Agar pelaksanaan konsolidasi tanah dapat berjalan dengan baik, calon lokasi harus layak dikonsolidasi dengan syarat-syarat kelayakan sebagai berikut :

1). Bagi kepentingan pemilik tanah :

Nilai total asset yang akan didistribusikan kembali kepada pemilik semula harus lebih besar atau sama dengan nilai total asset sebelum konsolidasi.

2). Bagi kepentingan Pemerintah :

Nilai seluruh asset setelah konsolidasi ditambah dengan biaya pembangunan, harus lebih besar atau sama dengan harga seluruh asset sebelum konsolidasi ditambah seluruh biaya pelaksanaan konsolidasi.

3). Bagi kepentingan developer :

Biaya untuk pembangunan konsolidasi harus lebih kecil atau sama dengan harga jual hasil konsolidasi.

Berdasarkan faktor-faktor di atas dan hasil inventarisasi informasi terhadap minat masyarakat, maka lokasi Konsolidasi Tanah Perkotaan ditetapkan sebagai lokasi konsolidasi.

d) perencanaan penataan,

Di dalam merencanakan prasarana dan fasilitas umum di lokasi konsolidasi harus konsisten dengan Rencana Induk Kota atau Rencana Tata Ruang Kota. Dengan dasar tersebut perencanaan dapat disesuaikan dalam hal :

- Rencana penggunaan lahan, misalnya perumahan, perdagangan, industri dan sebagainya;

- Rencana sirkulasi jalan dapat menyesuaikan dengan kebutuhan/sirkulasi jalan di lokasi konsolidasi tersebut;

- Rencana Blok dapat menentukan pembagian wilayah menurut hierarki lingkungan;

- Perencanaan fasilitas harus disesuaikan dengan kebutuhan fasilitas menurut hierarki lingkungan.

- Rencana perumahan didasarkan kepada:

- Pembagian wilayah berdasarkan karakteristik wilayah yang direncanakan;

- Pembentukan unit-unit lingkungan diserasikan dengan kecenderungan perkembangan penduduk atau rencana penduduk yang diproyeksikan.

Kebutuhan prasarana dan fasilitas umum ini akan mempengaruhi besarnya biaya pelaksanaan konsolidasi tanah. 
Sebagai pembanding, pelaksanaan di lapangan tahapan Pembangunan Perumahan rumah susun Pekunden di Semarang :

1) Pra pembangunan rusun :

a. Penyuluhan :

- Penyuluhan tentang rencana pembangunan perumahan melalui konsolidasi tanah secara vertikal, maksud dan tujuan dilaksanakannya pembangunan tersebut.

b.Menghimpun tanggapan masyarakat yang terkena proyek;

- Kesepakatan warga setuju pembangunan rusun apabila system ganti rugi/kompensasi tidak terlalu merugikan warga, dan setelah jadi mendapatkan prioritas pertama untuk menempati;

- selama pembangunan tidak terlantar dan diberi uang untuk pemondokan;

- pembangunan tidak membuat suasana kumuh baru, mempunyai KM/WC sendiri, tempat jemuran dan fasilitas lain;

- pelaksanaan secara manusiawi dan pendekatan;

- fasilitas rusun dilengkapi mushola, aula, taman, tempat bermain dll;penempatan penghuni disesuaikan seperi sebelum dibangun rusun;

- mendapatkan sertipikat hak;

c. Pengukuran tanah dan bangunan rumah dilokasi proyek;

Pengukuran dan penggambaran rumah lama yang akan dibongkar, lengkap dengan ukuran tanah dan bangunan;

d. Sosialisasi dari Pelaksana tentang penghitungan kompensasi asset tanah dan bangunan lama dan kesepakatan warga; antara lain mengenai;

- kompensasi tanah

- bangunan permanen

- bangunan semi permanen

- bangunan non permanen

- biaya kontrak sementara, per KK;

- biaya pembongkaran rumah, untuk setiappemilik;

- uang kompensasi tidak dibayarkan secara tunai, namun pemilik rumah dianggap sudah bayar uang muka dengan uang kompensasi yang diperolehnya secara langsung;

- jumlah kompensasi terkecil dan terbesar

- sertifikat tidak diperoleh secara langsung/memakan waktu.

e. Penandatanganan gambar rumah/tanah dan surat kesepakatan warga lokasi proyek; 
- sebelum dibongkar sudah mendapatkan kompensasi sesuai dengan asset yang dimiliki (luas tanah, bangunan dan fasilitas yang dimiliki);

- sebelum membongkar rumah sudah mendapatkan biaya kontrakminimal satu tahun dan biaya pembongkaran rumah;

- $\quad$ penyewa/pengontrak mendapatkan biaya sendiri;

- tenggang waktu pembongkaran minimal satu bulan.

f.Jadwal pelaksanaan pembongkaran rumah/pindah sementara.

2) Pembangunan rusun :

a. Pemberitahuan gambar bangunan;

- rusun dibangun sekian blok : A, B, C, D, E. terdiri dari sejumlah unit rusun;

- pemanfaatan tiap lantai, misalkan lantai pertama untuk tempat usaha;

- rencana bangunan ukuran standar setiap petak $=7,5 \mathrm{~m}$ x 3,5 $\mathrm{m}=27 \mathrm{~m} 2$ dilengkapi dengan KM/WC, dengan harga sarusun tiap Unit untuk type 54 harga $\mathrm{Rp} 12.000 .000,-$

b. Penyuluhan tata cara tinggal di rumah susun;

- menjaga kebersihan dan ketertiban;

- mengutamakan kerukunan dan kelompok karena hidup bersama;

- pemakaian KM/WC, membuang sampah, menjemur pakaian dsb;

- perabot lama/rusak tidak dibawa ke rusun;

c. Pembagian rumah kepada warga yang berhak;

- pembagian rumah disesuaikan dengan urutan prioritas;

- untuk pemilik rumah diutamakan di lantai II

- warga yang punya tempat usaha akan mendapat prioritas utama;

- pembagian rumah dan pengelolaan diserahkan kepada wkil warga;

- pengontrak diberi kesempatan untuk memiliki dengan angsuran.sewa;

- warga yang mendapatkan kompensasi mendapatkan unit rusun di lantai II;

- sisanya dapat dijual.

\section{3). Pengelolaan Rumah Susun}

Melalui Pembentukan Paguyuban Penghuni Rusun :

- Menetapkan program kerja;

- Menyusun peraturan tata-tertib penghuni rusun;

- Menyusun AD/ART; 
e) administrasi pertanahannya,

Prosedur dan dasar hukum penyelesaian administrasi Hak Atas Tanah dengan sertifikasi pesil-persil baru dalam pelaksanaan Konsolidasi Tanah, pada umumnya ditempuh dengan prosedur sebagai berikut :

1).Pelepasan Hak Atas Tanah obyek konsolidasi tanah menjadi tanah negara (sementara) untuk memudahkan proses penataan dan pemberian hak;

2).Penegasan Obyek Konsolidasi Tanah oleh Kepala Kantor Wilayah Badan Pertanahan Nasional Provinsi;

3).Penerbitan SK. Hak milik dalam rangka Konsolidasi Tanah Perkotaan oleh Kepala Kantor Pertanahan secara kolektif;

4).Pemberian Hak Pakai dalam Rangka Konsolidasi Tanah Perkotaan ditetapkan oleh Kepala Kantor Wilayah Badan Pertanahan Nasional Provinsi untuk tanah fasilitas umum/sosial;

5).Penerbitan sertipikat setelah dipenuhi persyaratan sesuai peraturan yang berlaku.

f) pembangunan fisik,

Konsep dasar pembangunan dengan Konsolidasi Tanah Perkotaan, adalah dari dan untuk masyarakat (pemilik lahan) yang melibatkan partisipasi aktif masyarakat sehingga keuntungan seharusnya diperoleh oleh kedua belah pihak yaitu Pemerintah dan Pemilik Tanah asal dalam proyek Konsolidasi Tanah Perkotaan;

Konsolidasi tanah merupakan kegiatan pembangunan terpadu yang melibatkan berbagai instansi, dan menyangkut banyak aspek. Sesuai dengan situasi dan kondisi di Indonesia, di mana dalam penataan/pembangunan suatu wilayah harus melibatkan beberapa instansi terkait, maka pada tahap persiapan perlu dilakukan pendekatan dengan instansi-instansi terkait, tokoh masyarakat dan para pemilik tanah peserta konsolidasi untuk memperoleh dukungan dan persamaan persepsi agar diperoleh keterpaduan gerak dan langkah dalam pembangunan tersebut. Demikian juga dalam merencanakan biaya pembangunan fisik harus sudah direncanakan dari sejak awal pelaksanaan. Sehingga dengan perencanaan yang lebih matang dan adanya dukungan biaya yang cukup diharapkan akan tercapai hasil yang lebih baik.

g) pembiayaan konsolidasi tanah

Pembiayaan Konsolidasi Tanah Perkotaan di lokasi penelitian dibiayai dengan anggaran APBN dan APBD Tk. I serta APBD Tk. II dan swadaya masyarakat peserta konsolidasi tanah, yang dalam pelaksanaannya hanya sampai pada batas penataan dan sertipikasi tanah saja. Sedangkan biaya pembangunan dalam pelaksanaan konsolidasi tanah vertikal sebaiknya terdiri dari beberapa kebutuhan antara lain :

1). biaya administrasi perencanaan konsolidasi tanah;

2). biaya ganti rugi bangunan, ganti rugi tanaman berharga, tanah dan ganti kerugian lainnya yang ditimbulkan;

3). biaya pembangunan konstruksi fisik; 
4). biaya penampungan sementara selama pembangunan fisik;

5). biaya pengelolaan dan pengawasan (monitoring)

Sedangkan biaya pembangunan konsolidasi tanah dapat diperoleh dari :

1). penjualan sebagian hasil pembangunan konsolidasi tanah secara vertikal yang dapat dijual sebagai biaya pembangunan;

2). pemodal/pengembang;

3). subsidi dari Pemerintah Pusat/Pemerintah Daerah;

4). pinjaman dari Bank.

\section{Penyelesaian Hak Atas Tanah}

Dari sejumlah data yang diperoleh peneliti mengenai pelaksanaan pembangunan perumahan yang "mirip" dengan konsep Konsolidasi tanah Vertikal, pada umumnya merupakan tanah Pemerintah Daerah yang diokupasi oleh masyarakat selama bertahuntahun sehingga haknya tetap dipegang oleh pemerintah Daerah, kecuali untuk Rusun Pekunden di Kota Semarang dijanjikan mereka akan memperoleh sertipikat Hak Milik atas satuan rumah susun namun sampai saat ini belum terlaksana walaupun sudah dibangun dan ditempati selama kurang lebih 20 tahun.

Dalam konsolidasi tanah horizontal, penyelesaian Hak Atas tanah dilaksanakan:

- Pelepasan HAT sebelum konsolidasi untuk mendapatkan kembali HAT setelah KT

- Kesepakatan peserta KT atas disain ,letak,luas bidang tanah setelah konsolidasi, serta STUP dan TPBP

- Penerbitan keputusan pemberian HAT setelah konsolidasi secara kolektif

- Penerbitan sertipikat HAT masing-masing peserta KT

Penyelesaian hak atas tanah untuk pembangunan rusun perlu dilaksanakan dengan mengacu pada UU 16/1985 tentang Rumah Susun, maka Rumah susun hanya dapat dibangun di atas tanah hak milik, hak guna bangunan, hak pakai atas tanah Negara atau hak pengelolaan sesuai dengan peraturan perundang-undangan yang berlaku.

Penyelenggaraan pembangunan yang membangun rumah susun di atas tanah yang dikuasai dengan hak pengelolaan, wajib menyelesaikan status hak guna bangunan di atas hak pengelolaan tersebut sesuai dengan peraturan perundang-undangan yang berlaku sebelum menjual satuan rumah susun yang bersangkutan.

Penyelenggaraan pembangunan wajib memisahkan rumah susun atas satuan dan bagian-bersama dalam bentuk gambar dan uraian yang disahkan oleh instansi yang berwenang sesuai dengan peraturan perundang-undangan yang berlaku yang memberi kejelasan atas :

a. batas satuan yang dapat dipergunakan-secara terpisah untuk perseorangan;

b. batas dan uraian atas bagian-bersama dan benda-bersama yang menjadi haknya masing-masing satuan; 
c. batas dan uraian tanah-bersama dan besarnya bagian yang menjadi haknya masing-masing satuan.

d. Satuan rumah susun dimiliki oleh perseorangan atau badan hukum yang memenuhi syarat sebagai pemegang hak atas tanah.

e. Hak milik atas satuan rumah susun adalah hak milik atas satuan yang bersifat perseorangan dan terpisah.

f. Hak milik atas satuan rumah susun meliputi juga hak atas bagian-bersama, benda-bersama, dan tanah-bersama, yang semuanya merupakan satu-kesatuan yang tidak terpisahkan dengan satuan yang bersangkutan.

g. Hak atas bagian-bersama, benda-bersama, dan hak atas tanah bersama didasarkan atas luas atau nilai satuan rumah susun yang bersangkutan pada waktu satuan tersebut diperoleh pemiliknya yang pertama.

h. Sebagai tanda bukti hak milik atas satuan rumah susun diterbitkan sertifikat hak milik atas satuan rumah susun.

i. Sertifikat hak milik atas satuan rumah susun terdiri atas :

- Salinan Buku Tanah dan Surat Ukur atas Hak Tanah Bersama menurut ketentuan Peraturan Pemerintah sebagaimana dimaksud dalam Pasal 19 Undang-undang Nomor 5 Tahun 1960;

- Gambar denah tingkat rumah susun yang bersangkutan, yang menunjukkan satuan rumah susun yang dimiliki;

- Pertelaan mengenai besarnya bagian hak atas bagian-bersama, bendabersama dan tanah-bersama yang bersangkutan;

kesemuanya merupakan satu kesatuan yang tidak terpisahkan.

j. Hak milik atas satuan rumah susun dapat beralih dengan cara pewarisan atau dengan cara pemindahan hak sesuai dengan ketentuan hukum yang berlaku.

k. Pemindahan hak dilakukan dengan akta Pejabat Pembuat Akta Tanah dan didaftarkan pada Kantor Agraria Kabupaten atau Kotamadya yang bersangkutan menurut Peraturan Pemerintah sebagaimana dimaksud dalam Pasal 19 Undangundang Nomor 5 Tahun 1960.

1. Pemerintah memberikan kemudahan bagi golongan masyarakat yang berpenghasilan rendah untuk memperoleh dan memiliki satuan rumah susun dan pelaksanaannya diatur dengan Peraturan Pemerintah.

Mengacu pada ketentuan UU Rumah Susun No. 16 tahun 1985 dan Perkaban No.4 tahun 1991 tentang Konsolidasi Tanah Perkotaan, maka penyelesaian hak atas tanah untuk konsolidasi tanah vertikal harus memuat :

- Kesepakatan peserta KT dengan penyelenggara pembangunan atas disain ,letak,luas unit rumah susun beserta hak bersama atas benda, bagian dan tanah bersama setelah konsolidasi

- Pelepasan HAT sebelum konsolidasi untuk mendapatkan unit2 hak milik atas satuan rumah susun setelah KT 
- Penerbitan sertipikat HAT

- Penerbitan pertelaan dan akta pemisahan

- Penerbitan sertipikat HM Sarusun

5. Subyek dan Obyek

Pendataan subyek/dan obyek di lokasi yang direncanakan merupakan faktor penting dalam pelaksanaan konsolidasi tanah. Pendataan tersebut meliputi :

1). Nama dan alamat subyek

2). Luas persil demi persil;

3). Luas selokan/saluran yang sudah ada;

4). Luas jalan yang sudah ada dan;

5). Luas prasarana lain yang ada di lokasi tersebut.

Disamping luas areal konsolidasi tanah, perlu batas-batas areal yang jelas, karena dengan batas yang kurang jelas akan menimbulkan masalah-masalah yang rumit baik dalam kalkulasi persil demi persil maupun pengukurannya di lapangan. Batas areal yang jelas ini penting untuk suatu perencanaan yang utuh.

Semua hak dan kepentingan yang terdapat di areal konsolidasi tanah perlu diinventarisir antara lain :

1). Meliputi hak atas barang tak bergerak;

2). Hak milik;

3). Hak sewa dll;

4). Informasi lokasi;

5). Kategori tanah;

6). Luas tanahnya;

7). Tanggal pendaftarannya;

8). Latar belakang;

9). Alamat pemilik/penyewa;

10). Keterangan batas;

11). Satuan jalan;

12). Perbatasan persil dan;

13). Nomor persil semenjak tanah dimiliki.

14). Jika tanah yang dalam keadaan sengketa maka kedua belah pihak harus menyatakan persetujuannya dan ikut bersedia dalam Konsolidasi Tanah.

Hal ini dilakukan untuk mengetahui data-data luas khususnya di dalam pelaksanaan konsolidasi tanah sebagai dasar untuk membuat perencanaan pelaksanaan konsolidasi tanah. Bangunan, tanaman berharga dan lannya perlu dinilai di dalam 
memperhitungkan nilai asset maupun besarnya ganti rugi yang mungkin ditimbulkan. Hal ini perlu dalam rangka memperhitungkan besarnya biaya perencanaan dan memperkirakan berapa besarnya biaya ganti rugi yang mungkin akan terjadi. Besarnya ganti rugi ini akan mempengaruhi besarnya biaya secara keseluruhan.

6. Hak dan Kewajiban peserta konsolidasi

Konsolidasi Tanah adalah kebijaksanaan pertanahan mengenai penataan kembali penguasaan dan penggunaan tanah serta usaha pengadaan tanah untuk kepentingan pembangunan, untuk meningkatkan kualitas lingkungan dan pemeliharaan sumberdaya alam dengan melibatkan partisipasi aktif masyarakat. Oleh karena itu dalam pelaksanaan Konsolidasi Tanah Perkotaan ini perlu adanya kejelasan hak dan kewajiban peserta konsolidasi tanah.

Dari hasil pengamatan di lokasi penelitian diperoleh hasil bahwa peserta konsolidasi tanah mempunyai hak dan kewajiban sebagai berikut :

a. Hak peserta konsolidasi tanah

1). Menerima kembali hasil konsolidasi tanah sesudah penataan;

2). Menerima Sertipikat Hak hasil konsolidasi tanah sesudah penataan;

b. Kewajiban peserta konsolidasi tanah

1). Menyerahkah/melepaskan bidang tanah dalam rangka penataan;

2). Menyerahkan hak atas tanah dalam rangka penataan;

Hak dan kewajiban peserta Konsolidasi Tanah Perkotaan perlu lebih diperjelas secara lebih rinci, misalnya :

a. Hak peserta konsolidasi tanah

1). Memahami konsep, mengetahui rencana dan pelaksanaan konsolidasi tanah;

2). Memperoleh informasi yang jelas dan terbuka mengenai rencana, proses dan pelaksanaan konsolidasi tanah;

3). Memperoleh informasi yang jelas dan terbuka mengenai besarnya biaya pembangunan dalam pelaksanaan konsolidasi tanah;

4). Memberikan pendapat dan peranserta dalam proses pelaksanaan konsolidasi tanah;

5). Memperoleh hak-hak yang telah disepakati setelah penataan;

6). Tidak dibebani pungutan/biaya lainnya di luar kesepakatan.

b. Kewajiban peserta konsolidasi tanah

1). Menyerahkan tanahnya dalam rangka pelaksanaan konsolidasi tanah;

2). Memelihara, memanfaatkan dan menggunakan hasil konsolidasi tanah sesuai peruntukannya; 
3). Mentaati aturan pelaksanaan konsolidasi tanah sesuai rencana yang telah disepakati.

4). Dan sebagainya.

7. Organisasi penyelenggara

Pada umunya inisiatif penyelenggaraan konsolidasi tanah di daerah perkotaan berbagai negara berasal dari :

a. Pemerintah, dalam hal ini bisa satu Departemen atau Lembaga Pemerintah yang mengelola bidang pertanahan, bisa Kepala Pemerintahan Daerah Tingkat I (Gubernur KDH Tk.I) dan bisa pula Kepala Pemerintahan Daerah Tingkat II (Bupati/Walikota) baik atas pertimbangan politis maupun atas pertimbangan administratif.

Konsolidasi tanah dilaksanakan dalam rangka merehabilitir daerah-daerah perkotaan yang sering terkena bencana banjir dan/atau bencana lainnya, memperbaiki lingkungan pemukiman yang kumuh sekaligus dalam rangka mengurangi kepadatan arus lalu lintas, namun tetap sesuai/konsisten dengan rencana tata kota (City Planning) yang ada.

b. Konsep rencana proyek dibuat oleh aparat Pemerintahan yang bersangkutan, kemudian dirundingkan dengan pemuka-pemuka, organisasi kemasyarakatan dan para pemilik tanahnya; dan penyelenggaraannya baru dapat dijalankan setelah mendapat persetujuan dari Pejabat yang lebih tinggi.

Masyarakat pemilik tanah sendiri, baik secara perseorangan maupun yang berhimpun dalam suatu perkumpulan (Assosiasi), yang atas kesadaran sendiri berkeinginan agar lingkungan hidupnya dapat menjadi lebih baik, persil-persil tanah mereka dapat menjadi teratur bentuknya, lebih efektif pemanfaatannya serta nilai ekonomis tanahnya dapat lebih ditingkatkan. Dengan bantuan tenaga teknis dari Pemerintah, disusun konsep rencana proyeknya, kemudian ditawarkan kepada para pemilik tanah baik melalui ajakan langsung secara berantai maupun melalui rapatrapat lokal. Lain dari itu, tidak tertutup pula kemungkinan bagi suatu Perusahaan Umum untuk menjadi inisiator, bahkan mereka termasuk Pemerintah sendiri dapat menjadi peserta konsolidasi.

c. penyelenggaraan konsolidasi tanah dengan pendekatan pembangunan vertkal dikaitkan dengan UU 16/1985 tentang Rumah Susun, pembangunan rumah susun disesuaikan dengan keperluan dan kemampuan masyarakat, terutama yang berpenghasilan rendah, baik mengenai jumlah, kualitas bangunan, lingkungan maupun persyaratan dan tata cara untuk memperolehnya, dan dalam rangka pemberian kesempatan berusaha, Pemerintah memberikan kesempatan kepada Badan Usaha Milik Negara atau Daerah, Koperasi dan Badan Usaha Swasta yang bergerak dalam bidang itu, serta Swadaya Masyarakat untuk membangun rumah susun dengan berpedoman pada asas pemerataan dan keterjangkauan.

8. Pengendalian dan pengelolaan konsolidasi tanah vertikal

Permasalahan yang muncul dalam pelaksanaan konsolidasi tanah perkotaan di beberapa lokasi sampel penelitian antara lain disebabkan karena pelaksanaan konsolidasi 
tanah tersebut hanya sebatas pelaksanaan proyek dengan target penataan dan sertipikasi tanah saja, sehingga pengendalian dan pengelolaan sesudah proyek menjadi tidak jelas, untuk itu diperlukan :

1). Pengelolaan dan pengendalian pelaksanaan konsolidasi tanah mulai tahap Rencana Pelaksanaan sampai dengan Konstruksi dilakukan oleh Penanggung Jawab Konsolidasi Tanah;

2). Pengelolaan dan pengendalian berpedoman kepada Rencana Umum Pelaksanaan Konsolidasi Tanah, dan Rencana Penataan yang telah disepakati oleh peserta Konsolidasi Tanah dan disetujui oleh Penanggung Jawab;

3). Penanggung Jawab Konsolidasi Tanah bertanggung jawab kepada peserta Konsolidasi Tanah dan melaporkan hasil kegiatannya;

4). Pengelolaan dan pengendalian Konsolidasi Tanah perlu diatur lebih lanjut dengan Peraturan Perundang-undangan.

B. Apakah peraturan perundang-undangan yang ada dapat mendukung pelaksanaan konsolidasi tanah secara vertikal ?

Peraturan yang berlaku saat ini belum mendukung sepenuhnya pelaksanaan pembangunan rumah susun melalui konsolidasi tanah secara vertikal, demikian juga Perkaban No. 4 tahun 1991 tentang Konsolidasi Tanah Perkotaan tidak bisa diterapkan secara murni karena Perkaban tersebut lebih tepat untuk pelaksanaan konsolidasi tanah secara horizontal, sehingga ada hal-hal yang tidak bisa digunakan dalam pembangunan konsolidasi tanah vertikal.

Dalam Perkaban No. 4 tahun 1991 memuat esensi penting dalam konsolidasi tanah yaitu penataan kembali penguasaan dan penggunaan tanah serta usaha pengadaan tanah untuk kepentingan pembangunan, untuk meningkatkan kualitas lingkungan dan pemeliharaan sumber daya alam dengan melibatkan partisipasi aktif masyarakat. Selain itu adanya Sumbangan tanah untuk pembangunan adalah bagian dari obyek Konsolidasi Tanah yang disediakan untuk pembangunan prasarana jalan dan fasilitas umum lainnya, serta untuk Tanah Pengganti biaya Pelaksanaan.

Sedangkan dalam UU No. 16 tahun 1985 tentang Rumah Susun, dikenal adanya Nilai perbandingan proporsional adalah angka yang menunjukkan perbandingan antara satuan rumah susun terhadap hak atas bagian bersama, benda bersama, dan tanah bersama, dihitung berdasarkan luas atau nilai satuan rumah susun yang bersangkutan terhadap jumlah luas bangunan atau nilai rumah susun secara keseluruhan pada waktu penyelenggara pembangunan untuk pertama kali memperhitungkan biaya pembangunannya secara keseluruhan untuk menentukan harga jualnya.

Oleh karena itu perlu ada peraturan yang secara khusus mengatur mengenai konsolidasi tanah secara vertikal dengan mengkombinasikan ketentuan yang merupakan azas prinsip dalam konsolidasi sesuai dengan Perkaban No.4 tahun 1991 dengan ketentuan UURS yang mengatur sistem pembangunan dan pemilikan rumah susun. 


\section{BAB VI \\ KESIMPULAN DAN SARAN}

\section{A. KESIMPULAN}

1. Kepadatan penduduk di sejumlah kota besar di Indonesia semakin meningkat dari tahun ke tahun sedangkan kesediaan tanah diperkotaan terbatas dan kondisi ekonomi masyarakat yang rendah, sehingga tanpa penataan lingkungan pemukiman akan mengakibatkan timbulnya kantong-kantong kumuh (slum area) di wilayah perkotaan tersebut. Oleh karena itu sudah saatnya untuk melakukan pembangunan perumahan yang memanfaatkan ruang ke atas secara vertikal untuk memenuhi kebutuhan perumahan diperkotaan dan optimalisasi penggunaan dan pemanfaatan tanah. Dengan konsolidasi tanah maka penggusuran dapat dihindarkan karena prinsip dasarnya adalah melibatkan partisipasi masyarakat dalam membangun dan menerima hasil pembangunan. Konsolidasi Tanah sebagai salah satu konsep penataan dan pembangunan lingkungan pemukiman mempunyai beberapa manfaat, yaitu menata dan mengatur kembali daerah yang tidak teratur menjadi teratur dengan dilengkapi prasarana dan fasilitas lingkungan yang memadai sesuai keperluan.

Dari 8 lokasi sampel penelitian, belum satupun yang sudah melaksanakan konsolidasi tanah secara vertikal, namun ditemukan model pembangunan rumah susun yang konsepnya mendekati (mirip) dengan konsep konsolidasi tanah secara vertikal yaitu di 4 (empat) lokasi penelitian antara lain di Kota Semarang, Kota Yogyakarta, Kota Surabaya dan Kota Palembang. Ke"mirip"an dengan konsep konsolidasi tanah terletak pada beberapa hal, antara lain penghuni asal mendapatkan prioritas untuk menempati rumah susun, kemudian pembangunan rusun diawali dengan kesepakatan Pemkot dan masyarakat penghuni membuat perjanjian bahwa tanah dan bangunan masyarakat yang berdomisili di lingkungan tersebut dinilai sesuai dengan kondisi existing yang ada. Masing-masing diberikan kompensasi sesuai dengan nilai tanah dan bangunan tersebut, namun tidak diberikaan dalam bentuk uang tetapi sebagai uang muka untuk mendapatkan unit satuan atas rumah susun yang akan dibangun sesuai proporsi nilai tanah yang sudah disepakati oleh seluruh penghuni yang ada.

Selain itu, dalam pembangunan rumah susun untuk peremajaan kota di Palembang dilaksanakan di atas tanah negara yang sudah dihuni selama lebih dari 30 tahun, setelah ditata ulang melalui peremajaan kota sebanyak 47 keluarga masyarakat mendapatkan hak atas tanahnya dan pembangunan rusun Milik 24 dan 26 Ilir Palembang yang semula merupakan daerah pemukiman padat korban kebakaran dan dihuni oleh masyarakat dengan melebihi kapasitas yang menyebabkan kekumuhan. Menpera dan Pemerintah Kota Palembang tahun 1998 berinisiatif untuk membangun kawasan sersebut menjadi rumah susun milik untuk memenuhi kebutuhan masyarakat korban kebakaran dan masyarakat sekitarnya yang waktu itu cukup padat dan kumuh, diharapkan dapat ditampung dalam rumah susun tersebut. 
Dari beberapa lokasi sampel yang sudah disebutkan di atas, dapat diambil beberapa hal yang dapat diambil sebagai rujukan dalam pengembangan konsep Konsolidasi Tanah vertikal di Indonesia, yaitu mengenai landasan hukum, prosedur pelaksanaan, penyelesaian hak atas tanah, subyek dan obyek, hak dan kewajiban peserta konsolidasi, organisasi penyelenggara serta pengendalian dan pengelolaan konsolidasi tanah vertikal.

2. Peraturan yang berlaku saat ini belum mendukung sepenuhnya pelaksanaan pembangunan rumah susun melalui konsolidasi tanah secara vertikal, baik UU tentang Rumah Susun demikian juga Perkaban No. 4 tahun 1991 tentang Konsolidasi Tanah Perkotaan tidak bisa diterapkan secara murni karena Perkaban tersebut lebih tepat untuk pelaksanaan konsolidasi tanah secara horizontal, sehingga ada hal-hal yang tidak bisa digunakan dalam pembangunan konsolidasi tanah vertikal.

Dalam Perkaban No. 4 tahun 1991 memuat esensi penting dalam konsolidasi tanah yaitu penataan kembali penguasaan dan penggunaan tanah serta usaha pengadaan tanah untuk kepentingan pembangunan, untuk meningkatkan kualitas lingkungan dan pemeliharaan sumber daya alam dengan melibatkan partisipasi aktif masyarakat. Selain itu adanya Sumbangan tanah untuk pembangunan adalah bagian dari obyek Konsolidasi Tanah yang disediakan untuk pembangunan prasarana jalan dan fasilitas umum lainnya, serta untuk Tanah Pengganti biaya Pelaksanaan.

Sedangkan dalam UU No. 16 tahun 1985 tentang Rumah Susun, dikenal adanya Nilai perbandingan proporsional adalah angka yang menunjukkan perbandingan antara satuan rumah susun terhadap hak atas bagian bersama, benda bersama, dan tanah bersama, dihitung berdasarkan luas atau nilai satuan rumah susun yang bersangkutan terhadap jumlah luas bangunan atau nilai rumah susun secara keseluruhan pada waktu penyelenggara pembangunan untuk pertama kali memperhitungkan biaya pembangunannya secara keseluruhan untuk menentukan harga jualnya.

Oleh karena itu perlu ada peraturan yang secara khusus mengatur mengenai konsolidasi tanah secara vertikal dengan mengkombinasikan ketentuan yang merupakan azas prinsip dalam konsolidasi sesuai dengan Perkaban No.4 tahun 1991 dengan ketentuan UURS yang mengatur sistem pembangunan dan pemilikan rumah susun.

\section{B. SARAN}

1. Bahwa konsolidasi tanah vertikal merupakan alternatif paling efektif untuk diterapkan di kota besar terutama di wilayah yang tingkat kepadatannya sangat tinggi, penguasaan/pemilikan tanah sempit, tidak teratur, kumuh dengan kondisi ekonomi masyarakat yang rendah.Sehubungan dengan hal itu, disarankan pada masa mendatang konsolidasi tanah di daerah tersebut dilakukan dengan metode wajib (compulsory method). Sehingga ada dua metode yang dapat dicantumkan dalam peraturan konsolidasi yaitu metode wajib (voluntary method) dan metode suka rela (voluntary method). 
2. Bahwa untuk mendukung pelaksanaan konsolidasi tanah vertikal maka perlu diatur dalam suatu kebijakan khusus yang mengatur hal tersebut, tidak hanya berdasarkan pada UURS maupun Perkaban No 4 tahun 1991.

3. Rekomendasi substansi konsolidasi tanah vertikal dapat diatur melalui revisi Perkaban No. 4 tahun 1991 atau ditingkatkan menjadi UU atau PP. 


\section{DAFTAR PUSTAKA}

\section{A. Buku}

1. Menteri Negara Perumahan Rakyat Republik Indonesia, Keynote Speech Seminar Pengembangan Rumah Susun, Prospek, Tantangan Dan Permasalahannya, Jakarta, 2007.

2. Maria SW Sumardjono. Kebijakan Pertanahan : Antara Regulasi dan Implementasi, Kompas, 2006.

3. Arie S. Hutagalung, Kondominium dan Permasalahannya, Badan Penerbit FH UI, Jakarta, 2007.

4. Boedi Harsono, Hukum Agraria Indonesia, Sejarah Pembentukan Undang-undang Pokok Agraria, Isi dan Pelaksanaannya, Djambatan, Jakarta, 2005.

5. Doebele, W.A. (ed). (1982). Land readjustment: a different approach to financing urbanization. Massachusets: D.C. Heath and Company.

6. Harun, I.B. (1998). The prospect of land consolidation as urban development method in Indonesia. Disertasi Doktoral. Tokyo: Dept. of Urban Engineering, University of Tokyo.

7. Laporan Penelitian Proyek-Proyek Konsolidasi Tanah Perkotaan di Daerah, Puslitbang BPN, Jakarta 1991/1992

8. Lokakarya Konsolidasi Tanah se Kalimantan di Pontianak,Maret 1992, Direktorat Pengaturan Penguasaan Tanah, BPN, 1993

9. Laporan Penelitian Peranan Pemerintah Daerah Dalam Pelaksanaan Konsolidasi Tanah Perkotaan, Puslitbang BPN, Jakarta 1993/1994

10. Kebijakan Publik, Said Zainal Abidin, Ph.D, Jakarta 2002.

11. Analisis Kepemilikan Hak Atas Tanah Satuan Rumah Susun di Dalam Kerangka Hukum Benda. M. Rizal Alif, SH.,MN, 2009. Bandung. Penerbit Nuansa Aulia.

12. Yudhi, Setiawan. Instrumen Hukum Campuran (gemeenschapelijkrecht) dalam Konsolidasi Tanah. PT. Raja Cirafindo Persada, Jakarta, 2009.

\section{B. Website}

13. http//www.apeksi.or.id. 


\section{Peraturan Perundangan}

14. Undang-Undang Dasar Negara Republik Indonesia 194.5

15. Undang-Undang Nomor 5 Tahun 1960 tentang Peraturan Dasar Pokok-pokok Agraria.

16. Undang-Undang Nomor 16 Tahun 1985 tentang Rumah Susun

17. Undang-Undang Nomor 4 Tahun 1992 tentang Perumahan dan Permukiman.

18. Undang-Undang Republik Indonesia Nomor 24 Tahun 1992, tentang Penataan Ruang.

19. Undang-Undang Nomor 4 Tahun 1996 tentang Hak Tanggungan

20. Undang-Undang Nomor 28 Tahun 2002 tentang Bangunan Gedung

21. Undang-Undang Nomor 32 tahun 2004 tentang Pemerintahan Daerah.

22. Peraturan Pemerintah Republik Indonesia Nomor 4 Tahun 1988 tentang Rumah Susun

23. Peraturan Pemerintah Republik Indonesia Nomor 16 Tahun 2004, tentang Penatagunaan Tanah.

24. Peraturan Presiden Nomor 10 Tahun 2006 tentang Badan Pertanahan Nasional

25. Keputusan Presiden Nomor 22 tahun 2006 tentang Tim Koordinasi Percepatan Pembangunan Rumah Susun di Kawasan Perkotaan

26. Peraturan KaBPN Nomor 4 Tahun 1991 tentang Konsolidasi Tanah. 